\title{
Revisiting the Economic Community of West African States:
}

\section{A Socio-Legal Analysis}

\author{
Olabisi Delebayo Akinkugbe \\ Thesis submitted to the \\ Faculty of Graduate and Postdoctoral Studies \\ in partial fulfillment of the requirements \\ for the Doctorate in Philosophy $(\mathrm{PhD})$ degree in Law
}

\author{
Graduate Studies in Law \\ Faculty of Law \\ University of Ottawa
}

(C) Olabisi Delebayo Akinkugbe, Ottawa, Canada, 2017 


\begin{abstract}
Recent years have seen a growing scholarly interest in the conditions of emergence of regional trade agreements in Africa. These analyses have advanced our knowledge on a range of technical issues, from specific institutional transformation of regional economic communities such as the Economic Community of West African States (ECOWAS) to broad legal issues relating to the provisions of the regional trade agreements. Most literature on ECOWAS is, however, informed by legal formalism that interprets the text of the treaties strictly and without context, leading to a dominant interpretation of failure.
\end{abstract}

By contrast, this thesis adopts a socio-legal approach and argues that the dominant narrative's conceptualization of ECOWAS is narrow and under-representative of the broader contexts of the social relations in which ECOWAS Treaties and their implementation are embedded. The failure narratives do not adequately account for the complex social, historical, and political factors that shape the implementation of the ECOWAS Treaties.

By combining socio-legal approach with insights from International Relations on new regionalism, the thesis reconceptualizes regionalism in ECOWAS as a social phenomenon. It approaches the ECOWAS Treaties as embedded in the socio-political relations, power struggles, and social structures of the Community. To differentiate the thesis from existing research on ECOWAS, it incorporates national, regional, and international factors in illuminating the complex and multifaceted confluence of circumstances that shape the implementation of the ECOWAS Treaties. Simultaneously, 
the thesis enriches our understanding of the theories of new regionalism by deepening the analysis in relation to ECOWAS. Seen from this perspective, the thesis concludes that ECOWAS cannot be regarded as a straightforward failure and that its achievements are not to be found primarily in economic integration but in other socio-political factors that it enabled. Finally, the analysis opens new opportunities for future normative analyses that interrogate the effectiveness of ECOWAS by taking into account the socio-political $\begin{array}{llll}\text { contexts in } & \text { which is embedded. }\end{array}$ 


\section{TABLE OF CONTENTS}

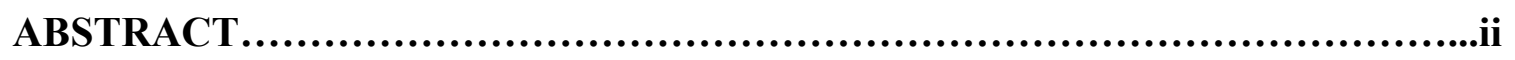

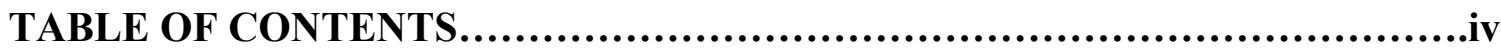

ACKNOWLEDGEMENTS .........................................................vii

CHAPTER 1: THE DILEMMA OF LAW, POLITICS, AND THE SOCIAL IN

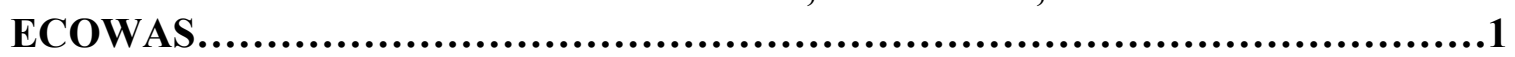

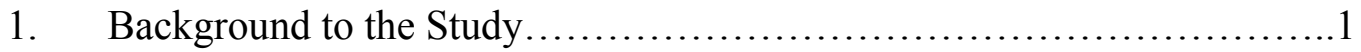

1.2. Waves of Regionalism in West Africa...................................

1.2.1. First Wave of Regional Economic Cooperation in ECOWAS:

1970-1990s....................................................9

1.2.2. Second Wave of Regional Economic Cooperation in ECOWAS: 1990 to date..................................................13

1.3. Clarification of Terminologies.....................................16

1.4. Implementation Conundrum in ECOWAS............................20

1.5. Research Question and Sub-questions...............................23

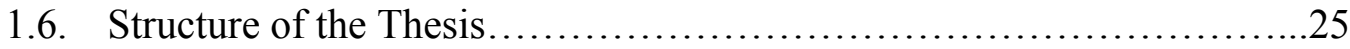

\section{CHAPTER 2: CONTEMPORARY UNDERSTANDINGS OF REGIONAL ECONOMIC COOPERATION IN AFRICA: ECOWAS.........................27}

2.1. Formalism and Flexibility in African Regional Trade Agreements.....27

2.2. Synthesis of the Emerging Implementation Conundrum................45

CHAPTER 3: TOWARD A SOCIO-LEGAL ANALYSIS OF ECOWAS...........50

3.1. Legal Formalism............................................. 51

3.2. Reconceptualizing Regionalism as a Social Phenomenon..................55

3.3. The New Regionalism Perspective to Contextualizing ECOWAS......62

3.3.1. Old Regionalism..........................................64

3.3.2. New Regionalism.........................................69

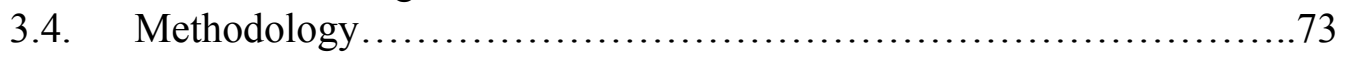

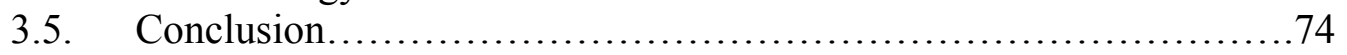




\section{CHAPTER 4: REVISITING THE ECONOMIC COMMUNITY OF WEST AFRICAN STATES ESTABLISHING TREATY ...............................76}

4.1. The ECOWAS Establishing Treaty................................77

4.2. Revisiting the Socio-Political and Economic Context of the Implementation of the ECOWAS Establishing Treaty..................82

4.3. The New International Economic Order...............................99

4.4. Situating the ECOWAS Trade Liberalization Scheme (ETLS) in the Socio-political Contexts of the 1980 to Mid-1990 West Africa..........103

4.5. Conclusion..........................................................111

\section{CHAPTER 5: REVISITING THE ECONOMIC COMMUNITY OF WEST AFRICAN STATES TREATY OF 1993......................................114}

5.1. Background: Socio-Political Context of the Revision of the ECOWAS Treaty...........................................................115

5.2. The ECOWAS Declaration of Political Principles......................120

5.3. The Revised ECOWAS Treaty........................................ 123

5.4. The ECOWAS Parliament...........................................129

5.5. Retelling the Socio-Political Context of the Implementation of the Revised ECOWAS Treaty................................................136

5.5.1. Tension between Regional Supranational Pull and National Sovereignty..........................................137

5.5.2. The Drowning Effect of Overlapping Membership and Conflicting Social Relations...........................................142

5.5.3. The Influence of Social Conflicts on the Implementation of the Revised ECOWAS Treaty ...................................145

5.5.4. The International Dimension of Power Relations: Renegotiation of the Economic Partnership Agreement...........................149

5.5.5. Power Relations: The Regional Context......................155

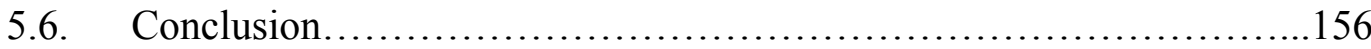

\section{CHAPTER 6: REVISITING THE EXPANSION OF THE ECOWAS COMMUNITY COURT OF JUSTICE TO HUMAN RIGHTS......................159}

6.1. The ECOWAS Community Court....................................160

6.2. The Socio-Political Context for the Expansion of the Community Court.........................................................170

6.3. Hybridity: Developmental Regionalism and Neoliberal Regionalism in the Community Court. 
6.4. Navigating the Implementation Conundrum in the Community Court........................................................178

6.4.1. Human Rights: Abolition of Slavery..........................181

6.4.2 Right to Education............................................ 184

6.5. Conclusion.................................................. 188

CHAPTER 7: CONCLUSIONS: A NEW NARRATIVE OF REGIONAL ECONOMIC COOPERATION IN ECOWAS..................................191

7.1. Introduction................................................. 191

7.2. Toward a Reappraisal of the Legacy of the ECOWAS Establishing Treaty...........................................................191

7.3. Reconceptualizing Effectiveness and Compliance for the Study of ECOWAS Treaties...............................................195

7.4. Impact of Power Dynamics, Geo-political and Social Conflicts.......................................................197

7.5. Colonial Legacies and Continuing Influence of Imperial Powers and International Institutions.......................................199

Bibliography.

.200 


\section{Acknowledgements}

In writing this thesis, I have benefited immensely from the guidance, scholarship, experience, intellect, and direction of an excellent community of Professors. To Professors Rita Abrahamsen and Graham Mayeda, my thesis co-supervisors, thank you very much for your unwavering support, commitment, encouragement, patience, and constructive feedback that has culminated in this thesis. I also acknowledge the support of Professors Mark Toufayan and Suzanne Bouclin who were my co-supervisors earlier in the doctoral program. Thank you for helping me develop the foundation for the writing of this thesis.

My sincere gratitude also goes to the Social Sciences and Humanities Research Council of Canada, the Nicole Senecal Graduate Scholarship in International Law, the Faculty of Graduate and Postdoctoral Studies, the Faculty of Law of the University of Ottawa, the Graduate Studies in Law at the Faculty of Law, and the Human Rights Research and Education Center for their generous support without which the completion of this thesis would not have been possible.

This thesis, which is the culmination of my doctoral work, was facilitated by the untiring love, motivation, care, and sacrifice of my immediate and extended family. To my darling wife, Esther, I will forever remain indebted to you for your labor of love and providing a shoulder for me to lean on during many difficult moments. To our beautiful children, Pearl and Jasper, thank you for understanding that "daddy can't play right now" 
during my seemingly endless writing sessions. To my parents, Clement and Roseline Akinkugbe thank you very much for giving me the greatest legacy that you could have offered: education. I must also express sincere gratitude to my parents-in-law, Mr. \& Mrs. Odepe, and to my siblings, Yemi, Shade, and Babarinde. Words cannot express how thankful I am to you all. 


\section{Chapter 1}

\section{The Dilemma of Law, Politics, and the Social in ECOWAS}

This introductory chapter sets out the problem and research question of the thesis. It provides the background for the substantive chapters by explicating the implementation conundrum in ECOWAS and contends that the conundrum can be explained by situating ECOWAS as embedded in the political, social, and economic structures of not only the Member States but also international institutions and the ideologies they promote. By implementation conundrum I refer to the nonfulfillment of the substantive aims and objectives of ECOWAS as expressed in the treaties. The chapter also provides a preview of the ensuing chapters.

\section{Background to the Study}

Post-colonial African states have been active participants in the exponential rise of regional economic organizations. Regionalism is a cardinal component of the socioeconomic and political development strategy of African states. Although many of the early regional economic organizations among these countries went moribund almost with the same ease as they were established, their contemporary functioning has been much steadier and gradually evolving in comparison to the earlier organizations.

In the West African sub-region, where the majority of other regional economic organizations that were established in the late 1960s and 1970s collapsed, ECOWAS 
survived the tide. ${ }^{1}$ Initially established in 1975 against the background of colonialism, the organization was reconstituted in 1993, via a revised treaty, to enhance its relevance in a fast-changing global world. ${ }^{2}$ The reconstitution of ECOWAS was necessitated by evolving but heterogeneous political, social, and economic factors at the national, regional, and international levels and simultaneously by complex socio-economic relations and social conflicts within the Community. ${ }^{3}$ Unlike the state-centric, protectionist, and import substitution industrialization of the 1970s, the evolution of the cross-border economic relations in the decades leading to the revision of the ECOWAS Treaty was characterized by several important developments: the introduction of the new economic ideology of neoliberalism that has taken root in ECOWAS Member States' countries since the 1980s; an open regionalism that called for deeper integration into the global market; an expansion of the substantive areas regulated by the regional economic treaties based on a concerted promotion of good governance agenda by the Bretton Woods Institutions; the expansion of the actors within the Community to non-state actors; and the strengthening of the institutions of regional economic governance primarily through the establishment of new institutions, particularly the judicial arm.

\footnotetext{
${ }^{1}$ On the notoriety of the proliferation of trade agreements in Africa during the early 1960 s to 1980 s, see Adebayo Adedeji, "History and Prospects for Regional Integration in Africa," speech delivered at the Third Meeting of the African Development Forum, Addis Ababa, 5 March 2002, available at http://dspace.cigilibrary.org/jspui/bitstream/123456789/9695/1/History\%20and\%20Prospects\%20for\%20R egional\%20Integration\%20in\%20Africa.pdf?1 (last visited 27 September 2013).

${ }^{2}$ In West Africa, two major regional economic groupings-ECOWAS and Union Economique et Monetaire Ouest Africaine (UEMOA) - endured the complex trajectory that many similar organizations could not endure. They respectively represent the anglophone and francophone countries within the West African sub-region, with some states having overlapping membership.

${ }^{3}$ See S. K. B. Asante, "The Strategy of Regional Integration in Africa," United Nations Economic Commission for Africa, text of two lectures delivered at a Public Forum organized by the Foreign Affairs Committee of Ghana Parliament in collaboration with Friedrich Ebert Stiftung, Ghana, Ministry of Foreign Affairs and the Legon Centre for International Affairs, University of Ghana, Legon, Accra, Ghana, 25 and 26 September 1996, 3, available online http://repository.uneca.org/bitstream/handle/10855/4409/Bib31592.pdf? sequence=1; also see Ablam Benjamin Akoutou, Rike Sohn, Matthias Vogl, Daniel Yeboah, eds., Understanding Regional Integration in West Africa-A Multi-Thematic and Comparative Analysis, West African Institute-Center for European Integration Studies Paper No. 17 (2014): 12.
} 
The dominant assessments of the implementation of ECOWAS have been critical of the organization. Mainstream analyses of the barriers to economic integration within ECOWAS focus on the institutional, legal, and infrastructural challenges that are generally conceptualized as the barriers to the implementation of the treaties. ${ }^{4}$ While the enumerations of these impediments are true, several other socio-political factors contribute to the implementation conundrum in ECOWAS. Regional economic cooperation schemes in Africa generally, and ECOWAS in particular, have been marred by political turbulence, economic instability, social conflicts, and ideological disagreements within and between states. The divergence in the socio-political relations of the Community members is traceable in part to the divisions between anglophone, francophone, and lusophone members of ECOWAS; to colonial legacies and the protracted post-colonial relationship between francophone ECOWAS members and France on the one hand and their anglophone counterpart, led by Nigeria, on the other hand; and, finally, to political fragmentation as members oscillate between military and "democratic" system of governance.

\footnotetext{
${ }^{4}$ See Iwa Salami, "Legal and Institutional Challenges of Economic Integration in Africa" (2011) 17:5 European Law Journal, 667; Anuke Ovrawah, "Harmonisation of Laws within the Economic Community of West African States (ECOWAS)" (1994) 6 Afr. J. Int'l \& Comp. L., 76; Bankole Thompson, "Legal Problems of Economic Integration in West African Sub-region" (1990) 2 Afr. J. Int'l \& Comp. L., 85; Bankole Thompson and Richard S. Mukisa, "Legal Integration as a Key Component of African Economic Integration: A Study of Potential Legal Obstacles to the Implementation of the Abuja Treaty" (1994) 20 Commonwealth L.Bull., 1446 at 1454; Yinka Omorogbe, "The Legal Framework for Economic Integration in the ECOWAS Region: An Analysis of the Trade Liberalisation Scheme" (1993) 5 Afr. J. Int'l \& Comp. L., 355 at 364-65.
} 
Given the inability of ECOWAS to achieve its substantive objective of trade liberalization and economic integration, critics contend that ECOWAS has "failed." The dominant failure analysis reflects "a teleological prejudice informed by the assumption that progress in regional organization is defined in terms of EU-style institutionalization." "These critical assessments have proceeded principally on the basis of economic integration theories that were developed in the context of developed societies. In this regard, the European Union (EU) has been promoted as the Holy Grail of regional economic organization to which most of its African counterparts should aspire. Such recommendations and approaches, however, ignore the fact that the socioeconomic and political structures around which the theories were developed in the EU differ significantly from the circumstances on the African continent. ${ }^{7}$

Fredrik Söderbaum describes two dominant overlapping schools of thought that are Eurocentric and have influenced thinking about regionalism in Africa. ${ }^{8}$ The "orthodox Eurocentric Perspective" is primarily associated with institutionalism and liberal schools

\footnotetext{
${ }^{5}$ Kofi Oteng Kufuor, "Public Choice Theory and the Failure of the ECOWAS Trade Liberalization Scheme" (2000) 23:4 World Competition, 137-154; Rasul Shams, "Regional Integration in Developing Countries: Some Lessons Based on Case Studies," Hamburgisches Welt-Wirtschafts-Archiv Discussion Paper 251, Hamburg Institute of International Economics, 1-35.

${ }^{6}$ Shaun Breslin, Richard Higgott, and Ben Rosamond, "Regions in Comparative Perspective," in New Regionalisms in the Global Political Economy, ed. S. Breslin, C. Hughes, N. Philips, and B. Rosamond (London: Routledge, 2002), 11.

${ }^{7}$ William Ropke, International Order and Economic Integration, (Holland: D. Reidel Publishing Company; 1959).

${ }^{8}$ Fredrik Söderbaum, "What's Wrong with Regional Integration? The Problem of Eurocentrism," Robert Schuman Centre for Advanced Studies (RSCAS), Global Governance Programme-63, 2013/64, European University Institute, 1-15, http://gup.ub.gu.se/records/fulltext/191428/191428.pdf. (The study describes "how Eurocentrism (in various guises) negatively affects both theoretical development, empirical analysis and policy debates as well as offer some ways to rethink regionalism and regional integration.") For an insightful critical take on Eurocentrism in International Relations, see M. Millerman, "Theory Talk \#71: John M. Hobson on Eurocentrism, Historical Sociology and the Curious Case of Postcolonialism," Theory Talks, 2015, http://www.theory-talks.org/2015/09/theory-talk-71.html (Last visited 23 August 2017); James Thuo Gathii, "International Law and Eurocentricity" (1998) 9 European Journal of International Law 184211.
} 
of thought that "concentrate on formal interstate frameworks and/or official trade and investment flows, commonly with reference to the [European Community/European Union] as a comparative marker or model." 9 The "pan-African school of thought," by comparison, "is a set of synoptic overviews of African regional organizations and political-economic relationships which are then coupled with demands for the strengthening of pan-African regional organizations." ${ }^{10}$ Apart from being state-centric, Söderbaum argues that the pan-African school of thought "often takes the EC/EU experience as inspiration, and as a justification for the development of pan-African regionalism." 11 The recent events in the EU demonstrate the frailties of an organization that has been touted for several years as the model organization while also underscoring the need for caution in wholesale uncritical transplantation of this model. ${ }^{12}$ In this regard, Söderbaum admonishes that Eurocentrism (in its various forms) is detrimental to theoretical development, empirical analysis, and policy debates. ${ }^{13}$

Therefore, to apply these theories to the study of African regional economic communities such as ECOWAS without rigorously accounting for the different complex socio-political relations and contexts that inform ECOWAS' establishment and implementation would hardly capture the reality of why Member States cooperate. The outcome of such analyses is likely to be reductionist, abstract, or too narrow if the objective is simply about classic trade liberalization and economic union. The point here is neither to argue for African

\footnotetext{
${ }^{9}$ Söderbaum, "What's Wrong with Regional Integration?," 1, 8.

${ }^{10}$ Ibid.

${ }^{11}$ Ibid.

${ }^{12}$ See Christopher Lord, "Fragmentation, Segmentation and Centre Formation: Some Thoughts on the UK and European Integration from 1950 to Brexit," ARENA Working Paper 3/2017, ARENA Centre for European Studies, 1-20.

${ }^{13}$ Söderbaum, "What's Wrong with Regional Integration?," 1.
} 
exceptionalism nor to suggest that comparative regional studies are irrelevant or superfluous. Instead, the thesis acknowledges that valuable lessons can be learned from the EU; analyses that focus on the text of the treaties alone do not capture the broader political, historical, economic, social, and cultural complexity of African states. If, as is the case, Member States have reinforced their belief in regional cooperation despite the failure claims, it is imperative that scholars seek new approaches that account for and illuminate our understanding of the rationale for the persistence - even if they divergefrom the mainstream understanding of the operation of these schemes. This thesis takes up this challenge.

To account for the implementation conundrum in ECOWAS, the thesis argues for a contextualized rethinking of the theory and practice of regionalism in West Africa. Such an approach does not preclude drawing on experiences from other regions, but it is retooled and broadened to apprehend the socio-political structures within which the regional organizations are embedded, as opposed to seeking to fit ECOWAS in a preexisting straight jacket of ideas. The emphasis on the interaction of the triad of political, economic, and social contexts of West Africa differs from the idea of "inverted Eurocentrism' (whereby theory and practice, by definition, must be 'different' compared to Europe) or a different form of parochialism (where context is all that matters)." 14 Rather, I draw attention to the fact that a wholesale adoption of the EU as the "marker, model and paradigm from which to theorize, compare and design [regional] institutions

\footnotetext{
${ }^{14}$ Ibid.
} 
as well as policy in the rest of the world" traffics a false universalism about the social and power relations that are embedded in such interactions. ${ }^{15}$

In the next section, I provide an analysis of the two overlapping eras of ECOWAS. I organize the analysis in two broad waves that foreshadow the different economic, political, and social factors to understanding each phase and the ECOWAS treaties in the subsequent chapters. The periodization is not intended to be static or monolithic, but instead fluid, overlapping, and reflecting the complex simultaneous existence and interaction of different ideas and events within which ECOWAS had emerged and evolved, and is now being implemented. This introductory analysis will be expanded and deepened in chapters 4,5 , and 6 .

\subsection{Waves of Regionalism in West Africa}

The periodizations of regionalism in Africa are not uniform. S. K.B. Asante classifies the development of regionalism in Africa into two broad categories with totally different content and periods: the "first" and "second" waves of regionalism. Asante's first wave of regionalism includes a mix of early international and regional organizations from Europe, Asia, Latin America, and Africa, such as the European Coal and Steel Community of 1951, European Economic Community of 1957, Latin American Free Trade Association of 1960, Central American Common Market of 1961, the Central African Economic and Customs Union of 1964, and the Caribbean Free Trade

\footnotetext{
${ }^{15}$ Ibid. On the interaction of importance of compatibility between norms that underlie institutions and the social, cultural, and political context of a given society, see Graham Mayeda, "Appreciate the Difference: The Role of Different Domestic Norms in Law and Development Reform-Lessons from China and Japan" (2006) 51:3 McGill Law Journal, 547-598, and 559-561.
} 
Association of 1968. His second wave of regionalism started in the mid-1980s, when a "new-found or rediscovered enthusiasm for regional economic integration had been evident in Europe, Africa, and North and South America." ${ }^{16}$ Asante argues that the second wave was motivated not only by the success of the EU and North American Free Trade Agreement but also the slow pace of the General Agreement on Trade and Tariff (GATT) meant that the decline in the confidence nations had in it led to the rise of regional integration. Walter Kennes similarly identifies two periods: (i) 1960-1980; and (ii) 1991 up to the signing of the African Economic Community agreement. This in turn is criticized by Emmanuel Obuah who argues that a "better periodization of the development of regionalism in Africa which takes account of the impetus from the international as well as the local environments will suffice to divide the development of regionalism into the $1960 \mathrm{~s}-70$ s, and 1980s to present." ${ }^{17}$

For the purpose of studying ECOWAS, this thesis divides the trajectory into two broad categories - in 1970 to 1990 s; and 1990 to date. As opposed to being static and linear, this classification contrasts existing periodizations because it recognizes that the periods are at the same time distinct and heterogeneous, overlapping and fluid, and take into account the complex interaction of various socio-political factors at the regional, national and international levels with significant impact on the implementation of the ECOWAS Treaties.

\footnotetext{
${ }^{16}$ S. K. B. Asante, Regionalism and Africa's Development, Expectations, Reality and Challenges (Great Britain: McMillan Press Limited, 1997), 2-8 (hereinafter referred to as Regionalism and Africa's Development).

${ }^{17}$ Emmanuel Obuah, Review of Regionalization in Africa: Integration and disintegration edited by Daniel Bach 1999, in (2001) 39:1 Journal of Modern African Studies, 168-171 at 170.
} 


\subsubsection{First Wave of Regional Economic Cooperation in ECOWAS: 1970-1990s}

The establishment of ECOWAS and its subsequent implementation occurred in a contested regional and international environment with varying, yet overlapping, economic, political, and social conflicts. The majority of ECOWAS Member States gained political independence in the 1970s. For these new West African states, the struggle against colonialism was not just to gain their sovereignty and free themselves from external economic and political domination, it was also about keeping their sovereignty as states. Viewed against the colonial background and the pan-African agitations, the new African states have consistently resisted economic or political processes that could fetter their national sovereignty. ${ }^{18}$ Their participation in regional cooperation should, therefore, be studied by taking into account that at the national level, regionalism provided an avenue for the consolidation of political sovereignties. It is important to also note that although colonialism had ended, its impact had not ceased and was still prevalent in the 1970s. Hence, from the perspective of ECOWAS Member States, regional integration as opposed to regional cooperation in the traditional sense of supranational organization is perceived as a process that potentially limits their hardgained sovereignty and threatens their decision-making capabilities.

Economically, the decade from 1970 to 1980 was dominated by theories of the developmental state. ${ }^{19}$ Privileging the state as the sole actor, its economic prescriptions

\footnotetext{
${ }^{18}$ See Emmanuel Fanta, "Understanding Regional Integration Policies in Africa," in Comparative Regionalisms for Development in the 21st Century: Insights from the Global South, ed. Emmanuel Fanta, Timothy M. Shaw, and Vanessa T. Tang (Farnham: Ashgate, 2013), 41-56, and 46.

${ }^{19}$ See Chalmers Johnson, "The Developmental State: Odyssey of a Concept" in The Developmental State, ed. Woo-Cumings (Cornell, CA: Cornell University Press, 1999), 32-60; Ziya Öniş, "The Logic of the Developmental State" (1991) 24:1 Comparative Politics, 109-126; Omano Edigheji, "A Democratic
} 
included import substitution industrialization (the prevalent national economic policy in many Member States), protectionism, and nationalization of foreign-owned companies in the case of some countries such as Nigeria. With the newly found political sovereignty, many African countries were eager to reverse the economic impact of colonization. Hence, in addition to the national measures, at the international level African states participated in the move to restructure the oppressive international economic order in the 1970s. However, the effort by Third World countries to restructure the international economic order of the 1970s was not successful, at least not in the terms anticipated by the Third World countries. ${ }^{20}$

Perhaps the narrative of ECOWAS would not merit revisiting, as undertaken by this thesis, if there were no twists and turns to complicate the narrative. For many ECOWAS Member States who are raw material-producing countries, the failure of the New International Economic Order (NIEO) dealt a major blow to their aspirations for economic equality and participation in decision-making processes that affect them and are binding on them. With the exception of Nigeria, many of these states remained externally oriented, depending on development assistance and primary goods export in their economic relations. While the economic fortune of anglophone ECOWAS States was less intertwined with Britain than the francophone states with France, ECOWAS Member States continued to trade primarily with their former colonial masters rather than with each other.

\footnotetext{
Developmental State in Africa? A Concept Paper", Research Report, Center for Policy Studies, May 2005, Johannesburg, 1-18.

${ }^{20}$ For recent accounts that revisit the new international economic order with nuance and caution against outright failure of the project, see Nils Gilman, "The New International Economic Order: A Reintroduction,” Special Issue ed., (2015) 6:1 Humanity, http://humanityjournal.org/issue-6-1/.
} 
One of the critical developments that emerged from the collapse of the new international economic order was the ascension of neoliberalism in the 1980s. The trapping effects of the original neoliberal ideology and its chastened form-post-Washington Consensuscontinue today, though in a significantly diminished form. From 1980 to 1993, neoliberalism and its emphasis on a limited role for the state co-existed with ECOWAS Establishing Treaty that was underpinned by a developmental state ideology with the state as the sole actor. At the continental level, African states responded to the failure of the new international economic order with the conclusion of the Lagos Plan of Action in 1980. ${ }^{21}$ The Plan called for collective self-reliance by African countries in response to the preceding international economic order that had a negative impact on their economies. These events mark a sharp turn from the decade of 1970-1980. The intricate implication of the overlap between developmental state and neoliberalism for the implementation of ECOWAS at the turn of the 1980s and beyond has yet to be rigorously accounted for in the literature on regionalism in West Africa. This thesis explicates this complexity and the implication of the overlap for the implementation of ECOWAS Establishing Treaty.

The scholarship on the implementation of the ECOWAS Establishing Treaty is replete with negative normative evaluation of the organization. It accounts for the poor performance and low effectiveness of ECOWAS mostly from structural and institutional

\footnotetext{
${ }^{21}$ United Nations Economic Commission for Africa, "Appraisal and Review of the Impact of the Lagos Plan of Action on the Development and Expansion of Intra-African Trade," UNECA Conference of African Ministers of Trade Meeting, 11th session, 15-19 April -1990, Addis Ababa, Ethiopia, http://hdl.handle.net/10855/14129.
} 
perspectives, while also enumerating the legal challenges that confront ECOWAS. ${ }^{22}$ While some directly compare ECOWAS to the EU, others attribute its weak performance to a series of factors that include but are not limited to: the lack of political will to establish supranational institutions and to follow up with the implementation of agreed upon treaties and mandates; an earlier pursuit of import substitution industrialization policy and the concomitant establishment of inefficient industries that were unable to compete with those in developed countries; weaknesses of regional institutional structures or lack thereof; political instability; and lack of rule of law and good governance. ${ }^{23}$ Another perspective is the idea that state-led regionalism, which characterized early post-colonial Africa, was weak and destined to fail because the organizations existed largely to perpetuate the interests of the powerful Member States in the community. Even if regional cooperation was at an all-time high during this era, it was geared towards the consolidation of national economic and political sovereignty as opposed to the economic integration of the region as understood by mainstream scholarship. Yet, significant aspects of the critique of ECOWAS pay little or no attention to these complexities. It is as if the effects of colonialism abated once the states achieved political independence.

\footnotetext{
22 "Africa's integration efforts have not achieved much harmonization and coordination of standards, legislation, rules and regulations, or of institutions regulating economic interaction." Percy S. Mistry, “Africa's Record of Regional Co-operation and Integration" (2000) 99:397 African Affairs, 553-573, 557.

${ }^{23}$ See James Thuo Gathii, "A Critical Appraisal of the NEPAD Agenda in Light of Africa's Place in the World Trade Regime in an Era of Market Centered Development" (2003) 13 Transnational Law \& Contemporary Problems, 179; James Thuo Gathii, "Retelling Good Governance Narratives on Africa's Economic and Political Predicaments: Continuities and Discontinuities in Legal Outcomes Between Markets and States" (2000) 45 Villanova Law Review, 971.
} 


\subsubsection{Second Wave of Regional Economic Cooperation in ECOWAS: 1990 to date}

Although this thesis pitches the periodization of the second wave in 1990, neoliberalism, which was the dominant economic order, predates this period. This overlap reinforces the nuance and fluidity that the periodization adopted in this thesis illuminates. In particular, during the early 1980s the World Bank and the International Monetary Fund promoted structural adjustment programs and loan conditionalities. These neoliberal proposals were imposed on the socio-economic and political fabric of developing countries, including ECOWAS Member States. However, despite the fact that its imposition in the national context dates back to early 1980s, the impact of neoliberal ideologies on the design of regionalism did not occur until the 1990s. Yet, as it relates to regionalism, because of the early impact of neoliberalism in national economies during the 1980s, it impacts the role of the Member States in ECOWAS, who are the primary and sole actors, and sharply conflicts with neoliberal ideologies.

Economically, by the 1990s most ECOWAS Member States continued to struggle despite the adoption of the neoliberal policies of deregulation, structural adjustment programs, privatization, and non-distortionary actions by the state prescribed by the World Bank and the International Monetary Fund. In fact, whereas states like Nigeria were financially buoyant as a result of oil boom in the late 1970s, by the 1990s Nigeria's economy struggled to match its previous heights. With globalization in full force, a key dominant feature of the new era was the resounding call for open markets and deeper integration of developing countries into the international economy. The conclusion of the Uruguay round of negotiations and establishment of the World Trade Organization in 1995 
provided impetus for the promotion of regional trade agreements as instruments that would enhance open markets. However, international calls for open markets did not take into account the unequal economic position of many developing countries, the implication of open markets for the smaller industries in developing countries, as well as the impact on economic cooperation in the regions. Since regionalism was not a traditional avenue by which these countries traded among each other, the promotion of regional trade agreements by the World Trade Organization would only reinforce the topdown approach of the 1970s and protect the place of developed countries in the global economy by undermining the national sovereignty of the developing countries. ${ }^{24}$ In addition to the changes in the international economic order that necessitated the revision of the founding treaties of many African regional economic communities in the 1990s, the creation of the World Trade Organization and the globalization of new forms of regional trade agreements also heralded the promotion of supranational authority as an important feature of the new organizations.

Politically, the situation for many ECOWAS Member States evolved as the 1990s drew to a close. Whereas many countries started the 1990s under military administration, by the new millennium many had held multiparty elections or were in transition to civilian administration. ${ }^{25}$ The rise of democracy, constitutionalism, and multiparty elections across African countries cannot be separated from the wider changes in the international

${ }^{24}$ See Robert E. Hudec, Developing Countries in the GATT/WTO Legal System (London: Gower Publishing, 1987); Shiela Page, "Developing Countries: Victims or Participants, their Changing Role in International Negotiations," Overseas Development Institute, Globalization and Poverty Programme, 2003; Joshua Meltzer, "State Sovereignty and the Legitimacy of the WTO" (2005) 26:4 University of Pennsylvania Journal of International Economic Law, 693-733.

${ }^{25}$ See Pacifique Manirakiza, "Insecurity Implications of Unconstitutional Changes of Government in Africa: From Military to Constitutional Coups" (2016) 17:2 Journal of Military and Strategic Studies, 86106. 
political climate, including the promotion of the good governance proposals - rule of law, popular participation, transparency, human rights - by the Bretton Woods Institutions, the political conditionalities to accessing international assistance, the fall of the Berlin Wall, and Communism. ${ }^{26}$ On the face of it, it would appear that the change to democratic governance should bode well for the implementation of the ECOWAS Treaty, especially taking into consideration the structural and institutional changes in ECOWAS. ${ }^{27}$ However, social conflict and civil war in some of the Member States would add to the complexity of the implementation of ECOWAS in the new era. These developments foreground the complexity of globalization and the amplifying of unequal economic and political power structure among Member States.

To summarize, in periodizing the two ECOWAS eras, it is crucial to incorporate sufficient nuance to allow for the significant overlap of the underpinning theories and the various socio-political factors at the international, regional, and national levels. While there are significant differences between the two periods, there are no watertight, clearcut breaks. Instead the two periods bleed into one another and changes occur gradually over time. This thesis unpacks these complex socio-political relations with a view to understanding their influence on the implementation of ECOWAS. In the next section, I clarify the use of some terms in the thesis.

\footnotetext{
${ }^{26}$ Christopher Clapham, Africa and the International System. The Politics of State Survival (Cambridge: Cambridge University Press, 1996); Nic Cheeseman, Democracy in Africa: Success, Failures and the Struggle for Political Reform (Cambridge: Cambridge University Press, 2015); Jean-Francois Bayart, The State in Africa: Politics of the Belly, 2nd ed. (Cambridge: Cambridge University Press, 2009).

${ }^{27}$ See Dirk Berg-Schlosser, "Indicators of Democracy and Good Governance as Measures of the Quality of Democracy in Africa: A Critical Appraisal” (2004) 39:3 Acta Politica, 248-78.
} 


\subsection{Clarification of Terminologies}

In this section, I discuss salient differences in the use of the terms regional economic cooperation and regional economic integration. The clarification is important as the use of either term has implications for the conceptualization of the regional organizations. ${ }^{28}$ According to Ernst Haas, the mainstream study of regional economic integration is concerned "with explaining how and why states cease to be wholly sovereign, how and why they voluntarily mingle, merge, and mix with their neighbours so as to lose the factual attributes of sovereignty while acquiring new techniques for resolving conflict between themselves." ${ }^{29}$ It is a process "whereby political actors in several distinct national settings are persuaded to shift their loyalties, expectations, and political activities towards a new larger centre, whose institutions possess or demand jurisdiction over the pre-existing state. ${ }^{\prime 30}$ Speaking of the lack of commitment of African leaders to regional economic integration, Percy Mistry notes that

Africa's commitment to [regional] integration appears to have been visceral rather than rational, more rhetorical than real. African integration ideals have been based on lofty transcontinental ambitions, evocative political slogans, a plethora of treaties and regional institutions, high-minded principles, and protectionist proclivities. African notions of economic integration have not been grounded in the day-to-day practical realities of the continent's economic or political life. Nor has integration been seen (until recently) as a step to be taken for Africa to cope in a rapidly globalizing world that demands everincreasing competitiveness. ${ }^{31}$

\footnotetext{
${ }^{28}$ See Daniel C. Bach, "Regionalism vs. Regional Integration: The Emergence of a New Paradigm in Africa," in Regionalism Across the North/South Divide: State Strategies and Globalization, ed. Jean Grugel and Wil Hout (London: Routledge, 1999), 136-48.

${ }^{29}$ Ernst B. Haas, "The Study of Regional Integration: Reflections on the Joy and Anguish of Pretheorizing" (1970) 24:4 International Organization, 607-646, 607-08, 610; Haas, "International Integration and the Universal Process" (1961) 15:3 International Organization, 366-92. An earlier definition by Haas defines regional integration as "the process whereby political actors in several distinct national settings are persuaded to shift their loyalties, expectations and political activities toward a new center, whose institutions possess or demand jurisdictions over the pre-existing national states." See, Ernst B. Haas, The Uniting of Europe: Political, Social and Economic Forces 1950-57 (Stanford: Stanford University Press, 1958), 16.

${ }^{30}$ Haas, "International Integration: The European and the Universal Process", 366-67.

${ }^{31}$ Mistry, "Africa's Record of Regional Co-operation and Integration", 557. Also see Yongzheng Yang and Sanjeev Gupta, "Regional Trade Agreements in Africa: Past Performance and the Way Forward," IMF Working Paper WP/05/36, February 2005, 1-36; United Nations Conference on Trade and Development,
} 
Regional economic integration is also the outcome of instrumental state policies aimed at strengthening the sovereignty of Member States when negotiating in greater numbers in favour of broader and collective interests of the participating states within the region. Whereas regional economic integration "by definition implies loss of sovereignty, voluntary or through pressure, [regional economic cooperation] does not. This does not make [regional economic cooperation] less important, as some suggest, but it does call for different concepts and approaches to the study of the phenomena." ${ }^{„ 32}$ The EU provides the prime example of regional economic integration. S. K. B Asante, a renowned scholar of regionalism in Africa, cautions that the peculiar nature of West African economies and the evolution of regionalism in the region "make it unrealistic to apply the term "integration" in the same sense as used in the developed countries." ${ }^{\text {"33 }}$ Asante argues that in thinking about regionalism in West Africa, the economic, social, and political realities of the region must be borne in mind in comparison to other sub-regions as West Africa exhibits different features that must be taken into account. ${ }^{34}$ Regional economic integration connotes deeper processes, harmonized legal relationships, ${ }^{35}$ and policy coordination among the Member States, which could eventually lead to the formation of a

\footnotetext{
"Economic Development in Africa Report 2009: Strengthening Regional Economic Integration for Africa's Development," United Nations, New York, and Geneva, 2009, http://unctad.org/en/Docs/aldcafrica2009 en.pdf.

32 Amitav Acharya, Rethinking Power, Institutions and Ideas in World Politics: Whose IR? (2013: Routledge)

${ }^{33}$ See S. K. B. Asante, "Report on an Advisory Mission on Review of the ECOWAS Treaty-Regional Economic Cooperation and Integration Options," ECO/RA/91/1, 3.

${ }^{34}$ Specifically, Asante identified eight factors: heavy population of the region, largest number of countries, contains the largest number of intergovernmental organizations, region embraces two major ecological zones, contains a relatively large coastline, artificiality of the frontiers, or national boundaries. Ibid., 3-5.

${ }^{35}$ On the perils of universal harmonization as an ineffective tool for dealing with development issues in the context of SPS and TBT Agreements with lessons for international trade among developing countries broadly, see Graham Mayeda, "Developing Disharmony? The SPS and TBT Agreements and the Impact of Harmonization on Developing Countries" (2004) 7:4 Journal of International Economic Law, 737-64.
} 
common market, a common currency, free trade area, or even economic union in the long term.

The thesis argues that regionalism in Africa has never been about regional economic integration. The Member States of the organizations neither have the comparative advantage to trade as envisaged by neoclassical theories, nor do they empower the organizations to truly act as a supranational body, or in the limited cases where they do, their practice diverges from the commitment in the treaties. Another key inference to note is that to conceptualize the organizations as existing for the purpose of integration of the economies of the Member States - as traditionally understood - sustains the narrative of failure. For the purpose of this thesis, regional economic cooperation is adopted as the ideal concept that encompasses the series of regional activities among ECOWAS Member States.

Regional economic cooperation connotes the common desire shared by Member States of a regional organization with respect to a particular issue(s) and may specifically involve the "execution of joint projects, technical sector cooperation, common running of services and policy harmonization, and joint development of natural resources. ${ }^{36}$ Unlike regional economic integration, it implies a flexible, loose, and weak regional centre with no power to make binding decisions on the Member States. The Member States cooperate around specific issues or projects as opposed to a committed desire to integrate their

\footnotetext{
${ }^{36}$ M. Lee, "Regionalism in Africa: A Part of Problem or a Part of Solution" (2009) Polis/R.C.S.P./C.P.S.R. vol. 9, Numéro Spécial, 3.
} 
policies in a strong and legally binding regional centre. ${ }^{37}$ States therefore substantially retain their political and economic sovereignty. Tanja A. Börzel puts the difference sharply:

Regionalism can be placed on a continuum with regional (intergovernmental) cooperation and regional (supranational) integration as two opposite ends. Regional cooperation entails the joint exercise of state-based political authority in intergovernmental institutions to solve collective action problems related to economic, political or security issues. Regional integration, by contrast, involves the setting-up of supranational institutions to which political authority is delegated to make collectively binding decisions. ${ }^{38}$

As it relates to this thesis, the distinction is important not only because it mirrors the two opposite ends of the substantive aspirations ECOWAS Member States enshrined in the treaties, but also because regional economic cooperation allows the flexibility to incorporate the analysis of the socio-political contexts, how they are the embedded in the social relations of the Member States and the social structure in the West African subregion and their influences on the implementation of the treaties.

\subsection{Implementation Conundrum in ECOWAS}

In this section, I introduce the background to what this thesis calls the implementation conundrum in ECOWAS. Critics ${ }^{39}$ of ECOWAS contend that the claim to regional

\footnotetext{
${ }^{37}$ According to Hettne and Söderbaum the historical context of regional cooperation was the "bipolar world order, which imposed a cold war logic on regionalization (hegemonic regionalism), not only in Europe but also in other areas where regional integration experiments were initiated." See Björn Hettne and Fredrik Söderbaum, "Regional Cooperation: A Tool for Addressing Regional and Global Challenges" in International Task Force on Global Public Goods, Achieving Global Public Goods (Stockholm: Foreign Ministry, 2006), 179-244, 182-83.

${ }^{38}$ Tanja A. Börzel, "Comparative Regionalism: A New Research Agenda," KFG Working Paper Series, no. 28, August 2011, ed. Kolleg-Forschergruppe (KFG) "The Transformative Power of Europe," Freie Universität Berlin, 9-10.

${ }^{39}$ Mistry, "Africa's Record of Regional Co-operation and Integration"; Kofi Oteng Kufuor, "Public Choice Theory and the Failure of the ECOWAS Trade Liberalisation Scheme" (2000) 23:4 World Competition, 137-154; Kofi Oteng Kufuor, The Institutional Transformation of the Economic Community of West African States (England: Ashgate, 2006); Mamit Deme, "The Impact of ECOWAS on Intraregional Trade
} 
economic cooperation does not seem to transcend beyond signing of treaties and protocols. Despite the criticisms, ECOWAS remains one of the most ambitious and dynamic regional economic communities in Africa. ${ }^{40}$ Like many regional economic cooperation initiatives in Africa, it is plagued by significant challenges. Some of the critics have focused on the relationship between the ECOWAS Community's legal order and the national legal systems of its Member States as an area of contestation that affects the performance of the organization. ${ }^{41}$ The idea is that explicating the relationship between the regional and national legal orders has implications for the enforcement or non-enforcement of the ECOWAS Community laws in the Member States. A legal order established and respected by Member States has been critical to the success and effectiveness of organizations such as the EU, which has been recommended as the ideal model across developing countries. The universalism that underpins these prescriptions has come under scrutiny by many African and Africanist scholars of regionalism. The rationale for regional cooperation in Africa was not based solely on the functionalist ideas about regionalism or the neoclassical economics and customs union theory that placed emphasis on trade diversity and competitive advantage. Regional economic cooperation amongst these states was beyond trade.

Flows: An Empirical Investigation" (1995) 23:3 The Review of Black Political Economy, 113-29; Yang and Gupta, "Regional Trade Agreements in Africa: Past Performance and the Way Forward."

${ }^{40}$ See S. K. B. Asante, "Development and Regional Integration since 1980," in Economic Crisis in Africa: African Perspectives on Development Problems and Potentials, ed. A. Adedeji and T. M. Shaw (Boulder, CO: Lynne Rienner Publishers, 1985), 83. Aghaji observes that the "the [establishing] treaty of ECOWAS was motivated by the recognition that external dependency is not an answer to development and the overriding need among member states to accelerate, foster and encourage the economic and social development of their states." J. C. Aghaji, "ECOWAS: Is it a Countervailing Power for Economic Independence?" (1979) 14:1-2 Journal of Asian and African Studies, 110; also see Toyin Falola and Julius O. Ihonvbere, eds., Nigeria and the International Capitalist System, (Boulder, CO: Lynne Rienner, 1988).

${ }^{41}$ Richard Frimpong Oppong, "The African Union, The African Economic Community and Africa's Regional Economic Communities: Untangling a Complex Web" (2010) 18 Afr. J. Int'1 \& Comp. L., 92, 103. 
According to Fanta, "the overbearing European experiment in regional integration has cast a long shadow over the study of other forms of regionalisms as those taking place in Africa. ${ }^{42}$ As an alternative to the narrow focus on the European Union, scholars have called for a broader and more comparative approach to studying regional integration, such as the Association of Southeast Asian Nations (ASEAN) and the Latin American examples, with a view to reviewing the different experiments in integration so as to learn and apply them to the African regional economic communities. ${ }^{43}$ While comparative studies may be useful in drawing lessons for improving the performance of regional economic communities in Africa generally, a preliminary or simultaneous step is the production of studies that focus on and seek to understand the particular trajectory of each of the organizations.

By their nature, regional economic cooperation treaties contain provisions in advance of reality. These treaties take as given the existence of the right economic, political, and social conditions for their implementation and proceed to set targets not only for their complete or partial integration but also sometimes to establish new international or supranational institutions that purport to restrict the autonomy of national institutions. ${ }^{44}$ According to Yash Ghai,

\footnotetext{
${ }^{42}$ Ibid. Also see A. Acharya and A. I. Johnston, "Comparing Regional Institutions: An Introduction," in Crafting Cooperation: Regional International Institutions in Comparative Perspective, ed. A. Acharya and A. I. Johnston (Cambridge: Cambridge University Press, 2007), 1-31.

${ }^{43}$ Emmanuel Fanta, "Understanding Regional Integration Policies in Africa," in Comparative Regionalisms for Development in the 21st Century: Insights From the Global South, ed. Emmanuel Fanta, Timothy M. Shaw, and Vanessa T. (Farnham: Ashgate, 2013), 41-56; also see L. Fawcett, and H. Gandois, "Regionalism in Africa and the Middle East: Implications for EU Studies" (2010) 32:6 Journal of European Integration, 617-36.

${ }^{44}$ Yash Ghai describes ECOWAS Establishing Treaty as "an incredibly optimistic...and unrealistic document" because despite provisions guaranteeing free movement of labour and entrepreneurs, many states at the time were deporting nationals of neighbouring countries. See generally Yash P. Ghai,
} 
the "forward lookingness" of economic integration treaties can be an advantage. Provided that the negotiations for the treaty have been realistic, based on adequate preparations and a reasonable understanding of its implications, the "forward lookingness" can provide the treaty and its institutions with a certain built-in dynamism. ${ }^{45}$

Regional economic cooperation projects are, however, a social and political phenomenon that is embedded in the social structure of the Member States. They are as much a product of economic and political decisions as of the legal decisions.

To understand the multidimensional focus of ECOWAS Treaties, the legal, sociopolitical, as well as the historical context are inextricably linked to their implementation and should not be viewed in isolation. In relation to ECOWAS, there remains a significant blind spot in the analysis of how the implementation of the treaties has been and is being shaped by socio-political factors. This thesis challenges the mainstream analyses that undertake a primarily textual analysis of the ECOWAS Treaties without the context of their operation. The thesis deepens our understanding of the broad spectrum within which ECOWAS operates by foregrounding the political, economic, and social factors that influence the implementation of its policies. The need for such a broad approach derives from the fact that the objectives of regional economic communities in ECOWAS are multidimensional. Hence, while the importance of law to fostering economic cooperation is acknowledged, it only represents one of numerous components required for successful implementation. To place the multiple objectives in context and to illuminate the implementation conundrum, the historical, social, political, and economic

\footnotetext{
"Reflections on Law and Economic Integration in East Africa," Research Report No. 36, The Scandinavian Institute of African Studies, Uppsala, Sweden, 1976, 9-10.

${ }^{45}$ Ibid., 10. He contends further that the early success of the European Economic Community, and the status its Commission achieved, are attributable in large measure to the dynamism built into the treaty.
} 
factors at play within the region must be accounted for as well. In the next section, I discuss the principal research question and sub-questions undertaken by the thesis

\subsection{Research Question and Sub-questions}

The principal research question of this thesis is: How has the implementation of the ECOWAS Treaty of 1975 and the revised Treaty of 1993 been shaped and influenced by the changing historical, economic, and political conditions? Analytically, this question is posed as: To what extent does a socio-legal and contextual reading of ECOWAS modify the dominant interpretation of failure of the organization?

Recent years have seen a growing scholarly interest in the conditions of emergence of regional economic communities in Africa. While this body of influential scholarship enriches our understanding of regional economic communities, academic inquiry on ECOWAS has not delved sufficiently deeply into how the trajectory of the organization has been shaped and influenced by the changing historical, economic, and political conditions in the region and globally. While legal scholarship has recently begun paying attention to the legal aspects of regional economic cooperation in Africa, ${ }^{46}$ there are still gaps in the literature that illuminate the implementation conundrum in the specific regional economic communities.

\footnotetext{
${ }^{46}$ See Kufuor, The Institutional Transformation of the Economic Community of West African States. The author examined the institutional evolution of ECOWAS through the lens of the New Institutional Economic School of thought. While paying particular attention to the relationship between domestic, regional, and international legal arrangements, he questions the optimism of the Revised ECOWAS Treaty and the overt reliance on the precedent of the European Union. Also see Richard Frimpong Oppong, "Review of The Institutional Transformation of the Economic Community of West African States by Kofi Oteng Kufuor" (2008) 16 African Journal of International and Comparative Law 115-18; also see Eric M. Edi, Globalization and Politics in the Economic Community of West African States (Durham, NC: Carolina Academic Press, 2007).
} 
However, most of the legal scholarship that queries the ineffectiveness of ECOWAS has been underpinned by legal formalism. Unlike the majority of analyses that are underpinned by legal formalism, this thesis revisits the trajectory of ECOWAS since its creation by analyzing how the ECOWAS Treaties and their implementation are embedded in the broader socio-political structures and relations of its members. ${ }^{47}$ "Embeddedness," according to Granovetter is the idea that the "behaviour and institutions to be analyzed are so constrained by on-going social relations that to construe them as independent is a grievous misunderstanding. ${ }^{, 48}$ To conduct an analytical and empirical analysis of the implementation of the ECOWAS Treaty, I adopt a socio-legal approach that emphasizes the interconnectedness and mutually reinforcing nature of the legal, social, historical, economic, and political aspects of society. The thesis challenges the dominant narrative of failure that permeates most studies on ECOWAS, while simultaneously enriching the literature by broadening and deepening the analysis of the organization and the implementation or non-implementation of its stated objectives.

Adopting an interdisciplinary approach that combines socio-legal analysis with insights from International Relations scholarship on new regionalism in Africa, the thesis develops an original and distinct analysis of ECOWAS. Rather than taking a static and linear approach that belies the complex history of the regionalism in West Africa, this

\footnotetext{
${ }^{47}$ M. Granovetter, "Economic Action and Social Structure: The Problem of Embeddedness" (1985) 91:3 American Journal of Sociology, 481-510, 487; Eric M. Edi, "Economic Institutions as Social Constructions: A Framework for Analysis" (1992) 35:1 Acta Sociologica, 3-11; Eric M. Edi, "The Impact of Social Structure on Economic Outcomes" (2005) 19:1 The Journal of Economic Perspectives, 33-50.

${ }^{48}$ M. Granovetter, "Economic Action and Social Structure: The Problem of Embeddedness", 481-82.
} 
perspective seeks to offer a more nuanced analysis that is sensitive to specificity and thus avoid the implicit essentialism of many other discussions of regionalism outside Europe.

\subsection{Structure of the Thesis}

The thesis consists of seven chapters. In the second chapter, I critically appraise extant literature on ECOWAS, focusing on what these approaches do not capture: the embeddedness of the regional trade agreements in social structure of the Member States. The third chapter elaborates on the theoretical framework of the thesis by reconceptualizing regionalism as a social phenomenon. I combine three modes of sociolegal analyses: economic sociology, social conflict theory, and new regionalism theory to interrogate the complex international, regional, and national factors that shape the implementation of the ECOWAS Treaty. In the fourth and the fifth chapters, I analyze the ECOWAS Establishing and Revised ECOWAS Treaties respectively. Using the text of the treaties as a point of departure, I demonstrate how emerging cooperation and legal arrangements are influenced by socio-political contexts. The sixth chapter focuses on how the shift to human rights in 2005 reflects the fact that the treaties are embedded in a social and political context that has seen the ECOWAS Court of Justice partially repurposed from a traditional trade liberalization and economic integration-enhancing court, with an original jurisdiction focused on interpreting disputes arising from the Community treaties, to a human rights court. The final chapter concludes the thesis by synthesizing the key insights of the thesis. It examines the implication of reconceptualizing regionalism as a social phenomenon and draws the following conclusions: i) the dominant analysis of ECOWAS, especially in the first era, as a failure 
needs to be reconsidered in the broader historical and political context; ii) traditional analysis of compliance or effectiveness needs to be reconceptualized or broadened to capture the implementation techniques of ECOWAS, and indeed other regional economic cooperation schemes in Africa; iii) the impact of power dynamics, geo-political, and social conflicts on the implementation of the treaties needs more empirical analysis to deepen our understanding of the roles of regional hegemons; vi) the impact of colonial legacies and the continuing role of former imperial powers that continue today, albeit in other forms, and understanding how they permeate the regions today, particularly from the francophone West African perspective, would shed more light on some of the other challenges in the implementation of the treaties; v) the phenomenon of regionalism in ECOWAS is beyond trade liberalization; and finally vi) theoretically, regional cooperation in ECOWAS is best understood as a creative, hybrid mix of neoliberalism and ideas of a (new) developmental state phenomenon forged by states at the periphery of the global economy. 


\section{Chapter 2}

\section{Contemporary Understandings of Regional Economic Cooperation in Africa: ECOWAS}

This literature review critically examines important contemporary legal works on regional economic cooperation in Africa. It explicates the limitation of these current understandings of the regional economic communities in that they do not adequately capture the embeddedness of the implementation of ECOWAS in the historical, political, economic, and social relations of the members. The chapter contends that the literature of ECOWAS will be further enriched and blind spots illuminated by integrating a sociolegal approach with insights from International Relations on new regionalism.

\subsection{Formalism and Flexibility in African Regional Trade Agreements}

This analysis focuses on three books by some of the foremost scholars of regional economic cooperation in Africa. ${ }^{1}$ An important factor that emerges from this review is the limitation of legal formalism as the sole lens for understanding the implementation of African regional economic cooperation schemes. While the books acknowledge the importance of the social, historical, political, and economic factors to an effective regional economic cooperation, other than James Thuo Gathii's work that makes the case for these treaties as flexible legal regimes, none of the books rigorously engage in a sustained analysis of the influence of these non-legal factors on the implementation of the

\footnotetext{
1 James Thuo Gathii, African Regional Trade Agreements as Flexible Legal Regimes (Cambridge: Cambridge University Press, 2011); Richard Frimpong Oppong, Legal Aspects of Economic Integration in Africa (Cambridge: Cambridge University Press, 2011). For my reviews of these books, see respectively (2013) 112:446 African Affairs, 157-59; (2015) Journal of International Economic Law, 1-4. Also see, Kofi Oteng Kufuor, The Institutional Transformation of the Economic Community of West African States (Routledge, 2006)
} 
treaties. In this regard, the thesis's focus on how socio-political contexts shape the performance of ECOWAS provides an important contribution to our understanding of the conundrum in ECOWAS.

In his examination of the Legal Aspects of Economic Integration in Africa, Oppong seeks to insert the legal narrative "at the forefront of discussions on economic integration in Africa." ${ }^{2}$ In his earlier work, he bemoans the dearth of legal inquiry on African regional economic integration schemes, noting that it has remained at the margins while economic and political analysis dominated the literature. In taking on this gap, he develops a "relational issues thesis" to regional economic integration in Africa. ${ }^{3}$ Oppong draws on various principles in private and public international law as well as constitutional law in harnessing the theoretical foundation for his study of the legal aspects of regional economic integration. A novel contribution of his work is the examination of the private international law and conflict of laws challenges to African regional economic integration. ${ }^{4}$ Customary international law, he argues, has a role to play in international economic law and by extension, regional economic integration. Against this background, "a robust legal framework for successful integration" must look beyond strict "“legal

\footnotetext{
${ }^{2}$ Oppong notes further that legal nature of the obligations created by the [constitutive] treaties [of regional economic organizations] and other community laws, issues surrounding the integration of the community law into member states' legal systems, the relation between states - as well as between the communities - form the subject matter of...the book. Legal Aspects of Economic Integration in Africa, 29.

${ }^{3}$ Oppong, Legal Aspects of Economic Integration in Africa.

${ }^{4}$ Another scholar who has drawn on public international law in studying ECOWAS is Sunday Ajulo. See Sunday Babalola Ajulo, "The Economic Community of West African States and International Law" (1989) 27:02 Journal of Modern African Studies, 233-50; Sunday Babalola Ajulo, "Sources of the Law of the Economic Community of West African States (ECOWAS)" (2001) 45:1 Journal of African Law, 73-96.
} 
measures' and focus on the broader notion of relations between legal systems, namely those of the community and member states, international and regional systems."

Underlying this analysis is the implicit idea that a high degree of legal integration or legal formalism is essential to the effectiveness and performance of regional economic integration schemes in Africa. ${ }^{6}$ In other words, an effective economic integration scheme involves intricate interaction between states as parties, their national laws and legal systems, as well as other institutions concerned to achieve a common economic goal. Striking a balance amongst competing national and regional economic objectives, especially, in the context of developing countries has been a perennial challenge for African regional economic communities. The process, Oppong argues, creates "a complex web of relations in which the principal actors are the community, member states, individuals and other international organizations."7

Achieving optimal performance of economic integration schemes is the outcome of a conscious process for structuring and managing the relationship among Member States of a regional economic community. Oppong refers to this process as the relational approach: the product of properly structuring and managing "within well-defined legal frameworks...relations among states, legal systems, laws and institutions." ${ }^{8}$ Structured relations refer to legal frameworks that define the interconnection between community and national laws; identify the ways for implementing community law in member states;

\footnotetext{
${ }^{5}$ Oppong, Legal Aspects of Economic Integration in Africa, 36.

${ }^{6}$ Ibid., 10; also see M. Ewing-Chow, "Culture Club or Chameleon: Should ASEAN Adopt Legalization for Economic Integration?" (2008) 12 Singapore Yearbook of International Law, 225.

${ }^{7}$ Oppong, Legal Aspects of Economic Integration in Africa, 30.

${ }^{8}$ Ibid, 31.
} 
outline the "respective competencies of the community and member states"; and anticipate as well as provide rules for the resolution of conflicts in three realms: laws (conflict between legal systems), norms (conflict within a legal system), and jurisdictions. $^{9}$

Relational issues arise from the "legal interactions among community, national, regional and international legal systems within the context of economic integration." ${ }^{10}$ The management of the relational issues looks beyond legal frameworks to soft norm approaches such as "reciprocal trust and harmonious political coexistence among member states, education on community law and objectives, building up or nurturing constituencies with interest in the integration process, accessibility" ${ }^{11}$ and free information flow.

The relational principles of economic integration also have origins in public and private international law. Oppong examines dualist and monist approaches to international law and other principles such as jus cogens and supranationalism. ${ }^{12}$ Whichever end of the spectrum one upholds, the focus of the legal framework, he argues, must not only be on the relations between a community and its member states alone, but also on the framework for the "relations among member states of the community, as well as the community's relations with legal systems outside its member states."13 In other words, it

\footnotetext{
${ }^{9}$ Ibid.

${ }^{10}$ Oppong, supra note 38, at 2.

11 Ibid.

${ }^{12}$ See Ajulo, "The Economic Community of West African States and International Law"; Ajulo, "Sources of the Law of the Economic Community of West African States."

${ }^{13}$ Oppong, Legal Aspects of Economic Integration in Africa, 36.
} 
must focus both on its internal legal order and the relationship between its laws and the legal system of its member states. This three-pronged relationship comes to the fore particularly in situations that involve the judicial enforcement of the decisions of a Community Court in the national court of a Member State or vice versa. ${ }^{14}$

Further, Oppong argues that an important condition precedent for the creation and maintenance of an effective community legal system in a regional economic community is its autonomy. In addition, other legal principles such as the supremacy of community laws, recognition and enforcement of foreign normative acts, interpretive and adjudicative relational principles, and inter-system jurisprudential communication, to mention a few, are crucial to the process. Oppong also advocates that a premium should be placed on the non-legal factors - such as education and the creation of awareness about the work of a community, mutual dependence, and the degree of socio-cultural and ethnic homogeneity of a community's citizens - that serve to strengthen community-state and interstate relations. According to him,

the social matrix within which a legal system operates is as important as its substantive contents. Socio-cultural, economic and political conditions affect the extent to which relational principles can be effectively adopted or made to operate within a community and its member states. Merely providing for relational principles in treaties-as has been done in founding treaties of many communities, will not guarantee their use or effectiveness. ${ }^{15}$

To summarize, the relational legal framework enriches our understanding of the process of achieving effectiveness in the complex and multilayered interactions of laws and various legal systems of the Member States. It is, however, wedded to legal formalism.

\footnotetext{
${ }^{14}$ See, Richard Frimpong Oppong and Lisa C. Niro, "Enforcing Judgments of International Courts in National Courts", (2014) 5 Journal of International Dispute Settlement, 344-71.

${ }^{15}$ Oppong, Legal Aspects of Economic Integration in Africa, p. 61.
} 
This form of thinking about law is similar to what Gerhard Erasmus describes as a "rulebased trade regime" - an ideal form of law that will enhance the effectiveness of these organizations. ${ }^{16}$

The challenge here is that an analysis of African regional economic communities that focuses primarily on the enforcement of the aspirations in the treaties does not capture how the schemes are influenced by the social and political contexts. Legal formalism as a sole lens of analysis is in this regard limiting. Two additional risks may be associated with this mode of analysis. First, the mainstream narrative of failure is likely to be reproduced, and second, the potential for expanding our understanding of the African regional economic integration schemes is likely to be restricted. In the latter sense, it implicitly equates the standard in these organizations to the European Union. As Oppong acknowledges, understanding the implementation and effectiveness of African regional economic communities, equal significance should be placed on the relevant political, economic, and socio-cultural conditions. Oppong's work provides an important inroad for this thesis to examine not only the implementation of the treaties in their socio-political context but also that they are simultaneously embedded in the principles themselves.

Unlike Oppong, James Thuo Gathii challenges the universalism of legal formalism as inadequate to understanding African regional trade agreements. In this regard, he offers a different and alternative analysis of African regional trade agreements as flexible legal regimes. Gathii approaches the study of African "Regional Trade Agreements" (African

\footnotetext{
${ }^{16}$ Gerhard Erasmus, "Is the SADC trade regime a rules-based system?", (2011) 1 SADC Law Journal, 1734
} 
RTAs) from a multifaceted approach that builds on both the legal and institutional efforts being made to rebuild regionalization in the continent. The author explores not only the textual commitments made in the RTAs but also "other types of instruments containing trade and non-trade agreements between and among African states, such as ministerial declarations and memorandums of understanding." ${ }^{17}$ These RTAs, he notes, must be studied not just based on the text of the treaties but also within the context of "initiatives and processes including state-society relationships that are cumulatively establishing regionalism in modern Africa." ${ }^{18}$

From this point of view, his work provides an alternative analysis of the RTAs. Specifically, he argues that they are designed as "flexible legal regimes" $" 19$ that establish unconstrained regimes of cooperation as opposed to highly legalized regimes. ${ }^{20}$ The fact that the trade agreements also embrace policy-based integration does not suggest that they eschew legalization. Although African RTAs "are established through treaty frameworks, operationally they are forums for nestling regional challenges and developing political consensus on how to cooperate." ${ }^{21}$ In other words, since the underlying economic, political, historical, and social conditions about economic cooperation in Africa differ from Europe, "where trade integration has been the result of a series of treaty commitments that also created a supranational organization to which the states transferred certain types of authority, ${ }^{22}$ it called for a different theory. The

\footnotetext{
${ }^{17}$ Gathii, African Regional Trade Agreements as Flexible Legal Regimes.

${ }^{18}$ Ibid., 13.

${ }^{19}$ Ibid., 2-3.

${ }^{20}$ Ibid., 16.

${ }^{21}$ Ibid., 24.

${ }^{22}$ Ibid, 15
} 
"flexibility" thesis meshes with the heterogeneity and diversity of African RTAs and accommodates the multidimensional cooperation of these treaties across different areas.

By conceptualizing the RTAs as flexible legal regimes, Gathii provides an analysis of the agreements on their own terms, as opposed to being "treaty regimes on a path toward becoming much like their European or North American counterparts [NAFTA]. ${ }^{23}$ For Gathii, the foundation of regionalism in Africa is built on diverse "legal regimes, religious, cultural values and norms, economic endowments, political regimes and historical heritage that contrast with the European Unions" ${ }^{24}$ and provide a vital recipe for economic integration. ${ }^{25}$ Often the obligations assumed by the Member States of regional economic communities in Africa are assumed on the understanding that "compliance will not be strictly enforced because the commitments are balanced against a variety of safety values, such as the principles of variable geometry and the equitable sharing of the benefits of regionalization., ${ }^{26}$ African RTAs thus differ sharply from their counterparts in Europe and North America, where there is much higher commitment and emphasis on compliance with the legal obligations contained in the treaties establishing them with a view to changing the behavior of the Member States. The process of continuously committing to agreements by African leaders contributes to the process of "gradually building the regime's norms and rules" and "the political will and economic investment necessary to give these norms and rules efficacy."${ }^{27}$ By focusing on the "types

\footnotetext{
${ }^{23}$ Ibid. $2-3$.

${ }^{24}$ J. E. Alvarez, "How Not to Link: Institutional Conundrums of an Expanded Trade Regime" (2001) 7 Widener Law Symposium Journal, 15.

${ }^{25}$ Gathii, African Regional Trade Agreements as Flexible Legal Regimes, 12

${ }^{26} \mathrm{Ibid}, 5$.

${ }^{27}$ Ibid, 15 .
} 
of commitments contained in the treaties" and "how the RTAs are understood by the members," 28 this critical reading of the applicability of the European integration experience to Africa directly contrasts with the mainstream view of legal formalists that African RTAs should emulate the European Union.

Gathii identifies certain features that distinguish African RTAs from the traditional regional economic integration schemes. That they are adaptations of the Vinerian model: whereas the Vinerian model was developed in an industrialized context, African RTAs are concluded by mainly agrarian and raw material producing states; ${ }^{29}$ flexible legal regimes that mirror the African context; forums of integrated development and functionally specific projects; multiple objectives; and bulwarks of self-reliance and economic independence. ${ }^{30}$ The main difference from the Vinerian model is that unlike their European counterparts, the African RTAs do not primarily seek to enhance trade and market enlargement within the regions. Rather, their peculiarity lies in the fact that they "are caught at the crossroads of seeking to overcome the defining features of separate countries whose goals encompass economic, political, social and cultural objectives, in addition to the traditional goals of trade liberalization." ${ }^{31}$ The significance this feature is reinforced by Joseph Nye's caution, cited by Gathii, that "scholars studying integration in Africa must remember the primacy of politics and not be misled by

\footnotetext{
${ }^{28}$ Gathii, African Regional Trade Agreements as Flexible Legal Regimes, 2.

${ }^{29}$ See Jacob Viner, The Customs Union Issue (New York: Carnegie Endowment for International Peace, 1950). Amongst other critics, Sloan argues that Viner's analysis is essentially static as it ignores dynamic factors. See John W. Sloan, "The Strategy of Developmental Regionalism: Benefits, Distribution, Obstacles, and Capabilities" (1971) 10:2 Journal of Common Market Studies, 138-162, 144.

${ }^{30}$ Gathii, African Regional Trade Agreements as Flexible Legal Regimes, 3-38.

${ }^{31}$ Ibid, p. 12.
} 
assumptions natural to 'developed' societies. It is important to pay attention to social, historical, and economic factors.",32

The second feature of African RTAs, according to Gathii, is the principle of variable geometry, which presupposes the simultaneous occurrence of "several processes of integration proceeding at different speeds within the same sub-region under the management of more than one integration organization." 33 In the African context, it refers to rules, principles, and policies adopted in trade integration treaties that give Member States, particularly the poorest members, policy flexibility and autonomy to pursue at a slower pace timetabled trade commitments and harmonization objectives; mechanisms to minimize distributional losses by creating opportunities; and preferences in industrial allocation among members in trade agreement preferences in the allocation of credit and investments from regional banks. ${ }^{34}$ The extent to which variable geometry enhances integration or fragmentation in regional economic communities has come under close scrutiny. ${ }^{35}$

According to its critics, variable geometry can be both integrative and disintegrative. In some circumstances, it provides a cover for Member States that are unwilling to fulfill

\footnotetext{
${ }^{32}$ See Joseph Nye, Pan-Africanism and East African Integration (Cambridge, MA: Harvard University Press, 1965), 250. Cited in Gathii, Gathii, African Regional Trade Agreements as Flexible Legal Regimes, 14.

${ }^{33}$ United Nations Economic Commission of Africa (UNECA), "On the General Scheme for Coordinating and Harmonizing Integration Activities in Africa-A Critique of the Principle of Variable geometry" ECA/UNDP/IGOs/UNSAS/VII/10, January 1993, http://repository.uneca.org/bitstream/handle/10855/14362/Bib-55871.pdf?sequence=1.

${ }^{34}$ James Thuo Gathii, "The Status of African Regional Trade Agreements" (2013) 4 European Yearbook of International Economic Law, 287-351.

${ }^{35}$ See Gerald Ajumbo, "Is Variable Geometry Leading to the Fragmentation of Regional Integration in East Africa?" 7 November 2013, http://www.afdb.org/en/blogs/integrating-africa/post/is-variable-geometryleading-to-the-fragmentation-of-regional-integration-in-east-africa-12524/.
} 
their obligations. According to the United Nations Economic Commission for Africa, a possible outcome of variable geometry might be the creation of a host of small ineffective and fragmented cooperation organizations thereby jeopardizing the "efforts being made to harmonize, rationalize and strengthen" regional economic organizations. ${ }^{36}$ This means rather than working together in the interest of regional economic development objectives, Member States seek to take advantage of variable geometry by, for example, taking steps that prioritize selected national policies at the expense of the Community objectives. The African Development Bank has also pointed out that despite being "a legitimate policy tool for realization of economic integration, [variable geometry's] current deployment...has a political approach that could lead to the fragmentation of the region. ${ }^{״ 7}$ The common sense emerging from the critics is that the application of variable geometry in African RTAs may enhance disintegration rather than integration of the regional economic communities. Unlike the 2010 East African Community Trade Agreement and the Southern African Customs Union where variable geometry has been expressly enshrined in their treaties, there is no similar express provision in the ECOWAS Treaties. ${ }^{38}$

\footnotetext{
${ }^{36}$ UNECA, "On the General Scheme for Coordinating and Harmonizing Integration Activities in Africa," 1.

${ }^{37}$ See Ajumbo, "Is Variable Geometry Leading to the Fragmentation of Regional Integration in East Africa?."

${ }^{38}$ Article 7(1)(e) (Operational Principles of the Community) of the East African Community Trade Agreement defines variable geometry as a mechanism "that allows for progression in cooperation among groups within the Community for wider integration schemes in various fields and at different speeds." See Article 7(1)(e) of the East African Community Treaty of 2010, (Last Visited 1 December 2014). Pursuant to this provision, Kenya, Rwanda, and Uganda have the rights to pursue cooperation and progress in areas of common interest, provided it is done within limits allowed by the overall integration process. Also see Elisa Tino, "The Variable Geometry in the Experience of Regional Organizations in Developing Countries" (2013-2014) 18 The Spanish Yearbook of International Law, 141-62.
} 
Further, unlike other scholars that conceptualize the overlapping membership as directly linked to the ineffectiveness of the regional economic communities, Gathii argues that it reflects Africa's diversity and that "multiple RTA memberships illustrate flexibility or open-door membership that African RTAs offer. ${ }^{, 39}$ Also, overlapping membership of regional economic organizations is an indication that economic cooperation in Africa is driven by commonly shared ideological and political considerations by the Member States.

Frederick Söderbaum, an International Relations scholar, has also argued that overlapping membership of regional trade agreements is a strength and particular feature of economic integration in Africa. According to Söderbaum, the "seemingly ineffective overlap" in African regional organizations should not be seen as indicative of "a poor political commitment to regional cooperation. ${ }^{40}$ Rather, this "distinctive feature" of African RTAs might be "deliberate in order to increase the possibilities for rhetorical and discursive regionalism." ${ }^{41}$ Although both Gathii and Söderbaum find positivity in overlapping regionalism, they differ in the ultimate reasons and benefits of the structure. Whereas for Gathii overlapping membership offers the choice for a Member State to participate in different regional projects based on their priority, for Söderbaum Member States participate in multiple membership or regional economic communities to boost their regimes. The implication of Söderbaum's argument is that overlapping

\footnotetext{
${ }^{39}$ Gathii, African Regional Trade Agreements as Flexible Legal Regimes, 2. Gathii cautions that this feature should not be interpreted as an underestimation of the criticisms of multiple memberships, which he divided into two groups: criticism arising from the undesirable proliferation of RTAs in creating a spaghetti bowl, and, those that relate to the high transaction costs and administrative difficulties of complying with multiple Rules of Origin. Gathii, 65-66, see generally 65-85.

40 Frederick Söderbaum, "Whose Regionalism in Africa?" (2012) 1:9 Great Insights, http://ecdpm.org/great-insights/recipes-regional-integration/whose-regionalism-africa/.

${ }^{41}$ Ibid.
} 
memberships, "strengthen the status, legitimacy and the general interests of the political regime (rather than the nation-state per se), both on the [international and domestic arena]." ${ }^{42}$ It differs from Gathii's analysis in the sense that multiple members provide alternatives to pursue different types of regional projects and not simply regime-boosting exercise.

Gathii's work provides a refreshing analysis that is not wedded to the standard, legal formalist failure narrative, and his analysis makes important contributions to the field. Yet, as noted in the introductory chapter, the linear analysis of the regional trade agreements belies the reality of the trajectory of some of the regional economic communities. It is not clear whether that argument can be sustained in relation to the two eras of ECOWAS. Moreover, the "panoramic view of African RTAs" undertaken by Gathii means that further scope exists for deepening the analysis with respect to each regional economic community. ${ }^{43}$ Gathii indeed expresses the hope that "scholars and students will carry forward" such deepening analysis that examines to what extent the implementation of the individual treaties of the regional economic communities are shaped by economic, political, and historical factors. ${ }^{44}$ To probe these issues further, this thesis pursues this question with respect to the implementation of the ECOWAS Treaties

\footnotetext{
${ }^{42}$ Söderbaum, "With a Little Help from My Friends": How Regional Organizations in Africa Sustain Clientelism, Corruption and Discrimination", (2010) Gothenburg Center for Globalization and Development, 6. Regime boosting is compared to shadow regionalism, which is "an informal type of regionalism that occurs behind a façade of formal regionalism and formal diplomacy. It is driven by particular officials in the state bureaucracy, grouped with certain illegal businesspeople, who come together in order to bolster their own patronage networks and weaken those of potential challengers, and enrich themselves through informal market activities. In short, formal regionalism and political power is a business strategy." 11-12.

${ }^{43}$ Gathii, African Regional Trade Agreements as Flexible Legal Regimes, xxvii.

${ }^{44}$ Ibid.
} 
of 1975 and 1993. The point being that a more detailed and nuanced study of the implementation of ECOWAS will advance a richer understanding of the organization.

The third book under review focuses on ECOWAS. Kofi Oteng Kufuor critically examines the institutional transformation of ECOWAS arising from the Revised ECOWAS Treaty of $1993 .{ }^{45}$ Kufuor combines a New Institutional Economics (NIE) school $^{46}$ and the Ordoliberalism school ${ }^{47}$ in assessing the implications of the Revised ECOWAS Treaty. ${ }^{48}$ The NIE is an interdisciplinary enterprise that includes an amalgam of "economics, law, organization theory, political science, sociology and anthropology to understand the institutions of social, political and commercial life."49 The NIE appeals to economics as its primary language, and its aim is to interpret institutions by exploring

\footnotetext{
${ }^{45}$ See Jerry Ukaigwe, ECOWAS Law (Switzerland: Springer International Publishing Limited, 2016). A more recent discussion by Jerry Ukaigwe sheds some light on these questions in the context of ECOWAS Community Law. The book seeks to contribute to the dearth of regional economic community legal literature by synthesizing the "set of rules, standards, doctrines and principles from a plethora of ECOWAS material and Community Court judgments." Ukaigwe, ECOWAS Law, vii.

${ }^{46}$ See generally Oliver E. Williamson, "The New Institutional Economics: Taking Stock, Looking Ahead" (2000) 38 Journal of Economic Literature,, 595-613; Geoffrey M. Hodgson, "What is the Essence of Institutional Economics?" (2000) 34:2 Journal of Economic Issues, 317-329; John N. Drobak, "Introduction: Law \& the New Institutional Economics" (2008) 26 Wash. U. J. L. \& Pol’y, 1-11.

${ }^{47}$ Ordoliberalism is a theoretical school of German origin. See Peter Nedergaard, "The Influence of Ordoliberalism in European Integration Processes-A Framework for Ideational Influence with Competition Policy and the Economic and Monetary Policy as Examples," Munich Personal RePEc Archive Paper No. 52331, December 2013, 1-32, https://mpra.ub.unimuenchen.de/52331/1/MPRA paper 52331.pdf.

${ }^{48}$ See Kufuor, The Institutional Transformation of the Economic Community of West African States, supra note 23, at xv, 1-18; also see Kofi Oteng Kufuor, "Law, Power, Politics and Economics: Critical Issues Arising out of the New ECOWAS Treaty" (1994) 6 African Journal of International \& Comparative Law, 429-48.

Examples of other bodies of literature that have studied ECOWAS since its revision are: Iwa Salami and Abdourahmane Idrissa, "Out of the Penkelemes [neologism with English rendering "peculiar mess]: The ECOWAS Project as Transformation," The Global Economic Governance Programme, University of Cambridge, Working Paper Series, August 2013, GEG WP 2013/76.

49 See generally Peter G. Klein, "New Institutional Economics," 456-87, 456, http://www.cec.zju.edu.cn/ yao/uploadfile/papers/p007.pdf.
} 
questions such as, "why institutions emerge, their roles, their dynamics, their persistence, and assuming, they are inefficient, how they should be transformed." ${ }^{50}$

In addition to these two approaches as the dominant modes of analysis, Kufuor also adopts sociological and historical institutionalism in the analysis of the different factors that account for the institutional change in ECOWAS. Historical institutionalists place emphasis on the power dynamics that are associated with the operation and developments of institutions. Hence, they view "institutions as playing a mediating role in political struggles between rival groups" in order to protect "social cohesion and stability" in the organization. ${ }^{51}$ They also focus on ways that institutions inhibit development by tracing patterns of "social, political and economic behaviour over time and space." ${ }^{, 52}$ His thesis is that a NIE analysis not only provides the answer to the question of why the ECOWAS Establishing System persisted for so long but also provides a way to explain the process of change that led to the adoption of the Revised Treaty. ${ }^{53}$ For him, the process of incremental changes holds a better promise of a strengthened future for the organization in comparison to a fundamental and radical alteration of the institutions of a regional economic community.

\footnotetext{
${ }^{50}$ See Kufuor, The Institutional Transformation of the Economic Community of West African States, at 2. For a leading work on the theoretical construct of New Institutional Economics, see generally Douglass C. North, Institutions, Institutional Change and Economic Performance (Cambridge: Cambridge University Press, 1990); Douglass C. North, "The New Institutional Economics and Development," http://www2.econ.iastate.edu/tesfatsi/NewInstE.North.pdf.

${ }^{51}$ Kufuor, The Institutional Transformation of the Economic Community of West African States, 11.

${ }^{52}$ Ibid.

${ }^{53}$ Ibid.
} 
Kufuor argues that prior to its revision in 1993, the ECOWAS Establishing Treaty "failed to serve as an engine for market integration." ${ }^{54}$ As Kufuor notes, "formal and informal constraints interact to shape organizational paths. Once on a given institutional path, an organisation's decision-makers and interests obtain advantage from the 'increasing returns to the institutional matrix' and, as a consequence institutions will endure notwithstanding whether they are efficient or inefficient and even if there is an alternative path for the organization that is demonstrably more efficient." ${ }^{, 55}$ For the NIE school, institutional changes occur gradually and may only be exceptionally accelerated by a rapid turn of revolutionary effects. The institutional transformation of ECOWAS is viewed as a gradual evolution, which is consistent with the theory advanced by NIE scholars as opposed to a change initiated as a seismic occurrence within the region. ${ }^{56}$ Specifically, some of the gradual changes that the ECOWAS system has undergone cover a range of issues such as trade liberalization, military relations, free movement of persons, and monetary cooperation. Consequently, Kufuor contends that the transformation of ECOWAS through the revised treaty should be viewed as a result of the change in the constructs occasioned by the "new global and regional socio-political environments, ${ }^{, 57}$ which consists of the changing ideological constructs, daily experiences of the people of West African region, incentives, ECOWAS leaders' search for legitimacy, desire for institutional efficiency, the consequence of continuing post-

\footnotetext{
${ }^{54}$ Ibid., 12.

${ }^{55}$ Ibid., $35-36$

${ }^{56}$ Ibid., 36.

${ }^{57}$ Ibid., 12.
} 
independence enthusiasm for regional co-operation in West Africa, and subjective model that have configured overtime..$^{58}$

Kufuor also considers the reform of the ECOWAS Establishing Treaty as a litmus test to explore compliance with international law. ${ }^{59} \mathrm{He}$ examines the applicability of different theoretical approaches to compliance as a possible means to explain the legal ideas embedded in the Revised ECOWAS Treaty, contending that the analysis provides a basis for further examination of the fact that "ECOWAS policy-makers have not paid due attention to the Ordoliberal argument of economic liberalism from below as an essential to an open inter-state trading order and the role that private parties can play in this regard." ${ }^{0}$ Theoretical approaches such as the managerial model or theory of compliance,${ }^{61}$ the Transformational Approach, ${ }^{62}$ the legitimacy model,${ }^{63}$ the Rationalistic model,${ }^{64}$ and the Transnational Legal Process Model ${ }^{65}$ were examined with different levels of applicability to ECOWAS. On the one hand, Kufuor contends that the

\footnotetext{
${ }^{58}$ For analysis of the legal and institutional challenges facing African economic integration generally and ECOWAS in particular, see Iwa Akinrinsola, "Legal and Institutional Requirements for West African Economic Integration" (2004) 10 Law \& Business Review Am., 493-514; Bankole Thomson, "Legal Integration as a Key Component of African Economic Integration: A Study of Potential Legal Obstacles to the Implementation of the Abuja Treaty" (1994) 20 Commw. L. Bull., 1446-56; Bankole Thompson, "Legal Problems of Economic Integration in the West Africa Sub-Region" (1990) 2 African Journal of International and Comparative Law, 792-839.

${ }^{59}$ Kufuor, The Institutional Transformation of the Economic Community of West African States, at 60.

${ }^{60}$ Ibid.

${ }^{61}$ Managerialists argue that non-compliance with obligations is hardly a function of deliberate acts by states to violate the principles of international agreements. The model is not keen about retaliatory economic sanctions that represent the dominant way countries conduct international relations in the international economic system. See generally Ibid, 60-61.

${ }^{62}$ They suggest compliance is "best achieved if stress is placed on international regimes of which international treaties are just a subset." See Ibid., 62.

${ }^{63}$ Ibid., 63-65.

${ }^{64}$ The idea that a "state sometimes obeys international law because compliance is in its self-interest." Ibid., $65 \mathrm{He}$ argues that the impact of this theory has been felt mostly with respect to the military operations of the ECOWAS.

${ }^{65}$ Ibid., 66-67. This is characterized by four features: it is non-traditional, non-statist, dynamic and not static, and normative.
} 
Managerial ${ }^{66}$, Legitimacy ${ }^{67}$ and Rationalistic models are embedded in the Revised ECOWAS Treaty to different degrees. On the other hand, he dismisses the immediate applicability of the Transformational and Transnational Legal Process Models to the Revised ECOWAS Treaty although he believes that in the future, the later approach can be useful in ECOWAS. Although Kufuor invokes various theories that deepen his analysis of ECOWAS, they differ from the interrogation of the implementation conundrum that this thesis undertakes.

While the three contributions discussed above enrich our understanding of the legal aspects of regional trade agreements, they simultaneously explicate other possible areas where research on Africa's regional economic communities is lacking. The three scholars agree that the context of regionalism in Africa is different from that in the EU. However, while Gathii and Oppong make important general claims with respect to regional economic integration in Africa broadly, they do not engage systematically with ECOWAS in the way this thesis proposes. And although Kufuor does, the NIE approach its primary economically oriented. The central message of the NIE is that institutions matter for economic performance and that transactions are costly. It therefore differs in relation to its prognosis in comparison to the socio-legal approach through which I conduct this research.

\footnotetext{
${ }^{66}$ Ibid., 61. In response to the question of whether the new ECOWAS Treaty was influenced by the Managerialist thesis, Kuffuor responds affirmatively, although with some qualifications. He notes that "a look at the language of the [Committee of Eminent Persons] reinforces the impact of Managerialism on the 1993 treaty."

${ }^{67}$ Some features that include textual determinacy as a means of enhancing compliance, symbolic validation, rule coherence-i.e., how general is the application of rules, and adherence distinguish the Legitimacy model. According to Kufuor, "these characteristics have shaped the institutions under the 1993 Treaty." Kufuor, Kufuor, The Institutional Transformation of the Economic Community of West African States 63.
} 
Although these works advance our knowledge of African regional economic integration schemes, there remains considerable room to deepen the analysis of the implementation conundrum of the treaties. Such analysis would focus on a historical evolution of individual regional economic integration and through other theoretical approaches examine how their implementation is being shaped by the political, social, historical, and economic conditions. Such an approach would provide alternative insights to the legal formalist approaches of the mainstream literature. As Shaun Breslin, Richard Higgott, and Ben Rosamond argue, most of the approaches that take legal formalism as the sole lens for the analysis of ECOWAS reflect an inherent "teleological prejudice informed by the assumption that 'progress' in regional organization is defined in terms of EU-style institutionalization." 68

\subsection{Synthesis of the Emerging Implementation Conundrum}

There remains significant scope for studying each of the regional economic communities in order to understand the unique challenges and contexts that shape their implementation as a social phenomenon. The premise is that while the overall goal of economic development and trade liberalization of these organizations might be similar, the implementation and practice of the Member States' post-adoption of the treaties do differ. They differ because they are conditioned by different Member State challenges, the complexity of social relations, civil war, social conflicts, and changing international and national socio-political factors.

\footnotetext{
${ }^{68}$ See, Shaun Breslin, Richard Higgott, and Ben Rosamond, "Regions in Comparative Perspective" in New Regionalisms in the Global Political Economy, ed. S. Breslin, C. Hughes, N. Philips, and B. Rosamond (London: Routledge, 2002), 11.
} 
First, in the case of ECOWAS, the implementation conundrum arises as a result of conflicts between ECOWAS's legal regime and those of the Member States, the challenge of surrendering national sovereignty, supranationalism, the role of regional hegemons, the francophone and anglophone division in the region, and the legacies of colonialism. The historical account of these factors in each of these economic communities is under-represented in the literature on African regional economic communities. Undertaking an individual analysis of the regional economic communities does not mean that one turns a blind eye on the inherent diversity of the African continent. Instead, such an approach deepens the analysis of each organization with the body of evidence that provides the relevant context. It would also avoid the temptation of generalizing or projecting to the entire continent outcomes of studies from a particular regional organization. Such an approach holds the promise of teasing out the unique challenges of each region and regional economic group without undermining or underestimating the fact that some similarities exist between these organizations in relation to the challenge they face. For example, the differences in the implementation of the treaties can be seen in the transformation of the different regional courts from a focus on traditional economic cooperation to the contemporary emphasis on enhancing human rights. This thesis undertakes the analysis in the context of ECOWAS in chapter 6.

Secondly, the implementation conundrum can be explained based on the fact that the aspirations of Member States to the regional trade agreements extend beyond trade. Today, the multidimensional themes in African regional economic cooperation treaties 
extend to human rights and the use of the regional courts for various cases that are not focused on economic integration. The actors have also expanded with the active involvement of citizens and civil society now commonplace. The current literature on ECOWAS has not sufficiently dealt with the socio-political contexts that make possible the rise of non-state actors in ECOWAS as well as how these factors shape the implementation conundrum of the ECOWAS Treaties.

Third, the literal textual interpretation of regional economic treaties is limited in explicating the context of the implementation of these agreements. The question is, how we broaden the research to account for the unconventional ways that they continue to exist and be implemented. For example, two historical factors that are crucial to understanding the implementation of ECOWAS are the struggle for independence and the defence against neo-colonialism on the one hand, and the challenge of a continually globalizing order on the other hand. Understanding ECOWAS requires a deep understanding and integration of the historical context, social conflicts, power relations, and regional socio-economic and political exigencies of the region that shape its implementation. The hegemonic and enduring ideas of colonialism that influenced the political, economic, and legal thought on regionalism in early independent Africa also matter for such an analysis. For example, one must ask to what extent colonialism/globalized ideas about law vis-à-vis the fear of neocolonialism influenced modes of legal thought about trade agreements/regional integration as a means of achieving development in ECOWAS Establishing Treaty and their implementation? The answer to this question will assist in probing and understanding ECOWAS 
implementation conundrum while also illuminating the limitations of the failure critique. Certainly, existing research shows that the Eurocentric idea of regionalism as underpinned by legal formalism is not absolute, and its pretentious claim to universalist application is fraught. ${ }^{69}$

To address the implementation conundrum in the literature on regional cooperation in ECOWAS, this thesis combines socio-legal approaches and insights from International Relations scholarship on new regionalism. This theoretical approach distinguishes the thesis from the existing body of works on regional economic communities in ECOWAS. In recent times, International Relations scholarship has focused on developing literature on regionalism that foregrounds the uniqueness of the African experience and its contribution to broader regionalism scholarship. In thinking about regionalism in Africa, critical International Relations scholars such as Hentz, Boas, and Grant argue that many "ruling regimes and political leaders in Africa engage in symbolic and discursive activities - praising the goals of regionalism and regional organizations, signing cooperation treaties and agreements, and taking part in 'summitry regionalism'—while remaining uncommitted to, or unwilling to implement, jointly agreed policies." ${ }^{70}$ The thesis probes such critique in relation to ECOWAS with a view to understanding the economic, political, and social aspects of ECOWAS. Indeed as John Jackson observes,

\footnotetext{
${ }^{69}$ For example, in the context of financial donor relationships from Swedish government, a recent report suggests that instead of replacing a top-down with a bottom-up strategy, the Swedish government should adopt "a flexible approach, which in various ways systematically synchronises national and regional support and at the same time involves private market and civil society actors." See Fredrik Söderbaum, Hanna Skansholm, and Therese Brolin, "From Top-Down to Flexible Cooperation: Rethinking Regional Support for Africa," The Nordic Africa Institute, Policy Note 3, $2016,7$.

${ }^{70}$ Fredrik Söderbaum, "What's Wrong with Regional Integration?" 8. Also see Grant J. Andrew and F. Söderbaum, eds., The New Regionalism in Africa (Aldershot: Ashgate, 2003); James J. Hentz, and Morten Boas, eds., New and Critical Security and Regionalism: Beyond the National State (Aldershot: Ashgate, 2003).
} 
"international trade relations in the world today... are a very complex mix of economic and governmental polices, political constraints, and above all an intricate set of constraints imposed by a variety of 'rules' or legal norms.",71

Further, a socio-legal approach offers an alternative basis for thinking and understanding the organization's treaties in ways that are different from perspectives that analyze the organization through the prism of classic European economic integration theories and comparative advantage ${ }^{72}$ that scholars have identified as limiting for the study of their African counterparts. ${ }^{73}$ The reconceptualization of regionalism in ECOWAS as a social phenomenon will capture the complex, multipurpose, and fluid set of ideas that have influenced the organization at different times.

\footnotetext{
${ }^{71}$ John H. Jackson, The World Trading System: Law and Policy of International Economic Relations (Cambridge/London: The MIT Press, 1989), 299.

${ }^{72}$ Söderbaum, "What's Wrong with Regional Integration?" 3.

${ }^{73}$ See Ibrahim Gambari, Political and Comparative Dimensions of Regional Integration: The Case of ECOWAS (Humanities Press International, 1991). (Gambari warns that the "received theories" must be evaluated in order to determine their relevance in Africa.). Also see James Thuo Gathii, African Regional Trade Agreements as Legal Regimes (Cambridge: Cambridge University Press, 2011).
} 


\section{Chapter 3}

\section{Towards a Socio-Legal Analysis of the Economic Community of West African States}

This chapter sets out the theoretical and methodological framework for the ensuing empirical analysis of ECOWAS. The thesis adopts a socio-legal approach, combined with International Relations' insights on new regionalism, to analyze the question: How has the implementation of the ECOWAS Treaties been shaped and influenced by changing historical, economic, and political conditions?

A socio-legal approach reconceptualizes ECOWAS as a social phenomenon that is embedded in the international economic and socio-political developments, the social relations and social structure of the West African region generally, and ECOWAS Member States in particular. ${ }^{1}$ I use a socio-legal perspective as part of the movement that opens law to the social sciences in order to understand the context in which law is practised and implemented. Unlike abstract speculations about the nature or the meaning of legal ideas, the social phenomena of law relate its enquiries to the historical, economic, social, and political experiences of the subject of study, how they change, and how the specificity of contexts shape legal meaning. A socio-legal approach to law unmasks law's character and improves the quality of legal analysis that is undertaken. If we are to fully understand regional economic communities in Africa, and ECOWAS in particular, we

\footnotetext{
${ }^{1}$ I acknowledge the inspiration of Clair Gammage's work that combines these approaches in "(Re)conceptualising International Economic Law: A Socio-Legal Approach to Regionalism," in SocioLegal Approaches to International Economic Law: Text, Context, Subtext, ed. Amanda Perry-Kessaris (New York: Routledge, 2013), 64-76.
} 
must reach beyond the discipline of law to other social sciences such as political science, sociology, history, and anthropology. ${ }^{2}$ To reconceptualize regionalism as a social phenomenon, I draw insights from socio-legal analysis, especially as it relates to economic sociology, social conflict theory, and new regionalism theory. ${ }^{3}$ Together, they expose the limitation of legal formalism and provide an alternative theoretical lens for the study of ECOWAS.

\subsection{Legal Formalism}

In this section, I demonstrate the limitation of legal formalism for the broad understanding of the implementation of the ECOWAS Treaties. Legal formalism underpins the mainstream analyses of the implementation of ECOWAS Treaties. Formalism is used in this thesis in-strict-reference to a strand of legal positivists' conception of law. ${ }^{4}$

As it applies to regional trade agreements, legal formalists interpret the terms of treaties concluded by Member States as "gapless" or complete codification of the rules and norms that apply to regulate international trade. According to Duncan Kennedy, "[i]nterpretation positing gaplessness requires the interpreter to apply in every case, according to their meanings, the legal norms he or she can derive textually, conceptually,

\footnotetext{
${ }^{2}$ See Amanda Perry-Kessaris, "What Does It Mean to Take a Socio-Legal Approach to International Economic Law?" in Socio-Legal Approaches to International Economic Law: Text, Context, Subtext, ed. Amanda Perry-Kessaris (New York: Routledge, 2013), 3-18, 6.

${ }^{3}$ Gammage, "(Re)conceptualising International Economic Law: A Socio-Legal Approach to Regionalism"; in Socio-Legal Approaches to International Economic Law: Text, Context, Subtext, ed. Amanda PerryKessaris; Perry-Kessaris, "What Does It Mean to Take a Socio-Legal Approach to International Economic Law?." in Socio-Legal Approaches to International Economic Law: Text, Context, Subtext, ed. Amanda Perry-Kessaris

${ }^{4}$ See Brian H. Bix, "Legal Positivism" in Blackwell Guide to Philosophy of Law and Legal Theory, ed. Martin P. Golding and William A. Edmundson (Malden, MA: Blackwell, 2005), 29-48.
} 
or through precedent; it categorically forbids reference to purposes and policies." black-letter strict legal approach starts with law and remains its substantive focus to the exclusion of all other contexts. ${ }^{6}$

This conception of legal formalism is similar to what Gerhard Erasmus describes as a "rules-based trade" regime that is distinguished by peculiar substantive and formal qualities such as established through an international legal instrument-as may be supplemented by protocols, directives, etc.—and enforced by all Member States; clearly delineated relationship between national and community laws; ${ }^{7}$ legal arrangements should be backed with requisite institutions "endowed with the powers and the independence required to be effective and to act on behalf of the collective."8

Legal formalism's assumption of compliance with traditional regional trade agreements does not mesh with the reality of African societies. ${ }^{9}$ It belies their heterogeneity and is akin to the colonial laws of the late 1960s and early 1970s that were promulgated by colonial states without concern for the socio-political and cultural realities of the colonized. Much of this approach towards law continued in the post-colony,

\footnotetext{
${ }^{5}$ Duncan Kennedy, "Legal Formalism" in Encyclopaedia of the Social and Behavioural Sciences, ed. Neil J. Smelser and Paul B. Baltes vol. 13 (Elsevier, 2001), 8634-38, 8635, [Emphasis mine]; also see Malcolm M. Feeley, "The Concept of Laws in Social Science: A Critique and Notes on an Expanded View" (1976) 10 Law \& Soc'y Rev., 501.

${ }^{6}$ For an analysis of the precedents in investment agreements between African and Canadian countries, see Anthony VanDuzer, "Canadian Investment Treaties with African Countries: What Do They Tell Us about Investment Treaty Making in Africa?" (2017) 18 Journal of World Investment and Trade, 556-84.

${ }^{7}$ This echoes Oppong's relational approach to the management of the legal relations between national and community laws discussed in chapter 2 .

${ }^{8}$ Gerhard Erasmus, "Is the SADC Trade Regime a Rules-Based System?" (2011) 1:1 Southern African Development Community Law Journal, 17-35, 20-21.

9 "Colonial laws are laws for a special purpose to govern situations that were regarded as exceptional. They were intended to enable optimal extraction of value from foreign territories while disciplining populations that were felt as inferior and dangerous." See generally Martti Koskenniemi, "Colonial Laws: Sources, Strategies and Lessons?" (2016) 18 Journal of the History of International Law, 248-277, 251.
} 
notwithstanding the fact that these countries have different traditions of law. To the extent that the legal formalist approach to law seeks meaning independently of the context within which they were developed, it is limiting for the understanding of the broad implementation of the regional trade agreements. As a result, interpretations that are premised primarily on legal formalism will lead to a judgment of failure on ECOWAS. Conversely, an interpretation that takes into account the socio-political factors at the international, regional, and national levels will lead to a different assessment that is not a straightforward failure.

Every argument for formalism has an equal opposite that privileges flexibility in law and accounts for context. ${ }^{10}$ Although stated in the context of law and development studies, Kerry Rittich's observation is relevant here:

[T]he ways in which myriad social and economic norms, rules, and institutions may affect the realization of different social objectives are likely to be vastly ignored by those, including economists, who focused on their efficiency-enhancing properties. Or the complex and cross-cutting effects of legal rules and other norms may simply be invisible to those who are unable to adequately assess the variety of outcomes that legal rules can generate in different social and institutional contexts, their interaction with other normative orders, and the conflicting ways that they can be interpreted and adjudicated over time. ${ }^{11}$

In other words, regional trade agreements may provide different outcomes, depending on the socio-political contexts of their implementation. As Brian Tamanaha argues, there can be no standard formula for law because every legal context in every society involves a unique constellation of forces and factors, "context matters, local conditions are crucial,

\footnotetext{
${ }^{10}$ Duncan Kennedy, supra note 1. Also see, Duncan Kennedy, "Three Globalizations of Law and Legal Thought: 1850-200", in The New Law and Economic Development: A Critical Appraisal, ed. David M. Trubek and Alvaro Santos (Cambridge: Cambridge University Press, 2006), 19-73.

${ }^{11}$ See Kerry Rittich, "The Future of Law and Development: Second-Generation Reforms and the Incorporation of the Social," in The New Law and Economic Development: A Critical Appraisal, ed. David M. Trubek and Alvaro Santos (Cambridge: Cambridge University Press, 2006), 203-52, 249.
} 
[and] circumstances on the ground shape how things work." ${ }^{12}$ Legal institutions are subject to their peculiar histories and surrounding social and economic forces that led to their formation. ${ }^{13}$

That law is a social phenomenon means that it should not be viewed as static. Rather it is constitutive, changing, and embodies fundamental principles that reflect and shape the values of the society. The point is not to disregard rules as irrelevant; rather, it is to seek ways of understanding how they work as standards of behaviour while simultaneously interacting with their social context. ${ }^{14}$ In other words, the effectiveness or otherwise of regulation through regional trade agreements in a social field should not, therefore, be assumed. ${ }^{15}$ As Celine Tan aptly puts it, "the self referential lens of formalist legal theory focusing on purely textual and interpretation of international rules and institutions fail to account for their contemporary context....It is only with the aid of a socio-legal eye that we can capture the constitutive function of law, especially how law influences modes of thought, which in turn shapes the conduct of legal actors."16

A socio-legal approach to the study of international economic law enables us to both

\footnotetext{
${ }^{12}$ Brian Tamanaha, supra note 67, at 219. Also see David Kennedy, "The Rule of Law, Political Choices, and Development Common Sense", in The New Law and Economic Development: A Critical Appraisal, ed. David M. Trubek and Alvaro Santos (Cambridge: Cambridge University Press, 2006), 95-173.

${ }^{13}$ Brian Tamanaha, Realistic Socio-Legal Theory: Pragmatism and a Social Theory of Law (Oxford: Clarendon Press, 1999).

${ }^{14}$ See, D. J. Galligan, Law in Modern Society Clarendon Law Series (Oxford: Oxford University Press, 2007), 47-58.

15 "Within legal scholarship, an orientation towards the social context of the law can thus, first and foremost, be found in the twentieth century tradition of legal realism, which, notably, furthers the encounter between law and the (other) social sciences." See Sabine Frerichs, "Law, Economy and Society in the Global Age: A Study Guide," in Socio-Legal Approaches to International Economic Law: Text, Context, Subtext, ed. Amanda Perry-Kessaris (New York: Routledge, 2013), 36-49, 40.

${ }^{16}$ Celine Tan, "Navigating New Landscapes: Socio-legal Mapping of Plurality and Power in International Economic Law," in Socio-Legal Approaches to International Economic Law: Text, Context, Subtext, ed. Amanda Perry-Kessaris (New York: Routledge, 2013), 26.
} 
discern and appreciate the significance of two key related trends: first, the existence of emergent sites of normative authority for international economic rules and regulation outside the traditional interstate system; and second, the shifting modalities of power in international economic governance that enable dominant actors to embed and globalize their models of economic organization. Advancing "from a critique of positive law characterized by legal formalism, an important assumption that underpins socio-legal studies is that there is a distinct realm of law demarcated by immanent processes that exist in engagement with the wider social realm characterized by socio-historical processes." ${ }^{17}$ To reconcile the tensions inherent in regional economic cooperation treaties, as well as mapping the wider impact of social, economic, and political relations, it requires the kind of contextualization that can only be effectively achieved by using a socio-legal approach to law. In the next section, I analyze and elaborate on what it means to reconceptualize regionalism as a social phenomenon.

\subsection{Reconceptualizing Regionalism as a Social Phenomenon}

In denouncing the sole reliance on the text of treaties by legal formalism, socio-legal scholars argue that law is not limited to statutes, judicial decisions, and administrative regulations. ${ }^{18}$ Law, they say, "cannot be understood without its historical, cultural, and social "context." 19 The texts of the ECOWAS Community comprise the ECOWAS Treaties, protocols, resolutions, and declarations adopted by the Member States. There is,

\footnotetext{
${ }^{17}$ See Radha D'Souza, "Socio-Legal Studies: Neo-Liberalism and Lessons from India's Legal Innovations" (2005) 14 Social and Legal Studies, 487-513, 489.

${ }^{18}$ C. Cownie and A. Bradney, "Socio-Legal Studies: A Challenge to the Doctrinal Approach," in Research Methods in Law, ed. D. Watkins and M. Burton (Abingdon: Routledge, 2011, p. 35

${ }^{19}$ Sabine Frerichs, "Law, Economy and Society in the Global Age: A Study Guide," in Socio-Legal Approaches to International Economic Law: Text, Context, Subtext, ed. Amanda Perry-Kessaris (New York: Routledge, 2013), 36-49, 40.
} 
however, hardly any correlation between these texts and their implementation. To account for this gap, this thesis shifts the focus of analysis away from the notion that law is rooted in governmental activity, agreements or relations of Member States and "towards a recognition that law is also rooted in the projects aspirations and aspirations of actors operating in networks of community. ${ }^{, 20}$ In the context of ECOWAS, this entails looking beyond the black-letter law to other social and political occurrences in the region that are shaping the implementation of the treaties. Further, such analysis will capture the expanded catalysts or actors that are the Plaintiffs before the ECOWAS Community Court of Justice. In exploring the actors, actions, and interactions of ECOWAS Member States, it is in this sense that context matters, illuminates our understanding of the implementation of ECOWAS beyond existing analysis, and is deployed in this thesis to enrich the dominant pure and strict legal analysis. ${ }^{21}$

There is no uniform or single socio-legal research approach. Instead socio-legal approaches include diverse perspectives that consider the relationship between law, economy, and society. ${ }^{22}$ The underlying factor that unifies the different approaches is the concern to broaden our understanding of the law by integrating the wider socio-political contexts of its implementation. Socio-legal scholars envision the law as deeply embedded

\footnotetext{
${ }^{20}$ Roger Cotterrell, "Transnational Networks of Community and International Economic Law," in SocioLegal Approaches to International Economic Law: Text, Context, Subtext, ed. Amanda Perry-Kessaris (New York: Routledge, 2013), 133-50.

${ }^{21}$ Perry-Kessaris, "What Does It Mean to Take a Socio-Legal Approach to International Economic Law?." in Socio-Legal Approaches to International Economic Law: Text, Context, Subtext, 8.

${ }^{22}$ For recent publications that explore the "socio" and "legal" in socio-legal research, see generally: Dermont Feenan, ed., Exploring the 'Socio' of Socio-Legal Studies (New York: Palgrave Macmillan, 2013); David Cowan \& Daniel Wincott, eds., Exploring the 'Legal' in Socio-Legal Studies (New York: Palgrave Macmillan, 2015). A socio-legal perspective "is characterized by interdisciplinary innovation and cross-disciplinary attention to various socio-legal problems....[It involves] multiple epistemologies, methodologies, and disciplinary perspectives, unified under primarily by its understanding of law as a set of norms or institutionalized rules."
} 
in society, instead of being autonomous in relation to the actors and institutions that it is designed to regulate. It approaches law as a mode of practical analysis of social relations ${ }^{23}$ by linking the analysis of law to the social, economic, and political contexts of its implementation. ${ }^{24}$ That is, formal laws such as regional economic treaties are not gapless and can be ambiguous because of the diverse interests and objectives of the Member States that they enshrine. By their nature, these agreements are future-oriented; therefore, it is hard to imagine that they can adequately anticipate different events that may challenge the cooperation of the countries and the implementation of the agreements in the future. Further, to define regionalism as a social phenomenon challenges essentialist conceptions of the region defined solely by geographic relationship and mutual interdependence, by rethinking them as "social and cognitive constructs that are rooted in political practice." ${ }^{, 25}$ In this regard, the perception and interpretation of political actors is an integral component of both the socio-legal approach and new regionalism literature.

The implication is that law varies significantly across different social contexts. A sociolegal approach thus expands our understanding of law, and of the social interpretation of law, and clarifies the contexts in which decisions about regulation must be made. ${ }^{26}$ Viewed from this perspective, the distinctive trajectory of ECOWAS would be

\footnotetext{
${ }^{23}$ See Roger Cotterrell, Law, Culture and Society: Legal Ideas in the Mirror of Social Theory (Farnham: Ashgate, 2006), 2.

24 "Moving away from the notion of the Westphalian state, these socio-cultural theories offer an alternative model of regionalism that conceptualise trade as a social phenomenon." Clair Gammage, "(Re)conceptualising International Economic Law: A Socio-Legal Approach to Regionalism," 67.

${ }^{25}$ Peter J. Katzenstein, "Regionalism and Asia" in Shaun Breslin, Christopher W. Hughes, Nicola Phillips, \& Ben Rosamond (eds), New Regionalisms in the Global Political Economy, (Routledge, 2002) 105-118, 105.

${ }^{26}$ Cotterrell, Law, Culture and Society, 5.
} 
understood as a product of the complex international social and political contexts, social structure and practices, as well as power relations within the ECOWAS region. ${ }^{27}$

A particular strand of socio-legal scholarship that I draw on for the study of ECOWAS is economic sociology. ${ }^{28}$ Economic sociology is "an integrative effort in reconnecting law, economy, and society, both as spheres of reality and as fields of scholarly interest."29 Economic Sociologists emphasize the role of interpersonal trust among the parties to cross-border economic transactions. For them, the level of trust among the parties as opposed to the institutionalized arrangements that exist enhances the economic activities between participating parties. ${ }^{30}$ According to economic sociologists, "actors do not behave or decide as atoms outside a social context, nor do they adhere slavishly to a script written for them by the particular intersection of social categories that they happen to occupy. Their attempts at purposive action are instead embedded in concrete, ongoing systems of social relations." ${ }^{, 31}$ By situating ECOWAS in the precarious context of postcolonial Africa as evidenced in the Anglophone, Lusophone, and Francophone divisions that has bred some level of distrust, and particularly the cautionary approach of other ECOWAS Member States to Nigeria's domination in the Community, this thesis will

\footnotetext{
${ }^{27}$ M. Hirsch, "The Sociology of International Economic: Sociological Analysis of the Regulation of Regional Trade Agreements in the World Trading System" (2008) 19:2 European Journal of International Law, 277-99.

${ }^{28}$ For a genealogy of socio-legal thinking, see Sabine Frerichs, "Studying Law, Economy, and Society: A Short History of Socio-Legal Thinking" University of Helsinki, Faculty of Law, Legal Studies Research Paper Series, Paper No 19, 1-80, https://ssrn.com/abstract=2022891. (Frerichs undertook the "reconstruction of scholarship between law, economy and society to revive the redefine the "economic sociology of law." 5. Also see R. Sweberg, "The Case for an Economic Sociology of Law" (2003) 32 Theory and Society, 1-37.

${ }^{29}$ Frerichs, "Studying Law, Economy, and Society: A Short History of Socio-Legal Thinking," 5.

${ }^{30}$ M. Granovetter, "Economic Action and Social Structure: The Problem of Embeddedness," (1985) 91:3 American Journal of Sociology, 481-510, 491.

${ }^{31}$ Granovetter, p. 487; M. Granovetter, "Economic Institutions as Social Constructions: A Framework for Analysis" (1992) Acta Sociologica 35:1, 3-11; M. Granovetter, "The Impact of Social Structure on Economic Outcomes" (2005) Journal of Economic Perspectives 19:1, 33-50.
} 
demonstrate that the selective implementation of the ECOWAS Treaties along noneconomic lines is possibly a manifestation of such embedded or inherent distrust in the social relations of the Member States that cannot be adequately addressed or captured by the mere transformations to the institutions or text of the ECOWAS treaties.

Another important point that economic sociologists allude to is the role of social conflict in the conduct of economic relations. Socio-legal perspectives foreground the social conflicts of the regions they study and highlight the fact that regional schemes reinforce "the structural inequality between regional partners, with the dominant member able to protect its interests at the expense of the weaker members. ${ }^{, 32}$ This approach can describe and illuminate these complexities in innovative ways that enrich the literature on ECOWAS. ${ }^{33}$ The existing literature on ECOWAS that emphasizes the failure due to the focus on the legal texts alone does not capture these important socio-political factors that impact the relationship of the cooperating states. According to Hirsch, "[t]he social conflict conception of IEL [International Economic Law] is conscious of economic and social stratification in the international system and it is poised to unveil parallel inequalities in IEL. ${ }^{34}$ From this perspective, the interest of the regional hegemon is privileged in the economic relations of the parties.

\footnotetext{
${ }^{32}$ Tan, "Navigating New Landscapes: Socio-Legal Mapping of Plurality and Power in International Economic Law," 69. To illustrate this in the West African context, large economies such as Nigeria, and recently Ghana with abundant human and natural resources (oil), have significant economic and political advantage over other smaller countries in the region. Also see Tan, "Navigating New Landscapes: SocioLegal Mapping of Plurality and Power in International Economic Law," supra, 19-35.

${ }^{33}$ Roger Cotterrell, "Why Must Legal Ideas be Interpreted Sociologically?" (1998) 25:2 Journal of Law and Society, 171-92, 173-74.

${ }^{34}$ Hirsh, "The Sociology of International Economic: Sociological Analysis of the Regulation of Regional Trade Agreements in the World Trading System", 294.
} 
The social phenomena of law as analyzed are both empirically and systematically oriented. Empirically, the social phenomena of law is understood "through detailed examination of variation and continuity in actual historical patterns of social coexistence, rather than in relation to idealized or abstractly imagined social conditions." 35 Systematically, it is done "to broaden understanding from the specific to the general...to situate the richness of the unique in a broader theoretical context and so provide orientation for its interpretation. ${ }^{, 36}$ Sabine Frerichs elegantly puts it as follows:

By text I mean the legal text, that is, the written rules and doctrines, or what can be considered black letter law. By subtext, I refer to the moral of a legal text, that is its implied or deeper meaning. This includes the different notions of justice underlying a legal argument, which makes it necessary also to read between the lines. By context, I refer to the social context of a legal text, that is, its forceful link with reality. In this perspective, law is not a self-contained discourse, but a powerful social institution.... The categories of legal text, moral subtext and social context help to distinguish between positivist, naturalist, and historicist schools of legal thought. ${ }^{37}$

The sociological conceptualization of legal ideas as a social phenomenon "reflects law's own fragmentary and varied methodological characteristics as understood by those who participate in or are affected by legal practices...[therefore,] sociological interpretation extends legal analysis; it broadens the perspectives of legal participants." ${ }^{38}$ Through the analysis of the complex interactions of social and political relations that shape the trajectory of the organization, this thesis broadens our understanding of the implementation conundrum and opens up new vistas for addressing the normative questions relating to the effectiveness or otherwise of ECOWAS Treaties.

\footnotetext{
${ }^{35}$ Cotterrell, "Why Must Legal Ideas Be Interpreted Sociologically?," 183.

36 Ibid.

${ }^{37}$ Sabine Frerichs, "Studying Law, Economy, and Society," 9.

${ }^{38}$ Cotterrell, "Why Must Legal Ideas Be Interpreted Sociologically?," 189.
} 
To summarize, socio-legal approach transcends the strict "formalism" of the traditional legal scholars and their focus on the text (rules and institutions) of the ECOWAS Treaties by supplying a critical theoretical lens for analyzing the contemporary social function of the treaties based on the social, economic, and political contexts. The complex historical evolution of ECOWAS Member States, economic development ideas such as the structural adjustment program and the good governance proposals promoted by international institutions, social conflict in the ECOWAS region among other factors, provide important context through which the implementation conundrum in ECOWAS is interrogated to generate new insights for our understanding of ECOWAS.

To supplement the often national, state-focused approaches of legal scholarship, I integrate International Relations' perspectives on new regionalism into my analysis of ECOWAS. This provides for a rich interdisciplinary approach that incorporates both global and regional changes in political and economic factors that shaped the revision of ECOWAS as well as its implementation. Further, the combination of socio-legal approaches and International Relations scholarship offer a framework of analysis to reflect on the incorporation of themes such as human rights and environmental governance in contemporary practices of regional integration in ECOWAS. Like sociolegal researchers, recent International Relations scholarship on regionalism in Africa has been grounded in the experiences of the continent that has shaped regionalism.

\subsection{The New Regionalism Perspective to Contextualizing ECOWAS}

The resurgence of regionalism since the mid-1990s has triggered the proliferation of new 
concepts and theoretical approaches. ${ }^{39}$ In contemporary times, the discipline of International Relations ${ }^{40}$ has produced the majority of theories of regionalism in Africa. ${ }^{41}$ The new regionalism scholarship ${ }^{42}$ has advanced our understanding by responding to the changing global structure through different theories by which we might understand the practice of regionalism in Africa. ${ }^{43}$ To the extent that the new regionalism criticizes the rationalist, positivist tendencies of traditional regionalism and its poor attention to the socio-economic, political, and historical contexts of regional economic cooperation, it meshes with socio-legal approaches and is useful in capturing the diverse international contexts that deepen our analysis of the implementation conundrum of the ECOWAS Treaties. As Amitav Acharya and Alastair Ian Johnston note,

Compared to the earlier regional integration literature,..."new regionalism" viewed regionalism to be a more multifaceted and comprehensive phenomenon taking into

\footnotetext{
${ }^{39}$ See Chimelu Chime, Integration and Politics among African States: Limitations and Horizons of midterm theorizing (Uppsala: The Nordic Institute of African Studies, 1977); Tanja A. Börzel, "Comparative Regionalism: A New Research Agenda.”.

${ }^{40} \mathrm{I}$ am aware of the internal tension (regional specialization and comparative research) among IR scholars on theorizing regionalism whether in the context of European Integration or in the rest of world. Being an internal debate peculiar to IR, this chapter does no more than acknowledge it here. See Fredrick Söderbaum, "Comparative Regionalism," in SAGE Handbook of Comparative Politics, ed. Todd Landman and Neil Robinson (London: Sage Books, 2009); see also P. Schouten, "Theory Talk \#15: Peter Katzenstein on anti-Americanism, Analytical Eclecticism and Regional Powers," Theory Talks, 29 August 2008, http://www.theory- talks.org/2008/08/theory-talk-15.html.

${ }^{41}$ As opposed to being interested in the designs of regional institutions, economists question whether regionalism provides a stumbling or building block for the global liberalization of trade while political scientists interrogate the ability of regional organizations to provide governance at the regional level. See Tanja A. Börzel, Lukas Goltermann, Kai Striebinger, eds., Roads to Regionalism: Genesis, Design, and Effects of Regional Organizations (Burlington, UK: Ashgate, 2012).

${ }^{42}$ Some relevant books and articles are: Fredrik Söderbaum and Timothy Shaw, Theories of New Regionalism (New York: Palgrave Macmillan, 2004); Heribert Dieter and Richard Higgot, "Exploring Alternative Theories of Economic Regionalism: From Trade to Finance in Asian Co-operation," The University of Warwick Centre for the Study of Globalisation and Regionalisation Working Paper No. 89/02, January 2002; Daniel Sakyi and Eric Evans Osei Opoku, "Regionalism and Economic Integration in Africa: A Conceptual and Theoretical Perspective," The African Capacity Building Foundation, Occasional Paper No. 22, 2014; Peter Draper, "Rethinking the (European) Foundations of Sub-Saharan African Regional Economic Integration: A Political Economy Essay, OECD Development Centre Working Paper No. 293, September, 2010, http://www.oecd.org/dev/46013902.pdf; Jeffrey Herbst, "Crafting Regional Cooperation in Africa," supra note 5.

${ }^{43}$ Andrew Grant and Frederick Söderbaum, eds., The New Regionalism in Africa (Aldershot: Ashgate Publishing, 2003) - arguing that "conventional or problem-solving theories of regionalism do not portray accurately the overlapping processes of regionalization that continue to evolve across Africa."
} 
account the role of both state and non-state actors, as well as a whole range of political, economic, strategic, social, demographic and ecological interactions within regions. It shifted the focus away from formal institutions toward studying informal sectors, parallel economics and non-state conditions. ${ }^{44}$

Jurists have not sufficiently engaged this rich body of work as it relates to individual regional economic communities. By bringing insights on new regionalism from International Relations into dialogue with socio-legal approach, I broaden the framework for analysis of ECOWAS. In particular, the emphasis placed on the intersection between the global and the local context and the broad conceptualization of actors in regionalism beyond state-centric narratives meshes with socio-legal perspective as adopted for the study of ECOWAS in this thesis. The combination addresses the problem with the Eurocentric approaches underpinned by legal formalism that suffocate out "less sanguine and less politically correct assessments" 45 of regional integration or that "prevent the development of more general conceptual and theoretical toolboxes. ${ }^{, 46}$ Before turning to the analysis of the new regionalism and its integration into the socio-legal approach for this thesis, I discuss, briefly, old regionalism.

\subsubsection{Old Regionalism}

A series of political, economic, and social events were relevant to the rise of regional economic cooperation in Africa. The surge of regionalism in Africa during the late 1950s and 1960s cannot be separated from the struggle for political and economic liberation of these erstwhile colonies and the subsequent achievement of independence. Although

\footnotetext{
${ }^{44}$ A. Acharya and A. I. Johnston, eds., Crafting Cooperation: Regional International Institutions in Comparative Perspective (Cambridge: Cambridge University Press, 2007), 9-10.

${ }^{45}$ Söderbaum, "What's Wrong with Regional Integration?," 8; Fredrik Söderbaum and Alberta Sbragia, "EU Studies Meets the New Regionalism: What Can be Gained from Dialogue?" (2010) 32:6 Journal of European Integration, 563-82.

${ }^{46}$ Fredrik Söderbaum, "What's Wrong with Regional Integration?," 2.
} 
International Relations scholars distinguish between old and new regionalism, ${ }^{47}$ it is important to note that their general usage in the literature on regionalism is not wedded to a fixed understanding of time or period in history. ${ }^{48}$

However, there is consensus on the fact that old regionalism is top-down, strictly statecentric and loosely associated with the period between 1960 and $1990 .{ }^{49}$ These broad periods encompass the trajectory of regional economic organizations in post-colonial Africa and it is shaped by a distinctive history. ${ }^{50}$ Shaped in and by a bipolar Cold War context, old regionalism was predicated on inward looking and protectionist approaches that placed exclusive economic focus on economic integration objectives. ${ }^{51}$ Regional cooperation was also intertwined with a set of ideologies closely associated with contested notions of economic development, and in particular, modernity. ${ }^{52}$ Its theoretical foundation included federalism, functionalism, neofunctionalism, and transactionalism as well as intergovernmentalism. ${ }^{53}$ Although old regionalism was described as narrow with

\footnotetext{
${ }^{47}$ Börzel, "Comparative Regionalism," 6. According to Börzel, "there is new and old regionalism, regionalism in its first, second and third generation."

${ }^{48}$ See Raimo Vayrynen, "Regionalism: Old and New" (2003) 5 International Studies Review, 25-51. (The author examined recent literature on political, economic, and cultural regionalism; as well as the methodological and theoretical fragmentations arising from them.) Also see Wilfred J. Ethier, "The New Regionalism" (1998) 108 The Economic Journal, 1149-61. See Fredrik Söderbaum and Therese Brolin, "Support to Regional Cooperation and Integration in Africa-What Works and Why?" January 2016, 26.

${ }^{49}$ See Björn Hettne and Fredrik Söderbaum, "Theorising the Rise of Regionness" (2000) 15:3 New Political Economy, , 457-73.

${ }^{50}$ See Daniel C. Bach, "Regionalism in Africa: Concepts and Context" in Routledge Handbook of African Security, ed. James Hentz (London: Routledge, 2013), 181-89, 184.

${ }^{51}$ See Tiyanjana Maluwa, "Reimagining African Unity: Some Preliminary Reflections on the Constitutive Act of the African Union" (2001) African Yearbook of International Law, 1-38, 16.

52 Gibb, "Regional Integration and Africa's Development Trajectory," 705. See Manfred Bienefeld, "Dependency Theory and the Political Economy of Africa's Crisis" (1988) 15:43 Review of African Political Economy, 68-87.

${ }^{53}$ Fredrik Söderbaum, "Early, Old, New and Comparative Regionalism: The Scholarly Development of the Field," Working Paper, KFG The Transformative Power of Europe. No. 64, October 2015; Dr. Heiner Hänggi, "Interegionalism: Empirical and Theoretical Perspectives," 18 May 2000, Paper presented at The Pacific Council on International Policy, Los Angeles, http://www.cap.lmu.de/transatlantic/download/Haenggi.PDF.
} 
regard to "objectives and content, with a specific focus on free trade arrangements and security alliances, ${ }^{, 54}$ this position contradicts most African regional trade agreements concluded immediately after independence in the 1960s and 1970s. These trade agreements not only dealt with the traditional trade liberalization agenda but also extended to unorthodox areas of cooperation such as infrastructure provisions and regional economic development projects that cut across the transnational issues.

According to Fredrik Söderbaum, "regionalism in the developing world was heavily influenced by the structuralist tradition of economic development, pioneered by Gunnar Myrdal, Arthur Lewis, and Raúl Prebisch. In sharp contrast to the European debate, which focused heavily on regional integration, the keywords here were development, state-promoted industrialization and nation-building, first and foremost through protectionism and import-substitution." 55 The structuralist school, championed by the United Nations Economic Commission for Latin America (ECLA) under the leadership of Raúl Prebisch advanced a form of regional economic cooperation that spread across other developing countries. Calling for structural transformation, this "school shifted its focus away from economic integration as means for peace and political unification, to one of regional economic cooperation/integration as means for economic development and state-formation. The dependent variable, as well as the underlying conditions for

\footnotetext{
${ }^{54}$ Fredrik Söderbaum, The Political Economy of Regionalism: The Case of Southern Africa (New York: Palgrave Macmillan, 2004), 31.

${ }^{55}$ Söderbaum, "Early, Old, New and Comparative Regionalism," 14; also see Arturo Escobar, The Making and Unmaking of the Third World, (Princeton, NJ: Princeton University Press, 1995).
} 
regionalism, was so different that it called for a different theory, according to which Europe and the developing world were not comparable cases. ${ }^{, 56}$

Old regionalism in Africa was linked to colonialism and anti-colonialism. PanAfricanism played an important role in the intellectual history of regional economic communities in early post-colonial Africa. Pan-Africanism was not about liberation movements alone; it was also about regional cooperation. Ideologies about integration among the pan-Africanists, however, were not harmonious; rather, pan-Africanism was characterized by various heterogeneous alliances - a fact which mirrors the diversity of the continent itself. While some wanted only one continental regional organization, others wanted regional ones such as ECOWAS. The pan-Africanists stressed the importance of collective self-reliance, introverted and protectionist strategies, planned and import substitution industrialization. Notwithstanding the divergence in the panAfricanists' views about the political and economic thought in relation to regional cooperation, there was consensus on the need for the emancipation and unity of Africa, which took the form of regional blocs, as well as the need to establish an African common market. ${ }^{57}$

\footnotetext{
${ }^{56}$ Söderbaum, "Early, Old, New and Comparative Regionalism," 14 also see Adekeye Adebajo, "Two Prophets of Regional Integration: Prebisch and Adedeji," in International Development: Ideas, Experience, and Prospects, Bruce Currie-Alder, Ravi Kanbur, David M. Malone, and Rohinton Madhora, eds. (Oxford: Oxford University Press, 2014), 323-38; Adekeye Adebajo, "A Tale of Two Prophets: Jean Monnet and Adebayo Adedeji," in African Development in the 21st Century: Adebayo Adedeji's Theories and Contributions, Amos Sawyer, Afeikhena Jerome, and Ejeviome Eloho Otobo, eds. (Asmara and Trenton: Africa World Press, 2014), 77-90.

${ }^{57}$ P. O. Esedebe, Pan-Africanism: The Idea and Movement, supra note 36, at 172; see also S. K. B. Asante, Regionalism and Africa's Development, 33.
} 
Old regionalism also extends to the notion of developmental regionalism. Developmental regionalism has been incoherently used in different ways to describe different moments in the trajectory of regionalism in Africa. For example, as far back as 1971, John Sloanoriginally credited with the phrase - examined the benefits, obstacles, and capabilities of the strategy of developmental regionalism against the need for economic development in the Third World. ${ }^{58}$ According to Sloan, developmental regionalism "refers to the joint policies of economic cooperation, coordination, and integration among underdeveloped countries designed to accelerate the rate of development of both the members-states and the geographical region." ${ }^{59}$ Sloan argues that developmental regionalism serves not only to expand trade but also "to encourage new industries, to help diversify national economies, and to increase the region's bargaining power with developed nations." ${ }^{60}$ The notion of developmental regionalism appears to have been influenced by the dominant economic development idea of modernization to the extent that he argues that economic integration will accelerate the modernization process. In particular, Sloan argues that five benefits emanate for Third World countries that participate in economic integration: a means of achieving economies of scale, a more rational specialization, a means of enhancing efficiency in industry, a means of reducing the external vulnerability of the developing economies because of the hegemonic international economic order of the 1970s, and improved bargaining power of the regional members with the industrialized countries. ${ }^{61}$ Developmental regionalism's ultimate goal is the economic development of

\footnotetext{
${ }^{58}$ Sloan, "The Strategy of Developmental Regionalism," 138-62. For a recent analysis of developmental regionalism in the European context, see, Mathew Doidge, "From Developmental Regionalism to Developmental Interregionalism: The European Union Approach", NCRE Working Paper No. 07/01, July 2007.

${ }^{59}$ Sloan, "The Strategy of Developmental Regionalism," 142.

${ }^{60}$ Ibid.

${ }^{61}$ Ibid., 144-49.
} 
the Member States within a particular regional organization by providing "external incentives to help each individual member overcome its own domestic underdevelopment." ${ }^{62}$

Over forty years later, developmental regionalism returned to the forefront recently through the United Nations Conference on Trade and Development (UNCTAD) as a possible way out of the economic quagmire of African countries. ${ }^{63}$ A key difference in the underlying thinking in development regionalism as conceived by Sloan in 1971 and UNCTAD in 2013 is that despite some similarities in their ultimate economic benefits and prescription, they are informed by different theoretical ideas-classical developmental state theory and the new developmental state. ${ }^{64}$ For example, whereas Sloan emphasizes the role of states in the process of economic integration, the UNCTAD report "discusses the tools and drivers of a developmental integration agenda led by the State but with significant and active private sector participation." ${ }^{.65}$ The overlap reinforces the point about the fluidity and non-static nature of the waves of regionalism in ECOWAS. It is also a reminder that in theorizing about regionalism in the continent,

\footnotetext{
${ }^{62}$ Ibid., 149. According to Sloan, the most telling criticism of developmental regionalism is that it calls upon its members to perform at a level of efficiency beyond their present capabilities. The fundamental dilemma of developmental regionalism is that it increases the burdens upon member-states, which already bear the heavy burden of underdevelopment. Sloan, "The Strategy of Developmental Regionalism," 162.

${ }^{63}$ United Nations Conference on Trade and Development (UNCTAD), Economic Development in Africa Report 2013, Intra-African Trade: Unlocking Private Sector Dynamism (United Nations, 2013), http://www.tralac.org/images/docs/541/economic-development-in-africa-report-2013.pdf.

${ }^{64}$ See David M. Trubek, Helena Alviar Garcia, Diogo R. Coutinho, and Alvaro Santos, Law and the New Developmental State: The Brazilian Experience in Latin American Context (Cambridge: Cambridge University Press, 2013).

${ }^{65}$ UNCTAD, Economic Development in Africa Report 2013, 96. According to UNCTAD, "developmental regionalism encompasses cooperation in the area of trade, with an emphasis on the promotion of intraregional trade and integration into the global economy. It goes beyond the domain of trade per se by including cooperation in other, more ambitious areas, such as industrial policy. Emphasis is placed on implementing 'strategic' trade policies (i.e., those which include both more and less traditional policy tools, such as export promotion and selective protection) and ensuring that these are consistent with the domestic industrial policy framework of each State involved." Economic Development in Africa Report 2013, 97.
} 
scholars of regional integration "must remember the primary role of politics and not be misled by assumptions natural to developed societies. It is important to pay attention to social, historical and economic factors. ${ }^{.66}$

\subsubsection{New Regionalism}

New regionalism occurs in a completely different world order that "is marked by a deep and strong process of globalization and a re-configuration of state-society relations both of which are under the canopy of neoliberalism." ${ }^{.67}$ It is a "central aspect of the new interor transnational relations. ${ }^{68}$ New regionalism theorists are critical of the rationalist, positivistic underpinning of old regionalism "for being both 'overly concerned' with methodology and 'under-concerned' with the socio-economic circumstances and historical context of regionalism.. ${ }^{, 69}$ In this regard, its emergence was an eclectic and explorative effort to understand the phenomenon of regional cooperation in the context of economic globalization. ${ }^{70}$ Indeed, as Timothy Shaw, J. Andrew Grant, and Scarlett Cornelissen assert, "the proliferation of the 'new regionalisms' approach is, in part, a function of the appearance of new states, but also of the intensification of inequalities as a result of the exponential, uneven impacts of globalization (or globalizations), including

\footnotetext{
${ }^{66}$ Joseph Nye, Pan-Africanism and East African Integration (Cambridge, MA: Harvard University Press, 1965), 250.

${ }^{67}$ Daniel C. Bach, "Regionalism in Africa: Concepts and Context", supra note 12. "The first thoughts were developed by Björn Hettne in the mid-1980s, within a research project on 'European integration beyond the Cold War'. The New Regionalism Approach (NRA) itself was first mentioned in the mid-1990s during another of Hettne's research projects: the UNU-WIDER research project on The New Regionalism." See P. Schouten, "Theory Talk \#19: Frederik Söderbaum on the Waning State, Conceptualizing the Region and Europe as a Global Actor," Theory Talks, 1 October 2008, http://www.theory- talks.org/2008/10/theorytalk-19.html.

${ }^{68}$ Frederik Söderbaum, "Introduction: Theories of New Regionalism," in Theories of New Regionalism, A Palgrave Reader, ed. Frederik Söderbaum and Timothy Shaw (New York: Palgrave Macmillan, 2003), 1.

${ }^{69}$ See Amanda Perry-Kessaris ed., Socio-Legal Approaches to International Economic Law, 71.

${ }^{70}$ Schouten, "Theory Talk \#19: Frederik Söderbaum," 2.
} 
its cultural, social, technological, economic and financial facets." ${ }^{, 71}$ Most associated with critical international political economy (IPE), it has completely different features that include an urge for the pooling of sovereignties to tackle global challenges, open and outward oriented, comprehensive and multidimensional societal process, ontological pluralism, and part of globalization that recognizes non-state actors in the global system. $^{72}$

For my purposes, new regionalism integrates three previously separate theoretical perspectives: International Relations/IPE theories; Development theory; and Regional Integration theory. ${ }^{73}$ In this regard, the study of global order and global order changes is a distinct contribution of International Relations and IPE to social sciences and Development theory. The proponents of new regionalism integrate a variety of poststructural approaches in order to "develop a more historical, contextual, agency-oriented approach" and to garner a more comprehensive understanding of complexities and diversities of regionalism in Africa. ${ }^{74}$

New regionalism "transcends conventional state-centric and formalistic notions of regionalism and seeks to theorize, conceptualize and understand the multiplicities,

\footnotetext{
${ }^{71}$ See Timothy M. Shaw, J. Andrew Grant, and Scarlett Cornelissen, "Introduction and Overview: The Study of New Regionalism(s) at the Start of the Second Debate of the Twenty-First Century," in The Ashgate Research Companion to Regionalisms, ed. Timothy M. Shaw (New York, 2012), 1-30, 10.

${ }^{72}$ Björn Hettne, "The New Regionalism Revisited," in Theories of New Regionalism, A Palgrave Reader, ed. Frederik Söderbaum and Timothy Shaw (New York: Palgrave Macmillan, 2003), 23-24.

${ }^{73}$ Björn Hettne and Fredrik Söderbaum, "The New Regionalism Approach" (1998) 17:3 Politeia, 1-18 (pre-publication copy), 10.

${ }^{74}$ Fredrik Söderbaum, The Political Economy of Regionalism: The Case of Southern Africa, (New York: Palgrave Macmillan, 2004), 33
} 
complexities and contradictions of regionalization." 75 The approach "obviates the artificial separation of state and non-state actors associated with traditional or conventional regional approaches and recognizes that formal and informal aspects of regionalization are often intertwined." ${ }^{76}$ By so doing, the theory is adequately and broadly positioned to serve as a framework to explain the expansion of the actors in ECOWAS to non-state actors, particularly in the ECOWAS Community Court of Justice where these parties have been very active.

The point that emerges is that regionalism is a heterogeneous, diversified, multidimensional —economic, social, cultural, and political - phenomenon, taking place in several sectors and often facilitated by a variety of both state and non-state actors. It is conditioned by the unique histories of each region. Despite the appeal of the new regionalism approach, it has been criticized as deficient on historical contextualization and overemphasis on the binary between the "new" and the "old." 77 Being outward oriented, the institutions of new regionalism seek to integrate the regional bodies into the global economy. New regionalism strategies are, however, susceptible to setbacks primarily because of the "changes in the international economic environment that may result from the appearance of strongly protected trading blocs competing for control of

\footnotetext{
${ }^{75}$ Grant and Söderbaum note that their "definition of the NRA is a rather diffused school of regionalism espoused by scholars of critical and non-orthodox IR/IPE. Its origins can be traced to the United Nations University/World Institute for Development Economics Research (UNU/WIDER)-sponsored research project on the New Regionalism", 2 and 3; Jurgen Ruland and Karsten Bechle, "Defending State-Centric Regionalism through Mimicry and Localization: Regional Parliamentary Bodies in the Association of Southeast Asian Nations (ASEAN) and Mercusor" (2014) 17:1 Journal of International Relations and Development, 61-88.

${ }^{76}$ Grant and Söderbaum, 5.

${ }^{77}$ Daniel C. Bach, Regionalism in Africa, Genealogies, institutions and trans-state networks, (2016: Routledge) 25.
} 
world markets" ${ }^{78}$ or the recent surge of nationalist orders that signal a crack in the tenacity of globalization today. It is in this context that socio-legal analysis, particularly the economic sociology strand, complements new regionalism in accounting for the context of regionalism.

In the context of this thesis, new regionalism is conceived as an analytical and applied response to unequal economic, strategic, cultural, ecological, and technological globalizations; its impact on the small and weak states and the rise of non-state actors, private individuals, intergovernmental and non-governmental organizations (NGOs), as activists in regional integration. Regional economic communities should not be studied in isolation from their wider socio-economic, political, and historical context.

\subsection{Methodology}

The theoretical approach is designed to address the multifarious issues relating to ECOWAS. In as much as law is a prominent aspect of the analysis, the issues investigated in this thesis transcend disciplinary allegiances and do not lend themselves to a monolithic discipline. The thesis's methodological inspiration derives from the interdisciplinary theoretical approaches discussed above; to wit, it is empirical, critical, historical, and analytical. ${ }^{79}$

\footnotetext{
${ }^{78}$ See Horacio A. Grigera Naon, "Sovereignty and Regionalism" (1995-1996) 27 Law and Policy in International Business, 1073-1180, 1078.

${ }^{79}$ See generally Reza Banakar and Max Travers, eds., Theory and Method in Socio-Legal Research, (Hart Publishing, 2005).
} 
The thesis is empirical in the sense that it draws on the legal texts of the ECOWAS Treaties as well as the Community Protocols as the basis for the substantive analyses of the importance of context to understanding the implementation of the ECOWAS Treaties. Primary materials, such as the Final Report of the Committee of Eminent Persons that drafted the Revised ECOWAS Treaty was supplemented by secondary sourcesacademic books, scholarly articles, and other forms of publications - for the analyses of the limitation of legal formalism in explicating the implementation of the ECOWAS Treaties. In this regard, the methodology is critical. The ECOWAS Treaties are not inherent in some universal, timeless logical system; they are social constructs, designed to be implemented, and are indeed shaped by specific historical and social contexts for specific purposes to achieve specific ends.

The methodology is also historical in the sense that it interrogates the trajectory of the implementation conundrum in ECOWAS by looking backwards to the complex sociopolitical and economic contexts that necessitated not only the formation but also the implementation of the organization. To construct the role of underlying distrust in the region, I also examine the role of social conflict both from the historical and contemporary contexts. In so doing, the thesis avoids a linear analysis of ECOWAS and instead adopts a nuanced perspective on the changing socio-political factors and their impact.

Further, the methodology of the thesis is also analytical. To illuminate the relationship between the less economically endowed and the regional hegemon in ECOWAS on the 
one hand and their broader relations with hegemonic international institutions, such as those that promoted the structural adjustment program and the good governance proposals; on the other hand, I examine the role of power dynamics in their social relations. Hegemony is conceived of as "subduing and co-opting dissenting voices through subtle dissemination of the dominant group's perspective as universal and natural, to the point where the dominant beliefs and practices become an intractable component of common sense. ${ }^{, 80}$ Often, the law is complicit in entrenching hegemony because of its "ability to induce submission to a dominant worldview," 81 a situation evident in the existing international investment system. This thesis situates the study of ECOWAS as complicit in legal, political, and economic hegemonies and it analyzes the impact of the power dynamics on the implementation of the ECOWAS Treaties.

\subsection{Conclusion}

This chapter has introduced the theoretical and methodological approaches for the study of ECOWAS. It adopts a socio-legal approach and combines it with insights on new regionalism from International Relations scholarship to explicate the implementation conundrum in ECOWAS. The thesis will analyze the trajectory of ECOWAS by reading the changing contexts that shape the implementation of the treaties, and particularly, how the ECOWAS Treaties are embedded in broader socio-economic and political relations of the Member States. A nuanced apprehension of the importance of "cultural, social, economic, [historical and political] context [of a region] means understanding how legal institutions fit" into these categories and influence the implementation or functioning of

\footnotetext{
${ }^{80}$ Douglas Litowitz, "Gramsci, Hegemony, and the Law" (2000) Brigham Young Univ. L. Rev., 515 at 519

${ }^{81}$ Ibid., 516.
} 
the institutions. ${ }^{82}$ The interdisciplinarity of this socio-legal approach makes it a useful lens for the study of the complex connections between law and regional economic cooperation in ECOWAS. These issues are explored through the analytical, critical, historical, and empirical examinations that follow in the ensuing chapters.

82 See Mayeda, "Appreciate the Difference: The Role of Different Domestic Norms in Law and Development Reform," 547-98, 560. 


\section{Chapter 4}

\section{Revisiting the Economic Community of West African States Establishing Treaty}

This chapter revisits the implementation of the ECOWAS Treaty of 1975 (ECOWAS Establishing Treaty) by situating it in the complex and contradictory historical, social, economic, and political context of the 1970s and 1980s. ${ }^{1}$ The chapter challenges the mainstream analyses that have interpreted this era of ECOWAS through the conventional legal obligations compliance prism as a failure. To the extent that these analyses were primarily underpinned by legal formalism and the idea that law is gapless, focused on the trade liberalization and other treaty commitments of the ECOWAS Member States, they are unduly narrow and unable to provide the full account of the implementation conundrum of the ECOWAS Establishing era due to their inability to account for the socio-political contexts.

The implementation of treaties is not wedded to a particular understanding of law. From the creation of a treaty to abolition or cessation, it oscillates between legal formalism and flexibility. The body of rules designed by jurists to regulate the life of treaties reflects this constant ebb and flow. ${ }^{2}$ One key moment that oscillation manifests is at "the moment of its application - when the provisions of a treaty are confronted with the facts [reality and

\footnotetext{
${ }^{1}$ See Treaty of the Economic Community of West African States (ECOWAS), ("ECOWAS Establishing Treaty"), http://www.internationaldemocracywatch.org/attachments/351_ecowas\%20treaty\%20of\%201975.pdf.

${ }^{2}$ Jean d'Aspremont, "Formalism versus Flexibility in the Law of Treaties" in Christian J. Tams, Antonios Tzanakopoulos and Andreas Zimmermann (eds.), Research Handbook on the Law of Treaties, (2014: Elgar Publishing)

at 257 .
} 
context] and accordingly need to be interpreted." ${ }^{\prime 3}$ I reconceptualize regional economic cooperation in ECOWAS as a social phenomenon that is embedded in the social relations of the Community members. Social relations perforate economic relations of the members of a regional community. Instead of casting the first era of ECOWAS in strict and narrow terms of failure and success, it examines the influences of colonialism, power relations, economic inequality, and social conflict within the region and internationally on the implementation of the ECOWAS Establishing Treaty. ${ }^{4}$ Throughout the various analyses of ECOWAS Treaty provisions, I incorporate the argument that the social relations and social conflict amongst ECOWAS Members engendered a complex narrative than the dominant failure analysis represented.

\subsection{The ECOWAS Establishing Treaty}

The ECOWAS Establishing Treaty was signed in Lagos, Nigeria, on 28 May 1975 and came into force in 1976. The one-year delay was due to debates on some protocols relating to its implementation. ${ }^{5}$ According to Emeka Okolo, "West African leaders made difficult compromises by adopting a treaty that would allay the fears of Member-States and satisfy their different aspirations." ${ }^{\prime 6}$ The Preamble to the treaty provided the key

\footnotetext{
${ }^{3}$ Ibid., p. 258. The Revised ECOWAS Treaty considered in the next chapter offers a broader framework for the analysis of this third limb.

${ }^{4}$ See, A. Y. Yansane, "West African Economic Integration: Is ECOWAS the Answer?" (1977) 24:3 Africa Today, 43-59, at 51: arguing that "it is far from guaranteed that ECOWAS will result in disengagement by its member-states from [the then] present international economic structures, resulting in the reallocation of its resources toward fulfilling the needs of ECOWAS people."

${ }^{5}$ Daniel C. Bach, "The Politics of West African Economic Co-operation: C.E.A.O. and E.C.O.W.A.S" (1983) 21:3 The Journal of Modern African Studies, 605-23, 613.

${ }^{6}$ Julius Emeka Okolo, "Integrative and Cooperative Regionalism: The Economic Community of West African States" (1985) 39:1 International Organization, 121-53. Okolo analyses the "political dynamics and problems associated with ECOWAS and assesses its potential as an integrative unit and its prospects for success." 136.
} 
overriding principles leading to the formation of ECOWAS. The treaty recognized that the promotion of harmonious economic development in the region required an effective economic cooperation agenda that is rooted in "a determined and concerted policy of self-reliance."

To achieve the ultimate objective of accelerated and sustained economic development of its Member States, the ECOWAS Establishing Treaty provided for the creation of "a homogeneous society." ${ }^{8}$ The Preamble also provided that the unity among West African states is dependent upon the "elimination of all types of obstacles to the free movement of goods, capital and persons," 9 and this is paramount to the effectiveness of the organization. ${ }^{10}$ ECOWAS was designed "to remove the artificial barriers to trade and development that was a direct and unfortunate consequence of colonial occupation." ${ }^{11}$ In 1979, ECOWAS members adopted their first protocol relating to the Free Movement of Persons, Resident, and Establishment. ${ }^{12}$ ECOWAS citizens have the right to enter, reside, and establish economic activities in the territory of other Member States. The protocol

\footnotetext{
${ }^{7}$ Preamble, ECOWAS Establishing Treaty.

${ }^{8}$ Ibid.

${ }^{9}$ Ibid.

${ }^{10}$ On equality and fair distribution in development context, see Raymond A. Atugbua, "Equality, Nondiscrimination and Fair Distribution of the Benefits of Development" in in Realizing the Right to Development, Essays in Commemoration of 25 Years of the United Nations Declaration on the Right to Development, 109-116. (United Nations December 2013) http://www.ohchr.org/Documents/Issues/Development/RTDBook/PartIIChapter7.pdf.

${ }^{11}$ See Yakubu Gowon, "The Economic Community of West African States: A Study in Political and Economic Integration" (PhD thesis, University of Warwick, 1984), 24, http://go.warwick.ac.uk/wrap/4397.

${ }^{12}$ See Protocol A/P.1/5/79 Relating to Free Movement of Persons, Residence and Establishment; 1985 Supplementary Protocol A/SP.1/7/85 on the Code of Conduct for the implementation of the Protocol on Free Movement of Persons, the Right of Residence and Establishment; 1986 Supplementary Protocol A/SP.1/7/86 on the Second Phase (Right of Residence); 1989 Supplementary Protocol A/SP.1/6/89 amending and complementing the Provisions of Article 7 of the Protocol on Free Movement, Right of Residence and Establishment. For a coherent analysis of all these protocols, see Aderanti Adepoju, Alistair Boulton, and Mariah Levin, "Promoting Integration through Mobility: Free Movement under ECOWAS," http://www.unhcr.org/49e479c811.pdf.
} 
offers a three-step roadmap of five years each to achieve freedom of movement of persons after fifteen years. The first phase relates to the right of visa-free entry; phase two deals with the right of residency; and phase three concerns the right of establishment in another Member State. While phase one and two have been fully implemented, the third phase is still under implementation in most states. Article 3(2) of the Protocol provides that

[a] citizen of the Community visiting any Member State for a period not exceeding ninety (90) days shall enter the territory of that Member State through the official entry point free of visa requirements. Such citizen shall, however, be required to obtain permission for an extension of stay from the appropriate authority if after such entry that citizen has cause to stay for more than ninety (90) days.

Where a citizen does not comply with the provisions of the protocol, he or she may be expelled. In this regard, Article 11(1) provides that

[a] decision to expel any citizen of the Community from the territory of a Member State shall be notified to the citizen concerned as well as the government of which he is a citizen and the Executive Secretary of ECOWAS.

Moving on from the Preamble, ECOWAS's substantive aims cut across economic, social, cultural, and infrastructure. ${ }^{13}$ The treaty aimed to promote co-operation and development in all fields of economic activity, particularly in fields of industry, transport, telecommunications, energy, agriculture, natural resources, commerce, monetary, and financial questions as well as in social and cultural matters. ${ }^{14}$ In addition to the free movement of persons among ECOWAS Member States, it is anticipated that the economic, monetary, agricultural, and industrial policies of the region would be

\footnotetext{
${ }^{13}$ Amadu Sesay and Moshood Omotosho, "The Politics of Regional Integration in West Africa" (2011, October) 2:2 WACSERIES, pp. 1-36, p. 13.

${ }^{14}$ Art. 2(1).
} 
harmonized. Article 2(2) of the ECOWAS Establishing Treaty provides that the Community shall by stages abolish quantitative and administrative restrictions on trade among the Member States, and implement schemes for the joint development of transport, communication, energy, and other infrastructural facilities, and the development of a common policy in these fields. ${ }^{15}$

Article 4 of the Establishing Treaty created the ECOWAS institutions. From the highest organ downwards, they were the Authority of Heads of State and Government (the Authority) ${ }^{16}$ the Council of Ministers, ${ }^{17}$ the Executive Secretariat, ${ }^{18}$ the Tribunal of the Community, ${ }^{19}$ and Technical and Specialized Commissions. ${ }^{20}$ The Authority was the principal governing institution of the Community and was primarily "responsible for, and [had] the general direction and control of the performance of the executive functions of the Community for the progressive development of the Community and the achievement of its aims." ${ }^{21}$ The decisions of the Authority are binding on all institutions of the Community, and it was required to meet at least once a year. ${ }^{22}$ However, in reality the Authority met infrequently and was unable to provide the much-needed direction to drive economic integration. The Council of Ministers (the Council), the second-most important institution, consisted of two representatives of each Member State. The Council's

15 See, Article 2, para 1 of the 1975 ECOWAS Treaty, available at: http://www.internationaldemocracywatch.org/attachments/351_ecowas\%20treaty\%20of\%201975.pdf, last visited 15 November 2014.

${ }^{16}$ Article 5.

${ }^{17}$ Article 6 and 7.

${ }^{18}$ Article 8.

${ }^{19}$ Article 11 .

${ }^{20}$ Article 9. Four Technical and Specialized Commissions named in the ECOWAS Treaty were: the Trade, Customs, Immigration and Payments Commission; the Industry, Agriculture and Natural Resources Commission; the Transport, Telecommunications and Energy Commission; and the Social and Cultural Affairs Commission. See Article 4(e).

${ }^{21}$ Art.icle5(1) and (2).

${ }^{22}$ Article 5(3) and (4). 
responsibilities were to keep under review the functioning and development of the Community, make recommendations to the Authority on matters of policy directed at the efficient and harmonious functioning and development of the Community, give directions to all subordinate institutions of the Community and exercise such other powers as may be conferred upon it. ${ }^{23}$ Unless otherwise determined by the Authority, the decisions of the Council are binding on all subordinate institutions of the Community, and the Council is required to meet at least twice a year. ${ }^{24}$ The Executive Secretariat, led by an Executive Secretary, is responsible for the day-to-day administration of the Community and all its institutions. $^{25}$

Finally, with respect to dispute settlement, Article 11 established the Tribunal of the Community with the responsibility to "ensure the observance of law and justice in the interpretation of the provisions" of the treaty and to settle disputes as may be referred to it in accordance with Article 56 of the treaty. ${ }^{26}$ According to Article 56-Procedure for the Settlement of Disputes_-disputes between Member States shall be resolved amicably by direct agreement. Where this fails, the matter may be referred to the Tribunal of the Community, and the decision of the Tribunal shall be final.

The above overview highlights some of the key provisions of the ECOWAS Establishing Treaty, and the next section examines the complex socio-political contexts of its implementation. An important background context in this regard was that the havoc

\footnotetext{
${ }^{23}$ Article 6(2).

${ }^{24}$ Article 6(4).

${ }^{25}$ Article 8(9).

${ }^{26}$ Article 11.
} 
wrecked by colonialism in the region was still very fresh. This I contend fostered an environment of distrust, not only with respect to the socio-economic and political relations between the newly independent states and the West, but also among the newly independent ECOWAS members. The ECOWAS Establishing Treaty corresponds to the old regionalism as it incorporates the protectionist and import substitution industrialization techniques that distinguished the 1970s.

\subsection{Revisiting the Socio-Political and Economic Context of the Implementation of the ECOWAS Establishing Treaty}

The adoption of the ECOWAS Establishing Treaty and its implementation were deeply rooted in complex historical and geo-political contestations. With respect to its formation, the treaty was viewed as an heir to earlier unsuccessful attempts at economic cooperation among West African countries. ${ }^{27}$ Most of the organizations that preceded its eventual formation went moribund. Although a detailed account of the subsequent diplomatic steps that led to the eventual formation of ECOWAS is beyond the scope of this thesis, ${ }^{28}$ it is nevertheless important to note that its conclusion owed significant credit to the ability of the Member States to supress, if not overcome, the divisions within the region. ${ }^{29}$

\footnotetext{
${ }^{27}$ See Carol Lancaster, "ECOWAS: Problems and Prospects," CSIS African Notes, no. 4, October 10, 1982, 2, https://csis-prod.s3.amazonaws.com/s3fs-public/legacy files/files/publication/anotes 1082.pdf. "For example, an effort was made to balance the staffing and location of ECOWAS institutions between Frenchspeaking and English-speaking states. Dr. Aboubacar Diaby-Ouattara, from the Ivory Coast, was chosen as Executive Secretary of ECOWAS; the Managing Director of the ECOWAS Fund has been a Liberian, first Alexander Romeo Horton and later Robert Tubman. The Secretariat was located in Lagos, Nigeria, and the Fund was headquartered in Lome, Togo."

${ }^{28}$ See generally Gowon, "The Economic Community of West African States: A Study in Political and Economic Integration."

${ }^{29}$ See Carol Lancaster, "ECOWAS: Problems and Prospects," CSIC African Notes, no 4, October 1982, 2; https://csis-prod.s3.amazonaws.com/s3fs-public/legacy files/files/publication/anotes 1082.pdf.

"ECOWAS and the CEAO [Communauté économique de l'Afrique de l'ouest] owe a lot to each other.... The more effort the one side made, the more effort was stimulated on the other side." Also see Bach, "The Politics of West African Economic Co-operation," 605-23; Karen J. Alter, Laurence R. Helfer, and Jacqueline R. McAllister, "A New International Human Rights Court for West Africa: The ECOWAS
} 
The first point I examine here is the role of the United Nations Economic Commission for Africa (UNECA) in drafting the text of the ECOWAS Establishing Treaty. UNECA, an organ of the United Nations, was very active during this phase in the globalization of regionalism. It provided a preliminary draft ${ }^{30}$ that served as the basis for the negotiation of the ECOWAS Establishing Treaty, and some of the provisions of that draft were retained. ${ }^{31}$ UNECA's thinking was "influenced by the model of the EEC (European Economic Community) and more particularly by the long established Coal and Steel Community, both as an exercise in regional and industrial integration, and as the forerunner of the Common Market." ${ }^{32}$ Even at this early stage, there is an important inference to be drawn from this diffusion of ideas. Legal formalism as the underpinning legal idea of the European Union (European Economic Community in the 1970s) differed from the socio-political realities of the West African countries that were exceptionally concerned about protecting their hard-earned sovereignty. ${ }^{33}$ Also, whereas the European Countries acceded to regional economic integration agreements after a vicious war between its members, regional cooperation in Africa was accentuated by colonialism.

\footnotetext{
Community Court of Justice” (2013) 107:737 American Journal of International Law, 737-79, 741-42. "Francophone countries are deeply linked to France's economic and political system, whereas Nigeria and Ghana-the two largest Anglophone economies-have different capabilities and economic goals."

${ }^{30}$ See United Nations Economic Commission for Africa, "Preliminary Draft of a Treaty for the Economic Community of West Africa and Explanatory Notes," E/CN.14/WA/EC/5, 27 October 1967; also see Julius Emeka Okolo, "Integrative and Cooperative Regionalism: The Economic Community of West African States,", at 124.

${ }^{31}$ For example, Article 59 (Relations with other Regional Associations and third Countries) of 1975 Trade Agreement, provides that "Member states may be members of other regional or sub-regional associations, either with other Member States or non-Member States, provided that their membership of such associations does not derogate from the provisions of [the ECOWAS Trade Agreement," which is traceable to the draft treaty of 1967 provided by ECA. UNECA, Preliminary Draft of a Treaty for the Economic Community of West Africa and Explanatory Notes", 5.

${ }^{32}$ Gowon, "The Economic Community of West African States: A Study in Political and Economic Integration," 123.

${ }^{33}$ See also Bach, "The Politics of West African Economic Co-operation," 605-23, 613, acknowledging that ECOWAS was patterned after the European Economic Community.
} 
Specifically, the post-World War II condition that preceded the emergence of the economic integration in Europe differs significantly from colonialism that preceded the establishment of ECOWAS Community members. Until the recent fragmentation caused by Brexit, the foundational unity of the European Union, post-World War II, had not been seriously questioned.

However, despite the fact that many countries in Africa united to confront colonialism, as new states emerged in the post-colony, intra-community differences also surged. The distrust confronted by the ECOWAS Member States thus occurred at two levels: one associated with the distrust arising from external colonization, and another arising from intra-Community relations between newly independent states anxious to achieve unfettered sovereignty over their own political and economic affairs. ECOWAS provided a platform to unite in challenging the external dimension or neocolonialism as feared by the Member States. However, with the establishment of ECOWAS intra-community conflict between states resurfaced with strong consequences for the implementation of the treaty. Hence, legislating ex nihilito by adopting precedents from the EEC and UNECA ran into tension with the socio-political realities of the ECOWAS Member States in the 1970s. Further, simply adapting the trade agreements would not be sufficient for a similar level of success in their implementation, as the ECOWAS Member States lacked the requisite economic comparative advantage or economic differentiation to spur competitive trading among themselves. Most of the countries in the Community produced the same type of raw materials for export and imported processed goods in return. This practice remains so today. In such an environment, it is almost given that the 
implementation of the treaty, despite its textual similarity to the European counterparts, would lead to a different path for the Member States.

One of the primary ways that distrust manifested post-ECOWAS Establishing Treaty was in the context of the division between Francophone and Anglophone post-colonial Member States of the Community. Trust, an important element that economic sociologists identify as crucial to the coherence and implementation of a regional economic organization, was therefore lacking. ${ }^{34}$ The distrust has not abated; rather, it has exacerbated the complex power relations between the wealthy members of the ECOWAS Community and the less economically endowed members. Given the significance of trust in the social relations of the Community members and an important prerequisite to a functional and effective cooperation underpinned by legal formalism, the ECOWAS Establishing Treaty had a complex trajectory to navigate. Another important dimension to the complex and raucous social relations between Nigeria on the one hand, and the Francophone ECOWAS Member States and France on the other hand was France's support to Biafra's secessionist move that led to civil war in Nigeria. ${ }^{35}$ Although the civil war ended long before the establishment of ECOWAS, the role of France in the internal conflict in Nigeria added to the suspicion in socio-political relations not only between Nigeria and France but also with French colonies in the ECOWAS Community. Viewed against the background of colonialism, distrust, social conflict, protection of sovereignty, and the oppressive socio-economic relations in the international economic structure of the

\footnotetext{
${ }^{34}$ Mark Granovetter, "A Theoretical Agenda for Economic Sociology," in Economic Sociology at the Millennium, ed. Mauro F. Guillen, Randall Collins, Paula England, and Marshall Meyer (New York: Russell Sage Foundation, 2001).

${ }^{35}$ See Christopher Griffin, "French Military Policy in the Nigerian Civil War, 1967-1970" (2015) 26:1 Small Wars \& Insurgencies, 114-35.
} 
1970s, the ECOWAS Establishing Treaty hardly reflected the social, political, historical, and cultural context of the West African sub-region.

The ECOWAS Establishing Treaty also aspired to create a homogeneous regional community. It is not clear from the text of the treaty what a "homogeneous society" entails, but for the purpose of this analysis, I interpret the term to refer to a regional economic community styled after the then EEC after which ECOWAS was modelled. Underpinned by legal formalism, such a homogeneous community would be integrated and function under the administration of a powerful regional centre with legally binding powers.

Working with this assumption, the notion that ECOWAS Establishing Treaty aimed to create a homogeneous society runs into tension with the division in the social relations of its members as well as the stark reality of the diversity of its Member States. ${ }^{36}$ As S. K. B. Asante notes, the intention of ECOWAS Member States was "to transform their economies so as to improve the living standards of their people and to extend the struggle for political decolonization into one of economic decolonization. ${ }^{, 37}$

\footnotetext{
${ }^{36}$ Unlike the Establishing Treaty, the Revised ECOWAS Treaty acknowledged this reality in its preamble. The ECOWAS leaders accepted "the need to face together the political, economic and socio-cultural challenges of the present and the future, and to pool together the resources of our peoples while respecting our diversities for the most rapid and optimum expansion of the region's productive capacity. "See Preamble, Revised ECOWAS Treaty, http://www.ecowas.int/wp-content/uploads/2015/01/Revisedtreaty.pdf.

${ }^{37}$ See S. K. B. Asante, "Report on an Advisory Mission on Review of the ECOWAS Treaty1, [Emphasis mine]; also see Amadu Sesay, "Can ECOWAS Reinvent the Nationalists' Dream? Reflections on the Protocol on Democracy and Good Governance," in The Crisis of the State and Regionalism in West Africa, W. A. Fawole and Charles Ukeje, eds. (Dakar: CODESRIA, 2005).
} 
If the true intent was to guard against neo-colonization in the post-colony, it is difficult to simply, by the text of the trade agreement, surpass the distrust that is embedded in the social relations of the Community Members. The socio-economic relationship between France and its ex-colonies in West Africa provide an important point of illustration. As it relates to the French-speaking West African states, the anglophone ECOWAS Member States were particularly concerned with the continuing influence and interference of France in the domestic economic affairs its former colonies-Benin, Burkina Faso, Ivory Coast, Guinea Conakry, Mali, Senegal, and Togo. Nigeria, in particular, was suspicious of these ongoing relations because of the potential conflict or obstruction it might pose for her own national and regional aspirations as a regional hegemon. As it in fact turned out, the exact opposite of the quest for a homogeneous society happened as distrust between the Member States engulfed their capacity to build on their socio-economic relations for the betterment of the region. Indeed, the objective was at best aspirational, rather than enshrined in any form of political reality in the West African sub-region. By 1993, there was a reversal in the language of the treaty and a call for the mutual respect of the heterogeneous constitution of the ECOWAS region.

Further, an important mechanism through which the ECOWAS Establishing Treaty planned to achieve its economic and broader objectives was through the promotion of freedom of movement of persons and goods within the Community. The protocols guaranteeing these freedoms were among the first adopted by ECOWAS Member States. However, similar to several of the other provisions in the treaty, the mass deportation practices of the Member States differed from this text. For example, between 1983 and 
1985, Nigeria had deported as many as two hundred thousand aliens who were mostly nationals of ECOWAS Member States that had migrated to Nigeria during the oil boom. ${ }^{38}$ The measures were taken as a result of the collapse in the world petroleum price and fear that the Nigerian economy would not survive if the migration continued unabated, including by closure of borders. ${ }^{39}$

ECOWAS governments regularly closed international borders for security and political reasons or refused entry to foreign nationals on those grounds. ${ }^{40}$ As Laurence Helfer aptly observes, "unofficial barriers to cross-border travel—such as roadblocks, bureaucratic red tape, and graft by customs officials - are also commonplace." ${ }^{41}$ On the one hand, it is acknowledged that the inelegant colonial division of Africa means that some of the regional members share cultural, historical, and linguistic lineage that the partition broke. ${ }^{42}$ However, on the other hand, the emerging post-colonial states had more to do with the protection of their national boundaries and economies from influx of citizens from the other regional members. ${ }^{43}$ The social conflict and fractured social relations on movement of persons in particular and the deportations inhibited the potential for

\footnotetext{
${ }^{38}$ See "Nigeria Completes the Second Expulsion of Aliens," New York Times, 26 May 1985, http://www.nytimes.com/1985/05/26/world/nigeria-completes-the-second-expulsion-of-aliens.html; John Anarfi, Stephen Kwankye, Ofuso-Mensah Ababio, and Richmond Tiemoko, "Migration from and to Ghana: A Background Paper," Working Paper C4, December 2003, Development Research Centre on Migration, Globalisation \& Poverty, University of Sussex, Brighton.

39 "Nigeria Completes the Second Expulsion of Aliens," New York Times, 26 May 1985.

${ }^{40}$ See Laurence R. Helfer, "Sub-regional Courts in Africa: Litigating the Hybrid Right to Freedom of Movement", 15 I-CON: International Journal of Constitutional Law (forthcoming), http://scholarship.law.duke.edu/faculty scholarship/3517/.

${ }^{41}$ Ibid., 6. Also see, for example, the ECOWAS Court's first case involved a challenge by a private goods trader to Nigeria's closure of the border with Benin. The Court, whose jurisdiction at the time was limited to interstate cases, dismissed the suit. Olajide Afolabi v. Nigeria, Case No. ECW/CCJ/APP/01/03.

${ }^{42}$ Makau M. Mutua, "Why Re-draw the Map of Africa: A Moral and Legal Inquiry" (1995) 16 Michigan Journal of International Law, 1113

${ }^{43}$ Nigeria's first deportation of Ghanaians and in contemporary times; Ivorians have deported Bakassi community members who share the border with Cross River State in Nigeria.
} 
investors within the region. In the case of Nigeria, the most economically wealthy Member State, the dwindling economic fortune of the country also contributed to the hostility that led to the deportation of citizens of ECOWAS Member States. Even in these early days, it was clear that the texts of the ECOWAS Treaty and protocols faced mounting implementation challenges as adopted, as they were in tension with the economic and political realities of the relations of the Member States. Hence, despite the adoption of protocols affirming the Community member's commitment to freedom of movement of persons, the implementation of the protocol has not followed the text of the law.

Regional economic integration is intricately linked to increased trade patterns among cooperating Member States. Intra-ECOWAS trading within the Community has generally been low. ${ }^{44}$ Several reasons account for this dismal state: the colonial partition of many African countries into small, landlocked economies; most of these states are raw material producing countries with no capacity to refine the materials into finished products, hence they exported them to industrialized countries, which meant that the region traded more with developed countries. ${ }^{45}$ This meant that the gate-keeping pattern carried on after decolonization as a colonial legacy. ${ }^{46}$ Similarly, being predominantly raw material producing countries, the majority of ECOWAS Member States have not transcended this threshold into manufacturing or industrialized countries with capacity to compete in the

\footnotetext{
${ }^{44}$ Olawale E. Ogunkola, "An Empirical Evaluation of Trade Potential in the Economic Community of West African States," African Economic Research Consortium Research Paper 84, November 1998, Nairobi, Kenya, http://dspace.africaportal.org/jspui/bitstream/123456789/32056/1/RP84.pdf?1.

${ }^{45}$ See Jodie Keane, Massimiliano Calì, and Jane Kennan, "Impediments to Intra-Regional Trade in SubSaharan Africa," Overseas Development Institute, September 2010, http://www.odi.org/sites/odi.org.uk/files/odi-assets/publications-opinion-files/7482.pdf.

${ }^{46}$ Frederick Cooper, Africa since 1940: The Past of the Present (Cambridge: Cambridge University Press, 2002).
} 
international economic system. The idea here is that even if ECOWAS Member States were to take seriously the aspiration for economic integration, their economic conditions did not align with the aspiration.

The ECOWAS Establishing Treaty was, however, not just about economic integration or trade in the region. It was multidimensional and extended to security, politics, culture, telecommunications, and energy to mention a few. Generally speaking, the multidimensional focus of African regional trade agreements has been advocated as a distinctive feature. ${ }^{47}$ While this might be so, it has also been a core of the critique of these organizations that they lacked an economic focus. Without dismissing the potential merit of either of these positions, the implementation of the multidimensional cooperative themes provided in the ECOWAS Establishing Treaty indicates that the treaty is embedded in the social relations of the parties. In this regard, an important conclusion that should be drawn from its broad aims is that ECOWAS is not, stricto sensu, a purely economic or trade-enhancing regional institution. ${ }^{48}$ Instead ECOWAS exists for the overlapping social, economic, political, and other developmental aspirations of its members.

In other words, regional economic communities like ECOWAS "explore various issues and spill-over effects between such areas as security, economics, politics and culture. They are often political, intertwined with economic and security interests and are harder

\footnotetext{
${ }^{47}$ See J. T. Gathii, African Regional Trade Agreements as Legal Regimes, at 24 ("Multiplicity of Objectives: The Merits and Demerits of Nestling Non-trade Objectives in African RTAs").

${ }^{48}$ See Ajulo, "The Economic Community of West African States and International Law," 233-50.
} 
to evaluate in terms of effectiveness than are unidimensional organizations. ${ }^{, 49}$ Hence, to proceed in assessing the effectiveness of the organization solely on its economic integration performance is reductionist in that such analyses exclude and do not capture the other, equally important non-economic ways that ECOWAS Establishing Treaty has been implemented. Indeed, from a socio-legal approach, ECOWAS's beleaguered economic aspirations and the overall implementation conundrum were an overt manifestation of the underlying strain in its social relations. The political challenges that the Member States confronted in their countries provided an added dimension of complexity to the implementation of the treaty. To that extent the economic development decisions are consequences of political decisions, they overlap and should be read in tandem. If a political reason should be sought for the formation of ECOWAS, it is that economic development, like sovereignty that the Members guarded jealously, is itself an overriding political theme and preoccupies the minds of leaders within the region.

Politically, the decade between 1970 and 1980 when ECOWAS was established was marked by complex international relations in Africa and the global community at large. ${ }^{50}$ As James Gathii observes, the critics of African integration fail to "appreciate the importance of African RTAs [regional trade agreements] as frameworks for developing political consensus among their members around regional challenges, including those involving development, politics, or security." ${ }^{51}$ Similarly, Daniel Bach argues that

\footnotetext{
${ }^{49}$ See Hettne and Söderbaum, "Regional Cooperation: A Tool for Addressing Regional and Global Challenges," 179-244, 186, 190.

${ }^{50}$ Maxwell O. Chibundu, "Africa's Economic Reconstruction: On Leapfrogging, Linkages and the Law" (2003) Third World Legal Studies, 17-41.

${ }^{51}$ Gathii, African Regional Trade Agreements as Flexible legal Regimes, 24. Also see Emmanuel Kwesi Anang, "Investing in Peace \& Security in Africa: the Case of ECOWAS" (2004) 4:3 Conflict, Security \& Development, 533-42.
} 
ECOWAS's "economic aims have been largely overruled by the geo-political considerations which decisively shaped the Community's treaty." 52 I categorize the political factors that influenced the implementation of ECOWAS into two, namely, those that existed prior to the formation of ECOWAS and those created after the adoption of the treaty. I discuss these in order, starting with the political factors that predated ECOWAS.

The geo-political conflicts among the Member States that predated ECOWAS did not cease to exist but emerged in different forms by virtue of the national challenges that the ECOWAS Member States faced as independent economies who were not only engaged in economic battles with fellow members but also with the international political system. ${ }^{53}$ Among these ongoing factors, the politics of the francophone and anglophone divide within the region ranks highest. ${ }^{54}$ The division and its associated challenges reflect the British and French colonial rivalry in West Africa that threatened the formation of ECOWAS. ${ }^{55}$ In the post-colony, the strained relationship between francophone and

\footnotetext{
${ }^{52}$ Bach, "The Politics of West African Economic Co-operation," 605.

${ }^{53}$ Dr. Gilles Olakounlé Yabi, "The Role of ECOWAS in Managing Political Crisis and Conflict: The Cases of Guinea and Guinea-Bissau," Friedrich Ebert Stiftung, Peace and Security Series, September 2010, http://library.fes.de/pdf-files/bueros/nigeria/07448.pdf.

${ }^{54}$ Gowon vividly describes this in the following paragrapgh:

Where the British government, preparing for its entry into the EEC, in 1973, would welcome the prospect of ECOWAS, doubtless hoping to secure wider markets for British exports in West Africa as well as in Western Europe, the French, although anxious to expand their trade with Africa, and with Nigeria in particular, would naturally be sensitive to any proposal that might affect their privileged status within the region. Whatever the French reaction, it was clear to us, in Nigeria, that the Francophone states would be influenced, in varying degrees, by the attitude of the new administration in Paris, after 1969, while their views would to some extent reflect the changing pattern of Franco-African-relations during the early seventies. "The Economic Community of West African States: A Study in Political and Economic Integration," 213.

${ }^{55}$ See Adebayo Olukoshi, "West Africa's Political Economy in the Next Millennium: Retrospect and Prospect," CODESRIA Monograph Series, 2/2001, 7,

Although all of the countries of the sub-region signed the ECOWAS treaty and its protocols, there are several lines of division that continue to keep them apart and undermine their efforts at cooperation. Perhaps the most important of these is the one that corresponds to the lines of the
} 
anglophone West Africa manifested in the dissension between Nigeria and the Communauté économique de États de l'Afrique de l'Ouest (CEAO) on the implications of ECOWAS for the latter. According to General Yakubu Gowon,

the ties between France and Francophone West Africa were much closer than those between Britain and her former territories in the region. The Englishspeaking states had not, in colonial times, formed a single, homogeneous political and administrative unit, while they had long since been accustomed to a degree of independence, in economic as well as political matters, that was sometimes the envy of their Francophone neighbors. ${ }^{56}$

For example, two important areas of disagreement concerned the nature of the economic outlook ECOWAS would assume and the concern by francophone states that the corporate identity of the CEAO established in April 1973 would not be preserved by ECOWAS. ${ }^{57}$ After much persuasion, Yakubu Gowon noted the CEAO ministers joined ECOWAS as long as the existence of their own grouping was respected. ${ }^{58}$ Accordingly, Article 59 of ECOWAS Establishing Treaty provides that Member States may be members of other regional or sub-regional associations to the extent that their membership of such associations does not derogate from the provisions of ECOWAS

colonial partition of Africa: four of the countries are Anglophone, being former colonies of Britain and members of the British Commonwealth; two,... are Lusophone, being former Portuguese colonies; Liberia is English-speaking as it was founded with the help of the United States and has remained in the American sphere of influence; the remaining countries are Francophone, being former colonies of France and members of the French Francophonie.... Matters are not helped by the massive influence which France continues to exert on its former colonies in Wes Africa....The international geo-politics of the Francophone-Anglophone contest are all too often refracted into the West African sub-region with consequences on the will and scope for the extension of the boundaries of cross-cutting sub-regional co-operation.

${ }^{56}$ Gowon, "The Economic Community of West African States: A Study in Political and Economic Integration," 213.

${ }_{58}^{57}$ Bach, "The Politics of West African Economic Co-operation," 610-13.

58 "Since the end of the civil war in Nigeria, the Head of State, General Yakubu Gowon, had been actively engaged in promoting the formation of a West African grouping which would heal the rift between the francophone and Anglophone states." Ibid., 607. 
Treaty. ${ }^{59}$ This underlying agreement informs the continued co-existence of ECOWAS and the CEAO. Despite the conclusion of the ECOWAS Treaty, "France's geo-political and commercial interests in Francophone West Africa have fed into the language divide and have, therefore, constrained the scope for full-fledged regional co-operation." ${ }^{60}$ The point here is that the creation of ECOWAS did not halt the social conflicts that underpinned the relationship of the French and English speaking countries nor did it address the embedded power structure in the Community. ${ }^{61}$

The agreement was, however, nonetheless symbolic of a temporary agreement to enable the adoption of ECOWAS Establishing Treaty. Its actual implementation remained modulated by the social relations of the parties, which is immersed in distrust within the community. As Brian Tamanaha aptly notes, "legal institutions and cultural attitudes toward law exist inseparably within a broader milieu that includes the history, tradition, and culture of a society; its political and economic system; the distribution of wealth and power; the degree of industrialization; the ethnic, language, and religious make-up of the society (the presence of group tension); the level of education of the populace; the extent of urbanization; and the geo-political surroundings (hostile or unstable neighbors)everything about a particular society matters. Power dynamics among the elite within a society are particularly influential in shaping the operation of the law.,

\footnotetext{
59 "When the C.E.A.O. Ministers met in Ouagadougou in March 1974, they none the less asserted their readiness to belong to the new organisation, provided that the existence of their own grouping would be respected." Bach, "The Politics of West African Economic Co-operation," 612.

${ }^{60}$ Olukoshi, "West Africa's Political Economy in the Next Millennium," 7.

${ }^{61}$ See Gowon, "The Economic Community of West African States: A Study in Political and Economic Integration,". 212.

${ }^{62}$ See Brian Z. Tamanaha, "The Primacy of Society and the Failures of Law and Development" (2011) 44 Cornell International Law Journal 209-44, 214. Further, Tamanaha states that "What I have coined the
} 
Another aspect of the political matrix prior to the creation of ECOWAS that adds a different layer of complexity to the implementation of the treaty was the role of Nigeria as a powerful regional member and chief financier of ECOWAS. ${ }^{63}$ Through the creation of ECOWAS therefore, Nigeria hoped to create a market for its growing industries, neutralize its regional opponents, and also reduce French influence in the region. ${ }^{64}$ ECOWAS "helped Nigeria to consolidate its status as regional hegemon by indicating to neighbouring countries that they would benefit from Nigeria's oil wealth and from access to its large and lucrative market." ${ }^{65}$ The risk here is that the regional trade agreement reinforces the existing inequality among the Community members. As Clair Gammage observes, "from a social conflict perspective, [regional trade agreement] privileges the dominant [country]." ${ }^{66}$ Nigeria's agenda as a regional hegemon, however, triggered further estrangement in the Community that destabilized the potential for the regional trade agreement to enhance the economic commitment of the members.

'connected of law' principle is the legal angle on what is ultimately the connectedness of society-the entirety of which includes culture, politics, economics, law, and everything else."

${ }^{63}$ See Olatunde J. B. Ojo, "Nigeria and the Formation of ECOWAS" (1980) 34:4 International Organization, 571-04.

${ }^{64}$ According to Bach,

[a]lthough Nigeria had originally expected that the creation of E.C.O.W.A.S. would weaken francophone West Africa's links with France, this attitude was not really derived from any conviction that the reduction of trade links with Europe and the intensification of inter-African trade were preconditions for the success of economic integration in the region. Nigeria was particularly critical of the relations of direct dependency, which existed, between France and most francophone West African states within the franc zone. But, even if Britain had looser relations with Nigeria and other ex-colonies, the economic policies of the Federal Government showed no signs of being designed to challenge the links which it maintained with the West." "The Politics of West African Economic Co-operation," 610.

${ }^{65}$ See, Alter et al., "A New International Human Rights Court for West Africa: The ECOWAS Community Court of Justice," 742.

${ }_{66}$ Gammage, "(Re)conceptualising International Economic Law: A Socio-Legal Approach to Regionalism," 69. 
The second dimension of the political contexts on the implementation conundrum in ECOWAS relates to the concerns of the Member States. After the adoption of the ECOWAS Establishing Treaty, the prioritization of national economic and political objectives, coupled with the protection of national sovereignty by Member States were important factors in the implementation of the treaty. Assessing the growth in bureaucracy and institutions within ECOWAS, Bach argues that the "limited cooperation actually achieved has been based on strengthening links which were developed in the region since the early $1960[\mathrm{~s}]$ rather than on the transfer of state prerogatives to Community organs on specific issues." ${ }^{67}$ The skepticism of creating institutions with jurisdiction over the Member States is rooted in the historical process of African state formation and the fear of being undermined by integration as a result of loss of control of borders. ${ }^{68}$ According to Emmanuel Fanta,

[f]or African states, the struggle against ('neo-')colonialism was also a struggle to gain their national sovereignty and free the state from external jurisdiction. As a result, African states have resisted political processes that could impede their national sovereignty. And as such, regional integration has been perceived as a process that hinders their hard-gained sovereignty....For both historical reasons and more practical and economic reasons, in Africa there is a strong reluctance to transfer sovereign powers to other levels of governance than the state.

The lack of political will often cited by scholars as the rationale for non-implementation of ECOWAS treaties indeed is a reflection of the reluctance of ECOWAS Member States to cede their hard-earned sovereignty. ECOWAS, it was anticipated, would consolidate and strengthen their national sovereignty as opposed to requiring them to cede political authority to it. In reality, therefore, "the 1975 ECOWAS Treaty created a system of

\footnotetext{
${ }^{67}$ Bach, "The Politics of West African Economic Cooperation", at 605.

${ }^{68}$ Emmanuel Fanta, "Understanding Regional Integration Politics in Africa," in Comparative Regionalisms for Development in the 21st Century, ed. E. Fanta, T. Shaw, and V. Tang (Farnham: Ashgate, 2013), 41-56, $46-47$.
} 
policymaking bodies that governments tightly controlled." ${ }^{29}$ This was a further dimension to the fact that the ECOWS Establishing Treaty was embedded in the social relations and social structure of the ECOWAS Member States, and its implementation was regulated in the shadow of this context.

The final example that reinforces the re-conceptualization of ECOWAS as a social phenomenon as a way to illuminating the implementation conundrum relates to the dispute settlement mechanism under the establishing treaty. The treaty provided for the establishment of a tribunal that would entertain disputes arising from the Community laws. During the lifespan of the ECOWAS Establishing Treaty, no tribunal was established. Alter et al. proffer two reasons for the inactivity of the tribunal, namely Nigeria's regional hegemony and weak legal underpinnings of the Community court; ${ }^{70}$ however, the trend was also reflective of the broader nature of the social relations between the Member States. In particular, despite the raucous nature of their sociopolitical and economic relations or contravention of community laws, the Member States will not resort to adversarial means of settlement of settling disputes. An interesting dimension to the treaty was that it encouraged ECOWAS Member States to seek amicable resolution of their disputes. While I have not uncovered any evidence to the effect that an out-of-court settlement was indeed undertaken, the question is how do we construe this semi-adversarial nature of the dispute settlement provision in the ECOWAS Establishing Treaty and the subsequent inaction in setting up the tribunal?

\footnotetext{
${ }^{69}$ Karen J. Alter et al. "A New International Human Rights Court for West Africa," 737-779, 741.

${ }^{70} \mathrm{Ibid}, 745-746$.
} 
I contend that the broader context of the political and social interconnection of the members provide the answer. Adversarial dispute settlement does not mesh with the socio-political relations of ECOWAS Member States. If the drafters of the ECOWAS Treaty wanted a strong judicial institution, the EEC that served as a model already had a functional court system that could have been adopted. The common thread in the foregoing, therefore, is that the formal provisions of the treaty that should regulate the economic relations of the Community are indeed subject to the social relations of the members. A contradiction that emerges from the foregoing relates to the idea that ECOWAS Member States were careful not to litigate disputes between them in an adversarial context because it avoids taking actions that threaten their regional unity in the face of hegemony in their relations with former colonial powers. Conversely, such inaction also avoids jeopardizing their new-found sovereignty.

In sum, the above analysis identifies some of the key objectives of the ECOWAS Establishing Treaty and discusses the complex economic and socio-political contexts that shaped their implementation. The implication is that given the multifaceted objectives of ECOWAS, and the complex social relations as well as prevalent social and political conflicts that underpin the economic relations among Member States, they explicate the limitation of speaking categorically of the regime in strict success or failure terms. In the next section, I deepen this analysis by examining the ECOWAS Trade Liberalization Scheme as an important site of interaction for law, economy, and social interaction in ECOWAS. The analysis also explicates the peculiar trajectory that ECOWAS Establishing Treaty was situated in the 1980s with the introduction of neoliberalism. 


\subsection{The New International Economic Order}

The New International Economic Order episode was short, but its legacies provide an important episode in the socio-political and ideological contexts of the 1980s, and hence for the explication of the implementation conundrum of the ECOWAS Establishing Treaty. Perhaps the most significant event of the 1970s was the adoption of the NIEO proposals by developing countries at the United Nations General Assembly. ${ }^{71}$ At the core of the NIEO proposals were a series of interconnected goals that called for the reform of the structure, governance, and norms of the international economy with the aim of improving the relative position of the Third World countries. The NIEO "was not a single coherent entity; rather, it was more like a political brand holding together a set of loosely compatible agendas." 72 Despite this incoherence, it is possible to distinguish three interconnected aspects of the project: "economic proposals, legal tactics, and political objectives." $^{, 73}$

The NIEO was a project with significant ramifications, particularly in the West African regional contexts, for two reasons: it was adopted a year before the establishment of ECOWAS and its substantive aspirations were to be implemented by regional economic cooperation at different levels. The NIEO was especially crucial for many African

\footnotetext{
${ }^{71}$ See United Nations General Assembly, Declaration on the Establishment of a New International Economic Order, Resolution 3201 (S-VI), 1 May 1974, http://www.un-documents.net/s6r3201.htm; United Nations General Assembly, Programme of Action on the Establishment of a New International Economic Order, Resolution 3202 (S-VI), http://investmentpolicyhub.unctad.org/Download/TreatyFile/2775.

${ }^{72}$ Gilman, "The New International Economic Order: A Reintroduction," 2. According to Nils Gilman, "the NIEO Declaration called for: (a) an absolute right of states to control the extraction and marketing of their domestic natural resources; (b) the establishment and recognition of state- managed resource cartels to stabilize (and raise) commodity prices; (c) the regulation of transnational corporations; (d) no-stringsattached technology transfers from north to south; (e) the granting of preferential (nonreciprocal) trade preferences to countries in the south; and (f) the forgiveness of certain debts that states in the south owed to the north. Together, all these proposals amounted to an assertion of the "economic sovereignty' of postcolonial states." Gilman, "The New International Economic Order: A Reintroduction,” 3.

${ }^{73}$ Ibid.
} 
countries because of the potential promise of national economic sovereignty based on a restructuring of the international economic order that was stacked against their interests. The political manifesto of the NIEO envisaged a revolutionary order of global economic cooperation in which developing countries in the Global South could catch up with the economic achievements of the developed North, thus creating a material foundation for political equality between states in the North and South. ${ }^{74}$ In addition, such platform would offer many of the developing countries the opportunity to make decisions about their future where they did not have such an opportunity during their years under colonialism. $^{75}$

As exporter of raw materials, producing post-colonial African states "found themselves in an increasingly competitive, industrializing world, with rising tariff barriers, quotas and other restraints on trade, with unpredictable shifts in the commodity markets, higher prices for imported goods and greatly diminished returns for their own [primary] produce." ${ }^{, 76}$ The challenge for African international jurists like Mohammed Bedjaoui was how to assert the absolute national sovereignty of southern states without at the same time empowering northern states to ignore, in the name of their own national sovereignty, the supranational legal injunctions proposed by the NIEO. This tension within the legal doctrine of the NIEO mirrored the one in the economic sphere: claims of absolute economic sovereignty flew in the face of transnational economic interdependence. At the end of the day, NIEO success

\footnotetext{
74 Ibid. Tanzanian president Julius Nyerere called "'a trade union of the poor.' See, Julius K. Nyerere, "Unity for a New Order," Arusha, Tanzania, February 12, 1979.

${ }^{75}$ Mohammed Bedjaoui, an Algerian jurist, provided the most elaborate legal theoretical articulation of how the NIEO's economic aspirations were to be achieved.. Mohammed Bedjaoui, Towards a New International Economic Order, (Holmes \& Meier Publishers, 1979); also see, "'In the interests of mankind as a whole': Mohammed Bedjaoui's New International Economic Order" 6 (2015) Humanity: An International Journal of Human Rights, Humanitarianism, and Development129-43.

${ }^{76}$ Gowon, "The Economic Community of West African States: A Study in Political and Economic Integration", supra note 4, p. 101-102
} 
required levelling power disparities between states, but for that to happen, its legal strategy had to be embedded in a political strategy. ${ }^{77}$

Kwame Nkrumah, for example, considered the politics of the NIEO as a framework for "achieving a more harmonious and mutually beneficial model of global economic and political integration."78 The NIEO drew wide support across the continent of Africa. Affirming Africa's commitment, Alhaji Shehu Shagari, the president of Nigeria from 1979 to 1983 argues that "it is only through regional and continental economic planning and cooperation that [Africa] can attain...economic independence within the framework of the New International Economic Order." ${ }^{79}$ Similarly, Julius Nyerere stressed that regional "economic co-operation among African states is an essential part of the struggle to maintain their freedom and without it, Africa will remain subordinated to "the economies - and thus in the power — of the Big States." ${ }^{80}$ Specifically, the NIEO Program of Action provides that

[c]ollective self-reliance and growing co-operation among developing countries will further strengthen their role in the new international economic order. Developing countries, with a view to expanding co-operation at the regional, sub-regional and interregional levels should take further steps, inter alia...to promote, establish or strengthen economic integration at the regional and sub-regional levels. ${ }^{81}$

Regional economic cooperation schemes such as ECOWAS were viewed as important mechanisms for the implementation of the NIEO objectives. According to Yakubu Gowon, West African leaders were reassured that ECOWAS will generate "a new

\footnotetext{
${ }^{77}$ Gilman, "The New International Economic Order: A Reintroduction,” 5.

${ }^{78}$ Ibid., 6

${ }^{79}$ S. Shagari, "Messages from Heads of State or Government" in Regionalism and the New International Economic Order, ed. D. Nicol, L. Echeverria, and A. Peccei (Oxford: Pergamon Press, 1981), 379-80, 380.

80 J. K. Nyerere, "Non-Alignment in the 1970's," Julius Nyerere, Speeches and Statements, http://got.go.tz/egov uploads/documents/non alignment in the 1970s sw.pdf

${ }^{81}$ Article VII(1)(c) of the NIEO Program of Action.
} 
political and economic order in the region that would one day usher in an era of political, social and economic justice." ${ }^{82}$ Similarly, for S. K. B. Asante, ECOWAS was "an integral part of a wider desire of the states of the sub-region to eliminate, or at least reduce, the inequalities inherent in the...international economic system." ${ }^{83}$

Unfortunately, as early as 1976 - a year after the adoption of the ECOWAS Establishing Treaty - it was clear that ECOWAS was inadequately positioned to challenge the unequal international economic order and a mechanism for restructuring the dependency of its Member States. A leading West African economist, Adebayo Adedeji, who was involved in the drafting of the ECOWAS Establishing Treaty, observed that of the eight principal aims of ECOWAS, "none provides for bargaining between the ECOWAS countries and the rest of the world, particularly, the industrialized part of it. I must admit, with the wisdom of hindsight, that this is a regrettable omission." ${ }^{.84}$ By 1980, the optimism of the promise of the NIEO had fizzled as the Bretton Woods Institutions started spreading the message of neoliberalism. ${ }^{85}$ I now turn to the analysis of the ECOWAS Trade Liberalization program and the Structural Adjustment Policies (SAP) of the Bretton Woods Institutions that provided the conduit through which international organizations-

\footnotetext{
${ }^{82}$ See generally Gowon, "The Economic Community of West African States," iii.

${ }^{83}$ S. K. B. Asante, The Political Economy of Regionalism in Africa: A Decade of the Economic Community of West African States (ECOWAS) (New York: Praeger Special Studies1986), 2-3.

${ }^{84}$ See Adebayo Adedeji, "Collective Self-Reliance in Developing Africa: Scope, Prospects and Problems," Keynote Address at the International Conference on the Economic Community of West African States, Lagos, 23-27 August 1976, 9, http://repository.uneca.org/bitstream/handle/10855/21823/Bib69587.pdf?sequence $=1$ (Last visited 20 January 2015).

${ }^{85}$ See Umut Ozsu, "Neoliberalism and the New International Economic Order: A History of 'Contemporary Legal Thought,"' in In Search of Contemporary Legal Thought, ed. Christopher L. Tomlins and Justin Desautels-Stein (Cambridge: Cambridge University Press, 2016); "Rendering Sovereignty Permanent? The Multiple Legacies of the New International Economic Order" (2017) European Yearbook of International Economic Law (forthcoming).
} 
the World Bank and the International Monetary Fund in particular-promoted neoliberal ideologies in Africa.

\subsection{Situating the ECOWAS Trade Liberalization Scheme (ETLS) in the Socio- Political Contexts of the 1980 to mid-1990 West Africa}

The period starting from 1980 was laden with economic turmoil and political conflicts in the West African sub-region and important ideological changes at the international level. ${ }^{86}$ These precarious events after 1980 provided the context for the emergence and implementation of the ECOWAS Trade Liberalization Scheme (ETLS). It is important to note that the aim in this section is not to examine the best practices for achieving trade liberalization; other studies have undertaken that exercise. ${ }^{87}$ Rather, the point is that apart from the non-complementarity of trade that is a condition for effective regional economic integration, I locate the implementation conundrum in relation to the ETLS in three socio-economic and political events: the introduction of neoliberalism, the structural adjustment programs, and the conflicts within the ECOWAS sub-region.

The ETLS is the main ECOWAS operational tool for promoting Free Trade Area. ${ }^{88}$ According to Article 3 of the ECOWAS Establishing Treaty, the establishment of a common market will be achieved through "the liberalization of trade by the abolition, among Member States, of customs duties levied on imports and exports, and the abolition

\footnotetext{
${ }^{86}$ Karen J. Alter et al. "A New International Human Rights Court for West Africa,” 737-79, 743.

${ }^{87}$ Yinka Omorogbe, "The Legal Framework for Economic Integration in the ECOWAS Region: An Analysis of the Trade Liberalisation Scheme," (1993) 5 African Journal of International and Comparative Law, 355; also see Gathii, "The Status of African Regional Trade Agreements," 288-351.

${ }^{88}$ On ECOWAS Trade liberalization scheme, see generally http://www.etls.ecowas.int.
} 
among Member States, of non-tariff barriers. ${ }^{" 89}$ The ETLS reflects the wider ECOWAS market integration plan that is aimed at creating a common market to ensure the free flow of regionally traded goods and services, free movement of labor and capital within the ECOWAS community. It is designed to create opportunities by opening new markets for goods and services; increasing investment opportunities; making trade cheaper through the elimination of all customs duties; and making trade faster by facilitating goods transit through customs and setting common rules on technical and sanitary standards. By eliminating all tariff and non-tariff barriers that restrict intra-ECOWAS trade, the Member States hoped for the establishment of a common external tariff and commercial policy against non-ECOWAS countries. ${ }^{90}$ Despite the adoption of the ETLS protocol in 1979, concrete steps towards the implementation of the ETLS would not be taken until $1990 .{ }^{91}$ If successfully implemented, the ETLS program would encourage regional supply chain integration and reduce consumer prices on goods and services that are produced within the region. ECOWAS Member States have not complied with ETLS. ${ }^{92}$ It nevertheless declared itself a free trade area in 2000 and a Customs Union transformation date was set for 1 January 2001.

\footnotetext{
${ }^{89}$ Ibid.

${ }^{90}$ See ECOWAS Vanguard Press Release, "The ECOWAS Trade Liberalisation Scheme: Genesis, Conditions and Appraisal," January 2013, 2:3, http://www.nants.org/wpcontent/uploads/2015/02/The ECOWAS Trade Liberalization Scheme Genesis Conditions and Apprai sal ECO VANGUARD Jan 2013 English Edition .pdf.

${ }^{91}$ See ECOWAS Vanguard Press Release, "The Current Status, Challenges and Benefits of Implementing the ECOWAS Trade liberalization Scheme," 4 April 2015, 3:2, http://www.nants.org/the-current-statuschallenges-and-benefits-of-implementing-the-ecowas-trade-liberalisation-scheme/.

92 Marian Efe Ansah, "Nigeria Not Complying with ECOWAS Trade Liberalization Scheme," Monday 7 April 2015, http://citifmonline.com/2014/04/07/nigeria-not-complying-with-ecowas-trade-liberalizationscheme-mahama/.
} 
Critics of this program, like S. K. B. Asante, have rightly noted that "there is little purpose in liberalizing trade when the parties have nothing to exchange: regional cooperation, inter alia must create the basis for trade." ${ }^{93}$ Asante argues that the "unwillingness of African governments to subordinate immediate national political interests in order to achieve long-term regional economic goals...or to cede essential elements of sovereignty to regional institutions" as well as the "absence of monitoring and enforcement mechanisms to ensure adherence to agreed time-tables on such matters as tariff and NTB (non-tariff barrier) reductions" are factors that detracted from the achievement of the trade liberalization goals. ${ }^{94}$ Beyond the lack of comparative advantage among ECOWAS Member States, another reason that has been suggested for the lacklustre advance of trade liberalization within ECOWAS is the lack of infrastructure that would support effective trading among the Member States. Yet, there were other socio-political and economic contexts at the international, regional, and national levels that influenced the implementation of the trade liberalization in ECOWAS and have not been incorporated in the analysis. ECOWAS and the ETLS were not isolated from the rest of the world. Instead their trajectory was significantly shaped and affected by changing economic and political international contexts, and not simply by the black-letter law of the ECOWAS Establishing Treaty.

Among the important events that shaped the implementation of ECOWAS in the 19802000 decades was the turn to neoliberalism as a new economic development ideology, Structural Adjustment Programs (SAPs), and their associated stabilization policies in

\footnotetext{
${ }^{93}$ Asante, "The Strategy of Regional Integration in Africa," 25.

${ }^{94}$ Mistry, "Africa's Record of Regional Co-operation and Integration," 553-73, 558.
} 
Africa by the World Bank and the International Monetary Fund. ${ }^{95}$ According to James Mittleman,

"[n] eoliberal theory has been put into practice in the form of adjustment drawn up by the World Bank and the International Monetary Fund (IMF). The main beneficiaries of such neoliberal projects are internationally mobile capital, exporters who balk at restrictive trade policies, [and] and local industrialists and domestic financial capital positioned to gain from liberalization and increased access to foreign markets. Not covered by the neoliberal umbrella are the interests of other social forces, which must seek an alternative venue." 96

SAPs emphasized outward looking policies that pose important questions for regional integration among developing countries. ${ }^{97}$

Although the trade liberalization scheme would appear to follow organically from the adoption of the ECOWAS Establishing Treaty, trade liberalization and privatization were also part of the policy proposals of neoliberalism. In this regard, it should not be assumed that approaches, whether in the context of regionalism or theories of economic development, advanced by developed countries and diffused by the Bretton Woods Institutions necessarily foster benefits for developing countries. SAPs spread across Africa in a period estimated to be between 1980 and 1999 when its policies heavily influenced the economic development trajectory of these countries as they were required to repay their debts through restructuring their economies away from domestic consumption towards external trade. ${ }^{98}$ The SAPs package was conceptualized to address

\footnotetext{
${ }^{95}$ See K. Meagher, “A Back Door to Globalization: Structural Adjustment, Globalization and Trans-border Trade in West Africa" (2003) 30:95 Review of African Political Economy, 57-75.

${ }^{96}$ James Mittleman, 206.

${ }^{97}$ Peter Robson, "The New Regionalism and Developing Countries" (1993) 31:3 Journal of Common Market Studies, 329-48.

${ }^{98}$ Alter et al., "A New International Human Rights Court for West Africa: The ECOWAS Community Court of Justice," 743: "The end of the Cold War had a significant impact on the Community. West African countries began to liberalize their economies as a condition of receiving loans from the World Bank,
} 
problems of weak management of the public sector, unreliable infrastructure, and investment choices in African countries. ${ }^{99}$ According to Franz Heidhues and Gideon Obare, "the main elements of the SAPs were their classical/neoliberal features. They emphasized anti-inflationary macroeconomic stabilization policies and pushed for private sector and free market development, controlling budget deficits, privatizing public sector companies and services, dissolving parastatals, eliminating subsidies and cutting public support for social services."

SAP, its neoliberal policies, and its later chastised form-" "post-Washington Consensus"- have implications for the operation of regional economic communities in Africa generally and ECOWAS ETLS program in particular. The connection exists at two levels. First, there was a clash at the level of economic development ideas. In particular, the ECOWAS Establishing Treaty was designed and adopted under a developmental state that advocated protectionism and import substitution industrialization with the state as its primary actor would now be implemented in a different era. ${ }^{101}$ Neoliberalism, with its emphasis on open markets, deepening integration into the global economy, and trade liberalization therefore ran into tension with the spirit

gaining access to European markets and, eventually joining the World Trade Organization. These powerful external forces made the embrace of regional economic integration newly attractive."

Also see Franz Heidhues and Gideon Obare, "Lessons from Structural Adjustment Programmes and their Effects in Africa" (2011) 50:1 Quarterly Journal of International Agriculture, 55-64, 57; T. Mkandawire and C. C. Soludo, Our Continent, Our Future: African Perspectives on Structural Adjustment, 1999, CODESRIA (Council for the Development of Social Science Research In Africa).

${ }^{99}$ Franz Heidhues and Gideon Obare, "Lessons from Structural Adjustment Programmes and their Effects in Africa" 58.

${ }^{100}$ Ibid.

${ }^{101}$ Also, Mistry notes that "programmes of debt crisis triggered structural adjustment programmes (SAPS) whose conditionalities did not take account of regional costs and benefits....[They] proved to be less effective and timely (in terms of results and outcomes) than they might have been if regional rather than national perspectives in the design of SAPs had been adopted in the first place." Mistry, 559. 
of the ECOWAS Establishing Treaty. ${ }^{102}$ Second, at the national level, as SAP and its neoliberal policies gained traction, governments of ECOWAS Member States were constrained to realign their economic policies in line with the conditionalities of the International Monetary Fund. The negative implications of these policies on many African countries have been adequately documented. ${ }^{103}$ But the primary implication for the practice of regionalism was that it entrenched the prioritization of national objectives over regional goals. For example, Nigeria was virtually unilaterally responsible for the funding of ECOWAS formation because of its oil revenue income from the boom in the 1970s. Where Nigeria's economic stability as the major ECOWAS financier had been initially impacted by "the collapse of world oil prices and the mismanagement of oil revenues...[which] led Nigeria to focus on domestic priorities and deemphasize its commitment to ECOWAS," the deregulation of its economy through privatization and other neoliberal policies compounded the economic woes of the country. ${ }^{104}$

By the 1980s, the support and optimism from Nigeria was waning, and this meant that the country was unable to shoulder as much of the financial burden as it had intended coming into the next decade. For S. K. B. Asante, "the regime of structural adjustment programmes which has prevailed in most of West Africa (as indeed in the rest of Africa) for most of the existence of ECOWAS has hindered the integration process

\footnotetext{
${ }^{102}$ Ibid., 59.

${ }^{103}$ William Easterly, "What Did Structural Adjustment Adjust? The Association of Policies and Growth with Repeated IMF and World Bank Adjustment Loans" (2005) 76 Journal of Development Economics, 122; David Dollar and Jakob Svensson, "What Explains the Success or Failure of Structural Adjustment Programmes?" (2000) 110 Economic Journal, 894-917; J. Barry Riddell, "Things Fall Apart Again: Structural Adjustment Programmes in Sub-Saharan Africa" (1992) 30:1 Journal of Modern African Studies, 53-68.

${ }^{104}$ Alter et al., "A New International Human Rights Court for West Africa: The ECOWAS Community Court of Justice," 737-79, 743.
} 
tremendously." ${ }^{105}$ These events also coincided with political changes in Nigeria as military government once again returned to power.

The effect was that regional economic policies were neglected as national economies struggled. The economic woes in the national economies of the ECOWAS Member States exacerbated the existing strain and division in the social relations of the Community Members. In this regard, some critics of SAP and neoliberalism have noted the insufficient attention paid to the social aspects of development in African countries as an important factor that further derailed the ETLS. ${ }^{106}$ The rise of private parties in the economic relations of Member States altered their economic relations. For investors, the primary concern was to recuperate their investment and not promote regional cooperation. In other words, their emergence as effective economic actors deepened trading with the international economy and further opened the region and the continent to the international economic forces they sort to restructure but failed in the 1970s through the NIEO.

SAP and neoliberalism, as Kofi Oteng Kufuor notes, also heightened the socio-political relations and conflict among Community members as the question of who would benefit from the scheme rejuvenated the rivalry and fear by some anglophone Member States (Nigeria and Ghana) that the French firms in Senegal and Côte d'Ivoire would benefit

\footnotetext{
${ }^{105}$ S.K.B. Asante, "Report on an Advisory Mission on Review of the ECOWAS Treaty," 8-9.

${ }^{106}$ Ibid.; also see Trubek and Santos, eds., The New Law and Economic Development; P. Carmody, "Constructing Alternatives to Structural Adjustment in Africa," (1998) Review of African Political Economy, 25-46.
} 
more. ${ }^{107}$ It was against such a premise that G. A. Obiozor, A. O. Olukoshi, and C. I. Obi opined that "the deep-seated economic problems confronting all the countries of the subregion have generated or exacerbated social and political problems in West Africa to the point where serious problems of state survival and security have arisen."

With most ECOWAS Member States' national economies facing a severe downturn by the beginning of the 1980s, the ETLS was significantly divorced from the realities of its members who have had to adopt neoliberal policies prescribed by Bretton Woods Institutions. Given the social and political divergences between their conditions and the policy prescriptions of the ETLS - which mirrors one of the elements of the structural adjustment program-ECOWAS Community members honoured their commitments more in breach as national interests were accorded priority above regional cooperation.

From the foregoing, simultaneous economic and political events at the international and national levels shaped the implementation of ECOWAS Establishing Treaty. ECOWAS was both a regional framework to consolidate "political sovereignty" of West African states principally through cooperation and a platform to challenge the imbalance in the international economic order in search of "economic sovereignty." 109 The changes occasioned by SAPs, neoliberalism, and the deepening economic crises had a distorting

${ }^{107}$ Kufour, The Institutional Transformation of the Economic Community of West African States, 26-28.

${ }^{108}$ G. A. Obiozor, A. O. Olukoshi, and C. I. Obi, eds., West African Regional Economic Integration: Nigerian Policy Perspectives for the 1990s, (Uppsala: Nordiska Afrikainstitutet, 1999), ix.

${ }^{109}$ See Aboubakar Diaby-Ouattara, "A New Look at the Process of Economic Integration: An Address" in Trade \& Development in Economic Community of West African States, ed. Adeyinka Orimalade and R. E. Ubogu (New Delhi: Vikas Publishing House PVT, , 1984), 19-22. Argues that the rationale behind the formation of ECOWAS is predicated on three important public policy goals: i) to ensure success in the struggle against domination and subjugation by external forces; ii) alleviation and eventual elimination of poverty in the region; and iii) consolidation of national economic development to overcome the limitations of the individual countries. Diaby-Ouattara, "A New Look at the Process of Economic Integration," 19. 
impact on the implementation of the ETLS and the ECOWAS Establishing Treaty, but so did the fact that the treaty was underpinned by the opposing ideology of developmental state. The challenges with the implementation of the treaty were deeply embedded in the social relations and conflicts of the region. Reading ECOWAS broadly in terms of the interconnectedness of the political, social, and political helps explicate some of the conflicts between the traditional trade enhancing perspectives of such schemes and the unique implementation trajectory of ECOWAS. In the next section, with the benefit of hindsight, I examine the implications of this socio-legal analysis for the implementation of ECOWAS.

\subsection{Conclusion}

Debates about the non-implementation of the textual goals of the ECOWAS Establishing Treaty have been part of the mainstream analysis of what some critics see as the failure of ECOWAS. Too often, the failure narrative obscures other important aspects that come to light if ECOWAS is conceived as a social phenomenon. The chapter identified a series of historical, economic, and political factors that influenced the implementation and the relationship of ECOWAS Member States. By revisiting the analysis and injecting the complex social conflicts and socio-political relations, the chapter demonstrated that the fluidity of economic, social, historical, and political events in West Africa following the establishment of ECOWAS and broader ideological changes in the international economic order at large with impact on African countries belies such a definitive approach. 
From this perspective, ECOWAS Establishing Treaty was immersed in a complex sociopolitical and unequal structure in West Africa. Reflecting on the ECOWAS establishing regime, Morten Bøås notes that "it seems as if the poverty of ECOWAS members, the undiversified structure of their economies, the economic, cultural, political, and ideological differences between them as well as the political instability of many member countries have entailed that ECOWAS remains a 'dead letter office' in international politics." 110

The implementation of the ECOWAS Establishing Treaty diverged from the strict legal formalism or positivism that is associated with Eurocentric reading of similar treaties in the EU. In this regard, other than the economic shortcomings of the trade agreement, it fulfilled social and political function among the Community members. Some of the core principles that were important to ECOWAS members include but are not limited to mutual respect for Member States' independence, sovereignty and territorial integrity; non-interference in the local or international affairs of one another; resolution of differences or disputes by peaceful or non-adversarial means and multipurpose cooperation among Member States. These principles shaped the implementation of the treaty. In addition, the fragile political circumstances of many ECOWAS Member States were often recipes for military coups, and the relatively poor economic condition of most states, the introduction of neoliberalism, and the continued dependence on former colonial power shaped the implementation of ECOWAS.

\footnotetext{
${ }^{110}$ See Morten Bøås, "Regions and Regionalisation: A Heretic's View" in Regionalism and Regional Integration in Africa: A Debate of Current Aspects and Issues (Sweden: Nordiska Afrikainstitutet, Uppsala, 2001), 27-39, 31 .
} 
Properly contextualized, notwithstanding the challenges regarding non-implementation and critique of effectiveness or failure of the trade related aspects of ECOWAS, the era of the ECOWAS Establishing Treaty emerges as a crucial point for building the foundations for a future economic community. It also solidified the sovereignty of the Member States at a time when their independence was still a novel political experience. Finally, viewed against the background of colonialism and the oppressive socio-political relations between the former colonies and the European colonial states, ECOWAS would be a mechanism to reduce external dependency of ECOWAS Member States in order to overcome existing oppressive structures of the international economic order of the 1970s, neo-colonialism, and underdevelopment. Seen in this light, any judgment that considers ECOWAS as a straightforward failure requires modification. 


\section{Chapter 5}

\section{Revisiting the Economic Community of West African States Treaty of 1993}

Although existing scholarship have been critical of the implementation of the Revised ECOWAS Treaty, sufficient attention has not been paid to the context of the social, political, economic, and ideological changes that have influenced its implementation to date. ${ }^{1}$ At the international level, the promotion of good governance, rule of law, human rights protection, and democratization by international institutions provided important contexts for the implementation of the Revised ECOWAS Treaty. At the regional level, social conflicts, changes from military dictatorship to democracy, and the conduct of multiparty elections, as well as power dynamics all create important contexts that may go unaccounted for if the analysis is limited to just trade liberalization or economic integration. To the extent that this evolving and complex triad of socio-political and economic factors influenced the revisions and continues to shape the implementation of the treaty, it reinforces the argument that simply interpreting the treaty provisions as gapless and conclusive is insufficient for understanding ECOWAS. The chapter begins with an analysis of the treaty and the ECOWAS Parliament, and after this, I explicate the impact of globalization, good governance efforts, rule of law, democratization, regional socio-political conflicts and instability, and power dynamics among Community members on the implementation of ECOWAS.

\footnotetext{
${ }^{1}$ See Revised ECOWAS Treaty, http://www.ecowas.int/wp-content/uploads/2015/01/Revised-treaty.pdf.
} 


\subsection{Background: Socio-Political Context of the Revision of the ECOWAS Treaty}

Prior to the analysis of the Revised ECOWAS Treaty, this section examines the complex set of exogenous and endogenous factors that influenced the revision of the treaty. ${ }^{2}$ In examining these complex factors that sometimes occur simultaneously, the claim is that the revision is not simply a consequence of the failure of the ECOWAS Establishing Treaty, rather, it is also a consequence of socio-political and economic changes of the global orders. While the effects of these factors continue to shape the implementation of the Revised ECOWAS Treaty, I turn to that analysis only after the review of the treaty.

By the early 1990s, it was clear that the developmental state, protectionism, and import substitution industrialization that underpinned the establishing treaty were out of step with the new order of neoliberalism. ${ }^{3}$ Internationally, neoliberalism, globalization, and the good governance agenda provided a broad umbrella through which international institutions in the Global North diffused socio-political and economic ideas to the Global South. Although the programs were introduced in the national economies, once

\footnotetext{
${ }^{2}$ See generally Mamadou Alpha Diallo, "Regional Integration in West Africa (1960-2015): Balance and Perspectives" (2016) 1:1 Brazilian Journal of African Studies, 234-54. "The colonial legacy continues, as we can see, to be one of the main obstacles to state's formation and the regional integration of the African continent's processes. When we analyze the endogenous and exogenous factors of West African Integration, we realize that both emanate from the same source. That is, both endogenous as exogenous barriers are the result of the colonial legacy, which gained more sophistication and deepening with the political elites who administered and managed African states after independence." Diallo, "Regional Integration in West Africa," 242-43.

${ }^{3}$ See Ian Taylor, "Globalization and Regionalization in Africa: Reactions to Attempts at Neo-liberal Regionalism" (2003) 10:2 Review of International Political Economy, 310-30. Terry Flew synthesizes different uses of neoliberalism into six categories arguing that they are not mutually compatible while denouncing the general association of the concept with "any thing and everything that a particular author may find objectionable." (i) Neoliberalism as an all-purpose denunciatory category; (ii) Neoliberalism as "the way things are"; (iii) Neoliberalism as institutional framework characterizing particular forms of national capitalism-mostly Anglo-American ones; (iii) Neoliberalism as a dominant ideology of global capitalism; (iv) Neoliberalism as a form of governmentality and hegemony; and (v) neoliberalism as a variant of within the broad framework of liberalism as both theory and policy discourse. See Terry Flew, "Six Theories of Neoliberalism" (2014) 122:1 Thesis Eleven, 49-71.
} 
entrenched, their influence on economic cooperation in regional organizations such as ECOWAS was undeniable. ${ }^{4}$ The good governance proposals primarily championed by the World Bank promoted different political and economic ideas that were at times contradictory, yet reproduced, and were a continuum of the effect of the structural adjustment programs of the 1980s. Percy Mistry captures the difference in the regional economic cooperation in the 1990s:

the new approach has abandoned the ossified, static, protected-fortress approach to integration among closed, state-run economies. It lays more emphasis on development of thematic integration... and open, rather than protected, market enlargement as a means of consolidating national economic policy shifts towards greater liberalization, market orientation, competitiveness and efficiency. ${ }^{5}$

Similarly alluding to the dominance of the new practice of regionalism in the 1990s, Kate Meagher notes that old regionalism was thoroughly discredited and "has been cast aside, presumably into the same pile as the developmental state, too outmoded and cumbersome to fit in with the globalized, outward-looking decor of the postmodern era." ${ }^{, 6}$ It is not contested that the Revised ECOWAS Treaty is underpinned by neoliberalism. ${ }^{7}$ However, this is only an aspect of the narrative. The other aspect that most scholarship has not paid attention to is the overlap between neoliberalism and developmental state in the 1990s. I

\footnotetext{
${ }^{4}$ Alassane D. Ouattara, "The Challenges of Globalization for Africa" International Monetary Fund, 21 May 1997, https://www.imf.org/en/News/Articles/2015/09/28/04/53/sp052197.

${ }^{5}$ See Mistry, "Africa's Record of Regional Co-operation and Integration" (2000) 99 African Affairs, $553-$ 73, 559-60.

${ }^{6}$ Kate Meagher, "Throwing out the Baby to Keep the Bathwater: Informal Cross-Border Trade and Regional Integration in West Africa" in Regionalism and Regional Integration in Africa: A Debate of Current Aspects and Issues (Sweden: Nordiska Afrikainstitutet, Uppsala, 2001), 40-53, 40. (Arguing that "new regionalist approaches that seek to achieve integration through a further weakening or bypassing of the state and an intensification of liberalization are throwing away the baby to keep the bathwater.")

${ }^{7}$ This has been acknowledged by some jurists, for example see Kofi Oteng Kufuor, The Institutional Transformation of the Economic Community of West African States. He argues that while the design of the ECOWAS Treaty of 1979 was influenced by insights from developmental regionalism, the ECOWAS Treaty of 1993 is informed by the neoliberal agenda. Also see Maxwell O. Chibundu, "NEPAD and the Rebirth of Development Theory and Praxis," in Africa: Mapping New Boundaries in International Law, ed. Jeremy Levitt ( Oxford, UK: Hart Publishers, 2008).
} 
describe the effect of this overlap as a form of hybridity that is at the root of the implementation of the Revised ECOWAS Treaty. I elaborate on this in the next chapter in relation to the ECOWAS Community Court of Justice.

The Revised ECOWAS Treaty was also adopted in the era of globalization. Globalization is however not a one-sided phenomenon; rather, "it manifests in a range of processes and experiences with multiple (often contradictory) consequences." 8 It is "driven not primarily by some inexorable economic process, but rather by politics, by ideology, by the actions, [social] interactions and decisions of state actors, their private-sector interlocutors and wider publics." ${ }^{9}$ The impact of globalization, like neoliberalism, across different regions of the world is not universal. Among African countries, it had varying economic, social, and political consequences across geo-political zones. As Gathii notes, for the "sub-Saharan nation in the global context, the compromise has thus far been presented as a choice between de-linking from an exploitative regime in order to pursue a risky venture of socio-political entrepreneurism or staying put and focusing instead on how the rules of the game can be adapted to make it a better player." ${ }^{10}$ In the West African sub-region, embedded social conflicts and divisions as well as the varying economic conditions of the Member States of ECOWAS further complicate the effect of neoliberalism and globalization in the region.

\footnotetext{
${ }^{8}$ See Robert Lee and Ellen Stokes, "Environmental Governance: Reconnecting the Global and Local" (2009) 36:1 Journal of Law and Society, 1-10, 2.

${ }^{9}$ P. Cerny, "Globalising the Political and Politicising the Global: Concluding Reflections on International Political Economy as a Vocation" (1999) 4:1 New Political Economy, 147-62, 159.

${ }_{10}$ James T. Gathii, "Retelling Good Governance Narratives on Africa's Economic and Political Predicaments: Continuities and Discontinuities in Legal Outcomes between Markets and States" (2000) 45 Vill. L. Rev., 971, 999.
} 
A primary technology of governance of the international institution that was aggressively promoted and linked to the socio-political and economic development of the developing countries of the South was the good governance package. ${ }^{11}$ The package was promoted across Africa during the decade between 1990 and 2000. Good governance, a product of heterogeneous coalition as well as an umbrella term that subsumes a wide range of economic and political themes, was promoted by Bretton Woods Institutions. It is a reconceptualization of orthodox structural adjustment or macroeconomic reform and stabilization. ${ }^{12}$ International donors promoted the good governance discourse as a package with democracy as an important political framework; economic liberalization with less role for the state; active and strengthened civil society; human rights guarantee and protection; and the rule of law as its critical components. ${ }^{13}$ While dissociating itself from the failures of the past development effort, it is positioned as the torchbearer of the future African renaissance, yet "its recommendations amount[ed to] a little more than a new gloss on age-old prescriptions. ${ }^{" 14}$ In many African countries, this move required the transition from military dictatorships to democratic and "semi-democratic" regimes. ${ }^{15}$

\footnotetext{
${ }^{11}$ See generally The World Bank, Governance: The World Bank's Experience (World Bank, 1994); Stephen Brown, "Foreign Aid and Democracy Promotion: Lessons from Africa" (2005) 17:2 European Journal of Development Research, 179-198. Political conditionality "refers to the strings attached to foreign aid, making it dependent on political liberalisation." World Bank, Governance, 194.

${ }^{12}$ Gathii, "Retelling Good Governance Narratives," 1000.

${ }^{13}$ On the role of democracy and accountability in international investment law, see Graham Mayeda, "Investing in Development: The Role of Democracy and Accountability in International Investment Law" (2009) 46:4 Alberta Law Review, 1009-37; J. Anthony VanDuzer, Penelope Simons, and Graham Mayeda, "Modelling International Investment Agreements for Economic Development," in Bilateralism and Development: Emerging Trade Patterns, ed. Veniana Qalo (London: Cameron-May, 2008), 359-410.

${ }^{14}$ Rita Abrahamsen, "The World Bank's Good Governance Agenda, Narratives of Democracy and Power," in Ethnographies of Aid: Exploring Development Texts and Encounters, ed. J. Gould and H. S. Marcussen (The Graduate School, International Development Studies, 2004), 15-44, 39; Rita Abrahamsen, Disciplining Democracy: Development Discourse and Good Governance in Africa, (UK: Zed Books, 2009).

${ }^{15}$ Crawford Young, "The Third Wave of Democratization in Africa: Ambiguities and Contradictions," in State, Conflict, and Democracy in Africa, ed. Richard Joseph (Boulder, CO: Lynne Rienner, 1999), 15-38; also see Richard Joseph, "Democratization in Africa After 1989: Comparative and Theoretical Perspectives" (1997) 29:3 Comparative Politics, 363-82.
} 
The good governance agenda presents its technical and economic proposals as an "ideologically neutral and universal antidote to the 'turmoil,' 'chaos,' corruption, authoritarianism and 'disorder' of the post-colonial African experience." 16

Although reconceptualized, "orthodox structural adjustment remains a primary objective increasing the productive capacities of the private sector as the engine of economic growth, or releasing market forces from the clutches of regulatory controls. Releasing market forces within this framework is premised on the protection and enforcement of the private rights of property and freedom of contract and exchange by using a system of public law." ${ }^{17}$ However, in its implementation, it only reproduced the binaries of the developed and developing that have sustained the discourse in favour of the developed. ${ }^{18}$

With democracy and its institutions, multiparty elections, rule of law, respect of and protection of human rights being gradually entrenched, to various degrees, in the countries that comprise ECOWAS Member States, it was clear that the ECOWAS Establishing Treaty, which was in existence at 1992, was now obsolete. From this point of view, the revision of the ECOWAS Treaty was embedded in the wider development discourse, an "intrinsic part of the technologies of power employed in international politics, and...the way in which it constructs democracy is central to the maintenance of contemporary international relations and structures of power." ${ }^{, 19}$ While the assessment of

\footnotetext{
${ }^{16}$ James T. Gathii, "Representations of Africa in Good Governance Discourse: Policing and Containing Dissidence to Neo-Liberalism" (1998-1999) 18 Third World Legal Stud., 65-108, 67.

${ }^{17}$ Ibid.

${ }^{18}$ Abrahamsen, "The World Bank's Good Governance Agenda, Narratives of Democracy and Power."

${ }^{19}$ Abrahamsen, "The World Bank's Good Governance Agenda, Narratives of Democracy and Power," 16 and 40 .
} 
the effectiveness or success of these proposals in West African countries is beyond the purview of this thesis, together these socio-economic and political changes in ECOWAS Member States sharply contrast the context of the 1970s.

Based on the foregoing background, the question then is, how does the international and regional configuration in the new world order manifest in the ECOWAS context? In the next section, I analyze the ECOWAS Declaration of Political Principles of the Economic Community of West African States as a first step that demonstrates the influence of the promotion of good governance narratives from a regional perspective. Although ECOWAS Member States eventually adopted a Good Governance Protocol, I analyze this as part of the contexts relevant to the implementation of the Revised ECOWAS Treaty and the functioning of the Community Court discussed in the next chapter.

\subsection{The ECOWAS Declaration of Political Principles}

The Declaration, adopted in 1991, encapsulates a set of principles to which the ECOWAS Members would adhere in order to enhance economic cooperation and integration in a political environment of peace, security, and stability. ${ }^{20}$ The Preamble provides that ECOWAS Member States are committed to promoting democracy based on political pluralism and respect for fundamental human rights as universally recognized and enshrined in various international instruments and the African Charter on Human and

\footnotetext{
${ }^{20}$ Declaration A/DCL.1/7/91 of Political Principles of the Economic Community of West African States, adopted at the 14th Session of the Authority of the Heads of State and Government Abuja, 4-6 July 1991. Online http://www.eods.eu/library/ECOWAS Declaration\%20of\%20Political\%20Principles\%20of\%20the \%20Ec onomic\%20Community\%20of\%20West\%20African\%20States 1991 EN.pdf.
} 
Peoples Rights. The Preamble specifically invokes the fact that the ECOWAS Members are

deeply conscious of the rapidly changing international political and economic landscape in favour of a resurgence of economic regionalism which imposes on the Members of ECOWAS a special awareness of the need to intensify and strengthen their own integration efforts and to resist all forms of foreign interference aimed at undermining their solidarity and integration efforts.

The Declaration contains eight key principles and socio-political commitments. Some of the principles include: reaffirmation of their commitment to the Protocol on NonAggression; securing peace and maintaining stability in the region; respect for mutual relations, territorial integrity and political independence; "determination to settle all disputes among [ECOWAS Member States] by peaceful means [and] not to endanger the peace, security and stability" of the Community; ${ }^{21}$ respect for human rights and fundamental freedoms of thought, conscience, association, religion etc.; promote and encourage the full enjoyment of the fundamental human rights as well as political, economic, social, and cultural rights of the ECOWAS peoples; and the inalienable right of individuals to participate in free and democratic processes.

One the one hand, these political principles mirror the political conditionality of the good governance proposals. And on the other hand, they foreshadow many of the revisions introduced in the ECOWAS Treaty as well as the protocols on the ECOWAS Community Court. In particular, it is insightful to note the provision that relates to the settlement of disputes by peaceful means as it encapsulates important socio-political norms that

\footnotetext{
${ }^{21}$ Article 3.
} 
underpin and sustain the social and economic relations of the Member States: the idea that they will not adjudicate disputes in an adversarial manner. This underlying approach also sheds some light on the lack of economic cooperation disputes that are based or arise from economic integration aspirations of the Community.

In summary, the implication of the foregoing analysis is that the revision of the ECOWAS Establishing Treaty is a consequence of wider socio-political and economic context both with and outside the ECOWAS Community. The Establishing Treaty was no longer viable as the platform to lead economic cooperation in ECOWAS into the new millennium. The divergence was so wide that continuing with the establishing framework would have left the region significantly behind in continental and global developments. The revision was thus geared towards aligning ECOWAS with the new global and regional economic and socio-political strictures that had taken root in the national economies of its Member States during the decade between 1980 and $1990 .{ }^{22}$ It shifts the focus away from the anti-colonial framing and context of the formation and implementation of ECOWAS in the first era, even if some of the colonial legacies remain active in the social relations of the Community Members.

Determined, therefore, to reposition ECOWAS, the Authority of the Heads of State and Government of ECOWAS constituted a Committee of Eminent Persons (CEP) with the

\footnotetext{
${ }^{22}$ The ECOWAS Authority noted that the ECOWAS Establishing Treaty was revised primarily to "enable the Community to adjust itself to the dramatic changes that were taking place in West Africa, the African continent and in other parts of the World." See Final Report of the Committee of Eminent Persons for the Review of the ECOWAS Treaty dated 9 June 1992, 1-180, 1. The authority for the establishment of the Committee of Eminent Persons for the Review of the 1975 ECOWAS Treaty is contained in Authority Decision A/DEC/10/5/90 dated 30 May 1990, adopted by the Authority of Heads of State and Government at its Thirteenth Ordinary Session in Banjul.
} 
primary responsibility of reviewing the Establishing Treaty and proposing a revised treaty that reflects an organization capable of dealing with the exigencies of the day-in particular the changed global economic order. ${ }^{23}$ The CEP produced a final report and a draft of Revised ECOWAS Treaty. I now turn to the analysis of the text of the revised treaty as adopted in 1993

\subsection{The Revised ECOWAS Treaty}

The Revised ECOWAS Treaty was adopted in 1993. It reiterates the commitment of the Member States to the promotion of harmonious economic development for effective economic cooperation and integration based on a determined and concerted policy of self-reliance. The Preamble incorporates two new paragraphs that were not in the ECOWAS Establishing Treaty. First, it acknowledges that the "integration of the Member States into a viable regional Community may demand the partial and gradual pooling of national sovereignties to the Community within the context of a collective political will." ${ }^{24}$ Second, that ECOWAS Member States accept

the need to face together the political, economic, and socio-cultural challenges of the present and the future, and to pool together the resources of our peoples while respecting our diversities for the most rapid and optimum expansion of the region's productive capacity. ${ }^{25}$ [Emphasis mine]

The ECOWAS Member States undertake to abide by political principles enshrined in the Declaration on Political Principles. ${ }^{26}$ To address the overlapping existence of regional

\footnotetext{
${ }^{23}$ See Letter dated 9 June 1992, by General Dr. Yakubu Gowon Chairman, the Committee of Eminent Persons to Dr. Abass Bundu, the ECOWAS Executive Secretary. (Copy available on file with me.)

${ }^{24}$ See Preamble to the Revised ECOWAS Treaty.

${ }^{25} \mathrm{Ibid}$.

${ }^{26}$ See generally Article 4(a-k).
} 
economic organizations in West Africa, Article 2(1) provides that ECOWAS "shall ultimately be the sole economic community in the region for the purpose of economic integration." 27 ECOWAS's aims and objectives are to establish an economic union and a common market. Article 3(1), mandates ECOWAS Member States to "promote cooperation and integration, leading to the establishment of an economic union in West Africa in order to raise the living standards of the peoples, and to maintain and enhance economic stability, foster relations among Member States and contribute to the progress and development of the African Continent." 28 The aims and objectives of the Revised ECOWAS Treaty extend to the "promotion of joint ventures by private sector enterprises and other economic operators," 29 as well as the "adoption of measures for the integration of the private sectors." 30

To achieve its economic union objective, the Community shall by stages ensure the harmonization and co-ordination of national policies, the promotion of integration programs, projects, and activities across multisectoral areas such as food, agriculture, industry, trade, money, transport and communications, energy, health, tourism, and legal matters. ${ }^{31}$ The common market would be established through the liberalization of trade, adoption of common external tariff, and removal of obstacles to free movement of

\footnotetext{
${ }^{27}$ See Revised ECOWAS Treaty, http://www.courtecowas.org/site2012/pdf files/revised treaty.pdf; also see Richard Frimpong Oppong, "The African Union, The African Economic Community and Africa's Regional Economic Communities: Untangling a Complex Web" (2010) 18 Afr. J. Int'l \& Comp. L. 92, p. 103

${ }^{28}$ Article 3(1), Revised ECOWAS Treaty.

${ }^{29}$ Article 3(2)(f).

${ }^{30}$ Article 3(2)(g).

${ }^{31}$ Ibid., and Article 3(2)(a-c).
} 
persons, goods, services, and capital. ${ }^{32}$ Although ECOWAS plans to launch its single monetary union by $2020,{ }^{33}$ Member States of ECOWAS were directed to start the implementation of a Common External Tariff in January 2015. ${ }^{34}$

The Revised ECOWAS Treaty made significant changes to the design and powers of the institutions of the Community. ${ }^{35}$ The institutional structure of ECOWAS now consists of the Authority of Heads of State and Government; ${ }^{36}$ the Council of Ministers; ${ }^{37}$ the Community Parliament; ${ }^{38}$ the Economic and Social Council ${ }^{39}$ - in anticipation of the greater involvement of the professionals and interest groups in general; the Community Court of Justice; ${ }^{40}$ the Executive Secretariat-now the Commission; ${ }^{41}$ the Fund for

32 Article 3(2)(d)(i-iii); on ECOWAS Trade Liberalization Scheme, see generally http://www.etls.ecowas.int.

33 See The Citizen, "ECOWAS Single Monetary Union to Launch by 2020" (17 July 2014), http://www.thenigerianvoice.com/news/153069/1/ecowas-single-monetary-union-to-launch-in-2020.html;

also see Gabriel Mougani, "Challenges Towards Regional Financial Integration and Monetary Coordination in the West African Monetary Zone and the East African Community," AFDB Regional Integration Policy Paper, No. 3. July 2014.

${ }^{34}$ ECOWAS, "ECOWAS-CET will be Implemented as of January 1, 2015," ECOWAS News Release of 10 December 2014, http://www.ecowas.int/ecowas-cet-will-be-implemented-as-of-january-2015/: "Once the CET comes on board in January 2015, goods imported into, a Francophone country for example, will not necessarily be cheaper or more expensive than those gaining entrance into another (say an Anglophone) country. The CET is a response to the 2006 decision of regional leaders for growth facilitating brand of common external tax regime."

${ }^{35}$ See Kufuor, The Institutional Transformation of the Economic Community of West African States.

${ }^{36}$ Article 6(1)(a), 7-9.

${ }^{37}$ Article 6(1)(b), 10-13

${ }^{38}$ Article 6(1)(c). For more on ECOWAS Parliament, see http://www.parl.ecowas.int/index.html.

${ }^{39}$ Article 6(1)(d), 14.

${ }^{40}$ Article 6(1)(e), 15. The organizational framework, functioning mechanism, powers, and procedure applicable before it are set out in Protocol A/P1/7/91 of 6 July 1991, Supplementary Protocol A/SP.1/01/05 of 19 January 2005, Supplementary Protocol A/SP.2/06/06 of 14 June 2006, Regulation of 3 June 2002, and Supplementary Regulation C/REG.2/06/06 of 13 June 2006.

The mandate of the Court is to ensure the observance of law and of the principles of equity in the interpretation and application of the provisions of the Revised Treaty and all other subsidiary legal instruments adopted by Community. For more on the Community Court of Justice, see http://www.courtecowas.org/site2012/index.php?option=com content\&view=article\&id=2\&Itemid=5.

${ }^{41}$ Article 6(1)(f), 17-19. In 2007, the Secretariat of the Economic Community of West African States (ECOWAS) with its headquarters in Abuja was transformed into a Commission headed by a president, assisted by a vice-president and Commissioners. For more on the ECOWAS Commission, see http://www.comm.ecowas.int. 
Cooperation, Compensation, and Development; ${ }^{42}$ Specialised Technical Commissions; ${ }^{43}$ and any other institutions that may be established by the Authority.

These fundamental institutional changes in the community were also accompanied by amendments to the binding force of the Community Decisions. ${ }^{44}$ The Revised ECOWAS Treaty clarifies the legal status of the decisions of the Authority and Council of Ministers. The Authority (the supreme organ of ECOWAS) under the Establishing Treaty was responsible for the "general direction and control of the performance of the executive functions of the community." 45 While the "crucial task of harmonising and co-ordinating the socio-economic policies and activities of the Member States could be deduced from this broad definition," the CEP recommended that "it would be desirable, for the avoidance of doubt and for proper appreciation of the role of the Authority in the integration process" to explicitly provide for such functions in the treaty. ${ }^{46}$ Pursuant to Article 7(2) the Authority shall, inter alia, oversee the functioning of the Community institutions and follow up on the implementation of Community objectives as well as making determinations on the general policy and major guidelines of the Community. Further, Article 7(3)(a) provides that the Authority shall "determine the general policy and major guidelines of the Community, give directives, harmonise and co-ordinate the economic, scientific, technical, cultural and social policies of Member States." ${ }^{47}$ The

\footnotetext{
${ }^{42}$ Article 6(1)(g), 14.

${ }^{43}$ Article 6(1)(h).

${ }^{44}$ CEP Final Report, 15. See, Kufuor, Institutional Reforms, The Institutional Transformation of the Economic Community of West African States.

${ }^{45}$ Article 5(2)

${ }^{46}$ CEP Final Report, p. 14.

${ }^{47}$ In drafting this provision, the CEP drew inspiration from the provisions of the EEC and Article 8(3) of the African Economic Community that explicitly confers its supreme organ with the power to "give
} 
Authority is now also empowered to request the Community Court of Justice to provide advisory opinion on any legal questions. ${ }^{48}$

Whereas under the ECOWAS Establishing Treaty, the Council of Ministers, the subordinate organ to the Authority, lacked the original or delegated power to execute tasks - harmonization and coordination of the socio-economic policies and activities of Member States - that are considered crucial to the operation of ECOWAS, the Revised ECOWAS Treaty adopted the recommendation of the CEP that "appropriate powers should be given to the Council, by way of delegation from the Authority, in appropriate cases, to give directions to Member States, particularly in the crucial area of policy harmonisation and co-ordination." 49 The powers of the community institutions and ECOWAS Commission were also enhanced to ensure that ECOWAS's performance was improved and that a more effective ECOWAS would emerge that would not only deepen integration but also enhance economic development in the West African region.

The foregoing represents the significant changes that the Revised ECOWAS Treaty introduced. To summarize, the Revised ECOWAS Treaty, like the new regionalism, is everything that the ECOWAS Establishing Treaty was not: outward looking, a response to the changed economic order since the 1980 s, driven by a range of state and non-state actors, and has as its goal the achievement of an Economic Union. It introduces important changes to the legal and institutional framework of ECOWAS. In particular, ECOWAS is

directives, co-ordinate and harmonise the economic, scientific, technical, cultural and social policies of Member States." CEP Final Report, Ibid.

${ }_{48}$ Article 7(3)(h). See generally Henry Ukaigwe, ECOWAS Law (London: Springer, 2016).

${ }^{49}$ Article 10(3)(c). In making this recommendation, the Commission drew insight from the provisions of the African Economic Community. 
reconceptualized as a supranational institution with institutions to implement its objectives. The commitment to supranational authority reaffirms without doubt the legal formalism that underpins it. To be sure, the mere establishment of new institutions is not synonymous with effectiveness in the implementation of the Revised ECOWAS Treaty, as the institutions are "themselves informed and structured by a particular ideology and normative assumptions. ${ }^{, 50}$ In other words, it is important to realize that the institutions and the way they function are embedded in local socio-political contexts that are often not taken cognizance of in the design of the institutions.

It also expressly recognizes the importance of the private sector in the new order. According to Okechukwu Iheduru, the new ECOWAS is "unlike the era of 'club' diplomacy when regionalism was the exclusive preserve of competing nation-states....[It] is an inclusive or 'holistic regionalism' in which the desire for a regional community is a persistent goal not only in official state discourse, but also, propagated by non-state actors." ${ }^{51}$ The divergence in the textual commitments of the Member States in the treaty and its actual implementation indicate the continuing influence of the socio-political factors at the international and regional levels. Unlike the founding treaty, the Revised ECOWAS Treaty signals a complete shift towards a strong regional centre, perhaps, in the shape of a partial-supranational organization as crucial to the aspirations of achieving regional economic integration.

\footnotetext{
${ }^{50}$ See Mayeda, "Appreciate the Difference: The Role of Different Domestic Norms in Law and Development Reform", 547-98, 558.

${ }^{51}$ See Okechukwu C. Iheduru, "The New ECOWAS: Implications for the Study of Regional Integration," in Companion to Regionalism, ed. Timothy M. Shaw, J. Andrew Grant, and Scarlett Cornelissen (Farnham: Ashgate Publications, 2011), 216.
} 
Despite the ambitious nature of the commitments, they could be far reaching if they were implemented as described. However, to date the implementation of the EOWAS Treaty has reinforced the claim in this thesis that ECOWAS is embedded in the socio-political and social conflict of the Community and that the international order and the power dynamics within the Community shape the trajectory of the organization. Further, although the Committee of Eminent Persons invoked the socio-political context of the ECOWAS Community as different from the EU, the invocation appears not to have gone beyond rhetorical acclamation as the majority of their recommendations were tailored after the EU, and the practice of the Member States, at least with respect to the protection of political and economic sovereignty, has not diverged significantly from the previous ECOWAS era.

In the next section, I examine the incremental evolution of the powers of the ECOWAS Community Parliament as part of the broader claim that the implementation of the Revised ECOWAS Treaty is being shaped by international and regional socio-political contexts in which it is embedded. ${ }^{52}$

\subsection{The ECOWAS Parliament}

The trajectory of the ECOWAS Parliament and its culmination in the most recent supplementary protocol illustrates the extent to which the implementation of the Revised ECOWAS Treaty and its institutions are simultaneously influenced by regional social conflict and the good governance narratives at the international level. The evolution of

52 See Mayeda, "Appreciate the Difference: The Role of Different Domestic Norms in Law and Development Reform," 559-562. 
the Community Parliament's powers should thus not be seen as organic. It demonstrates the continuing influence of international socio-political norms promoted by the World Bank and international donor institutions.

The Community Parliament is one of the key institutions established by the Revised ECOWAS Treaty. ${ }^{53}$ The Protocol elaborating on the establishment of the Community Parliament was adopted in $1994^{54}$ and amended in $2006 .{ }^{55}$ A further Supplementary Act enhancing the powers of the Community Parliament was adopted in $2016 .{ }^{56}$ The ECOWAS Community Parliament is described as a "forum for dialogue, consultation and consensus for representatives of the peoples of the Community, [that] can effectively promote integration. ${ }^{, 57}$ This fits with the traditional role of such regional parliaments. However, the ECOWAS Community Parliament also has the competence to consider any matter concerning the ECOWAS Community, including but not limited to human rights and fundamental freedoms, and can make recommendations to the institutions of the Community ${ }^{58}$ The opinion of the Community Parliament may be sought with respect to broad regional issues, such as communication links between Member States aimed at making free movement of persons and goods effective; telecommunications; energy; cooperation in the area of radio; television and other media links within the Community

\footnotetext{
${ }^{53}$ Article 13(1). See ECOWAS Parliament, http://parl.ecowas.int/en/home/.

54 Protocol A/P.2/8/94 Relating to the Community Parliament, http://documentation.ecowas.int/download/en/legal documents/protocols/Protocol $\% 20$ Relating $\% 20$ to $\% 20 t$ he $\% 20$ Community $\% 20$ Parliament.pdf.

${ }_{55}^{55}$ See Supplementary Protocol A/SP.3/06/06 Amending Protocol A/P.2/8/94 Relating to the Community Parliament, http://documentation.ecowas.int/download/en/legal documents/protocols/Supplementary $\% 20$ Protocol $\% 20$ Amending\%20the\%20Protocol\%20Relating\%20to\%20the\%20Community\%20Parliament.pdf.

${ }^{56}$ See Supplementary Act A/SA.1/12/16 Relating to the Enhancement of the Powers of the ECOWAS Parliament, 17 December 2016.

${ }^{57}$ Preamble, Protocol Relating to the Community Parliament.

${ }^{58}$ Article 6(1).
} 
and between the Community and the rest of the World; public health policies; educational policy; youth and sports; scientific and technological research; community policy on environment; treaty review; Community citizenship; social integration; and respect for human rights and fundamental freedoms. ${ }^{59}$

However, as originally constituted, three criticisms have been proffered against the Parliament. First, from its establishment, the Community Parliament was a weak institution and a Parliament only in name because it lacked legislative capacity and with it the ability to influence policy. Second, the advisory procedure was not mandatory. In effect, the Community institutions have the discretion to choose whether or not to adopt opinions delivered by Parliament. Third, the Community was understaffed and therefore had little ability to carry out its day-to-day activities. Pursuant to a Regulation of the Authority, directives were given for the restructuring of the Community Parliament in order to position it for effective participation in the ECOWAS decision-making process and to create the necessary synergy and cooperation between the Parliament, the organs of the Community and the Member States. ${ }^{60}$ The directives contained in the Regulation "were aimed at establishing a restructured Parliament with a distinct political arm and an administrative wing adequately staffed by competent professional and administrative personnel that will provide the necessary administrative services for the work of the members of the Parliament." ${ }^{61}$ In particular, Supplementary Protocol A/SP.3/06/06 amended relevant provisions of Protocol A/P2/8/94 with a view to establishing greater harmony between the activities of the Parliament and the Community organs, as well as

\footnotetext{
${ }^{59}$ See generally Article 6(2)(a-m).

${ }^{60}$ See ECOWAS Regulation C/REG.20/01/05.

${ }^{61}$ See Preamble to Supplementary Protocol A/SP.3/06/06.
} 
elevating its mandate from advisory to co-decision makers. For example, "the powers of the ECOWAS Parliament shall be progressively enhanced from advisory to co-decision making and subsequently to a law-making role in areas to be defined by the Authority." This gradual evolution in the powers of the Community Parliament are indeed consistent with the aspirations of the CEPs. ${ }^{63}$ So far, the ECOWAS Parliament has had three legislatures. Currently in its Fourth Legislature, each with a mandate of four years, the present ECOWAS Parliament has sought to improve on the efforts of the past legislature. Looking to consolidate on the gains of the previous legislatures and improve the overall performance of the Parliament, the Fourth Legislature Rules of Procedure relating to the conduct of sessions, structure, committees, organization of the business of the ECOWAS Parliament, discipline, quorum and voting, openness and transparency, public record of proceedings, petitions and relations with the institutions of the Community, national parliaments and international organizations were adopted in $2016 .{ }^{64}$ The Fourth Legislature Strategic Plan provides a new policy framework for the programs, vision, mission, goals, objectives, and activities of the current Parliament. ${ }^{65}$ The plan takes into account "the main political, economic, social and environmental changes taking place in the sub region and globally, as identified by the Community Strategic Framework." ${ }^{\prime 66}$ The goals of the Strategic Framework are structured around five themes: socio-economic development, economic and monetary integration, political integration,

\footnotetext{
${ }^{62}$ See Article 4(2). (Amending Article 6 of the 1994 Protocol).

${ }^{63}$ Final Report, 24. Also see Linda Boré and Felix Henkel, "Disturbing a Cosy Balance? The ECOWAS Parliament Rocky Road to Co-Decision," Friedrich Ebert Stiftung International Policy Analysis, January 2015, 1-8, online http://library.fes.de/pdf-files/iez/11185.pdf.

${ }^{64}$ See Fourth Legislature Rules of Procedure, adopted 8 February 2016, http://parl.ecowas.int/en/rules-ofprocedures/.

${ }^{65}$ For the future directions of the ECOWAS Parliament, see generally ECOWAS Parliament, "Strategic Plan of the Fourth Legislature of the ECOWAS Parliament (2016-2020)," http://parl.ecowas.int/en/strategic-plan/.

66 "Strategic Plan," 3.
} 
societal/institutional support, expansion and improvement of infrastructural facilities. ${ }^{67}$ Building on the legislative agenda of the Third Legislature, the Strategic Plan considered the prospects for the enhancement of the powers of the Parliament. The result was the emergence of a draft Supplementary Act on the enhancement of the Parliament's powers. Poised to reposition the Community Parliament as a relevant institution for the ECOWAS Member States and their citizens, the further amendment enhancing its powers was adopted in 2016. ${ }^{68}$ The Community Parliament has now been redesignated as the ECOWAS Parliament. ${ }^{69}$

The objectives of the Parliament have been significantly reformulated to include the following: contribute to the efficient and effective implementation of the objectives and policies of the Community, strengthen democracy, cooperation, regional solidarity, and advancement with a view to building a sense of common destiny in the Community; contribute to the promotion of peace; security; human rights; democracy, the rule of law; transparency; accountability; good governance and stability in the region; promote collective self-reliance and sustainable economic development; reinforce the legitimacy of the actions taken by the Community Executive with respect to regional integration; participate in the process of enacting Community Acts; and co-operate with national and regional parliaments, similar bodies within and outside West Africa as well as civil societies with a view to promote regional integration. ${ }^{70}$ [Emphasis mine.] Further to this

\footnotetext{
${ }^{67}$ Ibid., 15.

${ }^{68}$ See ECOWAS Parliament, "Final Communiqué of the 50th Ordinary Summit of the Authority of Heads of State and Government," 17 December 2016, http://parl.ecowas.int/en/final-communique-of-the-50thordinary-summit-of-the-authority-of-heads-of-state-and-government/.

${ }^{69}$ Article 2.

${ }^{70}$ Article 4(a-m).
} 
amendment, the ECOWAS Parliament also now has areas of mandatory and nonmandatory referrals. This is one of the avenues through which the ECOWAS Parliament exercises oversight functions over the Community.

Referrals are mandatory to the Parliament where the issues relate to the Community budget; revision of the Treaty and its annexes; annual audit reports of Community Organs and Institutions; adoption or review of all Community Acts relating to ECOWAS Economic and Monetary Integration, including trade, customs, free movement of persons, goods and services, infrastructure, monetary cooperation, industry and mining, private sector and investment promotion; and any sectoral policy decided by the Authority. ${ }^{71}$

Referrals are non-mandatory where they pertain to international agreements affecting the Community institutions; membership, suspension, sanction, or exclusion of Member States by the Community; creation of institutions, and the community defence, peace and security policies. ${ }^{72}$ Once a matter has been referred to the ECOWAS Parliament, it can deal with it in three ways: simple (non-binding) opinion, mandatory (binding) assent, and finally, co-decision-making, as well as co-legislation with the Council. The latter two forms of decision-making were not previously within the scope of Parliamentary powers and thus provide the ECOWAS Parliament with wider purview within which to act in the Community. Co-legislation between the ECOWAS Parliament and the Council of Ministers, for example, is restricted to economic and monetary integration policies.

\footnotetext{
${ }^{71}$ Article 9(a-f).

${ }^{72}$ Article 10(a-d).
} 
The gradual evolution or incremental expansion of the powers of the ECOWAS Parliament and the Community Court of Justice (examined in the next chapter), are indicative of the influence of the good governance narratives, particularly, with respect to democratic commitments, human rights protection, rule of law, and accountability. As earlier contended, the good governance narratives have not only shaped the revision of the ECOWAS Treaty but continue to influence its implementation and the activities of its institutions. Although it is not the ambition of this thesis to make a determination on the capability of the ECOWAS Parliament to carry out the good governance proposals, this does not remove from the fact that, rather than emphasize the role of the Parliament in advancing regional economic integration objectives, the door has now been opened to wider socio-political factors that map to the good governance proposals. ${ }^{73}$

As social conflicts and political instability leading to human rights violations increase, the trajectory of ECOWAS Parliament, at least as enshrined in the protocols, is shifting away from a primary trade liberalization and economic integration enhancing Parliament. In fact, with the determination of core economic integration rules reserved for the Authority, it is difficult to imagine how the Parliament would have a meaningful contribution to ECOWAS in this regard outside of the broader socio-political contexts that are now reflected in its latest supplementary protocol. The sustained influence of the good governance narratives on the implementation of Revised ECOWAS Treaty is strengthened by the adoption in 2001 of the ECOWAS Good Governance Protocol as a supplementary protocol to the Mechanism of Conflict Prevention, Management,

\footnotetext{
${ }^{73}$ See H. Hwasi Prempeh, “Africa's 'Constitutionalism Revival': False Start or New Dawn?” (2007) 5:3 International Journal of Constitutional Law, 469-506.
} 
Resolution, Peacekeeping and Security. ${ }^{74}$ The point from the foregoing is that the Revised ECOWAS Treaty and the institutions created thereunder have evolved and are being influenced by the socio-political developments in the regional and international community.

\subsection{Retelling the Socio-Political Context of the Implementation of the Revised ECOWAS Treaty}

While the Revised ECOWAS Treaty was adopted to reinforce the commitment of ECOWAS Member States to economic integration, "in practice, the second phase of ECOWAS [has] been dominated by security, good governance and human rights concerns." 75 As Celine Tan observes, "socio-legal scholarship places power at the heart of the study of law and legal institutions, paying close attention to the mechanisms by which power structures social and economic life." ${ }^{, 76}$ In the remaining sections of this chapter, I deepen the analysis of the influence of social conflict, good governance rhetoric, and power dynamics in the region on the implementation of the Revised Treaty.

\footnotetext{
${ }^{74}$ See Protocol Relating to the Mechanism for Conflict Prevention, Management, Resolution, Peacekeeping and Security, 1999; also see Protocol A/SP1/12/01 on Democracy and Good Governance Supplementary Protocol relating to Mechanism for Conflict Prevention, Management, Resolution, Peacekeeping and Security.

${ }^{75}$ Alter et al., "A New International Human Rights Court for West Africa: The ECOWAS Community Court of Justice," 744; also see Oli Brown, Faisal Haq Shaheen, Shaheen Rafi Khan, and Moeed Yusuf, "Regional Trade Agreements: Promoting Conflict or Building Peace?," International Institute for Sustainable Development, October 2005, 1-20, https://www.iisd.org/pdf/2005/security rta conflict.pdf.

${ }^{76}$ Tan, "Navigating New Landscapes: Socio-legal Mapping of Plurality and Power in International Economic Law," 29.
} 


\subsubsection{Tension between Regional Supranational Pull and National Sovereignty}

The commitment to supranational status represents one of the key areas that unsettles the social interactions of ECOWAS Members and complicates the implementation of the Revised ECOWAS Treaty. The Revised Treaty is said to have fundamentally reconstituted ECOWAS from an intergovernmental organization to a supranational one. ${ }^{77}$

A supranational organization has powers to make decisions that not only bind its Member States but are also superior to its laws in the event of conflict. According to its Preamble, the Head of States of Governments of ECOWAS Member States "are convinced that the integration of the Member States into a viable regional community may demand the partial or gradual pooling of national sovereignties to the Community within the context of a collective political will." 78 The ECOWAS Court of Justice has affirmed the supranational status of ECOWAS in some of its decisions. In Musa Saidykhan v. Republic of Ghana, the Court stated that "ECOWAS is a supranational authority created by the Member States wherein they expressly ceded some of their sovereign powers to ECOWAS to act in their common interest. Therefore, in respect of those areas where the Member States have ceded part of their sovereign powers to ECOWAS, the rules made

\footnotetext{
${ }^{77}$ See Final Report of CEP, 7. Pages 16-21 of the report were dedicated to the discussion of supranationality in the context of ECOWAS. The efficacy of the ECOWAS Community Court of Justice as an important institution for the implementation of the supranational status of ECOWAS will be examined in the ensuing chapter 6.

${ }^{78}$ Preamble to Revised ECOWAS Treaty. Also see, See Laurence R. Helfer and Anne-Marie Slaughter, "Towards a Theory of Effective Supranational Adjudication" (1997) 107 Yale Law Journal, 273-291, 28788.
} 
by ECOWAS supersede rules made by individual Member States if they are inconsistent. ${ }^{, 79}$

According to Kufuor, the reasons for the shift towards a supranational institution under the Revised ECOWAS Treaty include: "global and regional factors; the desire for institutional efficiency; the search by ECOWAS' leaders for political legitimacy; and the consequence of continuing post-independence enthusiasm for regional co-operation in West Africa." ${ }^{80}$ These factors are echoed in the Final Report of the Committee of Eminent Persons that drafted the Revised ECOWAS Treaty, which elucidates some of these factors. From the point of view of the Committee of Eminent Persons, supranational powers are an indispensable instrument of effective integration ${ }^{81}$ Regarding the lack of supranational ECOWAS in the context of the Establishing Treaty, they note that

efforts towards the establishment of an economic community embracing all the states of the West African region were initiated in the early sixties, not long after most of the countries had emerged from colonial domination into independence and statehood. In this formative stage, the natural inclination of the countries was in the direction of consolidating their independence and preserving and enhancing national sovereignty. Additionally, inter-state relations in the region were generally plagued by deep suspicions and political and ideological differences. In these circumstances, prudence and pragmatism dictated a cautious approach to the sensitive issue of supranationality. ${ }^{82}$

In the context of the contemporary global factors of the 1990s, the Committee of Eminent Persons based their recommendation for a supranational ECOWAS on the ground that the

\footnotetext{
${ }^{79}$ See Musa Saidykhan v. Republic of Ghana ECW/CCJ/APP/11/07, paragraphs 48, 49 and 50 of Ruling of 30 June, 2009. National Association of Nigerian Traders (NANTS) Regional Trade Advocacy Series, "Sovereignty, Supra-nationality and Trade: The Case of ECOWAS Laws," Vanguard, Vol. 2, Issue 4, February 2013.

${ }^{80}$ Kufuor, The Institutional Transformation of the Economic Community of West African States, 143.

${ }^{81}$ Final Report of the Committee of Eminent Persons, 18.

82 "Consequently, the institutions that were agreed in the Treaty left national sovereignty intact, relying solely on the general undertaking of Member States to make every effort to plan and direct their policies with a view to creating favourable conditions for the achievement of the aims of the Community... and to...take all steps to secure the enactment of such legislation as is necessary to give effect to [the Establishing] Treaty." Final Report of the Committee of Eminent Persons, 16.
} 
process of globalization was transforming the contemporary nation-state. ${ }^{83}$ According to the Final Report, "perceptions about national sovereignty and the principle of noninterference in the internal affairs of other states are now undergoing gradual transformation as the world shrinks more and more into a global village." ${ }^{94}$ Augmenting the claim in this thesis that the changes and implementation of the Revised ECOWAS Treaty are shaped by international and regional socio-political contexts, the Final Report notes that

in the international economic sphere, the policy dialogues conducted by prospective aid recipient countries with international financial institutions such as the World Bank and the IMF make significant inroads into the concept of national sovereignty in its pristine form. Indeed, experience now shows that national independence and sovereignty are meaningless and that pursuit of economic development, especially by developing countries, quite often necessitates the concentration of efforts at the regional level. ${ }^{85}$

According to the Committee of Eminent Persons, "developments in post-war international economic relations reveal that the most potent strategy for countries to acquire economic clout is to pool their resources in an arrangement which requires at least a partial transfer of sovereignty to a supranational body in the larger collective interest." ${ }^{86}$ Based on the foregoing, the Committee of Eminent Persons made its recommendations for a supranational ECOWAS with a view to aligning the organization with current international economic practices as well as the African Economic Community Treaty that is a supranational organization. ${ }^{87}$

\footnotetext{
${ }^{83}$ Lloyd Gruber, Ruling the World: Power Politics and the Rise of Supranational Institutions, (Princeton University Press, 2000); Final Report of the Committee of Eminent Persons.

${ }^{84}$ Final Report of the Committee of Eminent Persons, 16.

${ }^{85}$ Ibid., 17.

${ }^{86}$ Ibid., 144

${ }^{87}$ Ibid., 19:
} 
As Kufuor rightly observes, there was "probably very little real demand for supranational institutions and organizations within ECOWAS" at the time it was amended. ${ }^{88}$ While this may be true, the challenge for implementation in ECOWAS is that supranationalism runs into tension with the historical and contemporary practices of ECOWAS Member States. In particular, supranational authority could weaken the ECOWAS Member States' economic and political sovereignty. It substantively requires member states of ECOWAS to surrender a measure of their sovereign powers to make political and economic decisions on their behalf. Colonial legacy and the protection of the status of regional hegemons are important historical factors that shape and make the black-letter implementation of the supranational commitment difficult. In addition, the social conflicts and distrust among member states have also not abated. In fact, as the more powerful regional members like Nigeria and Ghana contend to reposition themselves in the global village, the suspicions echoed by the Committee of Eminent Persons has deepened. From this point of view, the implementation of the supranational aspirations of Revised ECOWAS Treaty reifies and reproduces the structural inequalities within the ECOWAS Community.

The point here is that while the events that constrained the willingness of the Member States from creating a supranational authority in the 1970s differ from the 1990s, the attitude of the Member States with respect to the protection of their sovereignty, as accentuated by social conflicts and further marginalization in the new international economic order, is also being realigned. The complexity of supranational ECOWAS is

\footnotetext{
${ }^{88}$ Ibid., 17; Kufuor, The Institutional Transformation of the Economic Community of West African States, 54.
} 
examined further in the context of the "compliance" with the decisions of the ECOWAS Community Court in the next chapter where there is a mixed result, which makes it hard to say categorically that ECOWAS is indeed supranational.

To summarize, the claim here is that the supranational aspirations of the Revised ECOWAS Treaty runs into tension with the historical and socio-political practices of the ECOWAS Member States, who jealously guard their political and economic powers and are committed to also guarding against territorial incursion. While the international and regional socio-economic contexts of the contemporary world order differs significantly from the 1970s, the socio-political factors that prevented ECOWAS Members from committing to supranationalism in the 1970s have not abated. Hence, while the textual commitment of the Revised ECOWAS Treaty points towards a supranational organization, in practice, ECOWAS Member States have not changed, demonstrating the fact that the Revised ECOWAS Treaty remains embedded in the socio-political contexts of the West African Community.

\subsubsection{The Drowning Effect of Overlapping Membership and Conflicting Social Relations}

The Revised ECOWAS Treaty provision that it would ultimately be the sole regional economic community in West Africa is another area where the treaty diverges from the socio-political and historical realities of the West African sub-region and complicates the implementation conundrum. One of the widely acknowledged challenges to the effectiveness of regional economic cooperation in Africa broadly, and West Africa in particular, is the co-existence of many regional communities within a particular region 
and the overlapping membership of the many states. ${ }^{89}$ Framed as a critique, the argument is that multiple memberships create a strain in the commitment of the Member States as well as their capacity to meet the financial obligations of multiple organizations. ${ }^{90}$ The formation of overlapping regional organizations and membership is, in part, also a consequence of the historical francophone and anglophone division in West Africa along linguistic and cultural divisions and former colonies. The historical division between francophone and anglophone West African States continues today as part of colonial legacies in the region. ${ }^{91}$

Examining the role of social conflicts arising from overlapping membership illuminates some of the socio-political context of the implementation of Revised ECOWAS Treaty, particularly when situated in the historical francophone and anglophone division in West Africa. In 1994, francophone West African Member States undertook what is considered as "the earliest strategic repositioning efforts" in the region. ${ }^{92}$ To do this, two erstwhile separate economic groupings- Communauté économique des États de l'Afrique de l'Ouest (CEAO) and the Union monétaire ouest africaine (UMOA) - were merged to create "a more effective Union monetaire oust-africaine (UMOA) devoid of much of the

\footnotetext{
${ }^{89}$ See United Nations Conference on Trade and Development, "Regional Cooperation and Integration in Sub-Saharan Africa," Discussion Paper No. 189, September 2008. UNCTAD argues that one of the factors that makes "an empirical-based argumentation difficult is the widespread phenomenon of overlapping memberships in various regional blocs in Africa. Thus, it is not always possible to definitely attribute certain integration effects to coordination activities within one specific integration scheme." "Regional Cooperation and Integration in Sub-Saharan Africa," 3.

${ }^{90}$ See generally Mwita Chacha, "Regional Integration and the Challenge of Overlapping Memberships on Trade" (2014) 17:4 Journal of International Relations and Development, 522-44.

${ }^{91}$ See Sekou Camara, "Francophone Regionalism and its Impact on West African Integration" (master's thesis, Florida International University Electronic Theses and Dissertations, 2001).

${ }^{92}$ See Okechukwu C. Iheduru, "The New ECOWAS: Implications for the Study of Regional Integration," in The Ashgate Research Companion to Regionalisms, ed. Timothy M. Shaw, J. Andrew Grant, and Scarlett Cornelissen (New York: Routledge, 2012), 213-239, 217.
} 
rabid economic nationalisms of the past." ${ }^{.93}$ This development occurred barely a year after the adoption of the Revised ECOWAS Treaty. Given the historical underlying colonial and post-colonial division, and more recent social conflicts, this is symbolic of the fact that the division, which remains intertwined with the socio-economic and political interactions of the countries today, has not abated. The simultaneous strengthening of both ECOWAS and West African Economic and Monetary Union (UEMOA) has directly frustrated, if not rendered unnecessary, ECOWAS's aspiration of ultimately being the sole economic union in the West African sub-region. ${ }^{94}$ On the one hand, UEMOA has since implemented macroeconomic convergence criteria and an effective surveillance mechanism (especially of budgetary discipline); adopted a customs union and common external tariff (early 2000); harmonized indirect taxation regulations; and initiated regional structural and sectoral policies"; and is recognized as being "furthest along the path toward integration." ${ }^{95}$ On the other hand, ECOWAS has been slower in making similar progress. The faster pace of integration in the UEMOA, particularly with respect to monetary union and common currency, constitutes a challenge in the implementation of Revised ECOWAS Treaty. ${ }^{96}$ Although some scholars have argued that this provides an alternative regional cooperation scheme, such an argument is limited in that the linguistic

${ }^{93}$ Ibid.

${ }^{94}$ Article 3(1) Revised ECOWAS Treaty.

${ }^{95}$ Ibid.; International Monetary Fund, IMF Fact Sheet 2005, (2005a; Washington, DC).

${ }^{96}$ According to V. Chambers, M. Foresti, and D. Harris, As all UEMOA member states are also ECOWAS member states, there has been a tendency to concentrate on ECOWAS when considering the issue of regional integration in West Africa. However UEMOA is still a significant regional actor and one, which has been, arguably more successful than ECOWAS at overcoming the coordination problems critical to integration processes. Furthermore there are few signs that consolidation under ECOWAS will happen in the short term. On the contrary, recent moves by UEMOA to develop its regional policy coordination competences indicate it is moving away from, rather than towards, greater integration with ECOWAS.

See V. Chambers, M. Foresti, and D. Harris "Final Report: Political Economy of Regionalism in West Africa—Scoping Study and Prioritisation” (London: ODI, 2012), 17. 
cohesiveness is not common to all ECOWAS members. In particular, Nigeria, the largest economy in West Africa is strictly Anglophone. The inability of the largest economy in the region to participate weakens the argument that the UEMOA is an alternative for the ECOWAS Member States. In fact, it reinforces the unequal social structure, historical colonial division in the region, heightens the distrust in the region as Member States compete, and adds to the complexity of the context for implementation of the aspirations of the ECOWAS Treaty. The direct implication is that ECOWAS's goals of increasing economic cooperation, common market, and single currency are made much more difficult than would have appeared from a simple textual analysis of the treaty.

Based on the foregoing, legislating ex nihilito that a single regional economic community shall henceforth exist despite the historical, economic, political, and social differences of the Member States is likely to be practically unworkable. On the contrary, the implementation of the Revised ECOWAS Treaty has reinforced rather than eliminated the co-existence of different regional economic communities in francophone and anglophone West Africa. The West African Economic and Monetary Union (UEMOA)the primary francophone community—has continued to exist simultaneously with ECOWAS. ${ }^{97}$ Interestingly, both organizations have found ways to collaborate and cooperate over regional projects instead of seeking ways to become a single community. ${ }^{98}$ Given the continued coexistence and collaboration between them, the

\footnotetext{
${ }^{97}$ The UEMOA represents some of the francophone West African Countries and has some ECOWAS Member States as contracting parties as well. The members of the UEMOA are Benin, Burkina Faso, Côte d'Ivoire, Guinea Bissau, Mali, Niger, Senegal and Togo. See generally http://www.uemoa.int/Pages/Home.aspx.

${ }^{98}$ See for example, M'Gbra N'Guessan, “Technical Discussion Paper on General Energy Access in the ECOWAS Region: Towards Universal Energy Access Particularly in Rural and Peri-Urban Areas of the ECOWAS Region: Approaches, Opportunities and Constraints," Final Report, January 2012,
} 
desire that ECOWAS would ultimately be the sole economic community in West Africa remains at best aspirational. The ongoing cooperation of the organizations further illustrates the divergence in the aims and objectives of ECOWAS as expressed in its treaty and the context of its implementation in the Community.

\subsubsection{The Influence of Social Conflicts on the Implementation of the Revised ECOWAS Treaty}

The Revised Treaty also explicitly acknowledges that the political, economic, and sociocultural challenges that confront ECOWAS Member States differ and there is need to respect their diversities. ${ }^{99}$ The new paragraph underscores the complexity of the ECOWAS region and the associated socio-political and historical challenges they confront because of the heterogeneous composition of the Community. Heterogeneity may breed positive or negative consequences for the implementation of the regional economic cooperation objectives. In its positive context, heterogeneity across different fields may enhance regional cooperation in that the Member States might be able to leverage their diversified economic base as a spring board for economic development, the protection of their national sovereignty, as well as the enhancement of their regional bloc for the purpose of negotiation of international economic agreements.

Conversely, heterogeneity can also pose a challenge to regional cooperation. For example, economic disputes or actions of powerful Member States-regional

http://www.uncsd2012.org/content/documents/164Consolidated Document General Energy Access FIn al\%20(2).pdf. The objective of the policy is to ensure access to modern energy services to at least half the population living in rural and peri-urban areas by 2015 .

${ }_{99}$ In this regard, the Preamble provides that the review, among other reasons, is based "on the need for the Community to adapt to the changes on the international scene in order to derive greater benefits from those changes." 
hegemons - may escalate tensions in the social and historical relations of the Community that would make it difficult to leverage on the potential benefit of heterogeneity due to the absence of unity. Internal social conflicts within Member States can also have a spillover effect that impacts the cohesion of the Community, while external conflicts may arise as a consequence of the relations among the Member States and other countries. The ECOWAS Community has witnessed significant occurrence of social conflicts on various scales involving Liberia, Sierra Leone, and Côte d'Ivoire on the one hand, and Senegal, Mali, and Nigeria on the other hand.

To expatiate on the Liberian context under the late president Samuel Doe, the conflict predated the adoption of the Revised ECOWAS Treaty. Indeed, by the time ECOWAS officially intervened in 1990, the breakdown of law and order was almost complete with the country on the verge of collapse. ${ }^{100}$ However, the manner of ECOWAS's intervention has been controversial, with several allegations about the partisan roles ECOWAS Member States played in the process, and human rights violations that compounded the military operations. The Liberian civil war highlights the controversial and complex socio-political environment and the relations of Member States within which the Revised ECOWAS Treaty would be implemented. While the aim was to settle the conflict that led to the civil war, the involvement had a direct impact on the implementation of the ECOWAS Treaties.

Nigeria, a regional hegemon, provided the majority of the forces, while Ghana, Senegal,

\footnotetext{
${ }^{100}$ Thomas Jaye, Dauda Garuba, and Stella Amadi, eds., ECOWAS \& the Dynamics of Conflict and Peace Building (Dakar: CODESRIA, 2001).
} 
Gambia, Mali, Niger, and Burkina Faso, among others contributed to the complement. However, it was alleged that the Nigerian-dominated ECOWAS military force, with the support of some ECOWAS Member States, acted against the interest of the National Patriotic Front of Liberia, led by Charles Taylor, whereas Burkina Faso and Côte d'Ivoire supported Charles Taylor's struggle for Liberian presidency. ${ }^{101}$ The allegations escalated the embedded conflict in the social relations of the Community Members and the distrust that by now was also characteristic of the wider Community relations. Nigeria would not have been able to sustain its manoeuvring in the Liberian civil war and assert its interests in the process but for the power it has in the region —as the most populous and richest in the region with significant commitment towards ECOWAS to maintaining the status quo. $^{102}$

These conflicts have not abated; rather, they continue in various ways that distract and affect the social and economic relations in the region. The Boko Haram context in Nigeria provides an ongoing example of the new dimension of regional conflicts the ECOWAS Member States have to confront that impact the implementation of the Revised ECOWAS Treaty with respect to cross-border economic transactions and freedom of movement. ${ }^{103}$ With the complex history of Boko Haram as engrained in the

\footnotetext{
${ }^{101}$ Christopher Tuck, "Every Car or Moving Object Gone: The ECOMOG Intervention in Liberia" (2000) 4:1 African Studies Quarterly, 1-16. "Nigerian policy towards ECOMOG-its methods and objectiveswere therefore coloured by its fundamental antipathy toward Taylor's NPFL. Taylor, on the other hand, received support from Cote d'Ivoire and Burkina Faso as well as from further abroad, e.g., France and Libya."

${ }^{102}$ For the analysis of ECOWAS's involvement in other conflicts, see Dr. Gilles Olakounle Tabi, "The Role of ECOWAS in Managing Political Crisis and Conflict: The Cases of Guinea and Guinea-Bissau," Friedrich-Ebert-Stiftung, September 2010.

${ }^{103}$ See Ufiem Maurice Ogbonnaya, Kanayo Ogujiuba, and Nancy Stiegler, "Terrorism in Nigeria, Implication of Boko Haram's Movement for Security and Stability in the ECOWAS Sub-region" (2014) 23:2 African Security Review, 145-60.
} 
Sahel of the West African region and the assumption of a transnational dimension, the conflict significantly impacts the ability of the Member States or citizens to cooperate effectively along economic lines or complete meaningful cross-border transactions in the affected areas.

The point from the two examples above is that heterogeneity, in the negative context, could have several implications for regional economic cooperation in an ECOWAS Community that significantly comprises developing countries. Where the regional economic body becomes preoccupied with the improvement of insecurity in the region or settling rivalries with a view to ensuring political stability in the Member States, as has been for ECOWAS, these conflicts significantly affect the effective implementation of the regional aspirations of the organization. ${ }^{104}$

\subsubsection{The International Dimension of Power Relations: Renegotiation of the Economic Partnership Agreement}

Another area where the implementation of the Revised ECOWAS Treaty has been influenced by exogenous events is in the renegotiation of the Economic Partnership Agreement (EPA). It is interesting that most of the analysis of the influence of the European Union on ECOWAS has focused almost exclusively on the structural and foundational aspects. Yet, the EPA is implicated in the implementation of the ECOWAS Treaty. This section thus interprets the EPA as an important example of the international

\footnotetext{
${ }^{104}$ ECOWAS's intervention in the handover process of the former president of The Gambia to the new president provides another recent example of how ECOWAS's trajectory and the implementation of the treaty is beyond the core economic integration aspirations. See generally Hartman Christof, "ECOWAS and the Restoration of Democracy in The Gambia" (2017) 52:1 Africa Spectrum, 85-99.
} 
technologies of governance outside the World Bank and the International Monetary Fund with national and regional ramifications within the ECOWAS Community. To be sure, the purpose of this analysis is not to examine the substantive provisions of the EPA; rather, it is to situate its implementation as part of the Revised ECOWAS Treaty in the broad economic and socio-political contexts of the region. ${ }^{105}$

The negotiations on EPA between the European Union (EU) and African governments have been on since $2002 .{ }^{106}$ The EU's trade relations with the African, Caribbean, and Pacific countries were historically framed by a series of conventions, which granted unilateral preferences to the $\mathrm{ACP}$ countries on the EU market. Initially signed in the late 1970s and generally referred to as the Lomé Convention, by the late 1990s, the flaws of the previous agreements had become obvious, thus necessitating the need for renegotiation. The renegotiation arrangements were configured along regional economic communities. For West Africa, this included ECOWAS and the West African Economic and Monetary Union (WAEMU). The decision to renegotiate the EPA as a region was made in December 2001 at the ECOWAS Heads of State Summit. ${ }^{107}$ According to the European Commission:

\footnotetext{
${ }^{105}$ According to the European Commission, "the conclusion of the EPA negotiations should also be seen in the context of West Africa's effort to improve regional integration, which materialised, for instance, in the adoption and entry into force of the Economic Community of West African States Common External Tariff (CET) in January 2015." See European Commission, "The Economic Impact of the West Africa-EU Economic Partnership Agreement," 1-94, 4, https://www.tralac.org/images/docs/9814/the-economicimpact-of-the-west-africa-eu-economic-partnership-agreement-march-2016.pdf.

${ }^{106}$ See Dirk Kohnert, "African Agency and the EU-African Economic Partnership Agreements" (2014) 49:3 African Spectrum, 149-55; Dirk Kohnert, Contemporary Politics (2014), 20:1, Special Issue: Perspectives on the Trade-Development Nexus in the European Union London: Routledge, ISSN: 13569775 (print), 1469-3631 (online), $126 \mathrm{pp.}$

107 European Commission, "The Economic Impact of the West Africa-EU Economic Partnership Agreement,", 9.
} 
The conclusion of the EPA negotiations can also be seen in the context of West Africa's efforts to improve regional integration, which materialised, for instance, in the adoption of the ECOWAS Common External Tariff (CET) for entry into force in January 2015. Regional integration efforts are a key element of West Africa's future trade patterns, aiming at creating a wider integrated market, which will attract investors and increase revenue prospects for local production. The EPA, coupled with the EU's overall strategy to support regional integration, aims at helping West Africa also in the technical and policy aspects of economic integration. $^{108}$

After over ten years of negotiations, the agreement was initialled in 2014 and subsequently endorsed by the ECOWAS Summit in $2014 .{ }^{109}$ The rationale for the negotiation was to foster "the smooth and gradual integration of the ACP States into the world economy with due regard for their political choices and development priorities, thereby promoting their sustainable development and contributing to poverty eradication in the ACP countries." ${ }^{110}$ However, as Dirk Kohnert notes, significant issues were at stake and have been especially pronounced in the negotiations on West African EPAs. According to him, "the EU became increasingly impatient with 'intransigent' African partners. It finally threatened to cancel the unilateral trade preferences enjoyed by Europe's former African colonies if the deadline of 1 October 2014 for the ECOWAS EPA was not honoured. Finally, on 10 July 2014 the heads of all ECOWAS member states endorsed the compromise EPA after prolonged negotiations at the organization's 45th ordinary session in Accra."

Two inferences can be drawn from the above: first, interpreted broadly, the EPA is part of the constellation of events that manifest under the umbrella of globalization and

\footnotetext{
108 European Commission, "The Economic Impact of the West Africa-EU Economic Partnership Agreement," 17.

109 Ibid., 9.

${ }^{110}$ Ibid., p. 16.
} 
through which trade agreements of its type are promoted across developing countries. However, given the paucity of trade among African countries, and the ECOWAS Community Members in particular, it appears that the EPA is not necessarily geared for promoting the economic development of the ECOWAS Member States because it reinforces the North and South model form of such agreements and reproduces the very pattern of trade that West African countries have become trapped in: raw materials in exchange for finished products. According to GRAIN, "the promises in the EPA are not any different from the ones that we saw and heard during the much-heralded great things to come that were housed in the now failed Structural Adjustment Programmes (SAPs) effects of which are still being felt today! Both are rooted within a colonial framework, which allows transnational corporations of the EU and the global North to extract raw materials from these countries under their own terms. As with all FTAs, the EPAs need to be analysed and understood as a series of interlinked events that are negotiated one after another with the sole purpose of crippling emerging economies." ${ }^{111}$ It is therefore unsurprising that ECOWAS Member States have not been eager to conclude the agreements. Secondly, it is directly linked to the effectiveness of ECOWAS's trade liberalization program. The EPA fosters the class of international trade agreements that entrench open market and deepen economic integration between developing countries and the developed world.

However, from a social conflict perspective, the EPA raises issues that destabilize the social relations of ECOWAS Community Members. The mainstream opinion is that a

\footnotetext{
${ }^{111}$ GRAIN, "Colonialism's New Clothes: The EU's Economic Partnership Agreements with Africa," 21 August 2017, https:/www.grain.org/article/entries/5777-colonialism-s-new-clothes-the-eu-s-economicpartnership-agreements-with-africa.
} 
new EPA would reduce social conflict in the region and that it has the potential to advance overall economic development. However, the point here is that the renegotiation has muddled the social interactions of the Community members. The EPA advances the EU's normative power over many of the poor states in West Africa, and promotes universal norms embedded in the agreements that are different from the socio-political realities of the partner states. Furthermore, the hegemonic and "civilizing power" of the EU in the discourse of regionalism cannot be overlooked in the negotiation process as the majority of the West African partners negotiate from a point of weakness. In addition, one size does not fit all; the promotion of the EPA template by the EU negates the heterogeneity of ECOWAS Community Members. ${ }^{112}$

While the majority of the poorer states within ECOWAS provisionally signed the Agreement, Nigeria, Ghana, and Côte d'Ivoire delayed. ${ }^{113}$ Pending the adoption of the regional EPA with Nigeria, Côte d'Ivoire and Ghana signed the Stepping Stone Economic Partnership Agreements in the last quarter of $2016 .{ }^{114}$ At the writing of this thesis, Nigeria and The Gambia have not ratified the EPA, hence, they are holding up the ratification of the regional EPA. In the rationale offered by Nigeria for delaying its signature lies an important insight that the regional hegemons were more concerned about

112 Silke Trommer, Transformations in Trade Politics: Participatory Trade Politics in West Africa (London: Routledge, 2014).

113 "Buhari: Why Nigeria is Yet to Sign Economic Partnership Agreement with EU," Business Times Nigeria, http://www.businesstimes.com.ng/buhari-why-nigeria-is-yet-to-sign-economic-partnershipagreement-with-eu/; also see Staff, "Nigeria will Lose \$1.3trn to ECOWAS-EU backed Economic Partnership Agreement-[Manufacturers Association of Nigeria]," Daily Post, 19 September 2016, http://dailypost.ng/2016/09/19/nigeria-will-lose-1-3trn-ecowas-eu-backed-economic-partnershipagreement-man/.

${ }^{114}$ See European Union, "EU Welcomes Ghana's Signing and Ratification of the EPA," 5 August 2016, https://eeas.europa.eu/headquarters/headquarters-

homepage en/7766/EU\%20welcomes\%20Ghana\%27s\%20signing\%20and $\% 20$ ratification $\% 20$ of $\% 20$ the $\%$ 20EPA; European Commission, “West Africa," http://ec.europa.eu/trade/policy/countries-andregions/regions/west-africa/. 
the benefit for the national economic development, as opposed to the greater good of all or majority of the ECOWAS Member States. ${ }^{115}$ According to a report authored by Global Network,

Nigeria's stance on EPAs is simple: the government will only negotiate a deal if the rules that emerge accommodate the country's trade and development objectives as well of those of the ECOWAS sub-region. However, real doubts have been expressed-both in government circles - as well as unions and civil society organisations about whether the present EPA can realistically promote these goals. ${ }^{116}$

The report by Global Network argues that the text not only contradicts the advancement of Nigeria's trade ambitions, but also positively thwarts them. ${ }^{117}$ This has a domino effect in ECOWAS. Nigeria is the biggest barrier to the EPA Agreement and is a nonbenevolent leader. ${ }^{118}$ In other words, while Nigeria may be seen to encourage other nations within ECOWAS to participate in regional economic governance, they have not always acted with the best interest of the entire community at heart. The activities of regional powers, such as Nigeria, are crucial for the success or failure of regional economic community initiatives. ${ }^{119}$ The tension generated within the ECOWAS Community because of the negotiation of the EPA has not gone unnoticed. In this regard,

\footnotetext{
${ }^{115}$ Samuel Oloruntoba, Regionalism and Integration in Africa: EU-ACP Economic Partnership Agreements and Euro-Nigeria Relations (New York: Palgrave Macmillan, 2016).

116 See Global Network, "Economic Partnership Agreements-The Case of Nigeria," 5, http://www.solidar.all2all.org/IMG/pdf/b9 trade unions and ngos response to epa nigeria.pdf.

${ }^{117}$ Ibid. Also see O. Nnenna, "ECOWAS Discusses Nigeria's Reservations on Economic Partnership Agreement," 7 September 2016, https://von.gov.ng/ecowas-discusses-nigerias-reservations-on-economicpartnership-agreement/.

${ }^{118}$ Merran Hulse, "Regional Powers and Leadership in Regional Institutions: Nigeria in ECOWAS and South Africa in SADC," KFG Working Paper Series, No. 76, November 2016, Kolleg-Forschergruppe (KFG) "The Transformative Power of Europe“, Freie Universität Berlin, http://www.polsoz.fuberlin.de/en/v/transformeurope/publications/working paper/wp/wp76/WP 76 Hulse PRINT.pdf.

${ }^{119}$ See Sebastian Krapohl, Katharina L. Meissner, and Johannes Muntschick, "Regional Powers as Leaders or Rambos? The Ambivalent Behaviour of Brazil and South Africa in Regional Economic Integration" (2014) 52: 4 Journal of Common Market Studies, 879-95.
} 
three strains on the socio-economic relations of the ECOWAS Member States have been identified: incoherence arising from contradictions with some of the tariff agreements between the EU, UEMOA CET (Ivory Coast), and the ECOWAS CET (Ghana); undermining regional unity; and the possibility of a bottom-up approach to regional integration. $^{120}$

\subsubsection{Power Relations: The Regional Context}

The Revised ECOWAS Treaty also provides for the creation of a Common Market and eventually an Economic Union, which means Member States would commit to imposition of few or no duties on trade with one another as well as an adoption of a common tariff on trade with other countries. However, marred by underlying social conflicts in the economic relations of the Member States, national sovereignty, weak economic performances, and pervasive protectionism, the realization of the ECOWAS common market and economic union aspirations have not sailed smoothly.

Kofi Oteng Kufuor's analysis of the tension in the economic relations between Nigeria and Ghana following Ghana's refusal to lower trade barriers offers a compelling example of the frosty social relations between ECOWAS Member States that affect the effectiveness of the implementation of the aims and objectives of the Revised ECOWAS

${ }^{120}$ Jakob Engel and Marie-Agnès Jouanjean, "Political and Economic Constraints to the ECOWAS Regional Economic Integration Process and Opportunities for Donor," Overseas Development Institute, February 2015 , https://assets.publishing.service.gov.uk/media/57a08997e5274a31e000017a/Political and Economic Cons traints to the ECOWAS.pdf. 
Treaty. ${ }^{121}$ The dispute relates to the rights of Nigerian traders to establish in the Ghanaian film industry. ${ }^{122}$ Due to a perceived influx of the films into the Ghanaian market, the country introduced additional tariff and permission from regulatory authorities for premieres of foreign films. ${ }^{123}$ Nigeria was significantly impacted by this measure as it became more difficult for its producers to penetrate the Ghanaian market. Although it does not appear to be a retaliatory measure, Kufuor notes that in 2004, Nigeria banned the importation of over ninety-six Ghanaian products, despite Ghana's complaint of difficulty in registering companies under the ECOWAS trade liberalization scheme. ${ }^{124}$

Clearly, merely legislating that ECOWAS intends to achieve a common market through trade liberalization is hardly a guarantee that members will align their national policies towards achieving this goal. On the one hand, the actions taken by Nigeria and Ghana contradict their undertaking to create favourable conditions for the achievement of the objectives of the Community and to honour the obligations under the Treaty. ${ }^{125}$ On the other hand, Ghana's refusal to ease the accessibility of Nigerian film-makers into its growing film industry also reflects the broader power dynamics of the social relations between Nigeria and Ghana. Since the Nigerian film industry is the biggest market in Africa, its incursion into Ghana, as with other smaller ECOWAS Community Member

\footnotetext{
${ }^{121}$ Kofi Oteng Kufuor, "When Two Leviathans Clash: Free Movement of Persons in ECOWAS and the Ghana Investment Act of 1994" (2013) 6:1 African Journal of Legal Studies, 1-16; also see K. O. Kufuor, "Sub-State Protectionism in Ghana" (2010) 18 African Journal of International and Comparative Law, 7891.

122 "At the centre of this clash between Ghanaian law and ECOWAS law are the terms of the Revised ECOWAS Treaty and its related Protocols, on the one hand, and Ghana's 1994 Investment Act, on the other." Kufuor, "When Two Leviathans Clash," 4.

${ }^{123}$ Ibid.

${ }^{124}$ Ibid.

${ }^{125}$ See Article 5 (General Undertakings); also see Stephen S. Golub, "Entrepot Trade and Smuggling in West Africa: Benin, Togo and Nigeria" (2012) The World Economy, 1-23.
} 
States, raises the sceptre of the impact of wider social conflicts on their economic relations.

\subsection{Conclusion}

The aim in this chapter was to analyze how the implementation of the Revised ECOWAS Treaty is being shaped by simultaneous socio-political factors at the regional and international levels. With the ECOWAS Establishing Treaty unable to address the contemporary challenges facing ECOWAS in the 1990s, the Revised ECOWAS Treaty replaced it. However, complex regional and international factors such as power dynamics, social conflict, and the promotion of good governance narrative have shaped not only the implementation of the Revised ECOWAS Treaty but also the trajectory of its institutions.

Although the implementation of the Revised ECOWAS Treaty is still ongoing, an important point that emerges from the analysis is that, to date, the implementation conundrum in relation to the ECOWAS economic aspirations has continued. Indeed, whereas the Revised ECOWAS Treaty expressly provides that the Member States shall pursue economic integration and economic cooperation, the pattern of the social relations of the Member States has followed the latter due to the social conflicts, Nigeria's interest as a regional hegemon, and the overall influence of the internationally promoted ideological perspectives of governance and development.

Although it may be argued that the implementation is ongoing, another point that emerges is that our understanding of the implementation conundrum with respect to 
economic integration is illuminated based on the analysis of the wider socio-political context that the Revised ECOWAS Treaty and its institutions are embedded. Together, they reinforce the claim in this thesis that the textual aspirations enshrined in ECOWAS Treaties are limited in accounting for the various complex factors that are contemporaneously influencing the organization. Finally, the implementation conundrum also highlights a gap between the Committee of Eminent Persons that drafted the Revised ECOWAS Treaty, the Member States who ratified and adopted it, and the representatives of these Member States or the Member States' action during the implementation phase. While the aim of this thesis was not to interrogate this triangular interaction, it is open for future empirical research to understand the nature of these relationships in order to broaden the knowledge base on ECOWAS. 


\section{Chapter 6}

\section{Revisiting the Expansion of the ECOWAS Community Court of Justice to Human Rights}

In this chapter, I continue the analysis of the evolution of the Revised ECOWAS Treaty institutions by examining the ECOWAS Community Court of Justice (Community Court). Initially established as a court that is primarily charged with the interpretation of the ECOWAS Community law and development of jurisprudence that would deepen economic integration in the region, the Court's jurisdiction has been expanded to complaints involving human rights violation. Rather than viewing the expansion to human rights as a natural evolution, I situate the human rights expansion of the jurisdiction of the Community Court as embedded in the social relations of the Community Members. In particular, I interpret the expansion as not only a manifestation of the regional factors, but of the broader constellation of international socio-political developments typified by new regionalism; the entrenchment of neoliberalism; the diffusion of human rights as a core element of good governance, and its interconnectedness to economic development. Like the Revised ECOWAS Treaty, whereas the Community Court was created to enhance economic integration, its trajectory both with respect to the substantive amendments to its protocol and the nature of the cases instituted before the Court is being shaped by good governance proposals and social conflicts in the Community. As the Community Protocols were adopted over a period of time that developmental state and neoliberalism overlap, I contend that a hybridity emerges that explicates our understanding of the continuing role of the state as the sole actor with respect to economic integration disputes before the Community Court. 
One influence of this hybridity on the role of the Community Court as an integrationenhancing body is that economic integration-related disputes have not been pursued at all before the Court. The chapter deepens and enriches the existing analyses on the trajectory of the Community Court.

\subsection{The ECOWAS Community Court}

The ECOWAS Community Court is underpinned by three different documents: two protocols and the Revised ECOWAS Treaty sandwiched between them. In 1991, ECOWAS Member States adopted a protocol for the establishment of a Community Court of Justice. ${ }^{1}$ Although the 1991 Protocol predated the adoption of the Revised ECOWAS Treaty in 1993, no concrete action had been taken by the Member States in relation to the actual establishment of the Court. In 2005, a Supplementary Protocol was adopted amending the 1991 Protocol. $^{2}$ In ensuing paragraphs, I provide a deeper analysis of the 1991 and 2005 Protocols, and the intricate socio-political contexts that led to the 2005 Protocol which expanded the jurisdiction of the Court. To the extent that they are not contradictory, I analyse them chronologically while drawing on the Final Report of the Committee of Eminent Persons to illuminate or supplement the background analysis.

The 1991 Protocol provides for the establishment of an ECOWAS Community Court of Justice. The Community Court will, among other responsibilities, ensure the "observance of law and of the principles of equity in the interpretation and application of the

\footnotetext{
1 See ECOWAS Community Court of Justice Protocol, (A/P/I/7/91), ('1991 Protocol'), http://www.courtecowas.org/site2012/pdf files/protocol.pdf.

${ }^{2}$ See Supplementary Protocol A/SP.1/01/05 Amending the Preamble and Articles 1, 2, 9, and 30 of Protocol A/P.1.91 Relating to the Community Court of Justice and Article 4 Paragraph 1 of the English Version of the Said Protocol, http://www.courtecowas.org/site2012/pdf files/supplementary protocol.pdf.
} 
provisions of the Treaty." As the "principal legal organ of the Community," the Court will adjudicate over disputes arising from the interpretation or application of the provisions of the Revised ECOWAS Treaty. ${ }^{4}$ The Community Court's jurisdiction can be invoked on the basis of a contentious matter or by way of seeking an advisory opinion. ${ }^{5}$ With respect to contentious matters, the Community Court has competence to deal with disputes that are referred to it by Member States or the Authority where such disputes arise between the Member States, or between one or more Member States, and the institutions of the Community with respect to the interpretation of the provisions of the ECOWAS Establishing Treaty. ${ }^{6}$ In the latter category, the Community Court can only assume jurisdiction after attempts to settle the dispute amicably may have failed. ${ }^{7}$ The Community Court also has jurisdiction to issue Advisory Opinions. ${ }^{8}$ Article 10(1) empowers the Community Court to issue advisory legal opinions as may be required by the Authority, Council, Member States, Executive Secretary (now Commission President) or any other institution of ECOWAS. ${ }^{9}$ However, actual steps were not taken towards the actual establishment of the Court. It is worth noting that the 1991 Protocol was adopted at a time when the ECOWAS Establishing Treaty, underpinned by developmental state ideology, was the treaty in place in ECOWAS.

\footnotetext{
${ }^{3}$ Article $9(1)$.

${ }^{4}$ Article 2, 1991 Protocol; and Article 76 (Settlement of Disputes), Revised Treaty.

${ }^{5}$ See respectively Article 9(2) Competence of the Court; and Article 10 Advisory Opinion, 1991 Protocol.

${ }^{6}$ Article 9(2).

${ }^{7}$ Article 9(3).

${ }^{8}$ See Request for Advisory Opinion by ECOWAS Commission, ECW/CCJ/ADV:OPN/01/05, and $E C W / C C J / A D V: O P N / 01 / 08$; ECCJ Press Release, "Legal Year: ECOWAS Court Advocates Effective Implementation of Community Law," 8 Monday October 2012, http://www.courtecowas.org/site2012/index.php?option=com content\&view=article\&id=143:legalyearpres sconference\&catid=14:pressrelease \&Itemid=36 (last visited 10 June, 2016).

${ }^{9}$ See generally Article 10(1-4), ECCJ 1991 Protocol.
} 
By 1993, the Revised ECOWAS Treaty was adopted. It incorporates a new provision for the establishment of both a Community Court of Justice and an Arbitration Tribunal for the Community. ${ }^{10}$ Rather than incorporate the 1991 Protocol, the Revised ECOWAS Treaty provides that the "status, composition, powers, procedure and other issues concerning the Court of Justice shall be set out in a Protocol." ${ }^{, 11}$ Article 15(4) provides that the decisions of the Community Court shall be binding on the Member States, the institutions of the Community and on individuals and corporate bodies. When in operation, the Court is expected to carry out its mandate independently of influence from the Member States and the other Community institutions. Although the emphasis on the binding nature of the decisions of the Community Court validates the supranational status of the Community and ECOWAS as revised, in practice the picture is not as vivid. ${ }^{12}$ Article 34(1) of the 1991 Protocol provides that "the protocol shall enter into force, provisionally, upon signature by the Head of State and Government of Member States, and, definitively, upon ratification by at least seven (7) signatory States in accordance with the constitutional regulations in force in each Member State." After the adoption of the Revised ECOWAS Treaty in 1993, no further action was taken until 1996 when seven Member States ratified the 1991 Protocol. Ten years later, in January 2001, the first seven judges of the Court were eventually sworn in.

\footnotetext{
${ }^{10}$ Articles 15 and 16 of the Revised ECOWAS Treaty respectively established a Court of Justice of the Community and Arbitration Tribunal of the Community. The status, composition, powers, procedure, and other issues concerning the Arbitration Tribunal are to be set out in a separate Protocol that is yet to be finalized.

${ }^{11}$ Article 15(2), Revised Treaty.

${ }^{12}$ See generally Alter et al., "A New International Human Rights Court for West Africa: The ECOWAS Community Court of Justice,"737-79. (Examining the redeployment of ECOWAS Community Court as an international human rights court from its original role to build common market).
} 
Despite the appointment of the full complement of staff, the Community Court was idle for a couple of years because the Member States did not institute any proceedings against each other. The first case was not instituted until 2003. The dispute related to the freedom of movement within the Community and provided a unique opportunity for the court to make a pronouncement on the Community protocol. In Olajide Afolabi v. Federal Republic of Nigeria,${ }^{13}$ the plaintiff, a Nigerian businessman, concluded arrangements for the purchase of goods and to take delivery of them in Republic of Benin. However, he could not complete the transaction because the border between Nigeria and Benin was unilaterally closed by Nigeria. His principal cause of action was that the closing of the Nigerian border with Benin by the Nigerian Ministry of Foreign Affairs not only denied him access to the neighbouring country and effectively prevented him from meeting his contractual obligation, but also was a violation of ECOWAS Community protocols relating to the freedom of movement of persons and goods. The Plaintiff brought the action pursuant to Article 9 (Competence of the Court) of the 1991 Protocol and Article 76 (Settlement of Disputes) of the Revised ECOWAS Treaty.

By a preliminary objection, the Nigerian government challenged the capacity of the plaintiff to institute the action on the basis that he had no direct access to the Community Court as the only plaintiff allowed under the 1991 Protocol is a Member State. The plaintiff responded that the provision empowering the Member States to sue on behalf of their citizens is not absolute. For if it were, the implication of the strict interpretation of the protocol is that a Member State could potentially be both the plaintiff and defendant

\footnotetext{
${ }^{13}$ See Olajide Afolabi v. Federal Republic of Nigeria, ECW/CCJ/APP/O1/03 (judgment of 27 April 2004), http://dev.ihrda.org/doc/ecw.ccj.jud.01.04/view/.
} 
in a suit. The plaintiff therefore urged the Court to purposively interpret the protocol to confer locus standi on him and avoid the absurdity that may ensue from a strict interpretation. The Community Court narrowed the only question for determination to: whether the Court has the jurisdiction to adjudicate on the suit. It rejected the arguments of the plaintiff and held that the provisions of Article 9 are clear and unambiguous. The Community Court's responsibility is to simply apply the laws and not purposively interpret them to seek a further objective not contemplated by the legislature. In other words, the only party with jurisdiction to initiate an action before the Court is a Member State, and it can do so on behalf of its nationals against another Member State.

Despite its negative outcome, Afolabi's case has been cited by some scholars as the primary regional basis for the successful agitation by ECOWAS judges, nongovernmental organizations, and Community officials for an expansion of the jurisdiction of the Court. ${ }^{14}$ Karen J. Alter, Laurence R. Helfer, and Jacqueline R. McAllister provide a detailed account of this process at the regional level. ${ }^{15}$ Following Afolabi's case, the Court officials printed and circulated copies of the ruling and the parties' legal arguments, while the judges drafted and circulated a proposal that showed the flaws of the court and called for the expansion of their jurisdiction. ${ }^{16}$ According to Alter et al, among other things, the judges publicized the need to provide access for private litigants in both economic and human rights cases:

\footnotetext{
${ }^{14}$ Alter et al., "A New International Human Rights Court for West Africa: The ECOWAS Community Court of Justice", 750.

${ }^{15}$ Ibid.

${ }^{16}$ Karen Alter, "The Global Spread of European Style International Courts," (2012) 35:1 West European Politics, 135-54, 149.
} 
The right of access to the Court is the keystone in the development of Community law. The promotion and protection of human rights and fundamental freedoms of Community Citizens cannot be ignored, if right of direct access to the Community Court of Justice is not guaranteed. A cardinal objective of ECOWAS is the formation of an economic union and a common market....[T] his scheme and the intended benefits cannot be realized, unless individuals, consumers, manufacturers and corporate bodies that are the prime movers in commercial transactions have direct access to the Court of Justice. ${ }^{17}$

ECOWAS Member States did not resist the move to expand the jurisdiction of the Court, and, encouraged by the lack of opposition, the stage was set for the ECOWAS Secretariat, non-governmental organizations, the judges, and staff to push the amendment ahead. ${ }^{18}$ Hence, " $[\mathrm{b}]$ arely nine months after the dismissal of the Afolabi case, the coordinated court reform campaign reached a successful conclusion" ${ }^{19}$ as ECOWAS Member States adopted the 2005 Supplementary Protocol. ${ }^{20}$

The 2005 Supplementary Protocol introduced significant changes to the personal and subject matter jurisdiction of the Court. With respect to subject matter, the jurisdiction of the Community Court now extends to the determination of cases of violation of human rights that occur in any Member State $;^{21}$ any matter provided for in an agreement where the parties provide that the disputes arising from the agreement shall be settled by the

\footnotetext{
${ }^{17}$ Alter et al., "A New International Human Rights Court for West Africa: The ECOWAS Community Court of Justice," 751, FN 90.

${ }^{18}$ Ibid., 752. The authors described the lobbying effort led by NGOs to Member State governments that were sympathetic to the call for the expansion of the Court's jurisdiction.

${ }^{19}$ Ibid., 753.

${ }^{20}$ See Supplementary Protocol A/SP.1/01/05 Amending the Preamble and Articles 1, 2, 9, and 30 of Protocol A/P.1.91 Relating to the Community Court of Justice and Article 4 Paragraph 1 of the English Version of the Said Protocol, http://www.courtecowas.org/site2012/pdf files/supplementary protocol.pdf.

${ }^{21}$ See generally Article 3 (revising Article 9 of the 1991 Supplementary Protocol). It may be noted that one of the Fundamental Principles of the Revised ECOWAS Treaty is "recognition, promotion and protection of human and peoples' rights in accordance with the provisions of the African Charter on Human and Peoples' Rights.” See. Article 4(g)
} 
Community Court; ${ }^{22}$ and, any national proceeding referred to it, but, there is no mandatory requirement that the national judges refer cases to the Community Court. The 2005 Supplementary Protocol also introduced a new provision on access to the Community Court. ${ }^{23}$ Access to Court is now open to individuals who seek relief for violation of their human rights. An application for relief on the basis of human rights violation shall not be anonymous, nor, be made while the same matter has been instituted before another international court. ${ }^{24}$ While Member States, the Council of Ministers, and the Commission remain primary litigants with respect to economic integration disputes, ${ }^{25}$ individuals and corporate bodies now equally enjoy access to the Court as plaintiffs "in relation to proceedings for the determination of an act or inaction of a Community official which violates the rights of the individuals or corporate bodies. ${ }^{26}$

According to Alter et al., the expansion of the jurisdiction of the Community Court introduced three features that distinguish it from other international human rights courts: direct access for private parties, ${ }^{27}$ the absence of ECOWAS specific human rights

\footnotetext{
${ }^{22}$ Article 9(6); Article 4(g).

${ }^{23}$ Article 4.

${ }^{24}$ Article 4(d) (revising Article 10 of the 1991 Supplementary Protocol).

${ }^{25}$ For arguments making the case for individuals as defendants, see Enyinna S. Nwauche, "The ECOWAS Community of Justice and the Horizontal Application of Human Rights" (2013) 13 AHRLJ, 30-54.

${ }^{26}$ Article 4 (revising Article 10 of the 1991 Supplementary Protocol).

${ }^{27}$ See Tidjani v. Nigeria, Case No. ECW/CCJ/APP/01/06 (28 July 28 2007). This is unlike the African Court on Human and Peoples' Rights at the continental level that provides direct access to litigants only if the concerned State has ratified the protocol establishing the Court and filed a separate optional declaration allowing the litigant to make such complaints. See Mia Swart, "Can Regional and Sub-Regional African Courts Strengthen the Rule of Law in Africa? Questions of Impact and Enforcement," Shielding Humanity, ed. Charles Jalloh and Olufemi Elias, (Leiden: Koninklijke Brill NV, 2015), 705-725, 707; ; International Federation for Human Rights, Practical Guide: The African Court on Human and peoples' Rights: Towards the African Court of Justice and Human Rights, April 2010, https://www.fidh.org/IMG/pdf/african court guide.pdf.
} 
standards, ${ }^{28}$ and non-exhaustion of domestic remedies. ${ }^{29}$ First, in extending direct access before the Community Court to nationals of the Member States, the Supplementary Protocol not only expands the category of persons that can sue before the Court but also circumvents a significant problem that the Court has faced since its establishment: that ECOWAS Member States do not sue one another.

The risk of making the Court redundant was high but for the intervention of the Supplementary Protocol. Granting private citizens "access to regional bodies is also an attractive way to demonstrate that regional institutions are concerned about citizens achieving the benefits promised by economic, development, and human rights international agreements. ${ }^{30}$ Importantly, the access to the court by individuals restricts the discretion of the ECOWAS Member States to decide which disputes should be litigated and minimizes governments' oversight with respect to the claims adjudicated before the Court. ${ }^{31}$ Further, granting direct access to individuals validates the legitimacy of the community's legal system by granting them a stake in the trajectory and shaping of the community law. ${ }^{32}$ The expansion of the jurisdiction of the Community Court in challenging the state-centric ontology of the 1991 Protocol has opened the floodgates of

\footnotetext{
${ }^{28}$ In Ugokwe v Nigeria, the ECOWAS Court noted, "the inclusion and recognition of the African Charter in Article 4 of the Treaty of the Community behoves on the Court by Article 19 of the Protocol to bring in the application of those rights catalogued in the African Charter." The Charter covers a broad range of civil and political and economic and social rights. ${ }^{28}$

${ }^{29}$ Alter et al., "A New International Human Rights Court for West Africa: The ECOWAS Community Court of Justice," 740; also see Solomon T. Ebobrah, "Critical Issues in the Human Rights Mandate of the ECOWAS Court of Justice" (2010) 54 Journal of African Law, [-].

${ }^{30}$ Adewale Banjo, "The ECOWAS Court and the Politics of Access to Justice in West Africa" (2007) 32:1 Africa Development, 69-87. (Examining the evolution of the Community Court, how the problems of lack of awareness by the Community citizens, non-patronage by the states, and inaccessibility to the Community citizens have become problems as well as how they are being resolved.)

${ }^{31}$ Karen Alter, The New Terrain of International Law: Courts, Politics, Rights, (Princeton University Press, 2014), 40.

${ }^{32}$ See Richard F. Oppong, "Integration through Law: An Examination of the Jurisprudence of Regional Economic Integration Judicial Bodies in Africa," 210
} 
litigation by individuals before the court. Parties adopt various innovative strategies to cloak their case as a violation of human rights in order to fall within the jurisdiction of the Court. ${ }^{33}$ The nature of the complaints filed before the Court extend to environmental, educational, and criminal violation of human rights. The Court has responded to these complaints by adopting a fairly strict pleading and high threshold of proof requirements. ${ }^{34}$ Second, the absence of a specific human rights standard or legislation in the Community has also been identified as a unique feature, as litigants can invoke a wide array of international human rights instruments that their countries are signatories to as the basis for their action before the Community Court. Third, with respect to the exhaustion of local remedies, the Court has been bold in carefully affirming the fact that citizens do not need to exhaust local remedies before seeking relief in the Community Court. In Ocean King Nigeria Limited v Republic of Senegal, Community Court affirmed that it had jurisdiction over human rights violations under Article 9(4), as amended by the Supplementary Protocol of 2005, and that the applicant was not obliged to exhaust local remedies in order to have access to the Court. ${ }^{35}$

While the expansion of the jurisdiction to the violation of human rights has kept the Court busy, disputes arising from economic cooperation or integration that relates to the interpretation of the Community Laws have not been adjudicated at all before the Court.

\footnotetext{
${ }^{33}$ See Henry Onoria, "Locus Standi of Individuals and Non State Entities before Regional Economic Integration Bodies in Africa" (2010) 18 African Journal of International \& Comparative Law, 143-69.

${ }^{34}$ See Center for Democracy and Development and Center for Defense of Human Rights and Democracy $v$ Mamadou Tandja and the Republic of Niger, 2011 CCJELR 105.

${ }^{35}$ See Ocean King Nigeria Limited v. Republic of Senegal, Suit No. ECW/CCJ/APP/05/08; Judgment No. $\mathrm{ECW} / \mathrm{CCJ} / \mathrm{JUD} / 07 / 11$. For an example of a situation where the ECCJ declined jurisdiction to avoid abuse of Court as reliefs sought in the previous case and granted are similar to the one before it, see, Sa'Adatu Umar v Federal Republic of Nigeria; Suit No. ECW/CCJ/APP/12/11; Judgment No. ECW/CCJ/JUD/17/12. For academic discussion the exhaustion of domestic remedy, see A. O. Enabulele, "Sailing Against the Tide: Exhaustion of Domestic Remedies and the ECOWAS Community Court of Justice" (2012) 56:2 Journal of African Law 268-95; Andreas von Staden, "Subsidiarity, Exhaustion of Domestic Remedies, and the Margin of Appreciation in the Human Rights Jurisprudence of African Sub-regional Courts" (2016) 20:8 International Journal of Human Rights, 1113-31.
} 
In response to the question, why did the ECOWAS Member States allow direct access for human rights complaints but not for suits alleging violations of ECOWAS economic rules, Alter et al. identified five explanations that they gleaned from the stakeholders: to wit, judges, the secretariat officials, and civil society groups that agitated for the expansion of the Court's jurisdiction acted in good faith; all stakeholders were united in ensuring that the Court functioned and that the judges were not idle; human rights activists lobbied for the introduction of human rights specifically as well as particular institutional features; and, the Protocol would enter into force provisionally-this provided some confidence that Member States retained some control. ${ }^{36}$

However, without discountenancing the regional agitation from below that followed Afolabi's case, it is reductionist to suggest that these are the sole reasons for the expansion. The diffusion of contemporaneous developments at the international level that conceptualize the integration of human rights, good governance, and democracy as essential to free market fundamentalism and economic development are as relevant to the expansion. In addition, the hybridity generated as a result of the theoretical overlap between developmental state and neoliberalism and regional social conflicts, provide an additional lever through which I examine the Community Court's 1991 and 2005 Protocols as embedded and being shaped by the wider context of socio-political developments in the ECOWAS Community and the international economy.

\footnotetext{
${ }^{36}$ The authors note that the "[g]overnments may therefore have believed that the Court's human rights jurisdiction would be relatively easy to undo if the Court later behaved in ways that encroached on national sovereignty." Alter et al., "A New International Human Rights Court for West Africa: The ECOWAS Community Court of Justice,", 756-58.
} 


\subsection{The Socio-Political Context for the Expansion of the Community Court}

According to Karen Alter, unlike "old-style international courts that lack compulsory jurisdiction so that cases can only proceed with the consent of the defendant-state, newstyle [International courts] have compulsory jurisdiction, and they allow non-state actors-international commissions, prosecutors, institutional actors, and private litigants - to initiate litigation." ${ }^{37}$ Since its establishment, the Community Court has evolved, through the amendments to its subject matter and personal jurisdiction, from a strict economic integration-enhancing Court to one with jurisdiction over human rights violations in Member States. Developments at the international level, particularly with respect to the good governance proposals as exemplified by its core elementsdemocracy, the rule of law, and human rights - provide an important aspect of the broader socio-political contexts that shaped the expansion of the ECOWAS Court. ${ }^{38}$ The expansion of the jurisdiction of the Community Court to human rights should not therefore be discussed outside the context of this broader international development discourse that links economic growth to the advancement of human rights, good governance, and democratization. ${ }^{39}$ As demonstrated in chapter 5, these ideas were aggressively promoted by the World Bank and the International Monetary Fund as important components for measuring the progress of developing countries.

\footnotetext{
${ }^{37}$ Alter, The New Terrain of International Law, 28.

${ }^{38}$ See Martin Hopner and Armin Schafer, "Embeddedness and Regional Integration: Waiting for Polanyi in a Hayekian Setting" (2012) 66 International Organization, 429-55.

${ }^{39}$ See Hans-Otto Sano, "Development and Human Rights: The Necessary, but Partial Integration of Human Rights and Development” (2000) 22 Human Rights Quarterly, 734-52.
} 
In the context of international development discourse, scholars have been critical of these proposals as new technologies of governance by which the international institutions continued their domination of the developing countries by ensuring a construction of the narrative of the "developing" through the lens of the Western societies. ${ }^{40}$ However, beyond the national contexts, these proposals have been diffused to the regional economic communities as well and shaped their implementation. In addition to influencing the amendments to the Community Court's protocol, these factors shape the trajectory of the cases that are instituted before the Court as regional economic cooperation institutions are embedded in the social relations of the Community Members, the rule of law, and the protection of human rights are equally intertwined in the interaction. As Karen J. Alter and Liesbet Hoogie argue, "careful process tracing of particular dispute settlement instances is beginning to suggest some systematic transmission belts along which global norms on democracy, human rights, or the 'Washington Consensus' may be diffused into regional regimes. ${ }^{, 41}$ One of the ways that the influence of the good governance narratives were diffused in the regional context was through regional projects sponsored by international institutions that are aimed at promoting them. ${ }^{42}$ In the good governance agenda, a civil society free of governmental controls and an independent judiciary were essential, even if they were often rejected in whole or in part by the receiving states. ${ }^{43}$ The globalization of the good governance

\footnotetext{
${ }^{40}$ See André Mbata Mangu, "The African Union and the Promotion of Democracy and Good Political Governance under the African Peer-Review Mechanism: 10 Years On" (2014) 6:1 African Review, 59-72.

${ }^{41}$ See Karen J. Alter and Liesbet Hoogie, "Regional Dispute Settlement" in Oxford Handbook of Comparative Regionalism, ed. Tanja A. Börzel and Thomas Risse (Oxford: Oxford University Press, 2016) $538-58,550$.

${ }^{42}$ See for example, The African-EU Partnership Project, which has its priority areas as "Democracy, Good Governance and Human Rights," http://www.africa-eu-partnership.org/en/priority-areas/democracy-goodgovernance-and-human-rights.

${ }^{43}$ Gathii, Retelling Good Governance Narratives, 1033.
} 
proposals and the human rights in particular was aided by the fact that the ECOWAS region was engrained in various social conflicts with significant violation of human rights. While many ECOWAS Member States symbolically became democratic states, most remained a one-party state, and the majority of them carried on the strictures of military dictatorship under the guise of democratic governance. ${ }^{44}$ The implication was that many of their practices were rife with human rights violations, non-conduct of elections, or in the limited situations where elections were conducted, they were stagemanaged by the ruling party.

Regionally, social conflict in the ECOWAS region has not gone without complaints of violations of human rights. ${ }^{45}$ The incorporation of human rights violation in the Community Court also reflects its embeddedness in the social and political contexts of ECOWAS Member States. The historical and socio-political rationale lies in the human rights violation practices of Member States; the rise of civil society and nongovernmental organizations as resistance actors in the domestic contexts; as well as the need for alternative human rights dispute settlement forum outside of the national courts that may be subjected to influence by the executive. The rise of social conflicts within ECOWAS Member States is an important, but often ignored, aspect of the rise of human rights litigation in West Africa. ${ }^{46}$ In other situations, human rights violations were as a

\footnotetext{
${ }^{44}$ See Pacifique Manirakiza, "Insecurity Implications of Unconstitutional Changes of Government in Africa: From Military to Constitutional Coups," (2016) 17:2 Journal of Military and Strategic Studies, 86106.

${ }^{45}$ M. Granovetter, "Economic Action and Social Structure: The Problem of Embeddedness" (1985) 19 American Journal of Sociology 481-510; Clair Gammage, "Protecting Human Rights in the Context of Free Trade? The Case of the SADC Group Economic Partnership Agreement" (2014) 20:6 European Law Journal, 779-92.

${ }^{46}$ Jeremy Levitt, "Conflict Prevention, Management, and Resolution: Africa—Regional Strategies for the Prevention of Displacement and Protection of Displaced Persons: The Cases of the OAU, ECOWAS,
} 
result of ECOWAS peacekeeping operations in regional Member States that are engulfed by internal conflicts.

The point of the foregoing is that rather than an organic evolution, the expansion of the ECOWAS Community Court to human rights and the subsequent uses of the Court based on the cases that are instituted before it demonstrate the embeddedness of the Community Court in a complex and simultaneous interaction of ideologies, social relations, social conflict and wider socio-political contexts at the international and national levels. In part, these complex socio-political interactions underlie the implementation conundrum that exists today as a result of the lack of disputes by ECOWAS Member States in relation to regional economic integration. Below, I deepen the analysis of the socio-political contexts.

\subsection{Hybridity: Developmental Regionalism and Neoliberal Regionalism in the Community Court}

One of the important implications that the Afolabi case brought to the fore is the ideological overlap between neoliberalism and the developmental state. ECOWAS has "made little progress toward its professed goal of regional economic integration... and member states have yet to challenge barriers to intraregional trade before the ECOWAS Court." ${ }^{47}$ While neoliberalism provides the underpinning ideology for the Revised ECOWAS Treaty and the 2005 Protocol, and requires a limited role for the state, the

SADC, and IGAD" (2001) 20:1 Refugee Survey Quarterly, 156-90; Human Rights Watch, "The Regional Crisis and Human Rights Abuses in West Africa" A Briefing Paper to the U.N. Security Council, 20 June 2003, https://www.hrw.org/news/2003/06/20/regional-crisis-and-human-rights-abuses-west-africa; N. Annan, "Violent Conflicts and Civil Strife in West Africa: Causes, Challenges and Prospects" (2014) 3:1 Stability: International Journal of Security and Development.

${ }^{47}$ Alter et al., "A New International Human Rights Court for West Africa: The ECOWAS Community Court of Justice" (2013) 107:737 American Journal of International Law , 737-79, 738. 
developmental state underpinned the Establishing Treaty and the 1991 Protocol that has the state as the sole actor. Despite the neoliberal emphasis on private sector-led economy and new regionalism insight on the role of multiple actors that underpin the Revised ECOWAS Treaty, ECOWAS Member States are the only litigants with respect to disputes arising from regional economic integration laws in the Community. The overlap of neoliberal and developmental state ideologies is what I describe as hybridity. The premise here is that developmental state regionalism was never completely off the table. The neoliberal project delegitimizes the state as the primary actor, reducing its role to that of a passive observer. ${ }^{48}$ Neoliberalism and human rights share a commitment to the prime significance of the individual. That both controversially share "antipathy towards, or at least suspicion of, the state, and especially the nation-state, also seems plain, since both reject its moral credentials." ${ }^{49}$

The hybridity between developmental and neoliberal regionalism paradigms in ECOWAS sheds light on one of the cardinal areas that shape the implementation of the regional economic integration component of the Community Court. Existing analyses of the Community Court do not interpret this intricate overlap as a form of hybridity; yet, it offers an important illumination to what may otherwise appear as contradictory. The fledgling or weak developmental regionalism continues to be embraced in the social relations of ECOWAS Member States even as neoliberalism was being institutionalized.

\footnotetext{
${ }^{48}$ See Björn Beckman, "The Liberation of Civil Society: Neo-Liberal Ideology and Political Theory" (1993) 58 Review of African Political Economy, 20-33

${ }^{49}$ Samuel Moyn, "A Powerless Companion: Human Rights in the Age of Neoliberalism" (2014) 77:4 Law and Contemporary Problems, 147-169, 156.
} 
The hybridity that emerges as a result of the overlap is akin to what Law and Development scholars describe as the "new developmental state phenomenon." 50 The new developmental state phenomenon in the globalized world or in the twenty-first century is different from the "developmental state" of the 1970s. In this new era, "neither the state nor the private sector alone is capable of developing optimal developmental trajectories." ${ }^{51}$ Some of the features of the "new developmental state phenomenon" described by David Trubek as a moving target include a primary resilience on the private sector as well as "the acceptance of a major role for the state in steering investment, coordinating projects and providing information especially in projects with multiple inputs." 52 Indeed, the United Nations Conference and Trade and Development (UNCTAD) 2013 Economic Development in Africa report alludes to the return of a "developmental regionalism paradigm" that leverages on public and private sector partnership. $^{53}$

The contention is that by not devolving any role to individuals or the private sector with respect to regional economic disputes, the ECOWAS Member States have not completely let go of the vestiges of the developmental state ideology. Given the overlap with neoliberalism, the form of developmental state practice during this era requires a more

\footnotetext{
${ }^{50}$ David M. Trubek, Helena Alviar Garcia, Diogo R. Coutinho, and Alvaro Santos (eds), Law and the New Developmental State: The Brazilian Experience in Latin American Context, (Cambridge: Cambridge University Press, 2013)

${ }^{51}$ David M. Trubek, "Law, State, and the New Developmentalism: An Introduction" in Law and the New Developmental State: The Brazilian Experience in Latin American Context, ed. by David M. Trubek, Helena Alviar Garcia, Diogo R. Coutinho, and Alvaro Santos (Cambridge: Cambridge University Press, 2013), 3-27, 9 .

${ }^{52}$ David M. Trubek, "Developmental State and the Legal Order: Towards a New Political Economy of Development and Law," paper delivered at the Conference on Social Science in the Age of Globalization, National Institute for Advanced Study on Social Science, Fuan University, Shanghai, December 2008, 134,11 .

${ }^{53}$ UNCTAD, Economic Development in Africa: Intra-African Trade, Unlocking Private Sector Dynamism, United Nations, 2013.
} 
empirical study to understand its other features. Interestingly, the Final Report of the Committee of Eminent Persons recommended that for ECOWAS "to be meaningful and effective, it must shift from its exclusive focus on government to government, to involving people, NGOSs and the private sector." ${ }^{54}$ Specifically, the CEP stated that where "a Community citizen alleges a breach or denial of a right conferred on him by a Community legislation, a Treaty provision or a protocol, it should be possible for him to seek redress in the national court or the Community Court of Justice.... This would also require amendment to Article 9 of the Protocol of the Community Court of Justice." However, the Member States did not take the point on board at the initial adoption of the treaty. Instead, they retained the power to make the decisions to go to the Community Court in the Authority. ${ }^{56}$ This underlying dissonance between the Committee's report, the role of the Member States in relation to litigation before the Community Court, and their designated representatives who are to implement the treaty is representative of the hybridity in the overlap between developmental and neoliberal regionalisms. The hybridity is symbolic of the broader social interactions and distrust among the Community Members and points to the fact that, despite the neoliberal underpinning of the new era, the Community Court and its operations remain embedded in the sociopolitical relations of the Member States.

To devolve the capacity to sue in relation to economic integration disputes to nationals of ECOWAS Member States has implications for their economic and political sovereignty as well as the supranational status of ECOWAS. This pattern is symbolic of the

\footnotetext{
${ }^{54}$ Final Report of the Committee of Eminent Persons, June 9, 1992, 5.

${ }^{55}$ Ibid., 20-21.

${ }^{56}$ Ibid.
} 
continuation of the attitude of the Member States under the ECOWAS Establishing Treaty. Retaining the power to sue, therefore, reinforces the economic and political sovereignty of the Member States to make decisions that impact on their national economy. It also foretells that the Member States continue to prioritize their national economy over regional aspirations. As no other individual has the right to sue on regional economic disputes, the Community Court would never be presented with the opportunity to make decisions that impact the national economic decisions of the Member States.

Although it was not intentional, the expansion to human rights has sustained this hybridity in that it has kept the Community Court busy and prevented a situation where it would have been redundant due to lack of regional economic integration disputes to adjudicate upon. Private citizens and non-governmental organizations have initiated the majority of cases that have been adjudicated upon by the Court. As a former president of the Community Court notes, "since the 2005 expansion of the court's jurisdiction to include cases of human rights violations, the number of cases has increased from about two to 227 , most of them for the violation of human rights. ${ }^{.57}$ Human rights cases have "become the most prominent aspect of the work of the Community Court creating an impression that its primary role is to monitor compliance with the international human rights commitments of the member states." ${ }^{58}$ Indeed, the category of cases initiated before the court has extended beyond human rights cases to political cases involving

\footnotetext{
${ }^{57}$ See ECOWAS Community Court of Justice Press Release, "ECOWAS Court Calls for Expansion of its Facilities to Enable it to Cope with Increased Responsibility," 26 October 2015, http://www.courtecowas.org/site2012/index.php?option $=$ com content\&view=article\&id=275:ecowascourt-calls-for-expansion-of-its-facilities-to-enable-it-cope-with-increased-responsibility\&catid=14:pressrelease \&Itemid $=36$.

${ }^{58}$ See Solomon Ebobrah, "The Role of the ECOWAS Community Court of Justice in the Integration of West Africa: Small Strides in the Wrong Direction?," 17.
} 
election in Member States, good governance, environmental issues, and education. ${ }^{59}$ In this hybrid form, developmental regionalism does not contradict neoliberal regionalism.

\subsection{Navigating the Implementation Conundrum in the Community Court}

Akin to the legal formalist critique of the implementation conundrum under the ECOWAS Establishing Treaty, one of the sustained critiques of the ECOWAS Community Court has been the gap in the enforcement, compliance with, or implementation of its decisions. By not giving effect to its decisions, an implementation conundrum emerges, which puts into question the effectiveness or usefulness of the decisions of the Court. ${ }^{60}$ Much of the analysis of compliance with the Community Court's decision implies an instrumental view of the law. Indeed, while some of the decisions have been complied with, others have not. More empirical research would be required to analyze the statistics.

However, navigating the effectiveness of the Community Court through the lens of traditional compliance is limiting, like legal formalism. It is limiting in the sense that it does not capture other broader socio-political context and motivations that influence the cases instituted before the Court or other ways that the decisions of the Court may have influenced socio-cultural paradigms in the Member States, other than through the

\footnotetext{
${ }^{59}$ See Horace S. Adjolohoun, "AJIL Symposium: Can the ECOWAS Court Revive Regionalism through Human Rights?," 4 February 2014, http://opiniojuris.org/2014/02/04/ajil-symposium-can-ecowas-courtrevive-regionalism-human-rights/.

${ }^{60}$ See ECOWAS Parliament Press Release, "Parliamentarians Decry Non-Enforcement of the Community Court Judgments," (20 May 2014, http://www.parl.ecowas.int/documents/session mai 2014/pr3.pdf.
} 
traditional prism of compliance. ${ }^{61}$ For example, compliance-centric analysis will not account for important ways that the cases before the Court might add value to struggles that have been championed by social and human rights activists in their countries or as a way to mount pressure on Member States. Although the nature of the impact of these decisions do not conform to mainstream understandings of compliance or enforcement of judgments by institutions, their social impact must nonetheless be aggregated, as it provides important new and broader insights into the activities of the Community Court that reinforce the theoretical accounts adopted by this thesis. The underlying thinking is that ECOWAS and the role or focus of its institutions are being transformed as the political economies of Member States undergo transitions in concert with the balance between and sequence of political, social, and economic liberalizations. ${ }^{62}$ As Solomon Ebobrah rightly notes, "the role judicial organs of regional economic communities (RECs) play in the early stages of regional integration is fluid and is determined more by socio-political challenges within the integrating geographical area than by objectives and functions set out in founding treaties. As such their impact on integration should be measured, taking such socio-political challenges into account." 63

\footnotetext{
${ }^{61}$ See Okechukwu C. Iheduru, "Civil Society and Regional Integration in West Africa: Partners, Legitimizers, and Counter-hegemonic Actors" in Civil Society and World Regions: How Citizens Are Reshaping Regional Governance in Times of Crisis, ed. Lorenzo Fioramonti (Toronto: Lexington Books, 2014), 137-60, 138.

${ }^{62}$ See Shaw et al., "Introduction and Overview: The Study of New Regionalism(s) at the Start of the Second Debate of the Twenty-First Century,"1-30, 14.

${ }^{63}$ See, Solomon T. Ebobrah, "The Role of the ECOWAS Community Court of Justice in the integration of West Africa: Small Strides in the wrong direction?” iCourts Working Paper Series, No. 27, June 2015, Also see, Kofi Oteng Kufuor, "AJIL Symposium: Regional Courts, Regionalism, Critical Junctures and Economic Integration in Africa", Opinion Juris, February 3, 2014, Online: http://opiniojuris.org/2014/02/03/ajil-symposium-regional-courts-regionalism-critical-junctures-economicintegration-africa/b; also see, Solomon T. Ebobrah, "AJIL Symposium: Comment on "A new International Human Rights Court for West Africa", February 3, 2014, Online: http://opiniojuris.org/2014/02/03/ajilsymposium/
} 
Understanding the increased normative authority of the Court over matters such as human rights, and other non-economic matters, requires a different mode of analysis other than compliance-centric approaches that draw a line from the decision to its implementation. The claim here is not that such an exercise is futile; rather, it would require a reconceptualization or broadening of the measurement of compliance to account for the motivations of the litigants beyond winning the cases. ${ }^{64}$

I continue the analysis by focusing on some of the important cases from the Community Court. In discussing these cases, the aim is not to examine the substantive effectiveness of the Court or its performance; rather, they are analyzed to demonstrate that the broad range of cases that have been instituted before the Community Court strengthens the claim in this thesis that the Community Court is embedded in the socio-political relations of the Member States and the international community. The cases also demonstrate the ongoing tension and complexity of speaking of "compliance" with the Community Court decisions in legal formalist context. In this regard, ECOWAS Community Court has experienced pushback either in Court or by the Member States simply ignoring the Court's order in lieu of protecting their sovereignty. As indicated above, understanding the implementation conundrum would require a reconceptualization of the concept of compliance or effectiveness to accommodate the embedded socio-political and mostly informal motivations of the litigants before the Court. This exercise is outside the purview of this thesis.

\footnotetext{
${ }^{64}$ For an example of this type of analysis in relation to human rights in international African Courts, see, Obiora Chinedu Okafor, The African Human Rights System, Activist Forces and International Institutions, (Cambridge University Press, 2007)
} 


\subsubsection{Human Rights: Abolition of Slavery}

The "historic" case of Hadijatou Mani Koraou v The Republic of Niger ${ }^{65}$ demonstrates how the Community Court is used to challenge embedded socio-cultural practices of slavery in Niger. The practice of slavery that is the subject of complaint in this case has social acceptance and implicit legitimacy as transactions leading to the sale are conducted in contractual form evidenced "by transfer and certificates of liberation, which were officiated and witnessed by several people, including village chiefs." 66 The applicant alleged a violation of her fundamental human rights by one El Hadj Souleymane Naroua pursuant to Articles 9(4) and 10(d) of the 2005 Protocol. Before the Community Court, she sought a declaration that the Republic of Niger violated the African Charter on Human and People's Rights; an order that Niger authorities adopt legislation that effectively protects women against discriminatory customs relating to marriage and divorce; a revision of its legislation to allow Courts and Tribunals to effectively protect victims of slavery; and grant the victim monetary remedy as the victim of slavery. The Republic of Niger's effort to frustrate the proceeding before its national courts failed. ${ }^{67}$ The defendant objected to the admissibility of the action before the Community Court on the ground of lack of exhaustion of domestic remedies contending that the case is pending before the national Court of the Republic of Niger. The defendant urged the Community Court to purposively interpret the case to fill what they consider a gap in the non-exhaustion of domestic remedies.

\footnotetext{
${ }^{65}$ Hadijatou's case.

${ }^{66}$ Helen Duffy, "Hadijatou Mani Koroua [sic] v. Niger: Slavery Unveiled by the ECOWAS Court,"154.

${ }^{67}$ For the summary of these proceedings, see, Hadijatou's case, https://www.unodc.org/res/cld/case-law doc/traffickingpersonscrimetype/ner/2008/h m v republic of niger html/Hadijatou Mani v. Republic of Niger Community Court of Justice Unofficial English translation.pdf.
} 
The Community Court held that the wahiya or sadaka ${ }^{68}$ practice under which the plaintiff was sold and married puts her in a disadvantageous situation and excluded her from the benefits of the equal dignity recognized to all citizens. The Community Court noted that the discrimination is not attributable to the Republic of Niger, although the latter did not sufficiently protect the applicant's right against the practice of slavery. Based on the physical, psychological, and moral harm suffered by the applicant, the Court awarded an all-inclusive compensation of $10,000,000 \mathrm{CFA}$, equivalent of US\$20,000. ${ }^{69}$ The cautious remedial option that the judges adopted in this case elicited full compliance by Niger Republic. $^{70}$ According to Helen Duffy, the fundamental significance of the case "lies in the vindication of the victim's rights and its potential, as yet uncertain, to contribute to the effective eradication of the abomination of slavery in West Africa." ${ }^{71}$ To further underline the importance of the Court's decision and its normative impact, in Niger, prosecutions for slavery are not pursued in practice. ${ }^{72}$ Hadijatou's case highlights "the

\footnotetext{
${ }^{68}$ It "consists of acquiring a young girl, generally a slave, to work as a servant as well as a concubine. The slave woman who is bought under these conditions is called "Sadaka" or fifth wife, i.e., a wife who is not one of the legally married ones, the number of which cannot exceed four (4), according to Islam's recommendations.... In general the 'Sadaka' does housework and is at the 'master's service.' He can, at any time, day or night, have sexual relations with her." Hadijatou's Case, ECCJ, paragraphs 9 and 10.

${ }^{69}$ See generally Jean Allain, "Hadijatou Mani Koraou v. Republic of Niger. Judgment No. ECW/CCJ/JUD/06/08” (2009) 103:2 American Journal of International Law, 311-17.

70 "Among the press reports referring to the case as historic, see "Former Slave Wins Historic Case against Niger Government," Telegraph, 28 October 2008; "Free at Last: Female Slave who Dared to Take Niger to Court," Times, 28 October 2008; "Court Rules Niger Failed by Allowing Girl's Slavery," New York Times, 27 October 2008; and "Une-cour-regionale- africaine-condamne-le-niger-pour-esclavage," Le Monde, 27 October 2008. In Kampmark, "A little Case of Slavery: Niger and Hadijatou Mani," Hadijatou's role is compared to Rosa Park's refusal to move seats on a segregated bus in the US, http://www.factsandarts.com/articles/a-little-case-of-slavery-niger-and-hadijatou-mani in Helen Duffy, "Hadijatou Mani Koroua [sic] v. Niger: Slavery Unveiled by the ECOWAS Court," (2009) 9:1 Human Rights Law Review, 151-70, 151-52.

${ }^{71}$ Helen Duffy, "Hadijatou Mani Koroua [sic] v. Niger: Slavery Unveiled by the ECOWAS Court", 152.

72 "By the time of the ECOWAS Court's judgment there had been only one prosecution for slavery, in which the penalty was reduced on appeal to one year's imprisonment....[C]ivil and customary courts continue to ignore these provisions and to apply customary laws that condone and regulate slavery," Helen Duffy, "Hadijatou Mani Koroua [sic] v. Niger: Slavery Unveiled by the ECOWAS Court", 155.
} 
promise of the ECOWAS Court as a mechanism to render speedy, effective and binding justice for violations of human rights in the region" ${ }^{73}$ that otherwise face long trial periods in the national legal system.

In terms of its socio-political influence, "the litigation process itself, even prior to judgment, had already made a significant contribution to exposing the existence of slavery... undoing the conspiracy of silence that has surrounded it to date" 74 and initiating broader conversation around the issue in new and meaningful ways. Second, as a catalyst for systemic legislative reforms, the government of the Republic of Niger committed to the judgment and acknowledged that it is binding on the country. Third, inherent in the high-profile nature of this case and the international attention it garnered is that the Republic of Niger and by extension other ECOWAS Member States were put on notice of the potential to be named and shamed where matters of human rights cases adjudicated by the Community Court are concerned. ${ }^{75}$ Naming and shaming is an important instrument of choice harnessed by many international organizations to improve human rights practices of states. ${ }^{76}$

\footnotetext{
${ }^{73}{ }^{73}$ Helen Duffy, "Hadijatou Mani Koroua [sic] v. Niger: Slavery Unveiled by the ECOWAS Court,” 169. ${ }^{74}$ Ibid., p. 170.

${ }^{75}$ Hadijatou has been honoured for her courage in various contexts, including being awarded the US State Department's International Woman of Courage award 2009. The then US Secretary of State Hilary Clinton said of Hadijatou and her case:

Hadijatou is such an inspiring person. Enslaved by being sold at a very young age, she never gave up on herself or on her deep reservoir of human dignity. When she finally escaped from slavery, she didn't forget those who were still enslaved. For her inspiring courage in successfully challenging an entrenched system of caste-based slavery, and securing a legal precedent that will help countless others seek freedom and justice, we honour and salute her.

See Woyingi Blogger, "African Women's Lives: Contemporary Slavery in Africa, Slavery in Niger: Hadijatou Mani Koraou," 3 April 2011, https://woyingi.wordpress.com/2011/04/03/african-womens-liveshadijatou-mani-koraou/.

${ }^{76}$ See James Meernik et al., "The Impact of Human Rights Organizations on Naming and Shaming Campaigns" (2012) 56(2) Journal of Conflict Resolution, 233-56. The authors note that "United Nationsaffiliated organizations...target some nations for particular attention and condemnation in the hope that
} 


\subsubsection{Right to Education}

Another high-profile case that demonstrates the socio-political influence on the Community Court and that it is embedded in the social relations of its Member States relates to the right to education in Nigeria: Registered Trustees of the Socio-Economic Rights and Accountability Project (SERAP) v Federal Republic of Nigeria \& Universal Basic Education Commission (UBEC) ${ }^{77}$ SERAP alleged that the federal government of Nigeria violated the right to quality education, the right to dignity, the right of the Nigerian peoples to their wealth and natural resources as well as the right to economic and social development of Nigerians. ${ }^{78}$ SERAP's suit followed a petition sent by SERAP to the Independent Corrupt Practices and Other Related Offences Commission (ICPC), which led to the discovery by the ICPC of massive corruption and mismanagement of the UBEC funds. The investigation "resulted in the recovery of stolen N3.4 billion, meant to improve the quality of education and access to education of every Nigerian child. The organisation used the findings of the ICPC as the basis for its suit before the ECOWAS Court."79

\footnotetext{
through such publicity these governments will be pressured into changing their abusive practices." See James Meernik et al., "The Impact of Human Rights Organizations on Naming and Shaming Campaigns," 233-34.

${ }^{77}$ Registered Trustees of the Socio-Economic Rights and Accountability Project (SERAP) v Federal Republic of Nigeria \& Universal Basic Education Commission, Suit No: ECW/CCJ/APP/08/08.

${ }^{78}$ SERAP invoked the provisions of Articles 1, 2, 17, 21, and 22 of the ACHPR.

${ }^{79}$ See Child Rights International Network, "ECOWAS: Landmark Court Decision on Right to Education," 23 November 2009, https://www.crin.org/en/library/news-archive/ecowas-landmark-court-decision-righteducation.
} 
In what appears a ploy to delay proceedings, the Nigerian government challenged the jurisdiction of the Court to entertain the suit, contending that the Compulsory and Basic Education Act of 2004 and the Child's Right Act are domestic Laws of Nigeria and "not subject to the jurisdiction of the Court because it is not a treaty, convention or protocol of ECOWAS. ${ }^{, 80}$ In particular, responding to the substantive case, the Nigerian government argued that pursuant to Section 18 (1-3) of Chapter II of the 1999 Constitution, educational objective is not justiciable and cannot be determined by the Court. The Community Court therefore had to determine whether the right to education is justiciable and can be litigated before it. On the one hand, the Nigerian government argued that the principles of state policy enshrined in Chapter II of the Constitution "represent ideals which the Federal Government ought to strive to achieve and do not confer any positive rights on any citizen, ${ }^{, 81}$ the government has absolute powers over educational matters and pursuant to Section 6(6)(c) of the Constitution, the Federal High Court of Nigeria is seized of the exclusive jurisdiction over such matters. On the other hand, SERAP contends that the Nigerian government's argument is misconceived as the Constitution contains norms that are internationally recognized as enforceable social and economic rights. In particular, SERAP relied on the International Covenant on Economic, Social and Cultural Rights and Article 17 of the African Charter on Human and Peoples' Rights which is independent of the right to education captured under the directive principles of state policy of the Nigerian constitution. First, the Community Court noted that the provisions of Chapter II of the Nigerian constitution are not justiciable before it. Assuming they were justiciable, the Court noted that it fell exclusively under the

${ }^{80}$ Registered Trustees of the Socio-Economic Rights and Accountability Project (SERAP) v Federal Republic of Nigeria \& Universal Basic Education Commission, 2.

${ }^{81}$ Ibid., 7. 
domestic jurisdiction of the Federal High Court of Nigeria. Speaking broadly on the position of the law where an ECOWAS Member State is a signatory to international agreements subsequently re-enacted in its laws, the Court noted that

[i]t is essential to note that most human rights provisions are contained in domestic legislation as well as international human rights instruments. Some of the fundamental human rights, such as the right to life, have been elevated to the status of "Ius Cogens", peremptory norms of international law from which no derogation is permitted. Hence, the existence of a right in one jurisdiction does not automatically oust its enforcement in the other." 82

Based on the foregoing, the Court noted that Article 17 of the African Charter on Human and Peoples' Rights on the right to education is enforceable and justiciable before it. Speaking of the importance of the case, Femi Falana, a senior advocate of Nigeria, said,

[t]his is the first time an international court has recognized citizens' legal right to education, and sends a clear message to ECOWAS member states, including Nigeria and indeed all African governments, that the denial of this human right to millions of African citizens will not be tolerated. ${ }^{83}$

Like the Hadijatou case, SERAP v. Federal of Nigeria was also a groundbreaking case as it held that all Nigerians are entitled to education as a legal and a human right contrary to the contention of the Nigerian government that the right as enshrined in the Constitution is a mere directive policy of the Federal Government and not a legal entitlement of the citizens. It was also the first time that the ECCJ or any other sub-regional human rights court would consider corruption as a violation of human rights. The Community Court also stated that while steps should be taken to recover funds and/or prosecute the suspects, the Nigerian government should provide the funds necessary to cover the

\footnotetext{
${ }^{82}$ Ibid., 9.

${ }^{83}$ Speaking further, Falana said, "We commend the ECOWAS Court for its ground-breaking ruling, which has permanently re-defined human rights jurisprudence in Africa. The ECOWAS Court has consistently demonstrated courage and industry in the discharge of its vital role in putting an end to violation of all human rights and impunity of perpetrators in the sub-region. We also acknowledge the important contribution of Dr. Kolawole Olaniyan of Amnesty International in London, to the case." See SERAP, "ECOWAS Court to FG: Nigerians Have a Legal Right to Education," http://serap-nigeria.org/ecowascourt-to-fg-nigerians-have-a-legal-right-to-education/.
} 
shortfall in order to avoid denying any of its people the right to education. ${ }^{84}$ The declaration of the Court however fell short of an order directing Nigeria to allocate the required funds. This dovetails the remedial caution that was exercised by the Court in the Hadijatou case. The implication of this is that the Court strategically avoids a backlash from Nigeria while it simultaneously encourages compliance with its decision.

\subsection{Conclusion}

The aim in this chapter has been to examine how the expansion of the jurisdiction of the Community Court from one primarily created for the interpretation and application of regional community laws to human rights reflects the fact that the Revised ECOWAS Treaty, Protocols, and its institutions created thereunder are embedded in the social and political context of the Community and the international society as a whole.

The ECOWAS Community Court was created as part of the wave of globalization of institutions, and in particular, judicial institutions in international economic law generally. These new Courts were conceptualized as supranational orders that would have binding power that pierces the economic, social, and political fabric of their Member

\footnotetext{
${ }^{84}$ According to a former president of the Nigerian Bar Association, J. B. Daudu, speaking of the groundbreaking nature of the ECOWAS Court judgment:

I doff my hat to Femi Falana and SERAP for their timely intervention in the Education Sector of this Country. It is the best Christmas present ever presented to Nigerians. The NBA believes in the use of Public Interest Litigation to compel Government authorities' compliance with constitutional and statutory provisions and duties. There can be no other way in a democratic society to ensure compliance with statutory directives that the resort to constitutional measures of redress. That is why Government must always respect the decisions of peaceful democratic institutions like our Courts when it is handed down. The alternative to disobedience is to encourage people to contemplate extra-judicial measures for the purpose of seeking redress. We urge Government to forthwith set up the machinery to obey the ECOWAS Court judgment and implement the terms of that judgment to the letter. No government is above the law. Any attempt to sideline the decision of Courts will be resisted by the NBA. This is the only way to secure Peace, Order and good Government in Nigeria." Quoted in SERAP, "Judgments/Resolved Cases," http://serapnigeria.org/judgementsresolved-cases.ngo/.
} 
States in furtherance of the global good governance proposals of the $1990 \mathrm{~s} .{ }^{85}$ Indeed, the Community Court would function under the shadow of the good governance narratives. Although the establishment of these Courts across the developing world were aimed at entrenching globalization in the new international economic order, the peculiar social and political context that the institutions are embedded in determined their trajectory. As it relates to ECOWAS, the following points emerge. The Community Court as it exists today is far from being a regional economic integration or trade liberalization enhancing one. First, Member States of the ECOWAS Community do not sue themselves for disputes or violation of the Community laws relating to economic integration. One of the reasons for the lack of such actions is the commitment that Member States will always explore peaceful means to settle disputes and that adversarial dispute resolution will be a last option. Closely related to this point is that, even where the Member States fail to settle the dispute peaceful, submitting an economic dispute to the jurisdiction of the Community Court is an inherent recognition of its supranational status, from which it would be hard for the concerned members to turn away. In addition, the submitting to the supranational jurisdiction of the Court contradicts the socio-political realities of the Member States, who continue to guard their national sovereignty in the face of globalization and its technologies of governance that has kept them as developing countries. The implication, therefore, is that the Community Court has functioned more as a human rights Court.

\footnotetext{
${ }^{85}$ See Klaus Dingwerth and Philipp Pattberg, "Global Governance as a Perspective on World Politics" (2006) 12 Global Governance, 185-203.
} 
In relation to the community court, the implementation conundrum occurs in the context of the implementation and enforcement of its decisions. However, the decisions of the Court offer a mixed bag of results with varying levels of compliance that make it difficult to speak categorically of its "failure" or "success." In this regard, with a murky picture, the chapter demonstrated the limitation of "traditional" compliance narratives in explicating the "effectiveness" of the Court, even in the context of human rights decisions. To address this conundrum, our notion of "compliance" for the purpose of the ECOWAS Community Court would need to be revisited and broadened to accommodate the informal socio-political ways that these decisions influence events. In any case, such an exercise is outside the purview of the thesis. What is key, as demonstrated in the chapter, is that the varieties of the cases that are litigated before the Court reinforce the claim in this thesis that the ECOWAS Treaties, their institutions and protocols, are embedded in the social relations and structure of the Community Members.

Lastly, the chapter raised a theoretical point that would be relevant for the future interrogation of the framework that underpins the Community Court and ECOWAS. I contended that the overlap in the role of the state and the private individuals as actors with respect to different issues before the Court is symptomatic of the underlying overlap, as opposed to contradiction, between neoliberalism and developmental state in an age of globalization. This hybridity opens new vistas to rethink and conceptualize the sociopolitical relations between ECOWAS Member States and the ECOWAS institutions in ways that would deepen our understanding of the trajectory of the organization in the twenty-first century. 


\section{Chapter 7}

\section{Conclusions: A New Narrative of Regional Economic Cooperation in ECOWAS}

\subsection{Introduction}

In this concluding chapter, I ask how a socio-legal analysis, and in particular contextual reading of ECOWAS, changes the dominant interpretation of the failure of the organization. Regional economic cooperation in ECOWAS is embedded in the sociopolitical and social relations of the Member States. The thesis has examined how changing social, political and economic factors at the international, regional, and national levels influence or shape the implementation of the ECOWAS Treaties and its institutions. The analysis is based on the assumption that since theories of regional economic integration and the legal form of the treaties as developed in the West, and Europe in particular, are inapplicable in African regional economic communities, stricto senso, there is a need to look beyond the traditional analytical models to incorporate the peculiar yet complex social, economic, political realities and possibly cultural features of the region that are implicated in the implementation of the treaties.

In this regard, the thesis explicates the limitation of strict textual analysis or legal formalism in understanding the implementation of the ECOWAS Treaties, as they do not capture the broader socio-political contexts. The analysis of the implementation conundrum of the ECOWAS Treaties interrogated in this thesis foreground the influence 
of historical specificity, social conflicts, power dynamics, and changing international economic and political ideologies (such as those promoted by the Bretton Woods Institutions) as crucial to a deeper understanding of the trajectory of ECOWAS. With changes in the economic development theories and priorities of development agencies and international institutions, as well as the priorities of the ECOWAS Member States, the organization has morphed overtime.

Based on the analysis in the previous chapters, the following conclusions and contributions emerge and will be discussed in order: i) reappraisal of the legacy of ECOWAS Establishing Treaty; ii) reconceptualizing or broadening compliance and effectiveness for the study of ECOWAS; iii) power dynamics, geo-politics, and social conflicts are intrinsic to the implementation conundrum; and lastly, iv) colonial legacies and former imperial powers, particularly from the francophone West African perspective, shed light on the implementation conundrum.

\subsection{Towards a Reappraisal of the Legacy of the ECOWAS Establishing Treaty}

One of the core contributions that emerge from the reconceptualization of regionalism as a social phenomenon is that the dominant failure narrative of the ECOWAS Establishing Treaty is not a universal occurrence; rather, it is relative to the assessment in question. Based on the socio-political and historical nuance that the thesis infuses in the analysis, there is a need to reappraise the legacy of the ECOWAS Establishing Treaty. From the analysis in chapter 4, it is clear that although the ECOWAS Establishing Treaty enshrined 
various regional economic integration aspirations, the practice of the ECOWAS Member States eschewed such lofty aspirations. In other words, save for the technical expression of the Establishing Treaty, the ECOWAS Member States were basically in a regional economic cooperation; essentially more concerned with broader socio-political contexts that shaped their relations as Community members and with the international society. Coming out of colonialism, the new states that comprise ECOWAS Members were primarily concerned with the protection of their political sovereignty. As such, they were not as enthusiastic in committing to regional organizations with potential to fetter their hard-earned sovereignty. While the Member States did not cede sovereignty to ECOWAS, they simultaneously sought ways to restructure the international economic system that was stacked against their interests and overall development in order to consolidate on their economic sovereignty. In this regard, their effort as part of the NIEO movement was not successful. As raw material producing countries with no significantly diversified economies, they were, however, subject to changes in the international economy, and as such were almost always at the receiving end of price fluctuations that they could not control. The implication of this was that, while the Member States consolidated on the political sovereignty, economic sovereignty remains an important tool in the ordering of the regional and international socio-economic relations of the ECOWAS Member States. Regional conflicts, which continue in various contexts today, provide an added layer of complexity to the socio-economic and political aspirations of ECOWAS Member States in the early years of regional cooperation in West Africa. Indeed, regional social conflicts as they manifest in various guises remain a significant factor in the implementation of ECOWAS today. Situated in the socio-political context of 
its implementation, the analysis in the thesis demonstrates the limitation of the mainstream narrative of failure of the ECOWAS Establishing Treaty.

Hence, while "important" changes were made to the Revised ECOWAS Treaty by the establishment of new institutions that basically reproduced the marque techniques of the era of global governance, the underlying social relations of the ECOWAS Member States have not evolved. Rather, continuities with respect to the protection of their national sovereignty and cooperation outside trade liberalization as well as dissidence toward supranational authority in the region remain at the centre of the socio-economic and political relations of the ECOWAS Community. Indeed, with good governance agenda firmly entrenched in the protocols of ECOWAS, the trajectory of the organization has been more explicitly defined by concerns with the democracy, rule of law, protection of human rights, security, and so forth. These complex regional and international factors that shape the trajectory of ECOWAS require more nuance in our assessment of the implementation conundrum, and to speak categorically of failure or success blurs important contributions that ECOWAS may be making in the region.

In other words, without the context, the implementation conundrum looks like failure; with the context, it becomes a complex process of ordering of various and, at times, competing socio-economic and political objectives. There is, therefore, a need to revisit the dominant interpretations of the failure of the organization. Such an assessment that takes into account the broad socio-political complexities would illuminate and deepen our 
understanding of the implementation conundrum of ECOWAS in the post-colony and globalized world order.

\subsection{Reconceptualizing Effectiveness and Compliance for the study of ECOWAS Treaties}

Another insight that emerges from the thesis is that the traditional understanding of "effectiveness" or "compliance" underpinned by legal formalism is insufficient to capture the myriad informal ways that the implementation of ECOWAS affects the Member States or their nationals. The most recent example that reinforces the case for broadening traditional conceptualization of effective compliance or enforcement to include informal approaches for the study of ECOWAS relates to the diplomatic manner that ECOWAS handled the democratic change in The Gambia. Following the emergence of Adama Barrow as the president-elect in a fiercely contested national election, it became apparent as reported in the media that the sitting president Yahya Jammeh was not going to relinquish power voluntarily. Nigeria, Senegal, and Ghana, with support from other Member States and the United Nations Security Council, mediated and averted a potential constitutional crisis in The Gambia that resulted in the former President Jammeh proceeding on exile. ${ }^{1}$ The success of the effort not only averted a potential political violence in the country, but it also ensured that there was no constitutional vacuum and that the rule of law, particularly with respect to upholding the results of the elections that represent the collective will of the peoples of The Gambia, was upheld. Through this

\footnotetext{
${ }^{1}$ See Paul D. Williams, "A New African Model of Coercion? Assessing the ECOWAS Mission in The Gambia," International Peace Institute Global Observatory, 16 March 2017, https://theglobalobservatory.org/2017/03/ecowas-gambia-barrow-jammeh-african-union/.
} 
effort, ECOWAS is indeed implementing its political and good governance commitments, without the formal adversarial system of the Court. $^{2}$

In order to engage in a meaningful normative analysis that examines the impact of the ECOWAS Treaties as their implementation is shaped by socio-political and regional conflicts, the traditional understanding of effectiveness or compliance would require a broadening or reconceptualization that is not wedded to the mainstream perspective that relies solely on the Court and draws a line from the decisions to their implementation. Particularly, the reconceptualization would be broadened to account for soft norms and informal ways that the implementation of ECOWAS impacts the socio-economic and political relations of its Member States. Although this is not the first time that such a call has been made, the enlarged conceptualization of effectiveness and compliance has not been applied to the study of regional economic cooperation schemes in Africa.

In the context of the analysis of the impact of Africa human rights courts, drawing on a constructivist analysis of the decisions emerging from the courts, Obiora Okafor urged scholars and other observers of the African system to reach beyond, while retaining state compliance as the key measure of the worth of Community courts, to seek analysis that supplements and complements pre-existing conceptual approaches "toward an enlarged conceptual optic for understanding" the African regional system. ${ }^{3}$ An enlarged conceptualization of effectiveness in the context of ECOWAS and its institutions "would

\footnotetext{
${ }^{2}$ See Paul Nantulya, "Lessons from Gambia on Effective Regional Security Cooperation," Africa Center for Strategic Studies, 27 March 2017, http://africacenter.org/spotlight/gambia-regional-securitycooperation/.

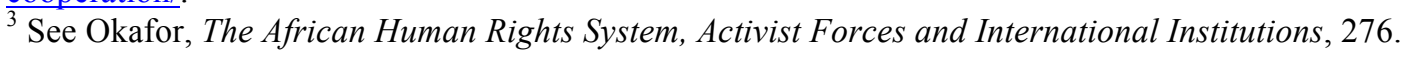


[while eschewing its complete abandonment] reach beyond the compliance-focused frame of reference....It will...seek to observe the various ways in which...norms become embedded in, and therefore influential within [the region] or are otherwise creatively deployed by local activist forces so as to persuade the relevant actors to alter their...logics of appropriateness. ${ }^{\prime 4}$ Such an enlarged understanding of effectiveness and compliance would also provide a framework through which to account for the role of individuals and other actors in regional economic cooperation in contemporary ECOWAS and the Community Court.

\subsection{Impact of Power Dynamics, Geo-Political and Social Conflicts}

Another insight that emerges from the analysis relates to the impact of power dynamics, geo-political and social conflicts in the implementation of the ECOWAS Treaties. Based on the reconceptualization of regionalism as a social phenomenon, its institutions are interpreted as socially constructed and embedded in the historical practices, norms, sociopolitical, and symbolic relations of the Community Members. The formal and informal socio-economic relations of the Member States are conducted in the shadow of the power relations and the social structures of the West African sub-region. ${ }^{5}$

The empirical analysis in the thesis demonstrates the historical and contemporary contingency of power in the relations among the Community Members, with international

\footnotetext{
${ }^{4}$ Ibid., 285.

${ }^{5}$ See Daniel Flemes, "Conceptualizing Regional Power in International Relations: Lessons from the South African Case," German Institute of Global and Area Studies Working Papers No. 53, June 2007, 1-59, https://www.giga-hamburg.de/de/system/files/publications/wp53 flemes.pdf.
} 
institutions, as well as in their relations with the Community institutions like the Community Court. The salience of power in the relations of the Community Members in the context of economic and financial resources has evolved overtime. While Nigeria remains a powerful country in the region with significant economic and human resources, other countries, such as Ghana and Senegal, though not as endowed, are engaged in power struggles that are crucial to the implementation of the ECOWAS Treaties. While these insights emerge from the analysis in the thesis, more empirical research would be required to document the specific ways that they impact the implementation conundrum in ECOWAS.

Similarly, the thesis illuminates the impact of power in the context of geo-political and social conflicts on the implementation of the ECOWAS Treaties. Regional trade agreements have the potential to escalate tensions; divisiveness and their terms are embedded in social conflicts and power imbalances among the Member States particularly where the countries involved have differing economic power. In the ECOWAS Community, Nigeria, with economic, political, and military strength is able to exert power not only in the regional but also in the international diplomacy of the Community as a regional hegemon. In this regard, the thesis draws on the example of the Economic Partnership Agreement with the European Union. The analysis is made much more complex by the fact that other countries in the region have also resorted to retaliatory policy and legal measures to counter the influence of Nigeria in the region with a view to also protecting their national economies. This aspect of the narrative of ECOWAS would require further study to document the interconnectedness of power and 
its exploitation in times of geo-political and social conflicts not only for insights on how it benefits particular Member States but also to enrich our understanding of the embedded distrust in the Community and overall implementation of the ECOWAS Treaties.

\subsection{Colonial Legacies, Continuing Influence of Imperial Powers, and International Institutions}

A fourth conclusion that emerges from the thesis is that colonial legacies, particularly in the context of Francophone ECOWAS Members, international institutions and influence of imperial powers remain a vital factor in the implementation of the ECOWAS Treaties.

Although colonialism has ended, the legacies remain with consequences for the social relations among the Community members. ${ }^{6}$ The analyses in relation to the Economic Partnership Agreement and the good governance narratives are examples of different ways that the binary relationship between the ECOWAS Member States and imperial powers shape the implementation of the treaties today. New technologies of global governance, particularly through transnational corporations and international institutions, continue to be deployed with influence on the implementation of the ECOWAS Treaties. For example, while many poorer ECOWAS Member States were quick to conclude the Economic Partnership Agreement with the EU as it ensures the flow of development assistance to these countries, the richer countries, such as Nigeria and Ghana, have not been as eager. The point is that continuities and discontinuities of colonial legacies,

\footnotetext{
${ }^{6}$ See, Frederick Cooper, "Development, modernization, and the Social Sciences in the Era of Decolonization: the Examples of British and French Africa", (2004) 1(10) Revue D'Histoire Des Sciences Humaines, pp. 9-38Alexander Lee and Kenneth A. Schultz, "Comparing British and French Colonial Legacies: A Discontinuity Analysis of Cameroon”, (2012) 7 Quarterly Journal of Political Science, pp. 146.
} 
influence of imperial powers, and international institutions shaped, and continue to shape, the economic relations of the ECOWAS Community today.

In conclusion, the aim in this thesis has been to illuminate, through a socio-legal analysis, the complexity, fluidity, interactions, and embedded economic, social, political and historical contexts that shape the implementation of the ECOWAS Treaties. In so doing, the thesis challenges the dominant narrative of failure of the organization. While ECOWAS has come a long way, and the failure critique may hold strength in relation to trade liberalization, the wider narrative of the socio-political implementation of the organization based on its multiple objectives that cut across the social and political realms makes an assessment of the success or failure a harder task. While opening up more questions for future analysis, this thesis has injected some nuance into the implementation conundrum in ECOWAS. 


\section{BIBLIOGRAPHY}

Legislation: Treaties, Protocols, Declarations, and Other International Agreements

\section{East African Community}

East African Community Treaty of 2010.

\section{ECOWAS}

Declaration A/DCL.1/7/91 of Political Principles of the Economic Community of West African States.

Economic Community of West African States Revised Treaty, 24 July 1993.

Economic Community of West African States Treaty, 28 May 1975.

ECOWAS Community Court of Justice Protocol, A/P/I/7/91.

ECOWAS Parliament, "Final Communiqué of the 50 Ordinary Summit of the Authority of Heads of State and Government," 17 December 2016.

ECOWAS Protocol on Movement of Persons and Establishment, A/P1/5/79.

Protocol A/P.2/8/94 Relating to the Community Parliament.

Protocol A/SP1/12/01 on Democracy and Good Governance Supplementary Protocol relating to Mechanism for Conflict Prevention, Management, Resolution, Peacekeeping and Security.

Protocol Relating to the Mechanism for Conflict Prevention, Management, Resolution, Peacekeeping and Security, 1999.

Supplementary Act A/SA.1/12/16 Relating to the Enhancement of the Powers of the ECOWAS Parliament.

Supplementary Protocol A/SP.1/01/05 Amending the Preamble and Articles 1, 2, 9, and 30 of Protocol A/P.1.91.

Supplementary Protocol A/SP.1/6/89 Amending and Complementing the Provisions of Article 7 of the Protocol on Free Movement of Persons, the Right of Residence and Establishment. 
Supplementary Protocol A/SP.1/7/85 on the Code of Conduct for the Implementation of the Protocol on Free Movement of Persons, the Right of Residence and Establishment.

Supplementary Protocol A/SP.1/7/86 on the Second Phase (Right of Residence).

Supplementary Protocol A/SP.3/06/06 Amending Protocol A/P.2/8/94 Relating to the Community Parliament.

\section{United Nations}

United Nations General Assembly, Declaration on the Establishment of a New International Economic Order, Resolution 3201 (S-VI), 1 May 1974.

United Nations General Assembly, Programme of Action on the Establishment of a New International Economic Order, Resolution 3202 (S-VI).

\section{SECONDARY MATERIAL: MONOGRAPHS}

Abrahamsen, Rita. Disciplining Democracy: Development Discourse and Good Governance in Africa. London: Zed Books, 2009.

Acharya, A., and A. I. Johnston, eds. Crafting Cooperation: Regional International Institutions in Comparative Perspective. Cambridge, Cambridge University Press, 2007.

Akinkugbe, Olabisi D. "Review of African Regional Trade Agreements as Flexible Legal Regimes." (2013) 112:446 African Affairs, 157-59.

—. "Review of Legal Aspects of Economic Integration in Africa." (2015) Journal of International Economic Law, 1-4.

Asante, S. K. B. Regionalism and Africa's Development, Expectations, Reality and Challenges. Great Britain: McMillan Press Limited, 1997.

- The Political Economy of Regionalism in Africa: A Decade of the Economic Community of West African States (ECOWAS). New York: Praeger Special Studies, 1986.

Banakar, Reza, and Max Travers, eds. Theory and Method in Socio-Legal Research. Oxford: Hart Publishing, 2005.

Bayart, Jean-Francois. The State in Africa: Politics of the Belly. 2nd ed. Cambridge: Cambridge University Press, 2009.

Bedjaoui, Mohammed. Towards a New International Economic Order. New York: Holmes \& Meier Publishers, 1979. 
Börzel, Tanja A., Lukas Goltermann, and Kai Striebinger, eds. Roads to Regionalism: Genesis, Design, and Effects of Regional Organizations Burlington, UK: Ashgate, 2012.)

Chambers, V., M. Foresti, and D. Harris. Final Report: Political Economy of Regionalism in West Africa-Scoping Study and Prioritisation. London: ODI, 2012.

Cheeseman, Nic. Democracy in Africa: Success, Failures and the Struggle for Political Reform. Cambridge: Cambridge University Press, 2015.

Chime, Chimelu. Integration and Politics among African States: Limitations and Horizons of Mid-term Theorizing. Uppsala: The Nordic Institute of African Studies, 1977.

Clapham, Christopher. Africa and the International System. The Politics of State Survival. Cambridge: Cambridge University Press, 1996.

Cooper, Frederick. Africa since 1940: The Past of the Present. Cambridge: Cambridge University Press, 2002.

Cotterrell, Roger. Law, Culture and Society: Legal Ideas in the Mirror of Social Theory. Farnham: Ashgate, 2006.

Cowan, David, and Daniel Wincott, eds. Exploring the 'Legal' in Socio-Legal Studies. New York: Palgrave Macmillan, 2015.

Edi, Eric M., Globalization and Politics in the Economic Community of West African States. Durham, NC: Carolina Academic Press, 2007.

Escobar, Arturo. The Making and Unmaking of the Third World. Princeton, NJ: Princeton University Press, 1995.

Falola, Toyin, and Julius O. Ihonvbere, eds. Nigeria and the International Capitalist System. London: Lynne Rienner, 1988.

Feenan, Dermont, ed. Exploring the 'Socio' of Socio-Legal Studies. New York: Palgrave Macmillan, 2013.

Galligan, D. J. Law in Modern Society. Clarendon Law Series. Oxford: Oxford University Press, 2007.

Gambari, Ibrahim. Political and Comparative Dimensions of Regional Integration: The Case of ECOWAS. Atlantic Highlands, NJ: Humanities Press International, 1991. 
Gathii, James Thuo. African Regional Trade Agreements as Flexible Legal Regimes. Cambridge: Cambridge University Press, 2011.

Grant, Andrew, and Frederick Söderbaum, eds. The New Regionalism in Africa. Aldershot: Ashgate, 2003.

Gruber, Lloyd. Ruling the World: Power Politics and the Rise of Supranational Institutions. (Princeton, NJ: Princeton University Press, 2000.

Haas, Ernst B., The Uniting of Europe: Political, Social and Economic Forces 1950-57. Stanford: Stanford university Press, 1958.

Hudec, Robert E. Developing Countries in the GATT/WTO Legal System. London: Gower Publishing Limited, 1987.

Jackson, John H. The World Trading System: Law and Policy of International Economic Relations. Cambridge/London: The MIT Press, 1989.

Jaye, Thomas, Dauda Garuba, and Stella Amadi, eds., ECOWAS \& the Dynamics of Conflict and Peace Building. (Dakar: CODESRIA, 2011.

Karen Alter. The New Terrain of International Law: Courts, Politics, Rights. Princeton, NJ: Princeton University Press, 2014.

Kufuor, Kofi Oteng. The Institutional Transformation of the Economic Community of West African States. England: Ashgate, 2006.

Mkandawire, T., and C. C. Soludo. Our Continent, Our Future: African Perspectives on Structural Adjustment. Dakar: Council for the Development of Social Science Research in Africa, 1999.

North, Douglass C. Institutions, Institutional Change and Economic Performance. Cambridge: Cambridge University Press, 1990.

Nye, Joseph. Pan-Africanism and East African Integration. Cambridge, MA: Harvard University Press, 1965.

Obiozor, G. A., A. O. Olukoshi, and C. I. Obi, eds. West African Regional Economic Integration: Nigerian Policy Perspectives for the 1990s. Uppsala: Nordiska Afrikainstitutet, 1999.

Okafor, Obiora Chinedu. The African Human Rights System, Activist Forces and International Institutions. Cambridge: Cambridge University Press, 2007. 
Oloruntoba, Samuel. Regionalism and Integration in Africa: EU-ACP Economic Partnership Agreements and Euro-Nigeria Relations. New York: Palgrave Macmillan, 2016.

Ropke, William. International Order and Economic Integration. Holland: D. Reidel Publishing Company, 1959.

Söderbaum, Fredrik. The Political Economy of Regionalism: The Case of Southern Africa. New York: Palgrave Macmillan, 2004.

—, and Timothy Shaw. Theories of New Regionalism. New York: Palgrave Macmillan, 2004.

Tamanaha, Brian. Realistic Socio-Legal Theory: Pragmatism and a Social Theory of Law. Oxford: Clarendon Press, 1999.

The World Bank. Governance: The World Bank’s Experience. (World Bank, 1994.

Trommer, Silke. Transformations in Trade Politics: Participatory Trade Politics in West Africa. London: Routledge, 2014.

Trubek, David M., Helena Alviar Garcia, Diogo R. Coutinho, and Alvaro Santos, eds. Law and the New Developmental State: The Brazilian Experience in Latin American Context, Cambridge: Cambridge University Press, 2013.

Ukaigwe, Jerry. ECOWAS Law. London: Springer International Publishing, 2016.

Viner, Jacob. The Customs Union Issue. New York: Carnegie Endowment for International Peace, 1950.

- The Political Economy of Regionalism in Africa: A Decade of the Economic Community of West African States (ECOWAS). New York: Praeger Special Studies, 1986.

\section{SECONDARY MATERIALS: BOOK CHAPTERS AND JOURNAL ARTICLES}

Abrahamsen, Rita. "The World Bank's Good Governance Agenda, Narratives of Democracy and Power." In Ethnographies of Aid; Exploring development texts and encounters, International Development Studies, Occasional Paper, 15-44.

Acharya, A., and A. I. Johnston, "Comparing Regional Institutions: An Introduction." In Crafting Cooperation: Regional International Institutions in Comparative Perspective, edited by Acharya, A. and A. I. Johnston, 1-31. Cambridge: Cambridge University Press, 2007. 
Adebajo, Adekeye. "Two Prophets of Regional Integration: Prebisch and Adedeji." In International Development: Ideas, Experience, and Prospects, edited by Bruce Currie-Alder, Ravi Kanbur, David M. Malone, and Rohinton Madhora, 323-38. Oxford: Oxford University Press, 2014.

—. "A Tale of Two Prophets: Jean Monnet and Adebayo Adedeji." In African Development in the 21st Century: Adebayo Adedeji's Theories and Contributions, edited by Amos Sawyer, Afeikhena Jerome, and Ejeviome Eloho Otobo, 77-90. Asmara and Trenton: Africa World Press, 2014.Banjo, Adewale. "The ECOWAS Court and the Politics of Access to Justice in West Africa." (2007) 32:1 Africa Development, 69-87.

Adedeji, Adebayo. "Collective Self-Reliance in Developing Africa: Scope, Prospects and Problems" Keynote Address at the International Conference on the Economic Community of West African States, Lagos. 23-27 August 1976.

—. "History and Prospects for Regional Integration in Africa." Speech delivered at the Third Meeting of the African Development Forum, Addis Ababa, 5 March, 2002.

Adjolohoun, Horace S. "AJIL Symposium: Can the ECOWAS Court Revive Regionalism through Human Rights?." 4 February 2014 (Online).

Aghaji, J. C. "ECOWAS: Is it a Countervailing Power for Economic Independence?" (1979) 14:1-2 Journal of Asian and African Studies, 110

Ajulo, Sunday Babalola. "The Economic Community of West African States and International Law." (1989) 27:2 Journal of Modern African Studies, 233-50.

- "Sources of the Law of the Economic Community of West African States (ECOWAS)." (2001) 45:1 Journal of African Law, 73-96.

Ajumbo, Gerald. "Is Variable Geometry Leading to the Fragmentation of Regional Integration in East Africa?." 7 November, 2013.

Akinrinsola, Iwa. "Legal and Institutional Requirements for West African Economic Integration." (2004) 10 Law and Business Review of the Americas, 493-514.

Akoutou, Ablam Benjamin, Rike Sohn, Matthias Vogl, Daniel Yeboah, eds. Understanding Regional Integration in West Africa-A Multi-Thematic and Comparative Analysis. West African Institute-Centre for European Integration Studies Paper No. 17. 2014.

Allain, Jean. "Hadijatou Mani Koraou v. Republic of Niger. Judgment No. ECW/CCJ/JUD/06/08." (2009) 103:2 American Journal of International Law, $311-17$. 
Alter, Karen J., Laurence R. Helfer, and Jacqueline R. McAllister, “A New International Human Rights Court for West Africa: The ECOWAS Community Court of Justice." (2013) 107:737 American Journal of International Law, 737-779.

— Comparative Regionalism, edited by Tanja A. Börzel and Thomas Risse, 538558. Oxford: Oxford University Press, 2016.

Alvarez, Jose E. "How Not to Link: Institutional Conundrums of an Expanded Trade Regime." (2001) 7 Widener Law Symposium Journal, 15.

Amadu Sesay, Amadu, and Moshood Omotosho, "The Politics of Regional Integration in West Africa." (2011, October) 2:2 WACSERIES, 1-36.

Anang, Emmanuel Kwesi. "Investing in Peace \& Security in Africa: the Case of ECOWAS.” (2004) 4:3 Conflict, Security \& Development, 533-42.

Andrew, Grant J., and F. Söderbaum, eds. The New Regionalism in Africa Aldershot: Ashgate, 2003.

Annan, N. "Violent Conflicts and Civil Strife in West Africa: Causes, Challenges and Prospects." (2014) 3:1 Stability: International Journal of Security and Development.

Asante, S. K. B. "Development and Regional Integration Since 1980." In Economic Crisis in Africa: African Perspectives on Development Problems and Potentials, edited by A. Adedeji and T. M. Shaw. Boulder, CO: Lynne Rienner Publishers, 1985.

- Report on an Advisory Mission on Review of the ECOWAS Treaty-Regional Economic Cooperation and Integration Options, ECO/RA/91/1.

—. "The Strategy of Regional Integration in Africa." United Nations Economic Commission for Africa, Text of two lectures delivered at a Public Forum organized by the Foreign Affairs Committee of Ghana Parliament in collaboration with Friedrich Ebert Stiftung, Ghana, Ministry of Foreign Affairs and the Legon Centre for International Affairs, University of Ghana, Legon, Accra, Ghana, 25 and 26 September, 1996.

Bach, Daniel C. "Regionalism in Africa: Concepts and Context" in James Hentz (ed.) Routledge Handbook of African Security, (2013: Routledge, London), pp. 181189.

. "Regionalism vs. Regional Integration: The Emergence of a New Paradigm in Africa." In Regionalism Across the North/South Divide: State Strategies and 
Globalization, edited byJean Grugel and Wil Hout, 136-48. London: Routledge, 1999.

- "The Politics of West African Economic Co-operation: C.E.A.O. and E.C.O.W.A.S." (1983) 2 vol., 21:3 Journal of Modern African Studies, 605-623.

Beckman, Björn. "The Liberation of Civil Society: Neo-Liberal Ideology and Political Theory." (1993) 58 Review of African Political Economy, 20-33.

Berg-Schlosser, Dirk. "Indicators of Democracy and Good Governance as Measures of the Quality of Democracy in Africa: A Critical Appraisal." (2004) 39:3 Acta Politica, 248-278.

Bienefeld, Manfred "Dependency Theory and the Political Economy of Africa's Crisis." (1988) 15:43 Review of African Political Economy, 68-87.

Bix, Brian H. "Legal Positivism." In Blackwell Guide to Philosophy of Law and Legal Theory, edited by Martin P. Golding and William A. Edmundson, 29-48. Malden, MA: Blackwell, 2005.

Bøås, Morten. "Regions and Regionalisation: A Heretic's View." In Regionalism and Regional Integration in Africa: A Debate of Current Aspects and Issues, 27-39. Uppsala: Nordiska Afrikainstitutet, 2001.

Börzel, Tanja A. "Comparative Regionalism: A New Research Agenda." KFG Working Paper Series, No. 28, August 2011. Kolleg-Forschergruppe (KFG) "The Transformative Power of Europe," Freie Universität Berlin, 9-10.

—- Lukas Goltermann, and Kai Striebinger, eds. Roads to Regionalism: Genesis, Design, and Effects of Regional Organizations Burlington, UK: Ashgate, 2012.)

Breslin, Shaun, Richard Higgott, and Ben Rosamond, "Regions in Comparative Perspective." In New Regionalisms in the Global Political Economy, edited by S. Breslin, C. Hughes, N. Philips, and B. Rosamond. London: Routledge, 2002.

Brown, Oli, Faisal Haq Shaheen, Shaheen Rafi Khan, and Moeed Yusuf, "Regional Trade Agreements: Promoting Conflict or Building Peace?." (2015) International Institute for Sustainable Development, 1-20.

Brown, Stephen. "Foreign Aid and Democracy Promotion: Lessons from Africa." (2005) 17:2 European Journal of Development Research, 179-98.

Carmody, P. "Constructing Alternatives to Structural Adjustment in Africa." (1998) 25:75 Review of African Political Economy, 25-46. 
Cerny, P. "Globalizing the Political and Politicizing the Global: Concluding Reflections on International Political Economy as a Vocation." (1999) 4:1 New Political Economy, 147-62.

Chacha, Mwita. "Regional Integration and the Challenge of Overlapping Memberships on Trade." (2014) 17:4 Journal of International Relations and Development, 52244.

Chibundu, Maxwell O. "NEPAD and the Rebirth of Development Theory and Praxis." In Africa: Mapping New Boundaries in International Law, edited by Jeremy Levitt. Oxford: Hart Publishers, 2008.

Christof, Hartman. "ECOWAS and the Restoration of Democracy in The Gambia." (2017) 52:1 Africa Spectrum, 85-99.

Cooper, Frederick. "Development, Modernization, and the Social Sciences in the Era of Decolonization: the Examples of British and French Africa." (2004) 1:10 Revue d'Histoire Des Sciences Humaines, 9-38.

Cotterrell, Roger. "Transnational Networks of Community and International Economic Law.” In Socio-Legal Approaches to International Economic Law: Text, Context, Subtext, edited by Amanda Perry-Kessaris, 133-50. New York: Routledge, 2013.

—. "Why Must Legal Idea Be Interpreted Sociologically?."(1998) 25:2 Journal of Law and Society, 171-192.

Cownie, C., and A. Bradney. "Socio-Legal Studies: A Challenge to the Doctrinal Approach." In Research Methods in Law, edited by D. Watkins and M. Burton. Abingdon: Routledge, 2011.

d'Aspremont, Jean. "Formalism versus Flexibility in the Law of Treaties." In Research Handbook on the Law of Treaties, edited by Christian J. Tams, Antonios Tzanakopoulos, and Andreas Zimmermann. Cheltenham: Edward Elgar Publishing, 2014.

Deme, Mamit. "The Impact of ECOWAS on Intraregional Trade Flows: An Empirical Investigation." (1995) 23:3 Review of Black Political Economy, 113-29.

Diaby-Ouattara, Aboubakar. "A New Look at the Process of Economic Integration: An Address." In Trade \& Development in Economic Community of West African States, edited by Adeyinka Orimalade and R. E. Ubogu, 19-22. New Delhi:Vikas Publishing House PVT, 1984.

Diallo, Mamadou Alpha. "Regional Integration in West Africa (1960-2015): Balance and Perspectives.” (2016) 1:1 Brazilian Journal of African Studies, 234-54. 
Dieter, Heribert, and Richard Higgot, "Exploring Alternative Theories of Economic Regionalism: From Trade to Finance in Asian Co-operation." The University of Warwick Centre for the Study of Globalisation and Regionalisation Working Paper No. 89/02, January 2002.

Dingwerth, Klaus, and Philipp Pattberg, "Global Governance as a Perspective on World Politics.” (2006) 12 Global Governance, 185-203.

Doidge, Mathew. "From Developmental Regionalism to Developmental Interregionalism? The European Union Approach.” NCRE Working Paper No. 07/01, July 2007.

Dollar, David, and Jakob Svensson. "What Explains the Success or Failure of Structural Adjustment Programmes?.” (2000) 110 Economic Journal, 894-917.

Drobak, John N. "Introduction: Law \& The New Institutional Economics." (2008) 26 Washington University Journal of Law and Policy, 1-11.

D’Souza, Radha. "Socio-Legal Studies: Neo-Liberalism and Lessons from India's Legal Innovations." (2005) 14 Social and Legal Studies, 487-513.

Duffy, Helen. "Hadijatou Mani Koroua [sic] v. Niger: Slavery Unveiled by the ECOWAS Court." (2009) 9:1 Human Rights Law Review, 151-70.

Easterly, William. "What Did Structural Adjustment Adjust? The Association of Policies and Growth with Repeated IMF and World Bank Adjustment Loans." (2005) 76 Journal of Development Economics, 1-22.

Ebobrah, Solomon T. "Critical Issues in the Human Rights Mandate of the ECOWAS Court of Justice." (2010) 54 Journal of African Law.

—. "The Role of the ECOWAS Community Court of Justice in the integration of West Africa: Small Strides in the Wrong Direction?." iCourts Working Paper Series, No. 27, June 2015.

—. "AJIL Symposium: Comment on a New International Human Rights Court for West Africa.” 3 February 2014, (Online).

Edigheji, Omano. "A Democratic Developmental State in Africa? A Concept Paper." Research Report, Center for Policy Studies, May 2005, Johannesburg, 1-18.

Enabulele, A. O. "Sailing Against the Tide: Exhaustion of Domestic Remedies and the ECOWAS Community Court of Justice." (2012) 56:2 Journal of African Law, 268-295. 
Erasmus, Gerhard. "Is the SADC Trade Regime a Rules-Based System?." (2011) 1:1 Southern African Development Community Law Journal, 17-35.

Ethier, Wilfred J. “The New Regionalism.” (1998) 108 Economic Journal, 1149-61.

Ewing-Chow, M. "Culture Club or Chameleon: Should ASEAN Adopt Legalization for Economic Integration?." (2008) 12 Singapore Yearbook of International Law, 225.

Fanta, Emmanuel. "Understanding Regional Integration Policies in Africa." In Comparative Regionalisms for Development in the 21st Century: Insights from the Global South, edited by Vanessa T. Tang, Timothy M. Shaw, and Emmanuel Fanta, 41-56. England: Ashgate, 2013.

Fawcett, L., and H. Gandois. "Regionalism in Africa and the Middle East: Implications for EU Studies.” (2010) 32:6 Journal of European Integration, 617-36.

Feeley, Malcolm M. "The Concept of Laws in Social Science: A Critique and Notes on an Expanded View." (1976) 10 Law and Society Review, 501.

Flew, Terry. "Six Theories of Neoliberalism." (2014) 122:1 Thesis Eleven, 49-71.

Frerichs, Sabine. "Law, Economy and Society in the Global Age: A Study Guide." In Socio-Legal Approaches to International Economic Law: Text, Context, Subtext, edited by Amanda Perry-Kessaris, 36-49. New York: Routledge, 2013.

—. "Studying Law, Economy, and Society: A Short History of Socio-Legal Thinking." University of Helsinki, Faculty of Law, Legal Studies Research Paper Series, Paper No 19, 1-80, SSRN: https://ssrn.com/abstract=2022891.

Gammage, Clair. "Protecting Human Rights in the Context of Free Trade? The Case of the SADC Group Economic Partnership Agreement." (2014) 20:6 European Law Journal, 779-92.

. "(Re)conceptualising International Economic Law: A Socio-Legal Approach to Regionalism." In Socio-Legal Approaches to International Economic Law: Text, Context, Subtext, edited by Amanda Perry-Kessaris, 64-76. New York: Routledge, 2013.

Gathii, James Thuo. "A Critical Appraisal of the NEPAD Agenda in Light of Africa's Place in the World Trade Regime in an Era of Market Centered Development." (2003) 13 Transnational Law \& Contemporary Problems, 179.

—. "International Law and Eurocentricity." (1998) 9 European Journal of International Law, 184-211. 
- "Representations of Africa in Good Governance Discourse: Policing and Containing Dissidence to Neo-Liberalism." (1998-1999) 18 Third World Legal Studies, 65-108.

—. "Retelling Good Governance Narratives on Africa's Economic and Political Predicaments: Continuities and Discontinuities in Legal Outcomes Between Markets and States.” (2000) 45 Villanova Law Review, 971.

—. "The Status of African Regional Trade Agreements." (2013) 4 European Yearbook of International Economic Law, 287-351.

Ghai, Yash P. "Reflections on Law and Economic Integration in East Africa." Research Report No. 36, Scandinavian Institute of African Studies, Uppsala, Sweden, 1976, $9-10$.

Gilman, Nils. "The New International Economic Order: A Reintroduction." (2015) 6:1 Humanity: An International Journal of Human Rights, Humanitarianism, and Development.

Golub, Stephen S. "Entrepot Trade and Smuggling in West Africa: Benin, Togo and Nigeria." (2012) The World Economy, 1-23.

Granovetter, M. 'Economic Action and Social Structure: The Problem of Embeddedness." (1985) 91:3 American Journal of Sociology, 481-510.

- 'Economic Institutions as Social Constructions: A Framework for Analysis." (1992) 35:1 Acta Sociologica, 3-11.

_. 'The Impact of Social Structure on Economic Outcomes." (2005) 19:1 Journal of Economic Perspectives, 33-50.

. "A Theoretical Agenda for Economic Sociology." In Economic Sociology at the Millennium, edited by Mauro F. Guillen, Randall Collins, Paula England, and Marshall Meyer. New York: Russell Sage Foundation, 2001.

Griffin, Christopher. "French Military Policy in the Nigerian Civil War, 1967-1970." (2015) 26:1 Small Wars \& Insurgencies, 114-35.

Haas, Ernst, B. "The Study of Regional Integration: Reflections on the Joy and Anguish of Pretheorizing." (1970) 24:4 International Organization, 607-46.

_. "International Integration and the Universal Process." (1961) 15:3 International Organization, 366-92. 
Heidhues, Franz, and Gideon Obare. "Lessons from Structural Adjustment Programmes and their Effects in Africa." (2011) 50:1 Quarterly Journal of International Agriculture, 55-64.

Helfer, Laurence R. "Sub-regional Courts in Africa: Litigating the Hybrid Right to Freedom of Movement." 15 I-CON: International Journal of Constitutional Law (forthcoming).

- and Anne-Marie Slaughter, "Towards a Theory of Effective Supranational Adjudication." 107 Yale Law Journal, 273-291.

Hentz, James J., and Morten Boas, eds., New and Critical Security and Regionalism: Beyond the National State. Aldershot: Ashgate, 2003.

Hettne, Björn. "The New Regionalism Revisited." In Theories of New Regionalism, A Palgrave Reader, edited by Frederik Söderbaum and Timothy Shaw. New York: Palgrave Macmillan, 2003.

, and Fredrik Söderbaum. “The New Regionalism Approach.” (1998) 17:3 Politeia, 1-18 (pre-publication copy).

Economy, 457-73.

. "Regional Cooperation: A Tool for Addressing Regional and Global Challenges." In International Task Force on Global Public Goods, Achieving Global Public Goods. 179-244. Stockholm: Foreign Ministry.

Hirsch, M. "The Sociology of International Economic: Sociological Analysis of the Regulation of Regional Trade Agreements in the World Trading System.” (2008) 19(2) European Journal of International Law, 277-99.

Hodgson, Geoffrey M. "What is the Essence of Institutional Economics?." (2000) 26:2 Journal of Economic Issues, 317-29.

Hopner, Martin, and Armin Schafer. "Embeddedness and Regional Integration: Waiting for Polanyi in a Hayekian Setting." (2012) 66 International Organization, 42955 .

Iheduru, Okechukwu C. "The New ECOWAS: Implications for the Study of Regional Integration." In The Ashgate Companion to Regionalism, edited by Timothy M. Shaw, J. Andrew Grant, and Scarlett Cornelissen, 213-39. Farnham: Ashgate Publications, 2011. 
Johnson, Chalmers. "The Developmental State: Odyssey of a Concept." In The Developmental State, edited by Meredith Woo-Cumings, 32-60. Cornell, CA: Cornell University Press, 1999.

Kennedy, David. "The Rule of Law, Political Choices, and Development Common Sense." In The New Law and Economic Development: A Critical Appraisal, edited by David M. Trubek and Alvaro Santos, 95-173. Cambridge: Cambridge University Press, 2006.

Kennedy, Duncan. "Legal Formalism." In Encyclopaedia of the Social and Behavioural Sciences, edited by Neil J. Smelser and Paul B. Baltes, 8634-38. vol. 13. Elsevier, 2001.

—. "Three Globalizations of Law and Legal Thought: 1850-200." In The New Law and Economic Development: A Critical Appraisal, edited by David M. Trubek and Alvaro Santos, 19-73. Cambridge: Cambridge University Press, 2006.

Kohnert, Dirk. "African Agency and the EU-African Economic Partnership Agreements." (2014) 49:3 African Spectrum, 149-55.

Koskenniemi, Martti. "Colonial Laws: Sources, Strategies and Lessons?." (2016) 18 Journal of the History of International Law, 248-77.

Krapohl, Sebastian, Katharina L. Meissner, and Johannes Muntschick. "Regional Powers as Leaders or Rambos? The Ambivalent Behaviour Brazil and South Africa in Regional Economic Integration." (2014) 52: 4 Journal of Common Market Studies, 879-95.

Kufuor, Kofi Oteng. "AJIL Symposium: Regional Courts, Regionalism, Critical Junctures and Economic Integration in Africa." Opinion Juris, 3 February 2014.

—. "Law, Power, Politics and Economics: Critical Issues Arising out of the New ECOWAS Treaty." (1994) 6 African Journal of International \& Comparative Law, 429-48.

- "Public Choice Theory and the Failure of the ECOWAS Trade Liberalization Scheme.” (2000) 23:4 World Competition, 137-54.

_. "Sub-State Protectionism in Ghana." (2010) 18 African Journal of International and Comparative Law, 78-91.

- "When Two Leviathans Clash: Free Movement of Persons in ECOWAS and the Ghana Investment Act of 1994.” (2013) 6:1 African Journal of Legal Studies, 116. 
Lancaster, Carol. "ECOWAS: Problems and Prospects," CSIS African Notes, no. 4, 10 October 1982.

Lee, Alexander, and Kenneth A. Schultz. "Comparing British and French Colonial Legacies: A Discontinuity Analysis of Cameroon." (2012) 7 Quarterly Journal of Political Science, 1-46.

Lee, M. "Regionalism in Africa: A Part of Problem or a Part of Solution." (2002) 9:1 Polis/R.C.S.P./C.P.S.R., 3.

Lee, Robert and Ellen Stokes, "Environmental Governance: Reconnecting the Global and Local." (2009) 36:1 Journal of Law and Society, 1-10.

Levitt, Jeremy. "Conflict Prevention, Management, and Resolution: Africa-Regional Strategies for the Prevention of Displacement and Protection of Displaced Persons: The Cases of the OAU, ECOWAS, SADC, and IGAD." (2001) 20:1 Refugee Survey Quarterly, 156-90.

Litowitz, Douglas. "Gramsci, Hegemony, and the Law." (2000) 2000:2 Brigham Young University Law Review.

Lord, Christopher. "Fragmentation, Segmentation and Centre Formation: Some Thoughts on the UK and European Integration from 1950 to Brexit." ARENA Working Paper 3/2017, ARENA Centre for European Studies, 1-20.

Maluwa, Tiyanjana. "Reimagining African Unity: Some Preliminary Reflections on the Constitutive Act of the African Union." (2001) African Yearbook of International Law, 1-38.

Mangu, André Mbata. "The African Union and the Promotion of Democracy and Good Political Governance under the African Peer-Review Mechanism: 10 Years On." (2014) 6:1 African Review, 59-72.

Manirakiza, Pacifique. "Insecurity Implications of Unconstitutional Changes of Government in Africa: From Military to Constitutional Coups." (2016) 17:2 Journal of Military and Strategic Studies, 86-106.

Maxwell O. Chibundu, Maxwell O. "Africa's Economic Reconstruction: On Leapfrogging, Linkages and the Law.” (2003) Third World Legal Studies, 17-41.

Mayeda, Graham. "Appreciate the Difference: The Role of Different Domestic Norms in Law and Development Reform-Lessons from China and Japan.", (2006) 51(3) McGill Law Journal, 547-98. 
—. "Developing Disharmony? The SPS and TBT Agreements and the Impact of Harmonization on Developing Countries." (2004) 7:4 Journal of International Economic Law, 737-64.

- "Investing in Development: The Role of Democracy and Accountability in International Investment Law." (2009) 46:4 Alberta Law Review, 1009-37.

Meagher, K. "A Back Door to Globalization: Structural Adjustment, Globalization and Trans-border Trade in West Africa." (2003) 30:95 Review of African Political Economy, 57-75.

Meagher, Kate. "Throwing out the Baby to Keep the Bathwater: Informal Cross-Border Trade and Regional Integration in West Africa." In Regionalism and Regional Integration in Africa: A Debate of Current Aspects and Issues. Uppsala: Nordiska Afrikainstitutet, 2001, 40-53.

Meernik, James, et al. "The Impact of Human Rights Organizations on Naming and Shaming Campaigns." (2012) 56:2 Journal of Conflict Resolution, 233-56.

Meltzer, Joshua. "State Sovereignty and the Legitimacy of the WTO." (2005) 26:4 University of Pennsylvania Journal of International Economic Law, 693-733.

Millerman, M. (2015) "Theory Talk \#71: John M. Hobson on Eurocentrism, Historical Sociology and the Curious Case of Postcolonialism.", Theory Talks, http://www.theory-talks.org/2015/09/theory-talk-71.html.

Mistry, Percy S. "Africa's Record of Regional Co-operation and Integration.” (2000) 99 African Affairs, 553-73.

Moyn, Samuel. "A Powerless Companion: Human Rights in the Age of Neoliberalism." (2014) 77:4 Law and Contemporary Problems, 147-69.

Naon, Horacio A. Grigera. "Sovereignty and Regionalism." (1995-1996) 27 Law and policy in International Business, 1073-1180.

North, Douglass C. "The New Institutional Economics and Development." (Washington University, St. Louis, n.d.

Nwauche, Enyinna S. "The ECOWAS Community of Justice and the Horizontal Application of Human Rights." (2013) 13 African Human Rights Law Journal, $30-54$.

Nyerere, Julius K. "Non-Alignment in the 1970s." Julius Nyerere, Speeches and Statements.

. "Unity for a New Order." Arusha, Tanzania, 12 February 1979. 
Obuah, Emmanuel. “Book Review,” (2001) 39:1 Journal of Modern African Studies.

Ogbonnaya, Ufiem Maurice, Kanayo Ogujiuba, and Nancy Stiegler. "Terrorism in Nigeria, Implication of Boko Haram's Movement for Security and Stability in the ECOWAS Sub-region.” (2014) 23:2 African Security Review, 145-60.

Ojo, Olatunde J. B. "Nigeria and the Formation of ECOWAS." (1980) 34:4 International Organization, 571-604.

Okolo, Julius Emeka. "Integrative and Cooperative Regionalism: The Economic Community of West African States," (1985) 39:1 International Organization, $121-53$.

Olukoshi, Adebayo. "West Africa's Political Economy in the Next Millennium: Retrospect and Prospect." CODESRIA Monograph Series, 2/2001.

Omorogbe, Yinka. "The Legal Framework for Economic Integration in the ECOWAS Region: An Analysis of the Trade Liberalisation Scheme." (1993) 5 African Journal of International and Comparative Law, 355 at 364-65.

Öniş, Ziya. "The Logic of the Developmental State." (1991) 24:1 Comparative Politics, $109-26$.

Onoria, Henry. "Locus Standi of Individuals and Non State Entities before Regional Economic Integration Bodies in Africa." (2010) 18 African Journal of International and Comparative Law, 143-69.

Oppong, Richard F., "Enforcing Judgments of the SADC Tribunal in the domestic courts of member states" (2010) 10 Monitoring Regional Integration in Southern Africa Yearbook 115-142.

—. "Integration through Law: An Examination of the Jurisprudence of Regional Economic Integration Judicial Bodies in Africa." (2007) Monitoring Regional Integration in Southern Africa Yearbook: Namibian Economic Policy Research Unit, 203-27.

—. "Making Regional Economic Community Laws into Enforceable National Laws-Constitutional and Judicial Challenges." (2008) 8 Monitoring Regional Integration in Southern Africa Yearbook, 149-78.

—. "Review of The Institutional Transformation of the Economic Community of West African States by Kofi Oteng Kufuor." (2008) 16 African Journal of International and Comparative Law, 115-118. 
- "The African Union, The African Economic Community and Africa's Regional Economic Communities: Untangling a Complex Web." (2010) 18 African Journal of International and Comparative Law.

— Courts." (2014) 5 Journal of International Dispute Settlement, 344-71.

Ovrawah, Anuke. "Harmonisation of Laws within the Economic Community of West African States (ECOWAS)." (1994) 6 African Journal of International and Comparative Law. 76.

Özsu, Umut "In the Interests of Mankind as a Whole: Mohammed Bedjaoui's New International Economic Order." (2015) 6:1 Humanity: An International Journal of Human Rights, Humanitarianism, and Development, 129-43.

—. "Neoliberalism and the New International Economic Order: A History of 'Contemporary Legal Thought."' In In Search of Contemporary Legal Thought, edited by Christopher L. Tomlins and Justin Desautels-Stein. Cambridge: Cambridge University Press, 2016.

—. "Rendering Sovereignty Permanent? The Multiple Legacies of the New International Economic Order." (2016) European Yearbook of International Economic Law.

Perry-Kessaris, Amanda. "What Does It Mean to Take a Socio-Legal Approach to International Economic Law?." In Socio-Legal Approaches to International Economic Law: Text, Context, Subtext, edited by Amanda Perry-Kessaris, 3-18. New York: Routledge, 2013.

Prempeh, H. Hwasi. “Africa's 'Constitutionalism Revival': False Start or New Dawn?." (2007) 5:3 International Journal of Constitutional Law, 469-506.

Robson, Peter. "The New Regionalism and Developing Countries." (1993) 31:3 Journal of Common Market Studies, 329-48.

Richard, Joseph. "Democratization in Africa after 1989: Comparative and Theoretical Perspectives." (1997) 29:3 Comparative Politics, 363-82.

Riddell, J. Barry. "Things Fall Apart Again: Structural Adjustment Programmes in SubSaharan Africa." (1992) 30:1 Journal of Modern African Studies, 53-68.

Rittich, Kerry. "The Future of Law and Development: Second-Generation Reforms and the Incorporation of the Social." In The New Law and Economic Development: A Critical Appraisal, edited by David M. Trubek and Alvaro Santos, 203-252. Cambridge: Cambridge University Press, 2006. 
Ruland, Jurgen, and Karsten Bechle, "Defending State-Centric Regionalism through Mimicry and Localization: Regional Parliamentary Bodies in the Association of Southeast Asian Nations (ASEAN) and Mercusor." (2014) 17:1 Journal of International Relations and Development, 61-88.

Salami, Iwa. "Legal and Institutional Challenges of Economic Integration in Africa." (2011) 17:5 European Law Journal, 667.

- and Abdourahmane Idrissa, "Out of the Penkelemes [neologism with English rendering "peculiar mess]: The ECOWAS Project as Transformation." The Global Economic Governance Programme, University of Cambridge, Working Paper Series, August 2013,GEG WP 2013/76.

Sano, Hans-Otto. "Development and Human Rights: The Necessary, but Partial Integration of Human Rights and Development." (2000) 22 Human Rights Quarterly, 734-52.

Schouten, P. "Theory Talk \#15: Peter Katzenstein on anti-Americanism, Analytical Eclecticism and Regional Powers," Theory Talks, 2008, http://www.theorytalks.org/2008/08/theory-talk-15.html.

Sesay, Amadu. "Can ECOWAS Reinvent the Nationalists' Dream? Reflections on the Protocol on Democracy and Good Governance." In The Crisis of the State and Regionalism in West Africa, edited by W. A. Fawole and Charles Ukeje. Dakar: CODESRIA, 2005.

Shagari, Shehu. "Messages from Heads of State or Government." In Regionalism and the New International Economic Order, edited by D. Nicol, L. Echeverria, and A. Peccei, 379-80. Oxford: Pergamon Press, 1981.

Shams, Rasul. "Regional Integration in Developing Countries: Some Lessons Based on Case Studies," Hamburgisches Welt-Wirtschafts-Archiv Discussion Paper 251, Hamburg Institute of International Economics, 1-35.

Shaw, Timothy M., J. Andrew Grant, and Scarlett Cornelissen. "Introduction and Overview: The Study of New Regionalism(s) at the Start of the Second Debate of the Twenty-First Century." In The Ashgate Research Companion to Regionalisms, edited by Timothy M. Shaw, 1-30. New York: Routledge, 2012.

Sloan, John W. "The Strategy of Developmental Regionalism: Benefits, Distribution, Obstacles, and Capabilities." (1971) 10:2 Journal of Common Market Studies, $138-62$.

Söderbaum, Fredrik. "What's Wrong with Regional Integration? The Problem of Eurocentrism." Robert Schuman Centre for Advanced Studies, Global 
Governance Programme-63, RSCAS 2013/64, European University Institute, 115.

. "Early, Old, New and Comparative Regionalism: The Scholarly Development of the Field." Working Paper, KFG The Transformative Power of Europe. No. 64, October 2015.

."Whose Regionalism in Africa?." (2012) 1:9 Great Insights.

- "Comparative Regionalism." In SAGE Handbook of Comparative Politics, edited by Todd Landman and Neil Robinson, London: Sage Books, 2009.

— Gained from Dialogue?.” (2010) 32:6 Journal of European Integration, 563-582.

—, Hanna Skansholm, and Therese Brolin, "From Top-Down to Flexible Cooperation: Rethinking Regional Support for Africa." The Nordic Africa Institute, Policy Note 3, 2016.

—, and Therese Brolin, "Support to Regional Cooperation and Integration in Africa-What Works and Why?.” January 2016.

Swart, Mia. "Can Regional and Sub-Regional African Courts Strengthen the Rule of Law in Africa? Questions of Impact and Enforcement." In Shielding Humanity, edited by Charles Jalloh and Olufemi Elias, 705-25. Leiden: Koninklijke Brill NV, 2015.

Sweberg, R. "The Case for an Economic Sociology of Law." (2003) 32 Theory and Society, 1-37.

Tamanaha, Brian Z. "The Primacy of Society and the Failures of Law and Development." (2011) 44 Cornell International Law Journal, 209-244.

Tan, Celine. "Navigating New Landscapes: Socio-Legal Mapping of Plurality and Power in International Economic Law." In Socio-Legal Approaches to International Economic Law: Text, Context, Subtext, edited by Amanda Perry-Kessaris, 64-76. New York: Routledge, 2013.

Taylor, Ian. "Globalization and Regionalization in Africa: Reactions to Attempts at Neoliberal Regionalism." (2003) 10:2 Review of International Political Economy, 310-30.

Thompson, Bankole. "Legal Problems of Economic Integration in West African Subregion." (1990) 2 African Journal of International and Comparative Law. 792839. 
, and Richard S. Mukisa. "Legal Integration as a Key Component of African Economic Integration: A Study of Potential Legal Obstacles to the Implementation of the Abuja Treaty." (1994) 20 Commonwealth Law Bulletin. 1446.

Tino, Elisa. "The Variable Geometry in the Experience of Regional Organizations in Developing Countries." (2013-2014) 18 Spanish Yearbook of International Law, $141-162$.

Tuck, Christopher. "Every Car or Moving Object Gone: The ECOMOG Intervention in Liberia" (2000) 4:1 African Studies Quarterly, 1-16.

VanDuzer, Anthony. "Canadian Investment Treaties with African Countries: What Do They Tell Us About Investment Treaty Making in Africa?." (2017) 18 Journal of World Investment and Trade, 556-84.

— - Penelope Simons, and Graham Mayeda. "Modelling International Investment Agreements for Economic Development." In Bilateralism and Development: Emerging Trade Patterns, edited by Veniana Qalo, 359-410. London: CameronMay, 2008.

Vayrynen, Raimo. "Regionalism: Old and New." (2003) 5 International Studies Review, $25-51$.

von Staden, Andreas. "Subsidiarity, Exhaustion of Domestic Remedies, and the Margin of Appreciation in the Human Rights Jurisprudence of African Sub-regional Courts." (2016) 20:8 International Journal of Human Rights, 1113-31.

Williamson, Oliver E. "The New Institutional Economics: Taking Stock, Looking Ahead." (2000) 38:3 Journal of Economic Literature, 595-613.

Yang, Yongzheng, and Sanjeev Gupta. "Regional Trade Agreements in Africa: Past Performance and the Way Forward", IMF Working Paper WP/05/36, February 2005, pp. 1-36.

Yansane, A. Y. "West African Economic Integration: Is ECOWAS the Answer?" (1977) 24:3 Africa Today, 43-59.

Young, Crawford. "The Third Wave of Democratization in Africa: Ambiguities and Contradictions." In State, Conflict, and Democracy in Africa, edited by Richard Joseph, 15-38. Boulder, CO: Lynne Rienner, 1999.

\section{UNITED NATIONS ECONOMIC COMMISSION FOR AFRICA REPORTS}

United Nations Economic Commission for Africa, "Appraisal and Review of the Impact of the Lagos Plan of Action on the Development and Expansion of Intra-African 
Trade." UNECA Conference of African Ministers of Trade Meeting (11th session: 15-19 April 1990: Addis Ababa, Ethiopia). Addis Ababa: UNECA.

United Nations Economic Commission for Africa, "Preliminary Draft of a Treaty for the Economic Community of West Africa and Explanatory Notes." E/CN.14/WA/EC/5, (27 October 1967).

United Nations Economic Commission of Africa, "On the General Scheme for Coordinating and Harmonizing Integration Activities in Africa-A Critique of the Principle of Variable Geometry." ECA/UNDP/IGOs/UNSAS/VII/10, January 1993, 1, http://repository.uneca.org/bitstream/handle/10855/14362/Bib55871.pdf? sequence $=1$.

\section{UNITED NATIONS CONFERENCE ON TRADE AND DEVELOPMENT}

United Nations Conference on Trade and Development, "Regional Cooperation and Integration in Sub-Saharan Africa.” Discussion Paper No. 189, September 2008.

United Nations Conference on Trade and Development, Economic Development in Africa Report 2009, "Strengthening Regional Economic Integration for Africa's Development." United Nations, New York and Geneva, 2009.

United Nations Conference on Trade and Development (UNCTAD), Economic Development in Africa Report 2013, Intra-African Trade: Unlocking Private Sector Dynamism. UNCTAD, 2013.

\section{ECOWAS CASES}

Center for Democracy and Development and Center for Defense of Human Rights and Democracy v Mamadou Tandja and the Republic of Niger, 2011 CCJELR 105.

Hadijatou Mani Koraou v Republic of Niger, Judgment No. ECW/CCJ/JUD/06/08. Musa Saidykhan v. Republic of Ghana, Case No. ECW/CCJ/APP/11/07.

Ocean King Nigeria Limited v. Republic of Senegal, Suit No. ECW/CCJ/APP/05/08; Judgment No. ECW/CCJ/JUD/07/1.

Olajide Afolabi v Nigeria, Case No. ECW/CCJ/APP/01/03.

Registered Trustees of the Socio-Economic Rights and Accountability Project (SERAP) v Federal Republic of Nigeria \& Universal Basic Education Commission, Suit No: $\mathrm{ECW} / \mathrm{CCJ} / \mathrm{APP} / 08 / 08$.

Sa'Adatu Umar v Federal Republic of Nigeria; Suit No. ECW/CCJ/APP/12/11; Judgment No. ECW/CCJ/JUD/17/12. 
Tidjani v Nigeria, Case No. ECW/CCJ/APP/01/06.

Ugokwe v Nigeria, Case No. ECW/CCJ/JUD/03/05.

\section{ADVISORY OPINION}

Request for Advisory Opinion by ECOWAS Commission, ECW/CCJ/ADV:OPN/01/05, and $E C W / C C J / A D V: O P N / 01 / 08$.

\section{WEBSITES}

ECOWAS Community Court of Justice, http://www.courtecowas.org/site2012/index.php?option=com content\&view=article\&id= $\underline{2 \& \text { Itemid }=5}$

ECOWAS Parliament, http://www.parl.ecowas.int/index.html

ECOWAS Trade liberalization scheme, http://www.etls.ecowas.int

UEMOA, http://www.uemoa.int/Pages/Home.aspx

\section{REPORTS, WORKING PAPERS \& OTHERS}

Adepoju, Aderanti, Alistair Boulton and Mariah Levin. "Promoting Integration through Mobility: Free movement under ECOWAS." http://www.unhcr.org/49e479c811.pdf.

Anarfi, John, Stephen Kwankye, Ofuso-Mensah Ababio, and Richmond Tiemoko. "Migration from and to Ghana: A Background Paper." December 2003, Working Paper C4, Development Research Centre on Migration, Globalisation \& Poverty, University of Sussex, Brighton.

Asante, S. K. B. "Report on an Advisory Mission on Review of the ECOWAS TreatyRegional Economic Cooperation and Integration Options." ECO/RA/91/1.

Atugbua, Raymond A. "Equality, Non-discrimination and Fair Distribution of the Benefits of Development," in Realizing the Right to Development, Essays in Commemoration of 25 Years of the United Nations Declaration on the Right to Development, 109-116. (United Nations December 2013) http://www.ohchr.org/Documents/Issues/Development/RTDBook/PartIIChapter7. pdf. 
Bore, Linda, and Felix Henkel. "Disturbing a Cosy Balance? The ECOWAS Parliament Rocky Road to Co-Decision." Friedrich Ebert Stiftung International Policy Analysis, January 2015, 1-8. http://library.fes.de/pdf-files/iez/11185.pdf.

Child Rights International Network, "ECOWAS: Landmark Court Decision on Right to Education." 23 November 2009. https://www.crin.org/en/library/newsarchive/ecowas-landmark-court-decision-right-education.

Community Court Press Release, "Legal Year: ECOWAS Court Advocates Effective Implementation of Community Law," Monday 8 October 2012. http://www.courtecowas.org/site2012/index.php?option=com content\&view=arti $\underline{\text { cle\&id=143:legalyearpressconference\&catid=14:pressrelease\&Itemid=36. }}$.

Draper, Peter. "Rethinking the (European) Foundations of Sub-Saharan African Regional Economic Integration: A Political Economy Essay," OECD Development Centre Working Paper No. 293, September 2010. http://www.oecd.org/dev/46013902.pdf.

ECOWAS Parliament Press Release, "Parliamentarians Decry Non-Enforcement of the Community Court Judgments." 20 May 2014. http://www.parl.ecowas.int/documents/session_mai_2014/pr3.pdf.

ECOWAS Vanguard Press Release, "The Current Status, Challenges and Benefits of Implementing the ECOWAS Trade liberalization Scheme.” 4 April 2015, vol. 3, no. 2, (online).

ECOWAS Vanguard Press Release, "The ECOWAS Trade liberalisation Scheme: Genesis, Conditions and Appraisal." January 2013, vol. 2, no. 3, (online).

ECOWAS, "ECOWAS-CET will be implemented as of January 1, 2015." ECOWAS News Release of 10 December 2014. http://www.ecowas.int/ecowas-cet-will-beimplemented-as-of-january-2015/.

Engel, Jakob, and Marie-Agnès Jouanjean, "Political and Economic Constraints to the ECOWAS Regional Economic Integration Process and Opportunities for Donor." Overseas Development Institute, February 2015, 17. https://assets.publishing.service.gov.uk/media/57a08997e5274a31e000017a/Politi cal and Economic Constraints to the ECOWAS.pdf.

European Commission, "The Economic Impact of the West Africa-EU Economic Partnership Agreement.” 1-94, March 2016. https://www.tralac.org/images/docs/9814/the-economic-impact-of-the-westafrica-eu-economic-partnership-agreement-march-2016.pdf.

European Commission, "West Africa." http://ec.europa.eu/trade/policy/countries-andregions/regions/west-africa/. 
European Union, "EU Welcomes Ghana's signing and ratification of the EPA." 5 August 2016. https://eeas.europa.eu/headquarters/headquartershomepage en/7766/EU\%20welcomes\%20Ghana\%27s\%20signing\%20and\%20rat ification $\% 20 \mathrm{of} \% 20$ the $\% 20 \mathrm{EPA}$.

Final Report of the Committee of Eminent Persons for the Review of the ECOWAS Treaty, 9 June 1992, 1-180.

Flemes, Daniel. "Conceptualizing Regional Power in International Relations: Lessons from the South African Case." German Institute of Global and Area Studies Working Papers No. 53, June 2007, 1-59.https://www.gigahamburg.de/de/system/files/publications/wp53 flemes.pdf.

Gabriel Mougani, Gabriel. "Challenges towards Regional Financial Integration and Monetary Coordination in the West African Monetary Zone and the East African Community.” AFDB Regional Integration Policy Paper, No. 3, July 2014.

Global Network, "Economic Partnership Agreements-The Case of Nigeria." 5. http://www.solidar.all2all.org/IMG/pdf/b9 trade unions and ngos response to epa nigeria.pdf.

Gowon, General Dr. Yakubu, Chairman, the Committee of Eminent Persons, letter to Dr. Abass Bundu, the ECOWAS Executive Secretary, 9 June 1992.

GRAIN, “Colonialism's New Clothes: The EU's Economic Partnership Agreements with Africa." 21 August 2017. https://www.grain.org/article/entries/5777-colonialisms-new-clothes-the-eu-s-economic-partnership-agreements-with-africa.

Hadijatou's Case: https://www.unodc.org/res/cld/case-law doc/traffickingpersonscrimetype/ner/2008/h m v republic of niger $\mathrm{html} / \mathrm{Had}$ jjatou Mani v. Republic of Niger Community Court of Justice Unofficial E nglish translation.pdf.

Hänggi, Dr. Heiner. "Interegionalism: Empirical and Theoretical Perspectives." 18 May 2000, paper presented at the Pacific Council on International Policy, Los Angeles. http://www.cap.lmu.de/transatlantic/download/Haenggi.PDF.

Hulse, Merran, Regional Powers, and Leadership in Regional Institutions: Nigeria in ECOWAS and South Africa in SADC, KFG Working Paper Series, No. 76, November 2016, Kolleg-Forschergruppe (KFG) "The Transformative Power of Europe“, Freie Universität Berlin. http://www.polsoz.fuberlin.de/en/v/transformeurope/publications/working paper/wp/wp76/WP $76 \mathrm{Hu}$ lse PRINT.pdf.

Human Rights Watch, "The Regional Crisis and Human Rights Abuses in West Africa." A Briefing Paper to the U.N. Security Council, 20 June 2003. 
https://www.hrw.org/news/2003/06/20/regional-crisis-and-human-rights-abuseswest-africa.

International Federation for Human Rights, Practical Guide: The African Court on Human and peoples' Rights: Towards the African Court of Justice and Human Rights, April 2010.https://www.fidh.org/IMG/pdf/african court guide.pdf.

Jodie Keane, Jodie, Massililiano Cali, and Jane Kennan. "Impediments to Intra-Regional Trade in Sub-Saharan Africa.” Overseas Development Institute, September, 2010. http://www.odi.org/sites/odi.org.uk/files/odi-assets/publications-opinionfiles/7482.pdf.

N'Guessan, M'Gbra. "Technical Discussion Paper on General Energy Access in the ECOWAS Region: Towards Universal Energy Access Particularly in Rural and Peri-Urban Areas of the ECOWAS Region: Approaches, Opportunities and Constraints" Final Report, January 2012. http://www.uncsd2012.org/content/documents/164Consolidated Document Gene ral Energy Access FInal\%20(2).pdf.

Nantulya, Paul. "Lessons from Gambia on Effective Regional Security Cooperation." Africa Center for Strategic Studies, 27 March 2017. http://africacenter.org/spotlight/gambia-regional-security-cooperation/.

National Association of Nigerian Traders (NANTS) Regional Trade Advocacy Series, "Sovereignty, Supra-nationality and Trade: The Case of ECOWAS Laws." Vanguard, vol. 2, no. 4, February 2013.

Nedergaard, Peter. "The Influence of Ordoliberalism in European Integration Processes-A Framework for Ideational Influence with Competition Policy and the Economic and Monetary Policy as Examples.” Munich Personal RePEc Archive Paper No. 52331, December 2013, 1-32.

Ogunkola, Olawale E. "An Empirical Evaluation of Trade Potential in the Economic Community of West African States." African Economic Research Consortium Research Paper 84, November 1998, Nairobi, Kenya. http://dspace.africaportal.org/jspui/bitstream/123456789/32056/1/RP84.pdf?1.

Ouattara, Alassane D. "The Challenges of Globalization for Africa." International Monetary Fund, 21 May 1997. https://www.imf.org/en/News/Articles/2015/09/28/04/53/sp052197.

Page, Sheila. "Developing Countries: Victims or Participants, their Changing Role in International Negotiations." Overseas Development Institute, Globalization and Poverty Programme, 2003. 
Sakyi, Daniel, and Eric Evans Osei Opoku, "Regionalism and Economic Integration in Africa: A Conceptual and Theoretical Perspective." The African Capacity Building Foundation, Occasional Paper No. 22, 2014.

SERAP. "ECOWAS Court to FG: Nigerians have a Legal Right to Education." http://serap-nigeria.org/ecowas-court-to-fg-nigerians-have-a-legal-right-toeducation/.

The African-EU Partnership Project, which has its priority areas as "Democracy, Good Governance and Human Rights." http://www.africa-eupartnership.org/en/priority-areas/democracy-good-governance-and-human-rights.

Williams, Paul D. “A New African Model of Coercion? Assessing the ECOWAS Mission in The Gambia.” International Peace Institute Global Observatory, 16 March 2017. https://theglobalobservatory.org/2017/03/ecowas-gambia-barrow-jammehafrican-union/.

Yabi, Dr Gilles Olakounlé. "The Role of ECOWAS in Managing Political Crisis and Conflict: The Cases of Guinea and Guinea-Bissau.” Friedrich Ebert Stiftung, Peace and Security Series, September 2010. http://library.fes.de/pdffiles/bueros/nigeria/07448.pdf.

\section{NEWSPAPERS}

Ansah, Marian Efe. "Nigeria not Complying with ECOWAS Trade Liberalization Scheme." Monday 7 April, 2015. http://citifmonline.com/2014/04/07/nigeria-notcomplying-with-ecowas-trade-liberalization-scheme-mahama/.

Business Times Nigeria, "Buhari: Why Nigeria is Yet to Sign Economic Partnership Agreement with EU," http://www.businesstimes.com.ng/buhari-why-nigeria-isyet-to-sign-economic-partnership-agreement-with-eu/.

Daily Post, "Nigeria Will Lose \$1.3trn to ECOWAS-EU backed Economic Partnership Agreement-[Manufacturers Association of Nigeria]." 19 September 2016. http://dailypost.ng/2016/09/19/nigeria-will-lose-1-3trn-ecowas-eu-backedeconomic-partnership-agreement-man/.

New York Times, "Nigeria Completes the Second Expulsion of Aliens." 26 May 1985. http://www.nytimes.com/1985/05/26/world/nigeria-completes-the-secondexpulsion-of-aliens.html.

Nnenna, O. "ECOWAS Discusses Nigeria's Reservations on Economic Partnership Agreement." 7 September 2016. https://von.gov.ng/ecowas-discusses-nigeriasreservations-on-economic-partnership-agreement/. 
The Citizen, "ECOWAS Single Monetary Union to Launch by 2020." 17 July 2014. http://www.thenigerianvoice.com/news/153069/1/ecowas-single-monetary-unionto-launch-in-2020.html.

The Woyingi Blogger, "African Women's Lives: Contemporary Slavery in Africa, Slavery in Niger: Hadijatou Mani Koraou." 3 April $2011 \mathrm{https}: / /$ woyingi.wordpress.com/2011/04/03/african-womens-lives-hadijatoumani-koraou/.

\section{UNPUBLISHED THESIS}

Camara, Sekou. "Francophone Regionalism and its Impact on West African Integration." (Florida International University Electronic Theses and Dissertations, 2001).

Gowon, Yakubu. "The Economic Community of West African States: A Study in Political and Economic Integration (PhD thesis, University of Warwick, 1984). 